This file was created by scanning the printed publication.

Text errors identified by the software have been corrected; however, some errors may remain.
United States
(f)

Agriculture

Forest Service

Pacific Northwest

Research Station

General Technical

Report.

PNW-GTR-38

October 1996

(4is)

\title{
Disturbance and Forest Health in Oregon and Washington
}

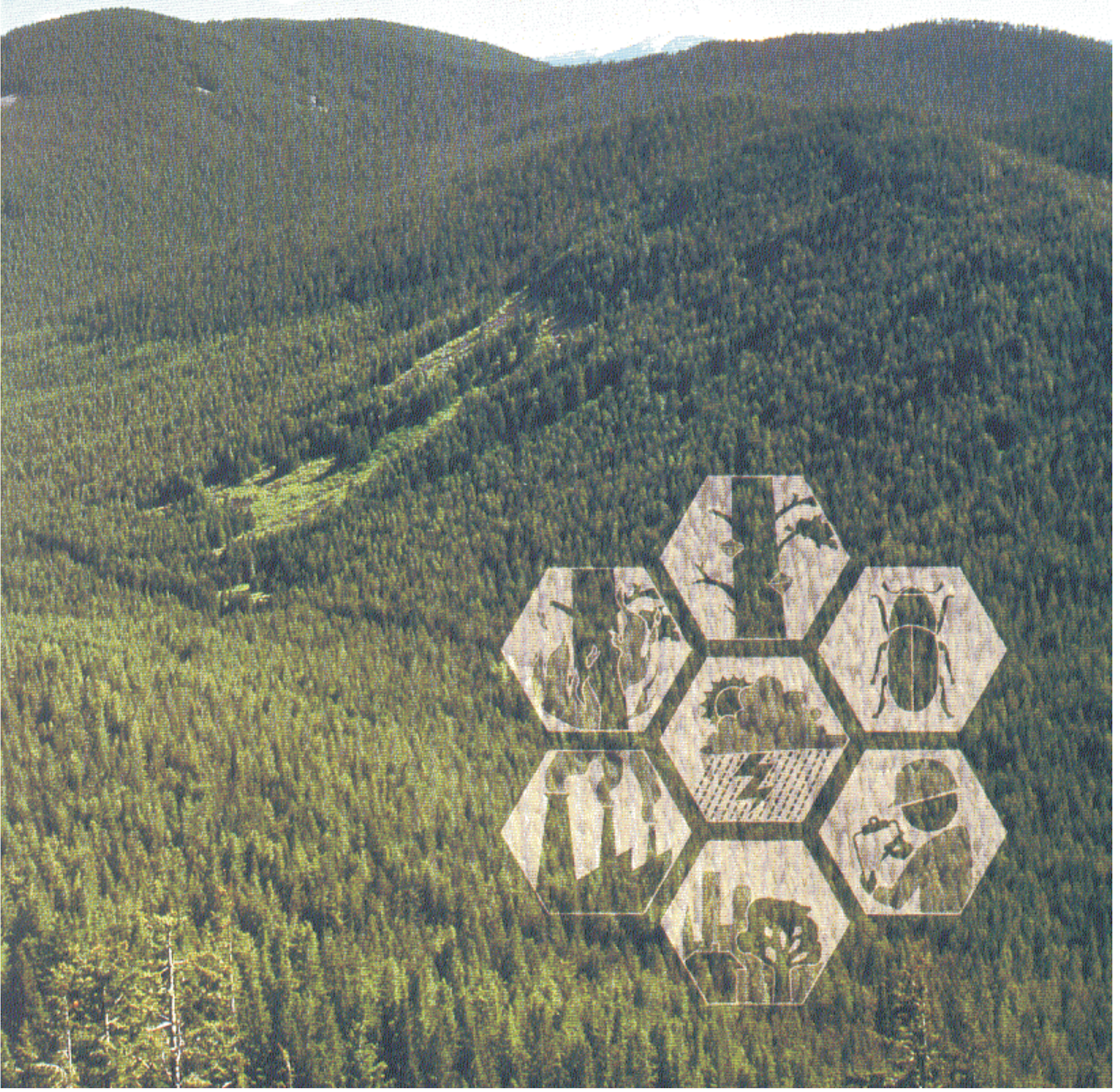


Technical

Coordinators
Sally Campbell is a pathologist, Pacific Northwest Region, PO Box 3623, Portland, OR 97208, and Leon Liegel is a research forester, Pacific Northwest Research Station, 3200 SW Jefferson Way, Corvallis, OR 97331. 


\section{Solutions for Forests East of the Cascades and in Southwest Oregon}

- Thin stands to reduce competition, stress, and bark beetle susceptibility.

- Harvest certain species such as lodgepole pine to create a mosaic of age classes across the landscape to prevent widespread outbreaks of bark beetles.

- Design site-specific regeneration (natural or planted) to promote desired species composition and structure.

- Keep in mind the effects that certain activities (such as thinning, harvest, or re-planting with certain species) will have on root diseases and dwarf mistletoes.

- Reduce forest-floor fuels to prevent destructive, stand replacement fires. Once fuels are reduced, prescribed fire will be safer and more effective.

- Introduce prescribed fire that mimics natural, light ground fires to maintain a light fuel load and remove fire susceptible species such as Douglas-fir and true fir in low elevation pine stands.

- Use fire to regenerate species such as larch or quaking aspen that depend on fire or other disturbance to create appropriate seedbeds or stimulate root sprouting.

\section{Solutions for Forests West of the Cascades}

- In forested areas, shift stands from single species to multiple species to reduce insect outbreaks and proliferation of diseases. Tradeoffs between maximizing timber production (traditionally with even-aged, single species plantations) and minimizing insect and disease damage must be examined.

- Replant harvested or restored areas with seedlings grown from local seed-sources or use natural regeneration. Severity of diseases such as Swiss needle cast is much less when trees are adapted to the site.

- Maintain a mosaic or mix of species and age classes, preventing the whole landscape from being dominated by uniform, highly susceptible stands.

\section{Solutions for Urban Forests}

- Reduce air pollution through a variety of strategies and new technology so that production of ozone and other pollutants that damage forests can be reduced or, at the very least, not increased.

- Maintain programs to monitor and eradicate exotic pests, and to prevent introductions.

- Plant and care for trees and other vegetation in urban areas.

- Manage for hazards such as fire, decay, and root disease in urban-forest interfaces.

\section{The Future}

Citizens, forest owners, and resource managers must all become active to solve forest health problems in Oregon and Washington. Without cooperation and interaction among groups with diverse and opposing viewpoints, future needs and desires for products and services from regional forests will not be met.

East of the Cascades, forest fuel reduction, thinning overstocked stands, and changing species are needed to reduce the risks of uncontrollable, stand-replacing wildfires and widespread insect outbreaks.

West of the Cascades, the continued introduction of exotic insects, diseases, and plants threaten the existence of native forests and, without continual vigilance, chances of establishment and spread are much greater. Air pollution, unless controlled and reduced in the Puget Sound and Willamette Valley, will affect increasing numbers of forest species, influencing their ability to grow and reproduce.

On both sides of the Cascades, the incidence and severity of many native insects and diseases is closely linked to forest management. Awareness of the impact of different management activities on insects and diseases is essential to successfully achieve desired forest conditions.

Forest management, forest health monitoring, research, and public education are the tools needed to create and maintain the forests that are so important to the people of Oregon and Washington. 
DISTURBANCE AND FOREST HEALTH IN OREGON AND WASHINGTON

A joint publication by the USDA Forest Service Pacific Northwest Research Station and Pacific Northwest Region, the Oregon Department of Forestry, and the Washington Department of Natural Resources, 1996.

\section{SUMMARY}

Forest conditions in Oregon and Washington have been steadily changing for more than 100 years. Many disturbance patterns in forest stands no longer occur with the same frequency or intensity as in the past and current patterns are often outside the natural range of variation. Much of the change in disturbance regimes is due to fire suppression, harvesting practices in the last century, and increased urbanization, industry, and commerce.

\section{East of the Cascades}

- Outbreaks of defoliating insects such as western spruce budworm and Douglas-fir tussock moth, are now larger, more intense, and more frequent than in the past.

- Bark beetle mortality, associated with tree stress and overstocked stands, is more prevalent.

- Drought in the late 1980s and early 1990s, coupled with overstocking, contributed to increased susceptibility of forest trees to bark beetles and other insects, fire, and disease.

- Many root diseases and dwarf mistletoes are more widespread and destructive because of past harvest practices and the resulting changes in forest structure and species.

- Fire is less frequent now but more severe on low elevation, dry sites because of fuel buildup.

West of the Cascades

- Incidence and damage by native forest pathogens, particularly root diseases, have increased due to past forest management practices.

- Periods of drought have contributed to susceptibility of trees to attacks by insects and pathogens.

\section{Southwest Oregon}

- The risk of fire and insect outbreaks has increased due to fire suppression, overstocked stands, and periods of drought.

- Two exotic diseases, white pine blister rust and Port-Orford-cedar root disease, have significant affected host species and how they are managed.

\section{Urban Forests}

- Introductions of exotic pests have increased greatly over the past century with increased commerce, travel, and new people moving to the Northwest.

- Air pollution has increased in the Willamette Valley and Puget Sound areas with increased population and industry. Ozone and other pollutants are capable of damaging forests near and far from pollutant sources.

- Stresses on urban trees from air pollution, mechanical injury, and poor maintenance, have increased in many cities and towns.

- Fire, wind, insects, and diseases are hazards to the trees, people, and homes in the urban-forest interface.

\section{Forest Health Monitoring}

- National field protocols for the Forest Health Monitoring Program were tested west of the Cascade crest on 13 plots in Oregon and 12 plots in Washington in 1994 to establish baseline forest conditions in Douglas-fir habitats.

- Operational forest health monitoring across all habitats in Oregon and Washington is scheduled to begin in 1997.

- Other surveys and inventories are on-going and continue to provide information on disturbance agents and forest conditions. 
USDA FOREST SERVICE

Pacific Northwest Research Station

Attn: Forest Health Monitoring

3200 Jefferson Way

Corvallis, OR 97331 


\section{Reader Feedback}

for

"Disturbance and Forest Health in Oregon and Washington"

Your response to the following questions will help us to improve the information we offer.

\begin{tabular}{|ccc|}
\hline & No \\
(o check one) & Yes & No Opinion \\
\hline
\end{tabular}

This report contains the information I (or my organization) $\begin{array}{lll}0 & 0 & 0\end{array}$ needs.

$\begin{array}{llll}\text { This report answers my questions about forest health. } & 0 & 0 & 0\end{array}$

$\begin{array}{llll}\text { The summary section is helpful. } & 0 & 0 & 0\end{array}$

$\begin{array}{llll}\text { The content and organization of the report is clearly } & 0 & 0 & 0\end{array}$ presented.

The graphs and figures are easily understood and contribute to my overall understanding of the issues.

The information in the report is timely to meet my needs $\quad \begin{array}{lll}0 & 0\end{array}$ and answer my questions.

Please circle the answer that best completes the following statements:

This report is (too long / about the right length / too short) to meet my needs.

This report is (too technical / at the right amount of detail / too basic) to meet my needs.

If a similar report is done in the future, I (would / would not) like to receive a copy.

Your state

Your occupation (o check one):

o Scientist / researcher

o State / Federal natural resource

o Teacher / professor

o Land owner specialist

o Student

o Land manager

o Other (describe)

Any other comments for improvements? Other information you would like to see included in future reports? 


\section{Disturbance and Forest Health in Oregon and Washington}

Technical Coordinators:

Sally Campbell USDA Forest Service, PNW Region

Leon Liegel, USDA Forest Service, PNW Research Station Editor:

Martha H. Brookes
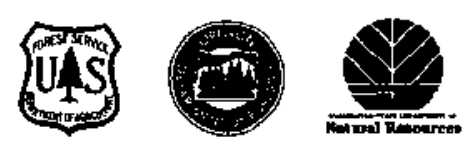

Joint publication of USDA Forest Service, Pacific Northwest Research Station and Pacific Northwest Region; Oregon State Department of Forestry; and Washington State Department of Natural Resources

USDA Forest Service

Pacific Northwest Research Station

Portland, Oregon

General Technical Report PNW-GTR-381

September 1996 
ABSTRACT Campbell, Sally; Liegel, Leon, tech. coords. 1996. Disturbance and forest health in Oregon and Washington. Gen. Tech. Rep. PNW-GTR-381. Portland, OR: U.S. Department of Agriculture, Forest Service, Pacific Northwest Research Station, Pacific Northwest Region; Oregon Department of Forestry; Washington Department of Natural Resources. 105 p.

The scope and intensity of disturbance by such agents as fire, insects, diseases, air pollution, and weather in Pacific Northwest forests suggests that forest health has declined in recent years in many areas. The most significant disturbances and causes of tree mortality or decline in Oregon and Washington are presented and illustrated. We discuss the interrelations of disturbance with forest management activities and the effect on native trees and suggest some solutions for reducing the severity of disturbance. One chapter reports on a forest health monitoring pilot project.

Keywords: Air pollution, diseases, disturbance, fire, forest health monitoring, insects, vegetation change, weather damage. 
Forest Health Monitoring

Solutions for Forests East of the Cascades and in Southwest Oregon

Solutions for Forests West of the Cascades
- National field protocols for the Forest Health Monitoring Program were tested west of the Cascade crest on 13 plots in Oregon and 12 plots in Washington in 1994 to establish baseline forest conditions in Douglas-fir habitats.

- Operational forest health monitoring across all habitats in Oregon and Washington is scheduled to begin in 1997.

- Other surveys and inventories are ongoing and continue to provide information on disturbance agents and forest conditions.

- Thin stands to reduce competition, stress, and bark beetle susceptibility.

- Harvest certain species such as lodgepole pine to create a mosaic of age classes across the landscape to prevent widespread outbreaks of bark beetles.

- Design site-specific regeneration (natural or planted) to promote desired species composition and structure.

- Keep in mind the effects that certain activities (such as thinning, harvest, or replanting with certain species) will have on root diseases and dwarf mistletoes.

- Reduce forest-floor fuel to prevent destructive, stand replacing fires. Once fuels are reduced, prescribed fire will be safer and more effective.

- Introduce prescribed fire that mimics natural, light, ground fires to maintain a light fuel load and remove fire-susceptible species, such as Douglas-fir and true fir, in low-elevation pine stands.

- Use fire to regenerate species such as larch or quaking aspen that depend on fire or other disturbance to create appropriate seedbeds or stimulate root sprouting.

- In forested areas, shift stands from single to multiple species to reduce insect outbreaks and proliferation of diseases. Tradeoffs between maximizing timber production (traditionally with even-aged, single species plantations) and minimizing insect and disease damage must be examined.

- Replant harvested or restored areas with seedlings grown from local seed sources or use natural regeneration. Severity of diseases such as Swiss needle cast is much less when trees are adapted to the site.

- Maintain a mosaic or mix of species and age classes, preventing the whole landscape from being dominated by uniform, highly susceptible stands. 
SUMMARY Forest conditions in Oregon and Washington have been steadily changing for more than 100 years. Many disturbance patterns in forest stands no longer occur with the same frequency or intensity as in the past, and current patterns are often outside the natural range of variation. Much of the change in disturbance regimes is due to fire suppression, harvesting practices in the last century, and increased urbanization, industry, and commerce.

East of the Cascades

- Outbreaks of defoliating insects, such as western spruce budworm and Douglas-fir tussock moth, are now larger, more intense, and more frequent than in the past.

- Bark beetle mortality, associated with tree stress and overstocked stands, is more prevalent.

- Drought periods in the late 1980s and early 1990s, coupled with overstocking, contributed to increased susceptibility to insects, diseases, and fire.

- Many root diseases and dwarf mistletoes are more widespread and destructive because of past harvest practices and the resulting changes in forest structure and tree species.

- Fire is less frequent now but much more devastating on lowelevation, dry sites because of fuel buildup.

West of the Cascades

- Incidence and damage by native forest pathogens, particularly root diseases, have increased because of past forest management practices.

- Periods of drought have contributed to susceptibility of trees to attacks by insects and pathogens.

Southwest Oregon

- The risk of fire and insect outbreaks has increased because of fire suppression, overstocked stands, and periods of drought.

- Two exotic diseases, white pine blister rust and Port-Orfordcedar root disease, have significantly affected their host species and how they are managed.

Urban Forests

- Introductions of exotic pests have increased greatly over the past century with increased commerce, travel, and new people moving to the Northwest.

- Air pollution has increased in the Willamette Valley and Puget Sound areas with increased population and industry. Ozone and other pollutants can damage forests near-and even far from-pollutant sources.

- Stresses on urban trees from air pollution, mechanical injury, and poor maintenance have increased in many cities and towns.

- Fire, wind, insects, and diseases are hazards to the trees, people, and homes in the urban-forest interface. 
- Reduce air pollution through a variety of strategies and new technology so that production of ozone and other pollutants that damage forests can be reduced or, at the very least, not increased.

- Maintain programs to monitor and eradicate exotic pests and to prevent new introductions.

- Plant and care for trees and other vegetation in urban areas.

- Manage for hazards such as fire, decay, and root disease in urban-forest interfaces.

The Future Citizens, forest owners, and resource managers must all become active to solve forest health problems in Oregon and Washington. Without cooperation and interaction among groups with diverse and opposing viewpoints, future needs and desires for products and services from regional forests will not be met.

East of the Cascades, forest fuel reduction, thinning overstocked stands, and changing species are needed to reduce the risks of uncontrollable, stand-replacing wildfires and widespread insect outbreaks.

West of the Cascades, the continued introduction of exotic insects, diseases, and plants threaten the existence of native forests and, without continual vigilance, chances of establishment and spread are much greater. Air pollution, unless controlled and reduced in the Puget Sound area and the Willamette Valley, will affect increasing numbers of forest species, influencing their ability to grow and reproduce.

On both sides of the Cascades, the incidence and severity of many native insects and diseases is closely linked to forest management. Awareness of the effects of different management activities on insects and diseases is essential to achieve desired forest conditions.

Forest management, forest health monitoring, research, and public education are the tools needed to create and maintain the forests that are so important to the people of Oregon and Washington. 


\section{I995 FOREST DISTURBANCE IN OREGON}

Root diseases \& dwarf mistletoes continue to cause subtle but significant mortality and growth losses. Swiss needlc

cast on the coast

is a concern.
Fire suppression contributes to overstocking. species changes and increased risk of disturbance (fire, insects. diseases). Over stocked stands experiencing bark beetle outbreaks.
Western spruce budworm and tussock moth outbreaks collapse throughout state.

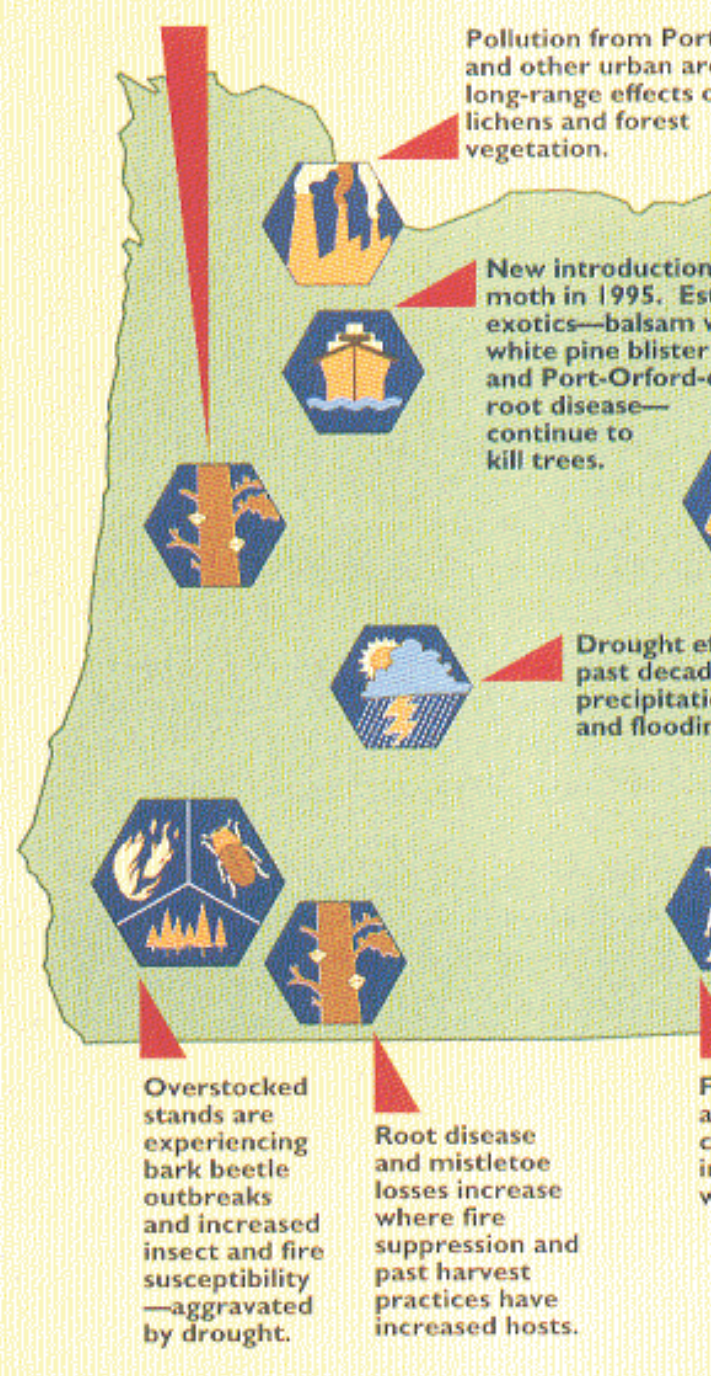

Fir engraver and drought cause mortality in overstocked white fir stands.

Pandora moth outbreak collapses.

rought effects seen from the decade of below-normal recipitation. Winter windstorms

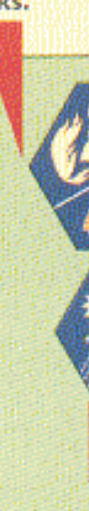

Drought in the late 1980 s and early 1990 s contributes to moisture stress in overstocked stands. 


\section{I995 FOREST DISTURBANCE INWASHINGTON}

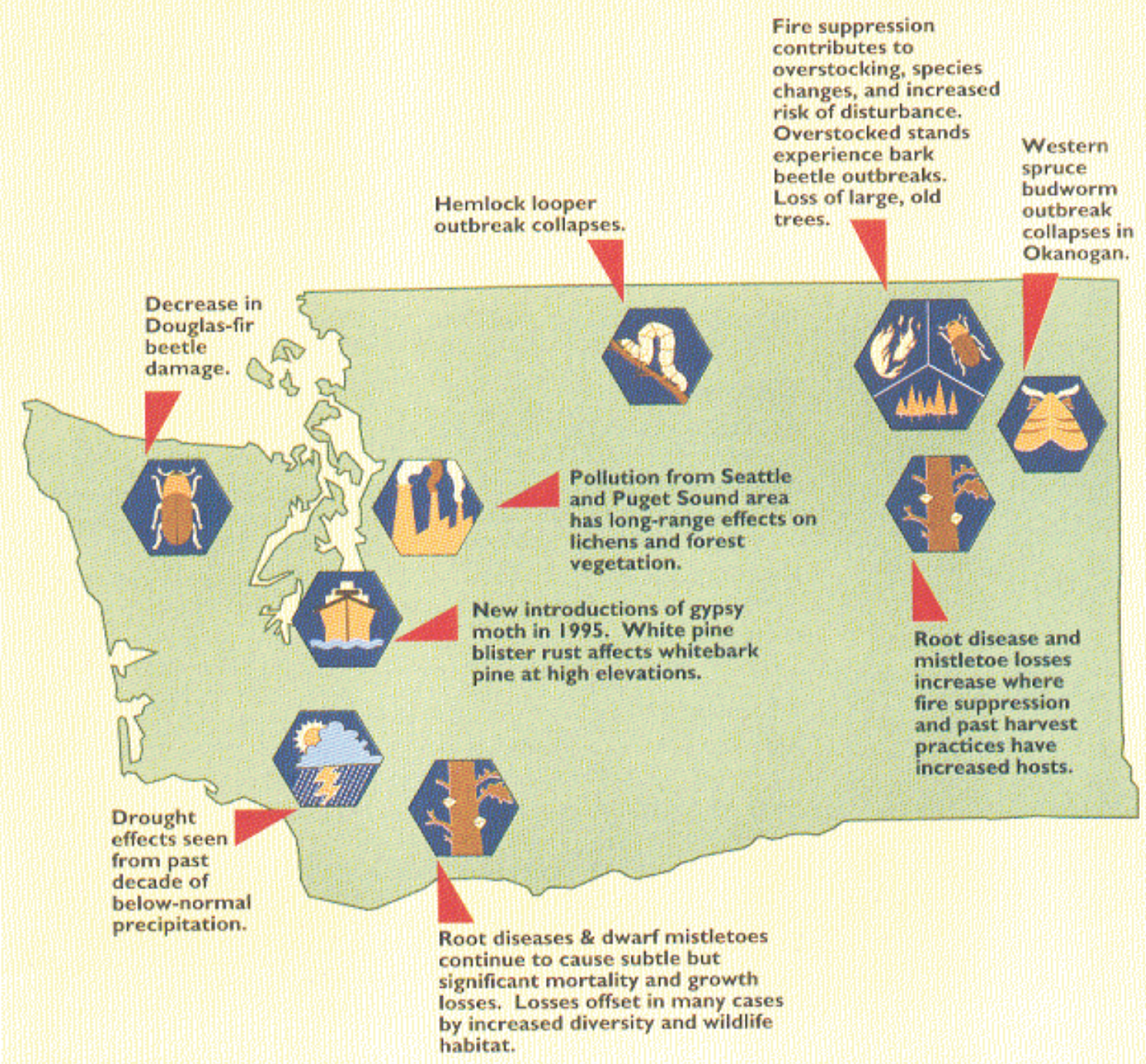


Sally Campbell is a plant pathologist, U.S. Department of Agriculture, Forest Service, Pacific Northwest Region, P.O. Box 3623, Portland, OR 97208.

Karen Ripley is an entomologist, Washington Department of Natural Resources, P.O. Box 47000, Olympia, WA 98504-7037.

Ken Snell is a forester, U.S. Department of Agriculture, Forest Service, Pacific Northwest Region, P.O. Box 3623, Portland, OR 97208.

\section{Chapter 2}

Andy Eglitis is an entomologist, U.S. Department of Agriculture, Forest Service, Pacific Northwest Region, Deschutes National Forest, 1645 Highway 20 East, Bend, OR 97701.

Ellen Goheen is a plant pathologist, U.S. Department of Agriculture, Forest Service, Pacific Northwest Region, J. Herbert Stone Nursery, 2602 Old Stage Road, Central Point, OR 97529.

Alan Kanaskie is a plant pathologist, Oregon State Department of Forestry, 2600 State Street, Salem, OR 97310.

Dave Overhulser is an entomologist, Oregon State Department of Forestry, 2600 State Street, Salem, OR 97310.

\section{Chapter 3}

Robert Backman is an entomologist, Washington Department of Natural Resources, P.O. Box 47000, Olympia, WA 98504-7037.

Jerome Beatty is a plant pathologist, U.S. Department of Agriculture, Forest Service, Pacific Northwest Region, Columbia Gorge Ranger District, 31520 SE Woodard Road, Troutdale, OR 97060.

Karen Ripley is an entomologist, Washington Department of Natural Resources, P.O. Box 47000, Olympia, WA 98504-7037.

Kenhelm Russell is a plant pathologist, Washington Department of Natural Resources, P.O. Box 47000, Olympia, WA 98504-7037.

\section{Chapter 4}

Alan Kanaskie is a plant pathologist, Oregon State Department of Forestry, 2600 State Street, Salem, OR 97310.

Gene Milbrath is a plant pathologist, Oregon State Department of Agriculture, 635 Capitol Street NE, Salem, OR 97310-0110.

Paul Ries is an urban forester, Oregon State Department of Forestry, 2600 State Street, Salem, OR 97310.

\section{Chapter 5}

Leon Liegel is a research forester, U.S. Department of Agriculture, Forest Service, Pacific Northwest Research Station, 3200 Jefferson Way, Corvallis, OR 97331.

\section{Chapter 6}

Sally Campbell is a plant pathologist, U.S. Department of Agriculture, Forest Service, Pacific Northwest Region, P.O. Box 3623, Portland, OR 97208.

LeRoy Kline is an entomologist, Oregon State Department of Forestry, 2600 State Street, Salem, OR 97310. 
ACKNOWLEDGMENTS The following people are gratefully acknowledged for their invaluable contributions to this report.

\section{Layout and Design}

John Me and Delbert Thompson.

Artwork, GIS Products, Photography, and Graphics

Richard Busing, Tom Iraci, Shelley Hayden, Julie Johnson, Russel Mitchell, Mike O'Day, Gail Saunders, Craig Schmitt, Beverly Swanson.

\section{Aerial Survey, Climate, Fire, Insect, and Disease}

\section{Information and Data}

Kathleen Johnson, Craig Schmitt, Don Scott, Keith Sprengel, Dick Stender, Levi Strauss, George Taylor, Mike Ziolko.

\section{Typing and Revising}

Marian Ely and Virginia Hokkanen.

\section{Review of the Draft Report}

Bob Alverts, Bill Burkman, John Dale, Greg Filip, Susan Frankel, Andrew Gillespie, Fred Hall, Jim Hadfield, Robert Mangold, Barbara Ross, Darrell Ross, Susan Sater, Kathy Sheehan, Gordon Schmitt, Dewey Tate. 


\section{CONTENTS}

\section{H A P T E R I AN OVERVIEW OF DISTURBANCE AND FOREST HEALTH IN OREGON AND WASHINGTON Introduction}

Forest Health Defined

What Is at Stake

Assessing Forest Health

This Report

Sources of Information

Scientific References and Names

Changes In Forest Vegetation

Forest Succession

American Indian and Pioneer Influences

Logging and Tree Farming

Fire Suppression

Vegetation, Past and Present

Tree Mortality

Ecological Role of Mortality

Patterns of Mortality

Normal Mortality

Mortality Trends

Weather and Its Influence On Forests

Short-Term Weather Events

Long-Term Weather Changes

The Future

Exotic Pests

Problems With Exotics

Introduction of Exotic Pests

Reducing Introductions

Control and Eradication

Effects of Air Quality

Ozone

Lichens As Bioindicators

Acidity of Cloud Water

Monitoring Methods

Aerial Survey

Forest Inventory

Forest Heath Monitoring Plot Network

New Monitoring Technology

Risk Rating 


\section{$\begin{array}{ll}\text { CHAPTER } 2 & \begin{array}{l}\text { DISTURBANCE AND FOREST } \\ \text { HEALTH IN OREGON }\end{array} \\ 24\end{array}$}

Oregon Coast Range (M242A) and
Western Cascades (M242B)

Ecology 25

All Species $\quad 25$

Douglas-Fir $\quad 26$

Various Species $\quad 29$

Willamette Valley (242A) 30

Ecology $\quad 30$

All Species 30

Oregon White Oak 32

Ponderosa Pine $\quad 32$

Grand Fir $\quad 32$

Hybrid Poplar 32

Eastern Cascades (M242C), Modoc Plateau

(M261G), and Blue Mountains (M332G) 33

Ecology 33

All Species $\quad 33$

Mixed Conifers $\quad 35$

Western Larch $\quad 37$

$\begin{array}{ll}\text { Pines } & 37\end{array}$

Various Species $\quad 38$

Southern Cascades (M261D)

and Klamath Mountains (M26IA) 39

Ecology $\quad 39$

All Species $\quad 39$

Port-Orford-Cedar 41

Five-Needle Pines $\quad 42$

CHAPTER 3 DISTURBANCE AND FOREST

HEALTH IN WASHINGTON 44

Washington Coast Range (M242A), Western

Cascades (M242B), and Puget Trough (242A) 45

Ecology 45

All Species $\quad 46$

Douglas-Fir $\quad 47$

Hemlock 49

True Fir $\quad 50$

Hardwoods $\quad 51$

Eastern Cascades (M242C) 
Ecology 53

Mixed Conifers $\quad 53$

Pines $\quad 56$

Aspen $\quad 58$

CHAPTER 4 DISTURBANCE AND URBAN FOREST HEALTH 60

Introduction 60

Disturbance Agents In Urban Settings 61

CHAPTER 5 FOREST HEALTH MONITORING PILOT

PROJECT IN OREGON AND WASHINGTON 66

General Site and Species Characteristics $\quad 67$

Stand Characteristics 68

Understory Vegetation $\quad 68$

Overstory Vegetation $\quad 68$

Basal Area 69

Crown Ratings $\quad 69$

Sapling Crown Vigor 70

Crown Density 70

Crown Dieback $\quad 71$

Foliage Transparency 71

Damage $\quad 72$

$\begin{array}{lll}\text { Full-Hectare } & \text { Tally } & 73\end{array}$

Vegetation Structure $\quad 74$

Lichen Communities $\quad 75$

Songbird Habitat Indicator $\quad 76$

Conclusions $\quad 77$

$\begin{array}{ll}\text { CHAPTER } 6 & \begin{array}{l}\text { THE FUTURE OF OREGON AND } \\ \text { WASHINGTON FOREST HEALTH }\end{array}\end{array}$

East of the Cascades $\quad 79$

West of the Cascades $\quad 81$

Southwest Oregon $\quad 84$

$\begin{array}{ll}\text { The Future } & 85\end{array}$

SELECTED REFERENCES 87

APPENDICES

Appendix A-Common and Scientific Names $\quad 88$

Appendix B-Counties In

Oregon and Washington $\quad 19$

$\begin{array}{ll}\text { Appendix C-1995 Cooperative } & \\ \text { Aerial Survey Results } & 90\end{array}$

Appendix D-The National Forest
Health Monitoring Program 


\section{CHAPTER I. AN OVERVIEW OF DISTURBANCE AND FOREST HEALTH IN OREGON AND WASHINGTON}

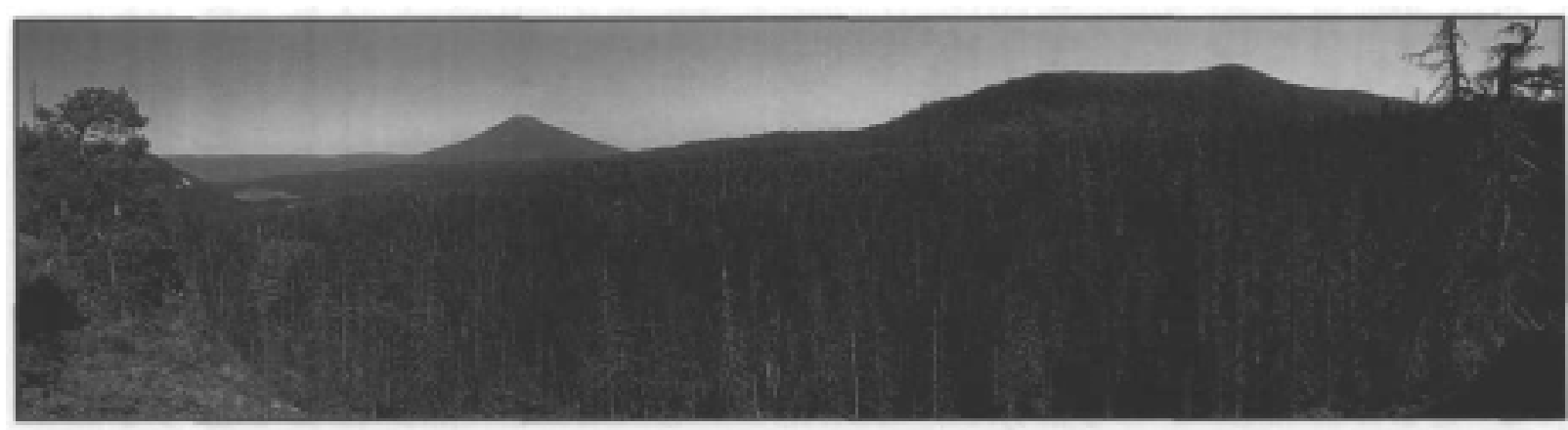

\section{INTRODUCTION}

People, livestock, insects, diseases, snow, wind, fire, volcanic eruptions, earthquakes, and floods are constantly disrupting forests, slowing growth, and injuring or killing trees and other living components of the ecosystem. Disturbance is natural and necessary to forest ecosystems; without it, forests could not regrow, recycle, and pass through successive stages from seedlings to old growth. But, when disturbance causes more continuous, severe, or widespread effects than people consider acceptable or normal, the forest is described as "unhealthy."

\section{Forest Health Defined}

Forest health is a human concept, and people have different views about what constitutes a healthy forest. As demands on forests change over time, so too will people's views of forest health. Currently, two ideas are included in most definitions of forest health.

- A healthy forest maintains its function, diversity, and resiliency; and

- A healthy forest provides for human needs and desires, and looks the way people want it to look.

\section{What Is at Stake?}

More than $36 \%$ of the land area in Oregon and Washington is forested. Forest land in the two states includes more than 18 million acres of federal land (19 National Forests, 7 Indian Reservations, 4 National Parks, and almost 2.5 million acres managed by the Bureau of Land Management), more than 2.8 million acres of state land, and about 16 million acres of private industrial and nonindustrial forest land. The residents of Oregon and Washington depend on these forests for wood products, jobs, fisheries, recreation, scenery, school funding, clean water, and many other products and amenities. Much of what people value about the Pacific Northwest is tied to the forests.

\begin{abstract}
A healthy forest can renewitself vigorously across the landscape, recover from a wide range of disturbances, and retain its ecological resilience while meeting current and future needs of people for values, uses, products, and services. Adapted from: Forest Health Policy, USDA Forest Service, 1996.
\end{abstract}

\section{Assessing Forest Health}

Forest health is assessed by monitoring the condition of various parts of the forest. Certain traits, such as tree growth, crown condition, mortality, and lichen communities, are good indicators of forest health. The condition of these indicators is used to characterize the forest as healthy, unhealthy, or something in between. Over time, monitoring shows changes in forest condition. Forest ecosystems age just as people do, 
so some yearly change is natural. Unexpected and large changes, though, would be cause for concern and lead to further investigations.

Detecting trends in forest condition and predicting long-term consequences of significant changes are the two cornerstones of monitoring activities. By knowing how and when forest conditions will change and what the ulti- mate consequence of these changes might be, scientists, managers, and citizens can work together to plan alternative solutions and actions.

federal and state agencies and private organizations in Oregon and Washington monitor forest health by using a variety of surveys and inventories.
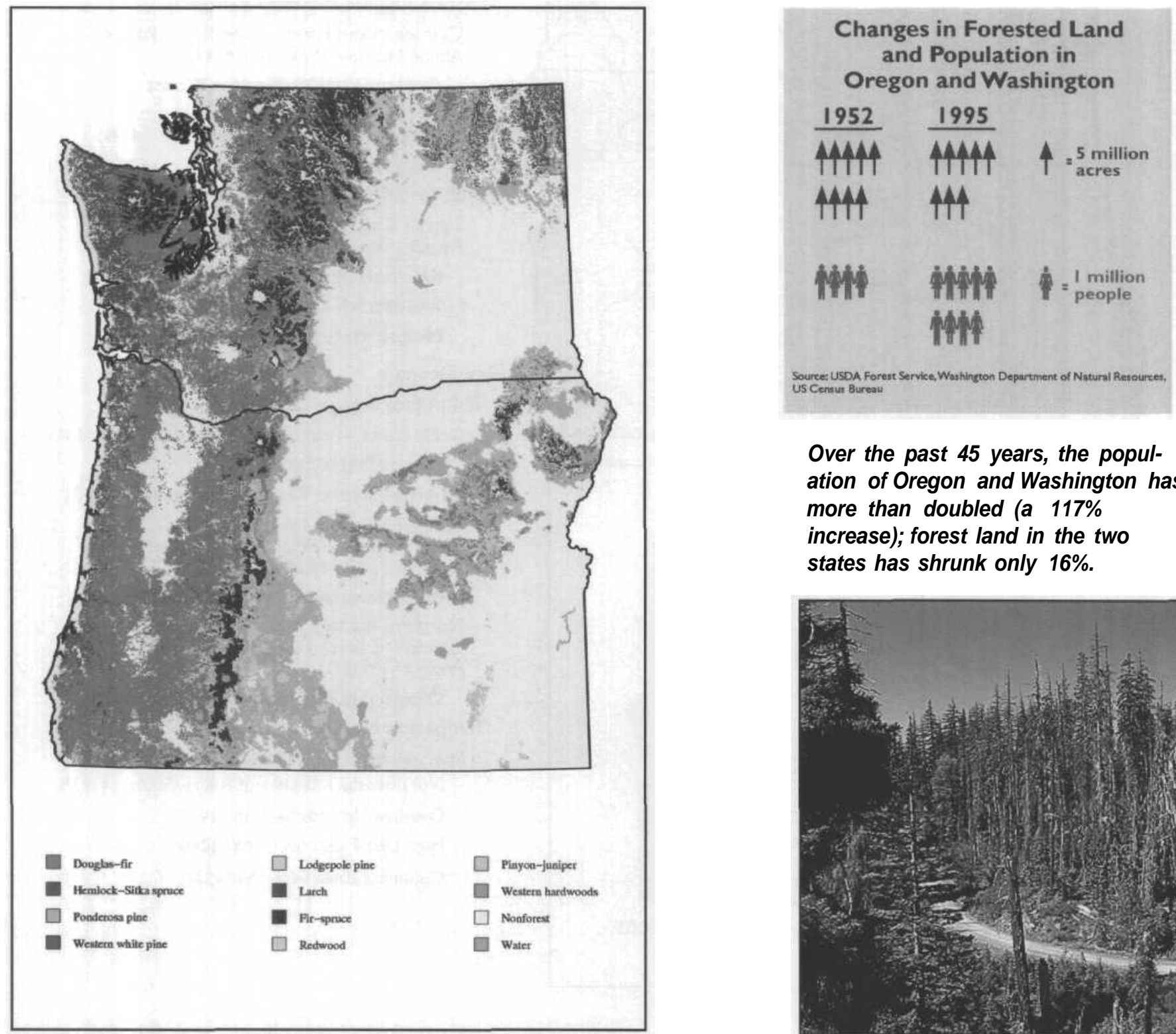

Over the past 45 years, the population of Oregon and Washington has more than doubled (a 117\% increase); forest land in the two states has shrunk only $16 \%$.

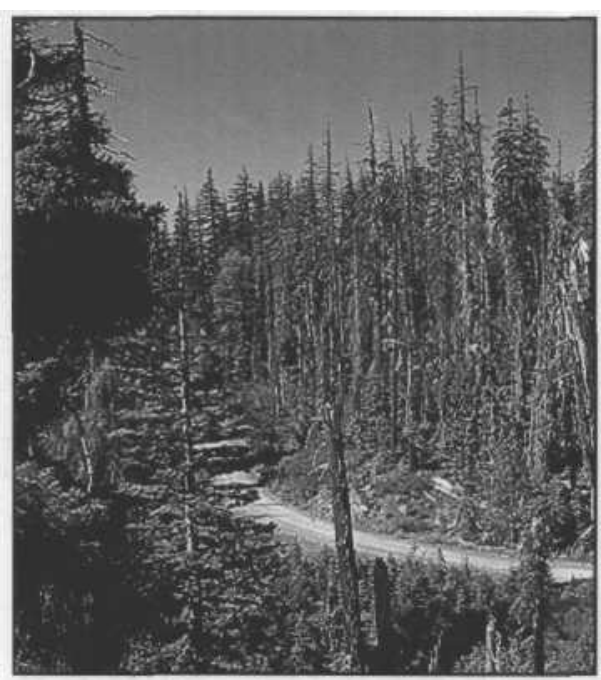

Distribution of forest types in Oregon and Washington.

Source: Southern Forest Research Experimental Station, USDA Forest Service. 

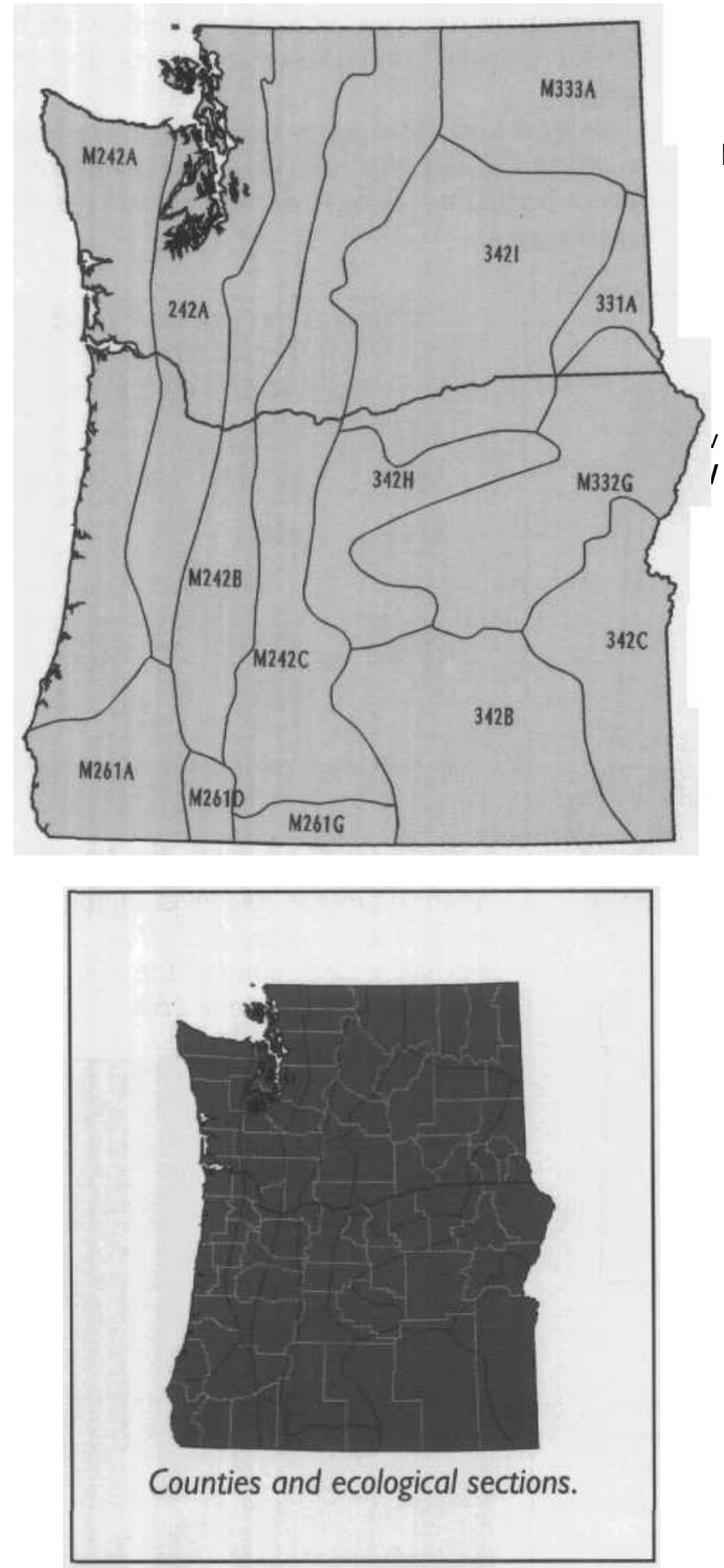

\section{Key}

(sections addressed in this report are in bold):

Humid Temperate Domain

Marine Division (240)

Pacific Lowland Mixed Forest Province (242)

Willamette Valley and

Puget Trough Section(242A)

Marine Regime Mountains (M240)

Cascade Mixed Forest-Coniferous ForestAlpine Meadow Province (M242)

Oregon and Washington Coast

Range Section (M242A)

Western Cascades Section (M242B)

Eastern Cascades Section (M242C)

Mediterranean Regime Mountains (M260)

Sierran Steppe-Mixed Forest-Coniferous Forest-Alpine Meadow Province (M26I)

Klamath Mountains Section (M26IA)

Southern Cascades Section (M26ID)

Modoc Plateau Section (M26IG)

Dry Domain

Temperate Steppe Division (330)

Great Plains-Palouse Dry Steppe Province (331)

Palouse Prairie Section (331 A)

Temperate Steppe Regime Mountains (M33O)

Middle Rocky Mountains Steppe-

Open Woodland-Coniferous ForestAlpine Meadow Province (M332)

Blue Mountains Section (M332G)

Northern Rocky Mountain Forest Steppe

Coniferous Forest-Alpine Meadow

Province (M333)

Okanogan Highlands Section (M333A)

Temperate Desert Division (340) Intermountain Semi-Desert Province (342)

Northwestern Basin and Range Section (342B)

Owyhee Uplands Section (342C)

High Lava Plains Section (342H)

Columbia Basin Section (3431)

Ecological units in Oregon and Washington. Information in chapters 2 and 3 is arranged by ecological Sections. Source: Bailey et al. 1994. 

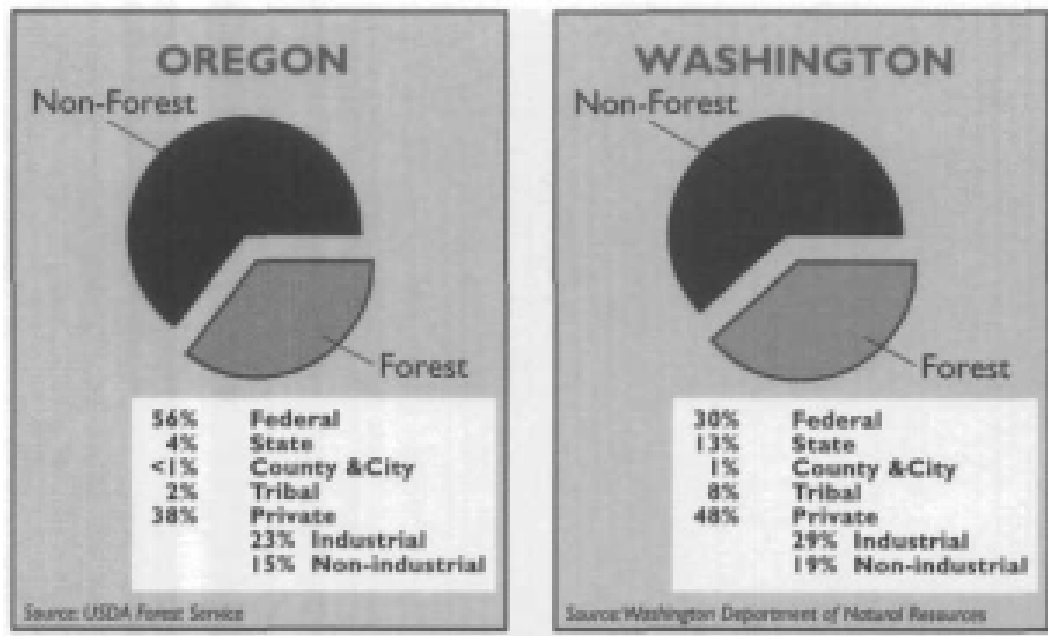

Ownership of forested land in Oregon (left) and Washington (right).

This report was written to help people understand the disturbances at work in the forests of Oregon and Washington, their significance, the underlying causes, and possible actions to improve forest health. The disturbance agents we discuss in the following chapters are insects, diseases, weather, air pollutants, and fire. We also recognize that people are agents of forest disturbance, and the results of people's activities in the forest-such as fire suppression, tree harvest, tree planting, and restoration work-are woven into our discussions as well.

Chapter 1 is devoted to some forest health topics that people in both states are concerned about: vegetation change, mortality, weather trends, exotic pests, and air pollution. We also include a section on forest health monitoring methods.

The next two chapters contain information specific to each state (chapter 2, Oregon; chapter 3, Washington). Information in these chapters is arranged by ecological sections because disturbance agents and patterns are generally tied to the geography, climate, and vegetation that make up an ecological section. We also show which counties correspond to the ecological section being discussed.

Chapter 4 describes disturbance agents and their effects on the health of urban forests in Oregon and Washington. Chapter 5 describes a forest health monitoring research project carried out in the Pacific Northwest in 1994. And chapter 6 is a summary of the disturbances at work in Pacific Northwest forests, our expectations of future disturbances and forest condition, and some strategies for improving forest health in Oregon and Washington.

\section{Sources of Information}

The primary sources of data for insects and diseases in this report are the cooperative (Forest Service and states) aerial survey, flown over all forested lands in Oregon and Washington each year; special aerial surveys for specific problems; various ground surveys; and forest insect and disease research. Information on fire, weather, and air quality came from specialists in the Forest Service and state agencies who, in turn, obtained their data from regional monitoring networks for those resources. Much of the information on ecological relations between trees and disturbance agents is based on the field experience of the pathologists, entomologists, ecologists, and fire and air specialists who contributed to this report.

\section{References and Scientific Names}

To enhance readability, we have not cited references or included scientific names of trees, insects, and fungi in the text. Selected references are listed at the end of chapter 6. Scientific names are listed in appendix A, alphabetically by common name. 


\section{CHANGES IN FOREST VEGETATION}

The amount, variety, age, and size mix of trees on a site determine the extent and severity of damage by disturbance agents. Changes in forest vegetation affect forest health.

Thirteen thousand years ago, glaciers still covered much of North America. As the continent warmed, about 10,000 years ago, glaciers receded and coniferous forests expanded their range. Fossils from Mount Rainier suggest that the period from 6,000 to 3,400 years ago was actually warmer and drier than the current climate.

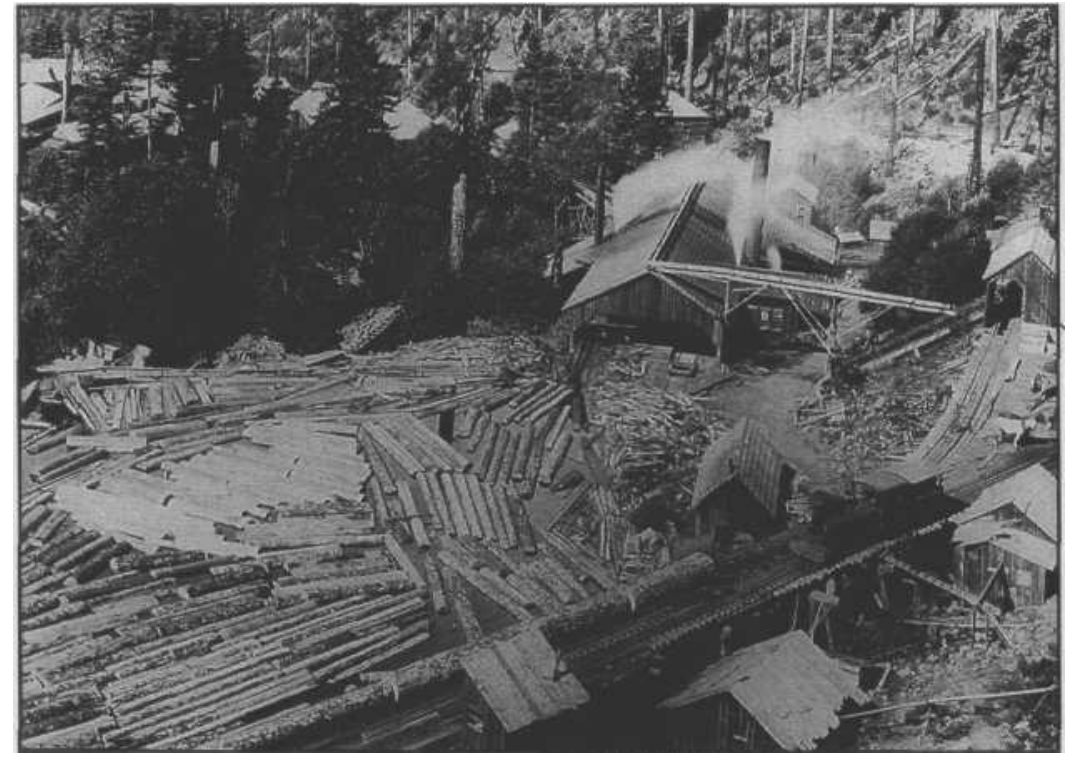

Millions of logs were moving out of the Northwest by the turn of the Century. Photo courtesy of Oregon Historical Society (neg. 45791).

Subalpine fir, Douglas-fir, ponderosa pine, noble fir, and lodgepole pine were common. California chaparral vegetation extended as far north as Vancouver Island. Fires were probably very frequent. The current cooler, wetter period began about 3,500 years ago, and fire frequency declined.

\section{Forest Succession}

Forest succession is the change in species composition as plants grow, die, and are replaced over time. A tree that thrives in a sunny opening created by fire may not be able to reproduce in the shady environment of a mature forest. It will be replaced by a more shade-tolerant species. In the absence of disturbances that create openings, shadetolerant climax species eventually dominate. Type, diversity, and frequency of disturbances interact with site factors such as soil type, topography, weather, climate, and surrounding vegetation to influence which plants invade a site after disturbance and how communities develop. People can affect plant succession by altering the type, severity, and frequency of disturbances.
American Indian and Pioneer Influences

Native people modified the vegetation of the Pacific Northwest - both accidentally and deliberately. Fires set on sites such as Puget Sound's Whidbey Island, the Willamette Valley, and the eastern slopes of the Cascade Range enhanced the growing of bracken, camas, huckleberries, blueberries, and grouseberry and attracted browsing animals like deer and elk.

Early non-native visitors and settlers also modified the forest environment in Oregon and Washington. In many places, the virtual elimination of beaver by trapping for their pelts drastically altered riparian systems. Settlers copied the American Indians' technique of attracting grazing animals by setting many, sometimes devastating fires. Settlers also brought new species to the area: sheep, cattle, cheat grass, wheat, potatoes. Use of forests was initially limited to local demands for construction materials, firewood, and fencing. Some forest lands were converted to agriculture, town sites, and residential areas so, in some places, forest depletion became an issue. 


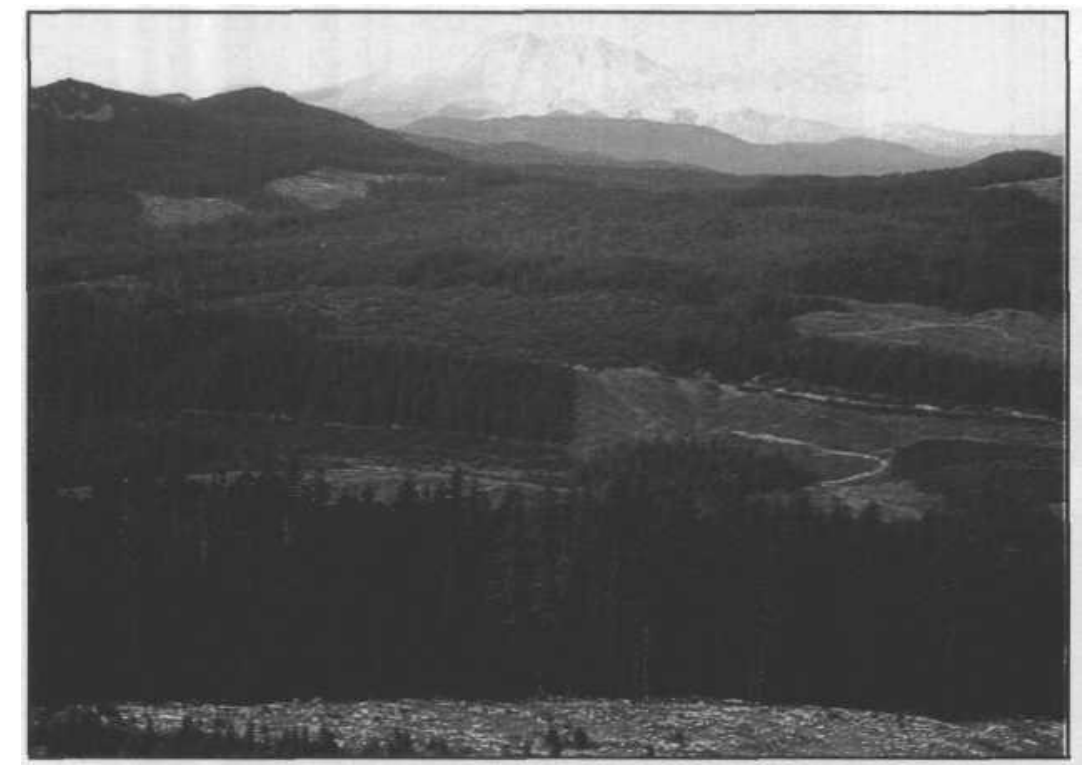

Clearcutting and replanting Douglas-fir from the 1940s through the 1970 s created the mosaic of even-aged, single-species plantations visible today in much of western Oregon and Washington.

Logging and Tree Farming

Logging in the Pacific Northwest created many changes in forest vegetation both east and west of the Cascade crest. The forest industry gained momentum in Washington and Oregon in the late 1800s. The Puget Sound area had major shipping ports. Lumber was sent to San Francisco and helped build many West Coast cities. Logs were dragged out of the woods by oxen, horses, and mules and floated to steam-powered mills. By the turn of the century, narrowgauge railways provided access to remote, rugged areas. Steam-donkey engines on skids and high-lead cables pulling logs above the forest floor made log removal easier and reduced soil compaction. Railroads allowed efficient transport of material to markets in the East, where ponderosa pine and western white pine from eastern Washington and Oregon were highly prized. Low shipping rates allowed Puget Sound producers to compete for interior markets, as well as continue to supply worldwide customers.
Beginning in the early 1900s, mechanized equipment was used extensively. From about 1910 to 1940, the lumber market was glutted. Land owners suffering major economic hardships during this period were forced to liquidate stumpage to pay for the land or other investments. They extracted only the most valuable logs as quickly as possible, leaving "weed" trees standing and high volumes of fuels lying on the ground. Sparks from steam engines and railroads started many fires, and burns through logging debris were hot and damaged the soil, seedlings, and remaining trees.

After World War II, the logging industry struggled to keep up with demand for wood products. Gas-powered chain saws and diesel and gasoline-powered trucks and tractors improved logging efficiency and reduced fire hazard. Removal of all wood within reach of cable settings (clearcutting) increased because of operational efficiency and ease of regenerating new forest in the Douglas-fir region. Slash burning was standard.

By the 1950 s, the most productive portions of Pacific Northwest forests were being managed to maximize timber production. When cutover sites were replanted, Douglasfir was usually the only species planted on the west side and ponderosa pine on the east side. Although the prevalence and distribution of species changed somewhat after logging and replanting, the planted seedlings did not always thrive, and native species often partly or completely revegetated harvested areas. 


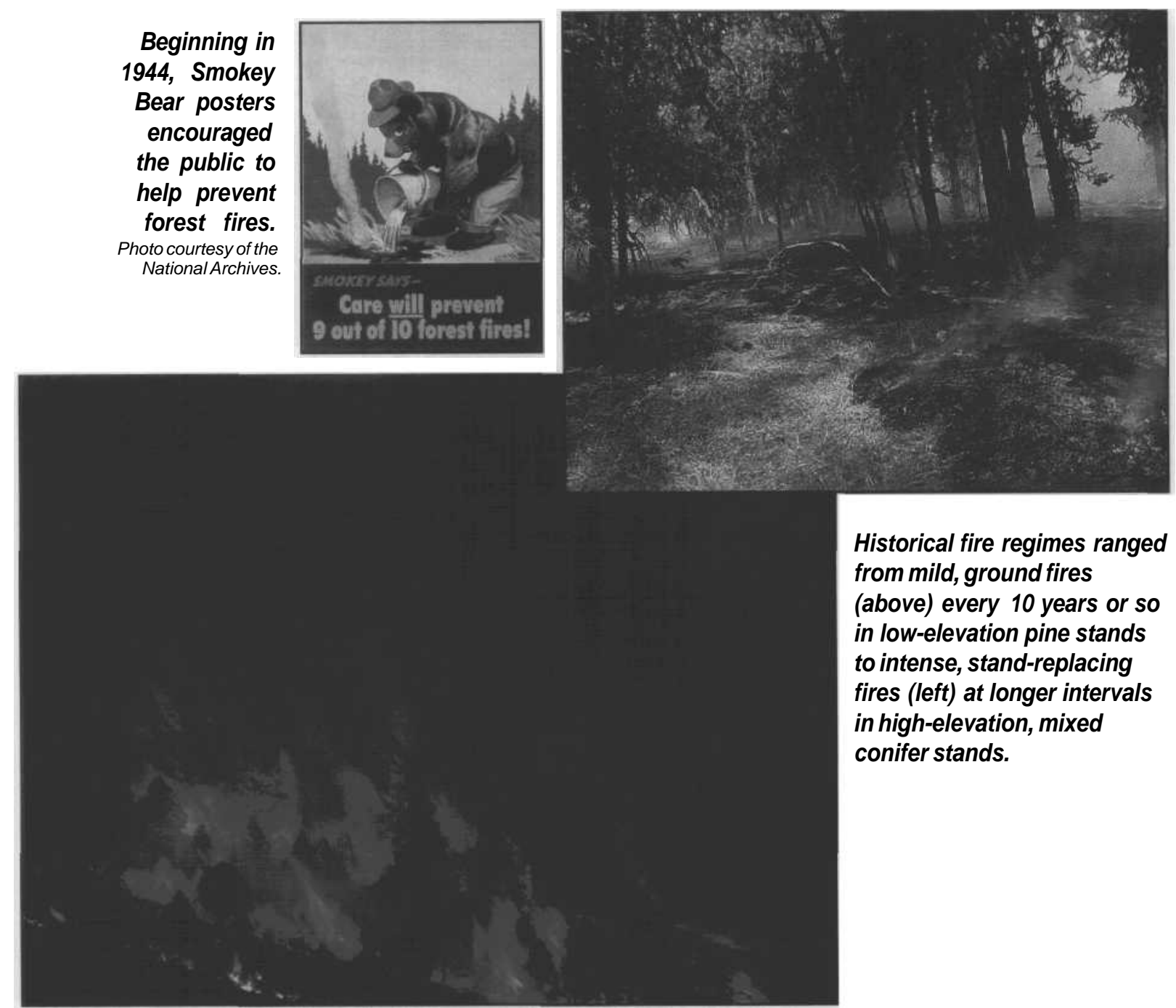

\section{Fire Suppression}

Fire fighting gained momentum after huge fires at the turn of the century. For example, the Yacolt fire in 1902 burned nearly 239,000 acres in Clark and Skamania counties (Washington) and killed 38 people. Several fires, including the Columbia fire near Mount Hood, burned more than 170,000 acres in Oregon the same year.

Society demanded that the forests be protected. Laws regulating slash and slashburning to protect forests were passed in 1911. Permits were required for burning slash in summer, and all snags over 25 feet had to be cut. A highly efficient and coordi- nated forest fire-fighting force was developed nationwide to aggressively attack and quickly control all wildfires. Fire-fighting efficiency increased dramatically after World War II when airplanes became available for detecting and suppressing fires. Campaigns such as "Smokey Bear" encouraged all citizens to help prevent forest fires.

\section{Vegetation, Past and Present}

Today's forests are different in composition and structure from the presettlement period. Pacific Northwest forests have always been affected by disturbances (such as fires, wind storms, volcanic eruptions, and 

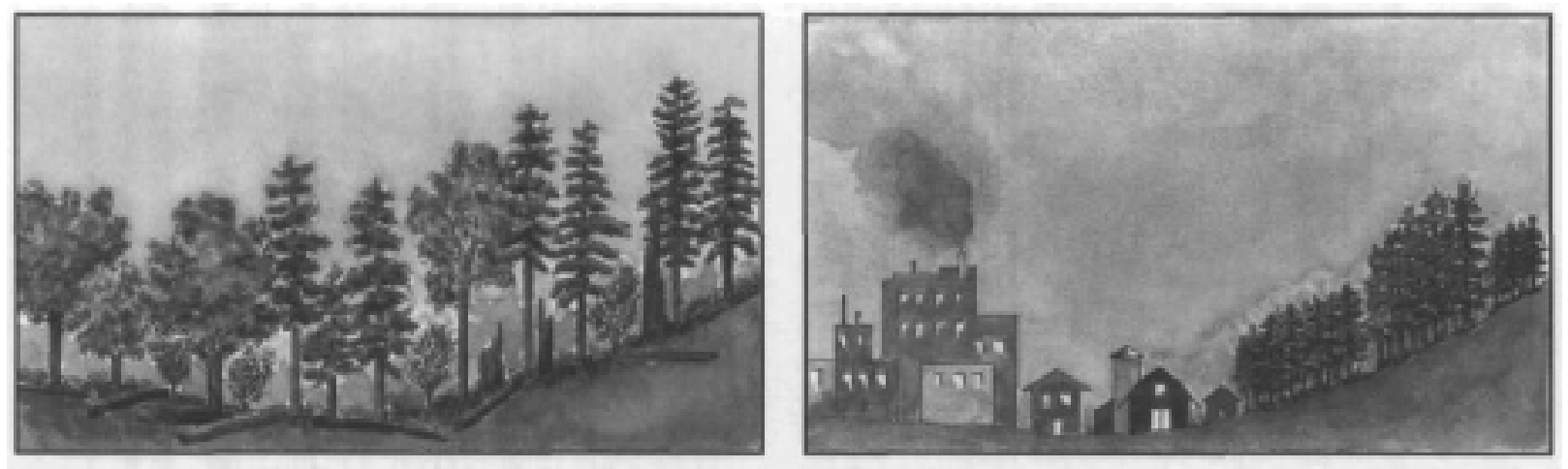

Vegetation change west of the Cascades. Western Oregon and Washington have had large changes in forest vegetation over the past century, before European settlement (left), trees and tree species were more numerous; valleys contained many hardwoods; snags were common; and abundant woody material contributed to periodic widespread fires. In the last 100 years (right), much of the forest in the Puget Sound area and Willamette Valley has been converted to cities, suburbs, and farms; on slopes and mountains of the Coast and Cascade ranges, many forests are younger, less diverse, and more fragmented as the result of years of timber harvesting and replanting. Artwork by Bevely Swanson.

landslides). Disturbances west of the Cascades-predominantly wind storms and wildfire - rarely removed all large woody debris. Fires usually burned during periods of extremely dry weather, and generally several fires were required to consume the wood. Snags, large trees, and unburned patches survived. Wide age ranges in natural Douglas-fir forests suggest slow recolonization because seed sources were absent after large disturbances.

The activities of the increasingly intensified timber industry also disturbed the forests, but they did not mimic the natural disturbances. Today's commercial forests are younger, artificially dominated by even-aged Douglas-fir, have few snags and logs, and are more fragmented than less intensively managed forests or wilderness. Erosion and soil loss are chronic problems associated with roads and annual logging operations rather than periodic problems associated with natural fires.

East of the Cascades, disturbances ranged from frequent, mild, ground fires at low elevations to occasional, intense, stand-replacing fires at high elevations. The suppression of fire took away an important natural means for removing fuels and thinning stands, leaving sites dense with tree cover, particularly at low elevations. Fire suppression and the selective harvest of large pines transformed many open, parklike stands dominated by large pines, into dense, overcrowded stands of predominantly Douglas-fir and grand fir. Riparian areas were altered by grazing and loss of beaver and pool-stabilizing logs. Grazing also affected fire intensity and frequency and, as a result, understory species and stocking. High-elevation forests with longer natural fire frequencies have been less affected by fire suppression than were stands at low elevations.

The forested area in Oregon and Washington faces increasing pressure from human populations. Road building, urban development, agriculture, power lines, and reservoirs have all taken their toll on forested acres. At the same time as worldwide demand for forest products is increasing, demand for beautiful tree-covered recreation and home sites is also rising. Conflicting management objectives for wood products, attractive living spaces, and forested recreation sites will require resolution or compromise.

The ecological effects of these forest changes are reflected in changes in the disturbances that forests experience. Hemlock 

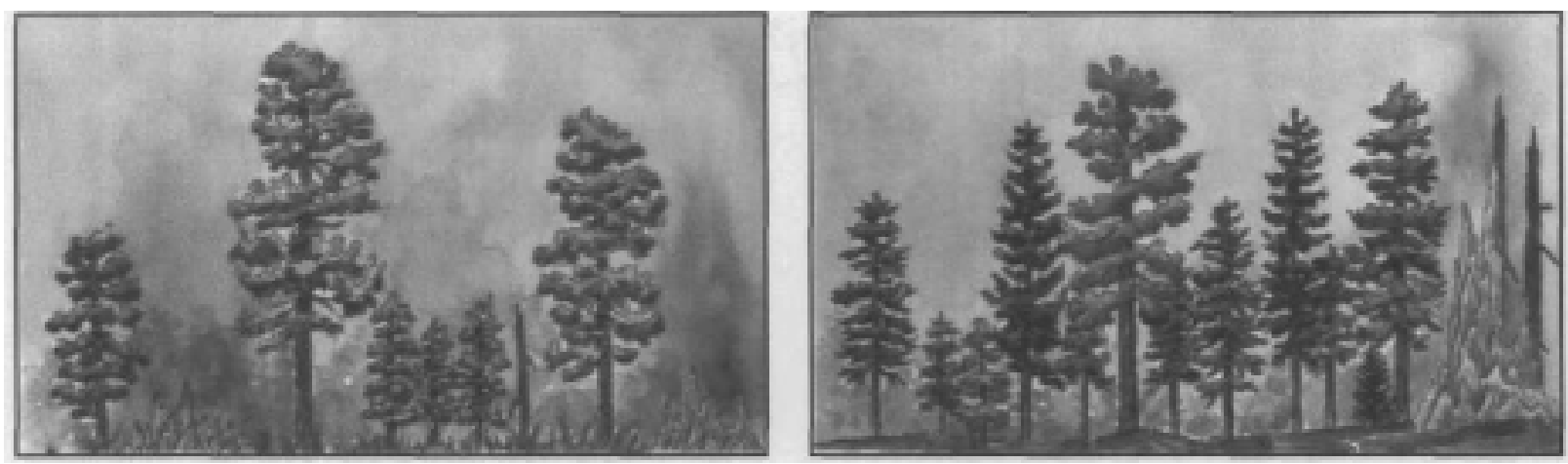

Vegetation change east of the Cascades in Ponderosa pine forests. At lower elevations in eastern Oregon and Washington, open, parklike stands of Ponderosa pine were common before 1900 (left). Frequent, low-intensity fires kept fuels low and killed most seedlings and thin-barked firs, allowing the pine to grow large and dominate. Fire suppression over the last 50 years changed these stands to dense mixtures of Ponderosa pine, Douglas-fir, and true fir (right). Plant and animal diversity increased. Fires are now infrequent and more severe. Changes in species and over-crowding have increased susceptibility of these stands to bark beetles and defoliating insects.

Artwork by Beverly Swanson.
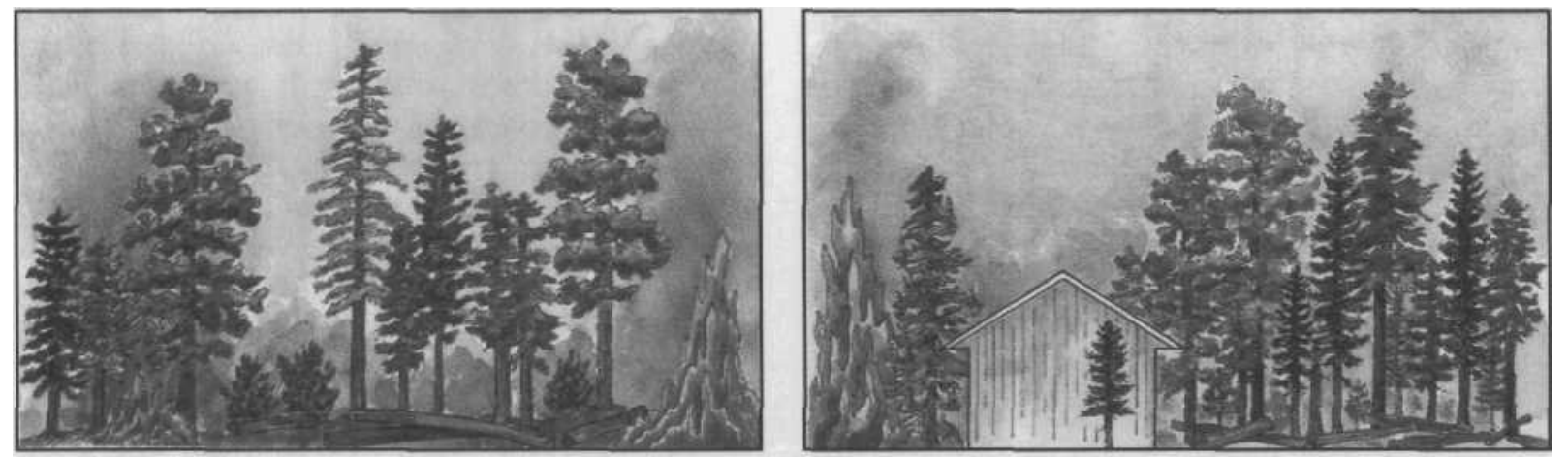

Vegetation change east of the Cascades in mixed conifer forests. Mixed stands of Douglas-fir; true fir; Ponderosa, lodgepole, and white pines; and western larch are common in eastern Oregon and Washington, particularly at middle and high elevations. Before the turn of the century (left), disturbance by fire, insects, and disease was variable, creating mosaics of forest and openings. Fire suppression over the last 50 years has led to increased forest density with more fuels, insect outbreaks, and diseases (right). Fires are now more intense and destructive; homes built in or near forests are at increased risk. Artwork by Beverly Swenson

looper, a pest of old-growth hemlock stands that once killed trees on huge tracts of forest, now has much less host material available and is much less damaging. Injury to dense young trees caused by bear and bark beetles is increasingly common. On sites once dominated by pine, outbreaks of insects that consume Douglas-fir and true fir foliage, and damage by root diseases and dwarf mistletoes have increased in frequency and severity. In some areas, fires are much more devastating than before because of high fuel loads. 


\section{TREE MORTALITY \\ One obvious indicator of potential poor forest health is conspicuous numbers of dead and dying trees.}

Death of trees is normal, but the causes and patterns of mortality are complex. Insects, diseases, drought, wind storms, and fire have killed trees throughout millennia. More recently, other agents associated with people and their industry-air pollution, human-caused fire, and forest management activities-are contributing to tree mortality. Factors such as competition with other trees or plants or being eaten by grazing animals like deer and elk can also cause tree death. Often, death is the result of a combination of causes. For example, competition and drought may stress a tree to such an extent that insects can attack and kill it.

\section{Ecological Role of Mortality}

Death of forest organisms is a necessary part of every forest ecosystem and part of the normal cycling of materials and processes. Tree death contributes woody material to the forest floor where it serves as moisture reservoirs and as habitat for a variety of plants, animals, and microorganisms. The wood and foliage eventually decompose, returning nutrients to the soil. Standing dead trees provide shelter, nesting, roosting, and hunting spots for birds and other animals. Trees that fall in or near streams give the stream the structure it needs to support fish and other aquatic organisms. Tree death creates an ever-changing mosaic of habitats within a forest, allowing light to reach the forest floor, seeds to germinate, and new vegetation to grow.

\section{Patterns of Mortality}

Patterns of mortality are complex. The distribution of mortality from disturbances is determined by patterns of vegetation, the type of disturbance agent, and the physical environment. Where species and structure are similar over a large contiguous area, larger and more severe corresponding disturbances are more likely. Where the forest is less uniform, mortality is patchy and tends to correspond to groups of susceptible species, ages, and structures.

Some disturbances cause widespread mortality in stands of uniform species and age, such as mountain pine beetle in even-aged lodgepole pine. Other disturbance agents, like dwarf mistletoe and western spruce budworm, are favored by multistoried stands where seeds and larvae can drop from tall to short trees. Fire is more deadly in multistoried stands where the understory acts as a fuel ladder, allowing the fire to reach the tree tops.

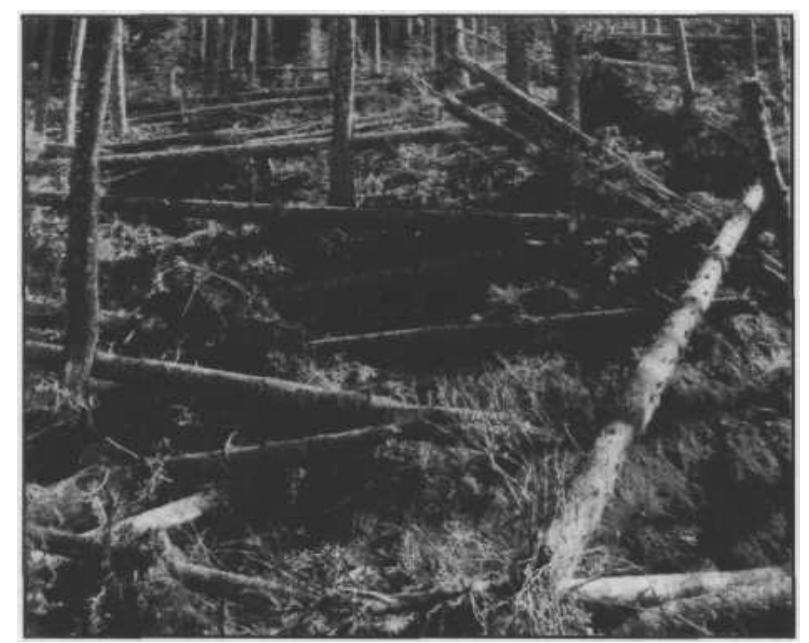

Wind storms, like those in Oregon in winter 1995, blow trees down and snap off tops and branches. Mortality is severe in relatively small areas and often scattered. 


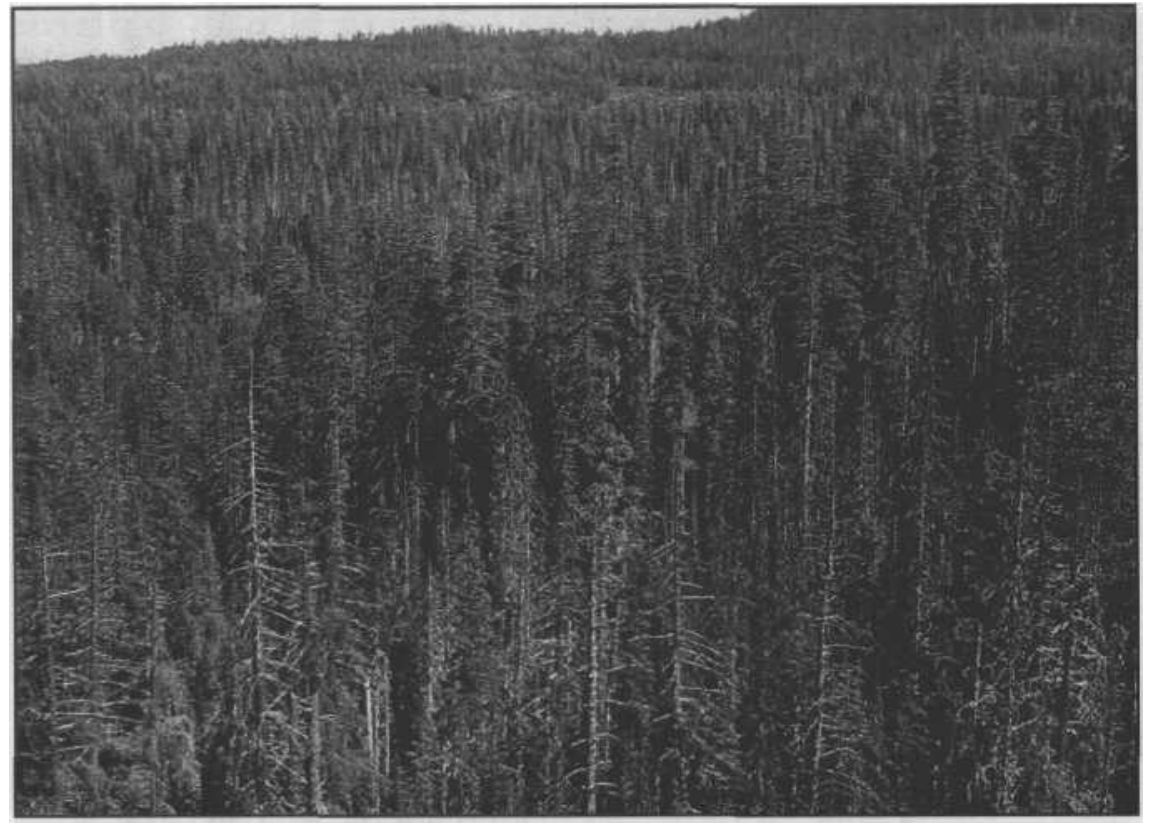

Many places in eastern Oregon and Washington have dense secondgrowth ponderosa pine stands that replaced open, parklike stands of old-growth ponderosa because of fire suppression. These overstocked stands are extremely susceptible to attack by bark beetles. The number of stands in this condition and the resulting mortality is higher than in the past.

Fire frequency and severity have changed significantly over the past century as a result of fire

Insect outbreaks can kill millions of trees, particularly when susceptible suppression practices trees are grouped together, giving the insect an unbroken source of food and increases in tree and breeding habitat

\section{Normal Mortality}

Many scientists and forest managers use historical conditions (from 1600 to 1850 , before European settlement of the West) as the yardstick for determining "normal" conditions. Old journals, photographs, maps, and tree-ring analysis can be used to trace and compare historical forest composition, distribution, and disturbances with current conditions and disturbances. Such analyses have shown that disturbance patterns and mortality are outside the historical range of variability in some areas of Oregon and Washington.

For example, western spruce budworm outbreaks in northeastern Oregon are more frequent and severe now (some stands have more than $80 \%$ overstory mortality) than they were in the 1800s, largely as a result of the selective harvest of nonhost species (ponderosa pine and western larch) and fire suppression. These two practices have led to dense, multistoried stands of predominantly budworm-susceptible species (true fir and Douglas-fir). densities and flammable materials. When fires occur, they are much more severe and kill more trees on each burned acre.

\section{Mortality Trends}

Recent trends in mortality can be tracked through forest inventories or surveys. Most survey and inventory data are relatively recent. The first aerial insect surveys began in the 1940s, and the first forest inventories began in the 1930s. Comparing data from year to year is useful and shows areas with potential problems.

Tree mortality in western Washington and northwestern Oregon has been, and probably will continue to be, relatively low with occasional local areas of high mortality from disturbances such as flooding, wind storms, fire, and insect outbreaks. The most significant mortality agent on the west side is root disease. Although not highly visible, root disease causes mortality on $10 \%$ of all lands in the Pacific Northwest and may kill more than 50\% of a stand over a period of years.

In eastern Oregon and Washington, forest inventories show mortality has been above 


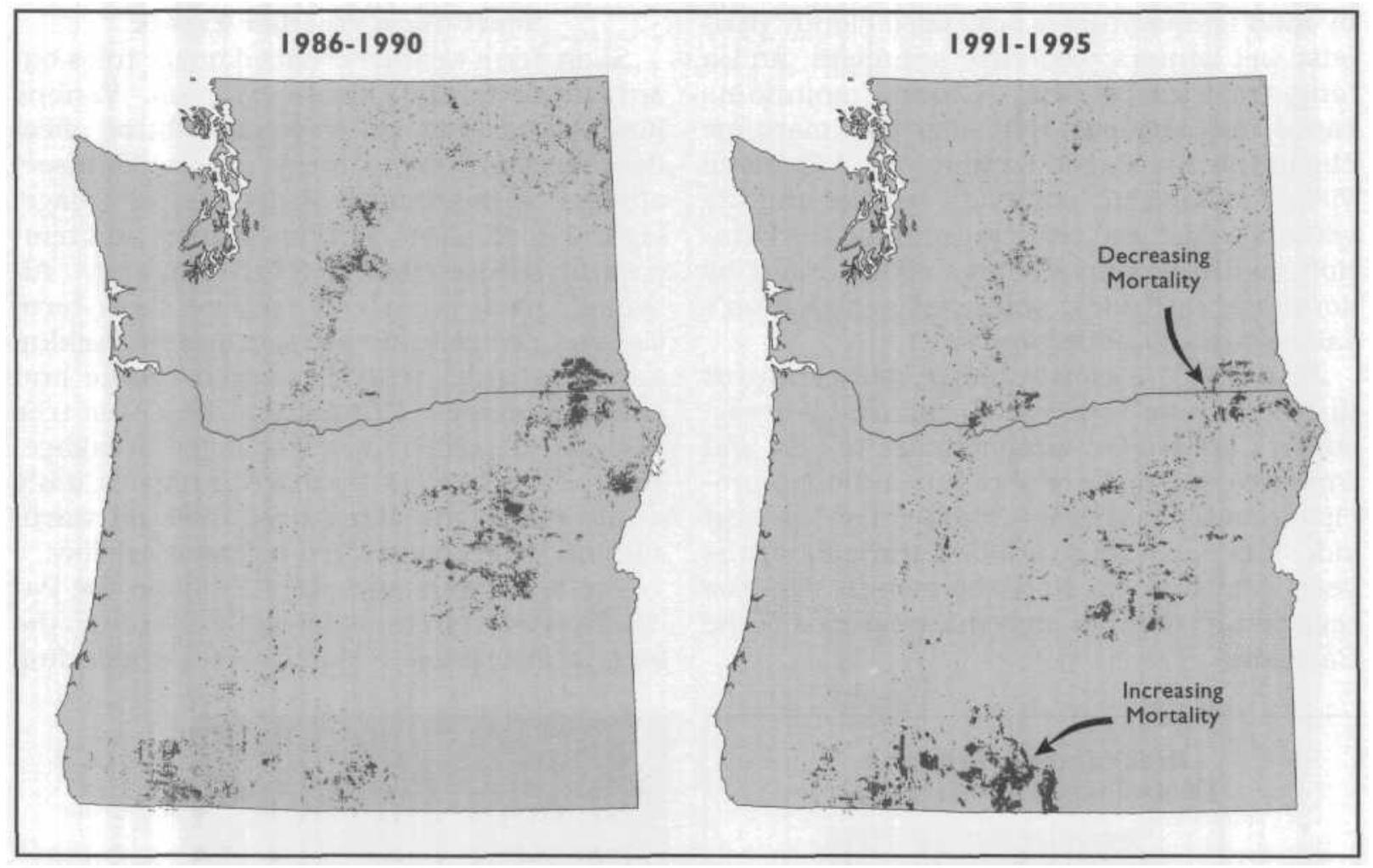

Mortality for five-year periods detected by annual aerial surveys. Trends can be seen, such as decreasing mortality in the Blue Mountains (northeastern Oregon) and increasing mortality in south-central Oregon.

Source: Cooperative Aerial Survey, Oregon Department ofForestry. Washington Department of Natural Resources and USDA Forest Service.

average over the past decade on both federal and nonfederal lands. Typical annual mortality in Oregon and Washington forests, based on 60 years of inventory data, is about $0.5 \%$ of the volume of wood present. The last inventories of eastern Oregon and Washington forests (excluding National Forests) show annual mortality at $0.84 \%$ for eastern Washington and $0.97 \%$ for eastern Oregon. National Forest inventory data show similar trends.

Annual aerial surveys for insect damage show that mortality visible from the air (mainly overstory trees; understory trees are difficult to see) has actually decreased in most of eastern Oregon and Washington over the past few years, after a period in the late 1980s when mortality from bark beetles was very high. Reduced mortality in the last few years may be due to increased summer rains which lessen tree stress and to the collapse of the current western spruce budworm outbreak.

\section{WEATHERAND ITS INFLUENCE ON FORESTS}

Weather influences forest health by directly damaging trees and by affecting the ability of trees to protect themselves against insects and diseases.

The climate of the Oregon and Washington is generally mild with dry summers. Great variation in local areas is due to the influence of elevation, proximity to the ocean, the northsouth mountain ranges, and prevailing storm paths. Differences in dominant vegetation reflect differences in climate across the region and the effects climate and weather have on plants.

The climate of western Oregon and Washington is strongly seasonal with less than $20 \%$ of the precipitation falling from May through July, the growing season for trees. The coastal areas have a maritime climate characterized 
by mild temperatures; prolonged cloudy periods; wet winters; cool, dry summers; and a long, frost-free season. Coastal mountains cause rain shadows that alter this maritime climate in the Puget Trough and Willamette Valley, making the summers warmer and the winters colder and reducing annual precipitation. With the rain shadows compounded by southerly latitudes, southwestern Oregon's valleys are still hotter and drier.

East of the Cascade Range, temperatures fluctuate more widely than in coastal areas, winters are colder, summers are hotter, and frost-free seasons are shorter. Although precipitation is considerably less than on the west side, it is much more uniform throughout the year. May and June are the months with the highest precipitation in some areas east of the Cascades.

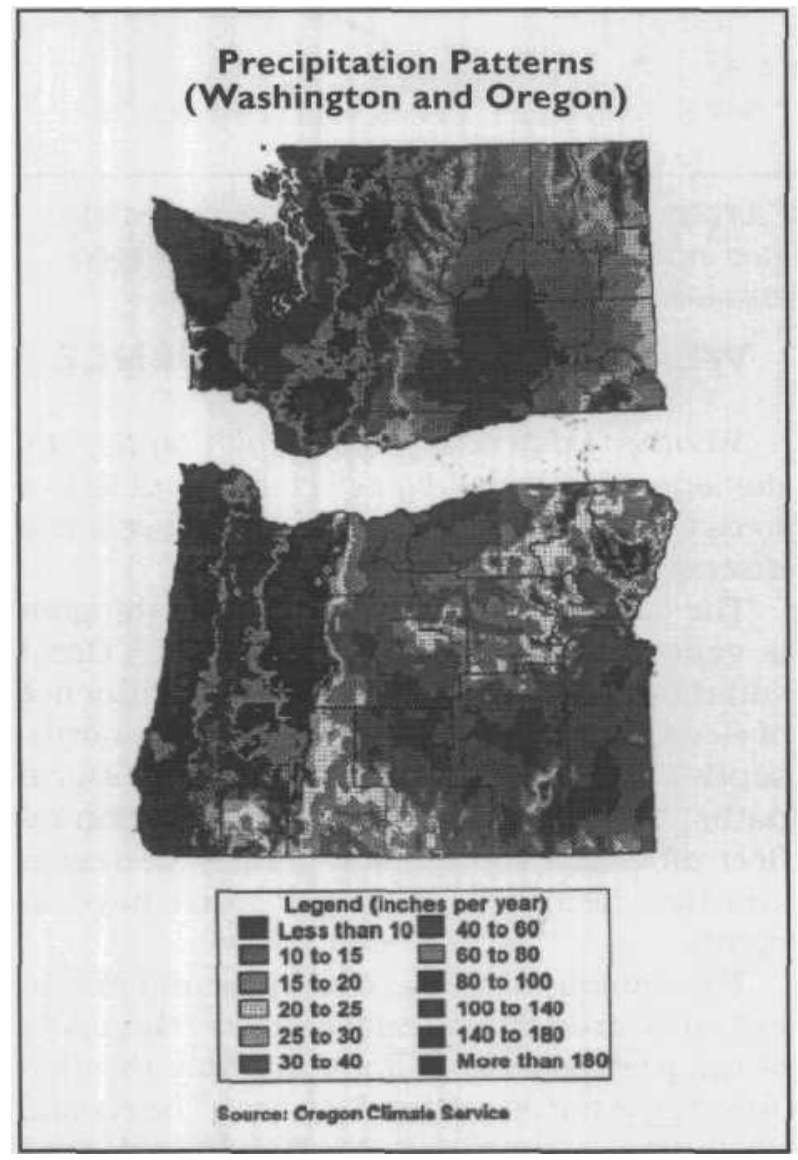

Precipitation patterns in Oregon and Washington

\section{Short-Term Weather Events}

Short-term weather events damage trees but are part of normal climate variation. Various kinds of weather kill trees outright or affect their susceptibility to injury, disease, or insect attack. Spring freezes shrivel tender foliage. Lightning damages portions of trees and temporarily reduces their defensive capacity. Although most trees can survive short-term flooding, complete submersion and silt buildup around trunks restrict oxygen intake and cause damage. Fungal spores enter tree wounds caused by wind or snow breakage. Many bark beetles take advantage of daily water stress, attacking host trees on warm summer afternoons when defenses are low.

The late 1980s and early 1990s in the Pacific Northwest were significantly drier than the long-term average. Many places-including

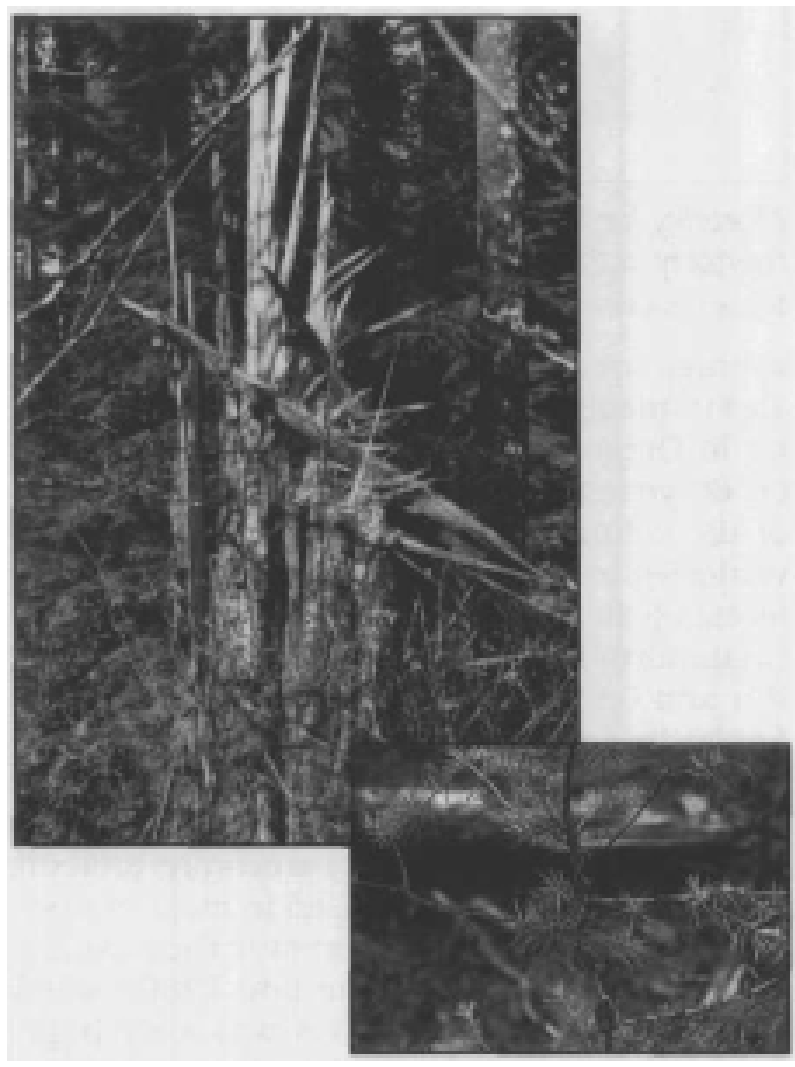

Extreme weather, such as wind storms (top), can kill trees outright. Some types of weather, such as hail (bottom), damage only parts of the tree but make it more susceptible to diseases and insects. 


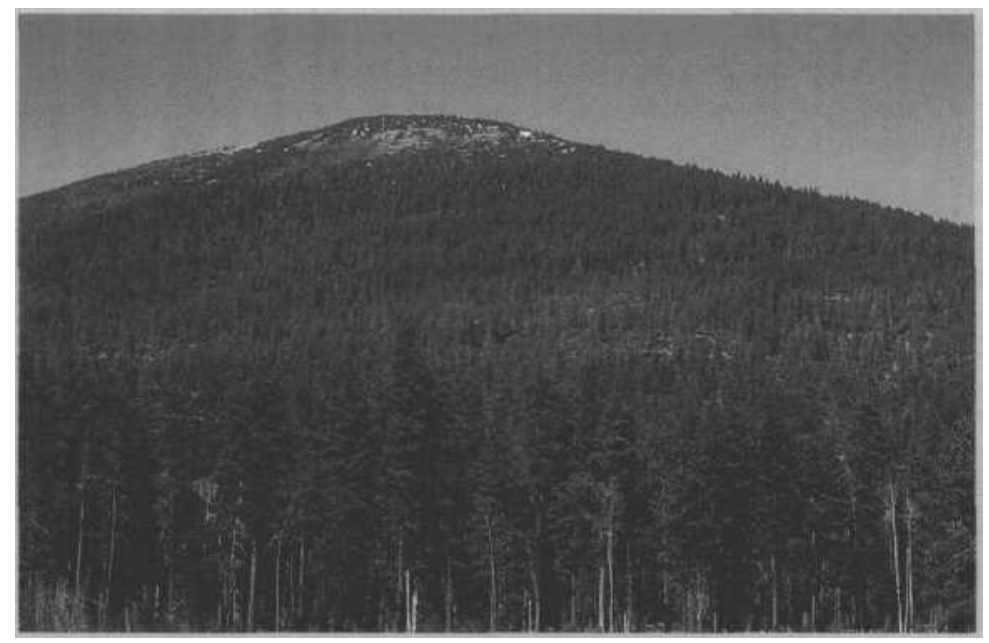

Conditions for winter wind damage often are restricted to a particular elevation, resulting in a band of damage called "red belt"

Winter Wind Injury: The process of transporting water from roots to foliage is passive. Evaporation from the foliage, called transpiration, creates a deficiency of water at the top of the tree. Additional water molecules are drawn up along the trees' conductive tissues to replace molecules that leave the foliage. The resulting water column is like a drinking straw. Additional liquid is drawn upward to replace any liquid removed from the top.

Injury can result to trees on warm, bright winter days. Pores on the foliage open to receive carbon dioxide from the air. Water begins to evaporate from the leaves and additional water is drawn into the roots to replace it. Water moves slowly through cold soils, however. The foliage loses water faster than roots can acquire it, causing the foliage and upper branches to desiccate and die.

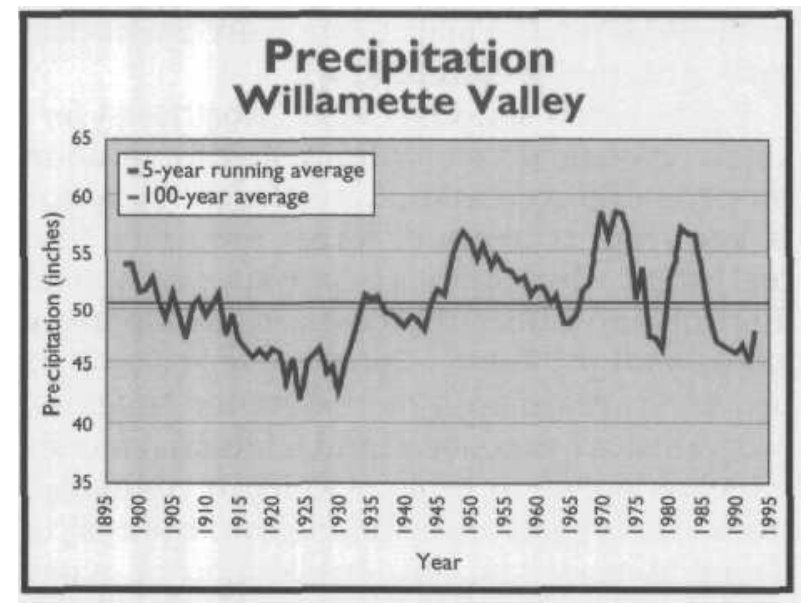

The precipitation record for the Willamette Valley illustrates the cyclic pattern of moist and dry periods in the Pacific Northwest source: Oregon Cmate Service, Oregon State University. southwest Oregon, the Blue Mountains, the Willamette Valley, and the Puget Sound areaexperienced this drought. Outbreaks of some insects, related to increased moisture stress on trees particularly in overstocked stands, often follow dry years. Over the last century in the Pacific Northwest, the most recent drought appears to be part of a cycle of wet and dry periods each lasting 10 to 30 years. This climate pattern is within a currently accepted normal range of variability.

\section{Long-Term Weather Changes}

Long-term climate changes have and will continue to produce changes in forests in Oregon and Washington. The environmental variable that limits forests most and defines forest community gradients is available moisture during the dry summers. Long-term changes 
in weather will also create changes in the intensity and frequency of natural disturbances, such as wildfire and wind storms, which influence forest composition and structure.

If the climate becomes significantly warmer and drier, forest communities may shift up slopes to higher, cooler, moister elevations; move to more northern latitudes; or move from southern to northern aspects. Because each plant species responds individually to the unique interactions of temperature, moisture, and site characteristics, some of the new communities are likely to be completely different assemblages from any community dominant today. Insects and diseases are likely to expand or contract their ranges along with their hosts, but they may also change their behavior or habitat in unexpected ways.

Because tree species are long lived relative to people, some of the forest changes caused by climatic fluctuations might not be obvious for decades or even centuries. Changes would be greatest in places where many species are already at their physiological limits (southwest Oregon, for example). An increase in insect and disease activity on relict populations, stressed by harsh site conditions, would be expected.

\section{The Future}

A challenge facing climatologists, ecologists, and land managers is to improve understanding of how dominant weather patterns are likely to change-in both the short- and longterms - and how these changes will affect forests. Although the climate has shifted in the past, determining if current trends in climate indicate a true climate shift or just a change within the normal range of variation is difficult. If a climate change is predicted, forest managers will need answers to many questions. How large will the change be? How soon is it expected to affect vegetation? How will plants, insects, and diseases respond? How will the industries and services that depend on forest communities be affected? Can forests be made more resilient to such changes?

\section{EXOTIC PESTS}

Trees have coevolved with their native pests for thousands of years. Forest health can be greatly affected when exotic pests are introduced and upset the balance.

Exotic plants and animals-those introduced from places outside of their native range_can be harmful to native species. Many introduced organisms are beneficial, such as crop plants, ornamentals, game animals, and livestock; these organisms were deliberately introduced and are essential to United States commerce and society. In the Pacific Northwest, the exotics that cause the most damage to forest trees are accidentally introduced insects and fungi. Introduced weeds are also destructive, competing with native forest vegetation for space, nutrients, and water.

\section{Problems With Exotics}

Without natural checks, the population of an introduced pest can grow rapidly and wreak havoc on the host organism. After a fungus disease-white pine blister rust-was introduced 86 years ago, western white pine has been significantly reduced in many Oregon and Washington forests where it once was common. The balsam woolly adelgid, an insect that was introduced to the Pacific Northwest in the 1930s, has damaged grand fir at low elevations in the Willamette Valley to such an extent that most are unable to reproduce.

Exotic pests seriously affect Northwest forests. Damaged trees diminish the value of property and recreation experiences. Revenue is lost from recreation, forest products, and real estate. Quarantines to prevent pest spread disrupt and affect the costs of transporting local forest products. Control efforts (such as pesticide treatments or resistance breeding programs) are expensive, and additional money must be spent to replace killed or damaged trees. In Oregon and Washington, the cost of trapping, analysis, and eradication of gypsy moth from 1985 to 1995 exceeded $\$ 50$ million.

Most important, undesirable exotics change forest ecosystems. Potential effects range from slight decreases in native populations to per- 

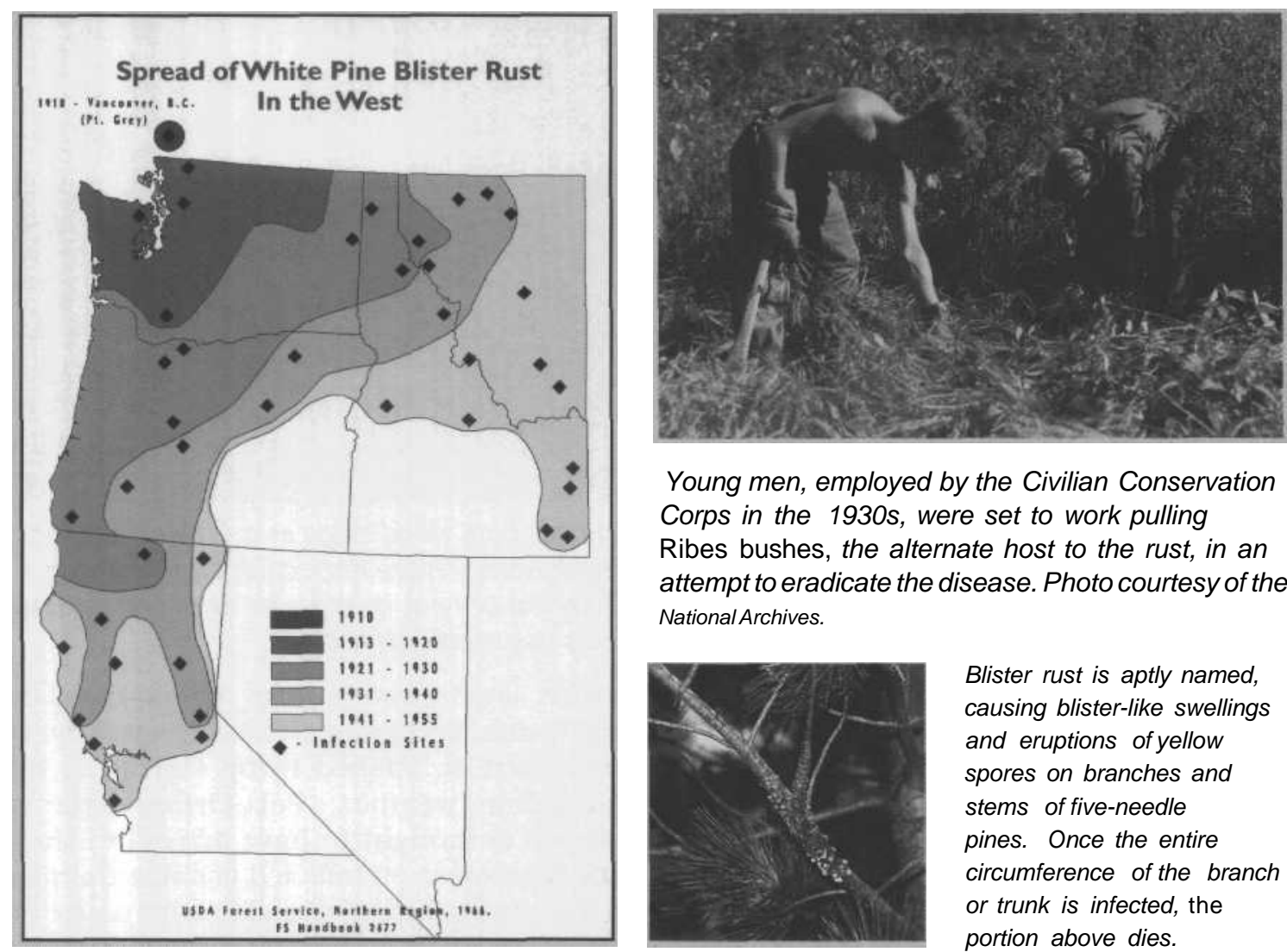

Young men, employed by the Civilian Conservation Corps in the 1930s, were set to work pulling Ribes bushes, the alternate host to the rust, in an attempt to eradicate the disease. Photo courtesy of the National Archives.

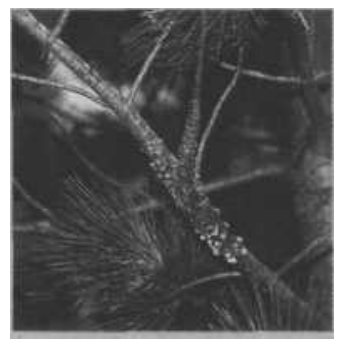

Blister rust is aptly named, causing blister-like swellings and eruptions of yellow spores on branches and stems of five-needle pines. Once the entire circumference of the branch or trunk is infected, the portion above dies.

White Pine Blister Rust: White pine blister rust was first found in the West in the summer of 1921. The disease was identified on eastern white pine seedlings, imported in 1910 from France and then planted at Point Grey near Vancouver, British Columbia. By 1922, rust infections had been discovered at many points along the Washington coast from the Columbia River north well into British Columbia. From that small beginning, this rust spread and infected all species of white pine found in the Pacific Northwest, including western white pine, sugar pine, and whitebark pine.

One early attempt at control was to eradicate the alternate host, currant or gooseberry plants /Ribes spp.). Many men were hired by the Civilian Conservation Corps (CCC) and Works Progress Administration (WPA) during the Great Depression years to pull and burn ribes bushes in Northwest forests. As recently as the early 1950s, many students worked their way through college pulling ribes. The cost of this program was almost $\$ 100$ million nationwide, with $\$ 62$ million spent in the West.

By 1956, the rust had spread to most of the white pine forests in the United States, and control efforts turned from ribes eradication and quarantine to managing the disease, recognizing that it had now become a permanent part of many western forests. Management concentrated on developing pines resistant to the disease and trying to return white and sugar pines to their previous roles in forested ecosystems. 


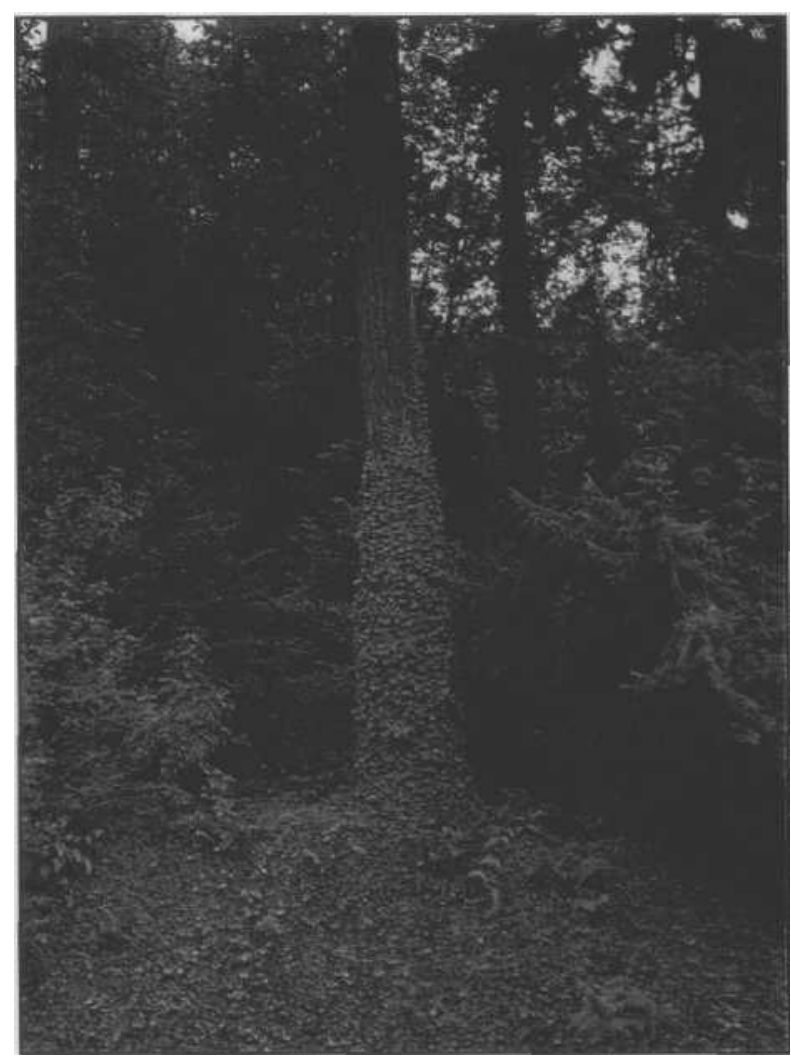

Introduced plants, such as the English ivy pictured here, can invade thousands of acres of forest before they are recognized as threats to native vegetation and wildlife.

manent alteration of biological communities. Although much attention is directed at introduced insects and diseases, the current and potential effect of introduced plant species on forests is huge. Not only do exotic plants compete with native vegetation but they can also change the physical and biological environment. Changes have been noted in moisture and nutrient status, microbial populations, and soil characteristics where exotic plants have become established. Organisms dependent on native plants and adapted to a particular environment are also affected.

\section{Introduction of Exotic Pests}

Exotic pests usually travel to new areas as hitchhikers. Weed seeds, fungus spores, insect eggs, cocoons, or larvae arrive on plants, fur-

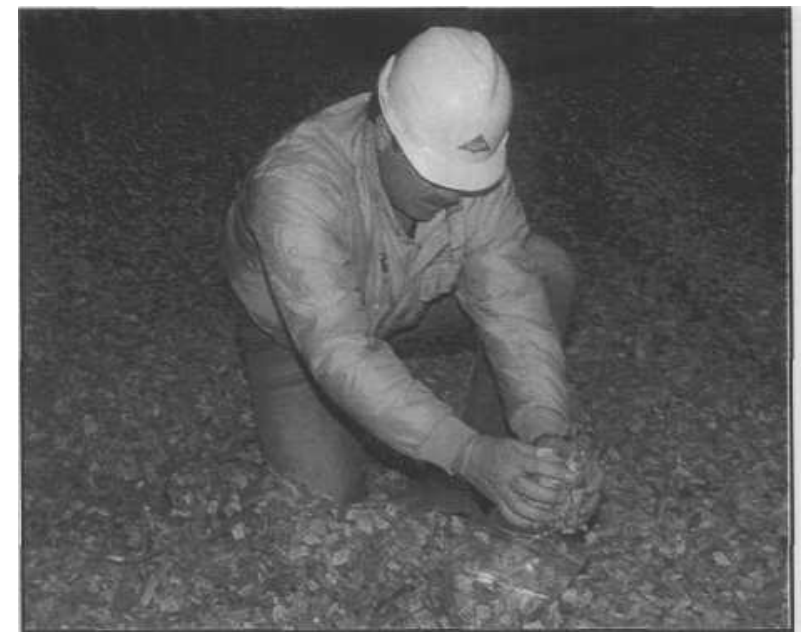

Radiata pine wood chips in a Chilean ship hold. Regulations require inspection and sampling. Chemical or heat treatments are used to destroy pests associated with chips.

niture, lawn mowers, logs, ships, cars, trailers, trains, and planes. Less frequently, they are blown or washed in by storms or other anomalous weather. Port-Orford-cedar root disease is thought to have arrived in the $\mathrm{Pa}$ cific Northwest on infected ornamental plants in the 1920s; it then spread to both native PortOrford-cedar in southwest Oregon and ornamental Port-Orford-cedar throughout western Washington and Oregon.

Increased travel, population expansion, and new trade with South America, Japan, China, and the former Soviet Union will contribute to increased introductions of plants and animals and increased chances that they will become established once they arrive. The benefits of economic growth for states such as Oregon and Washington resulting from trade with other countries has to be weighed against the risk of introducing new pests and the potential damage to forests. New regulations for imports of logs and lumber (and other unmanufactured wood items) have recently been implemented by the states and the Animal and Plant Health Inspection Service (APHIS), a branch of the U.S. Department of Agriculture, to reduce the risk of introducing forest pests into the United States. 


\section{Reducing Introductions}

Experts have suggested the following measures to slow introductions and prevent establishment of exotic pests.

- Evaluate the potential for introducing harmful pests with imports.

- Increase inspection and quarantine efforts, especially as transporting and shipping technology changes.

- Beware of accidentally introducing new plant species into forest ecosystems.

- Maintain detection programs so populations can be eradicated while they are still small and localized.

- Promote self-sufficiency in wood products so raw or unprocessed products do not need to be imported.

\section{Control and Eradication}

A pest becomes established once it is able to reproduce and maintain a population that survives from year to year. For exotic pests already established in Pacific Northwest forests, management strategies already in place are minimizing their effects: natural enemies such as predators and parasites are being released to control populations of some exotic pests; resistance breeding programs are in place for white pine blister rust and PortOrford-cedar root disease; and appropriate silviculture and pest management practices are applied in many areas to minimize exposure and spread. Unlike white pine blister rust or Port-Orford-cedar root disease, the European and Asian gypsy moths are not yet "established" in the Pacific Northwest. The moth populations are still too low to breed effectively and establish permanent populations. Eradication efforts, such as pesticide treatments, are the most practical and effective at this preestablishment stage. In 1996, ten urban areas in the Northwest were treated for gypsy moth to prevent their establishment.

\section{EFFECTS OF AIR QUALITY}

Air pollution alters the chemical environment in which plants grow and affects the health of the forest

The population in Oregon and Washington is projected to increase into the future, and with more people come more cars and other services that cause air pollution. Washington Environment 2010, a recent study by the State of Washington and the Environmental Protection Agency, projects that over the next 15 years, concentrations of the pollutants of greatest concern to natural resource managerssulfur compounds, nitrogen compounds, and ozone-will not improve. In fact, ozone is expected to increase by $30 \%$ in the Puget Sound area unless additional actions are taken.

Air-quality work in Oregon and Washington forests has focused on the effects of ozone on vegetation, using lichens as air-quality bioindicators, evaluating the sensitivity of alpine lakes to acid deposition, and determining the acidity of cloud water.

\section{Ozone}

Ozone is formed on warm sunny days from hydrocarbons and nitrogen dioxide emitted by cars and trucks. Unlike stratospheric ozone, 


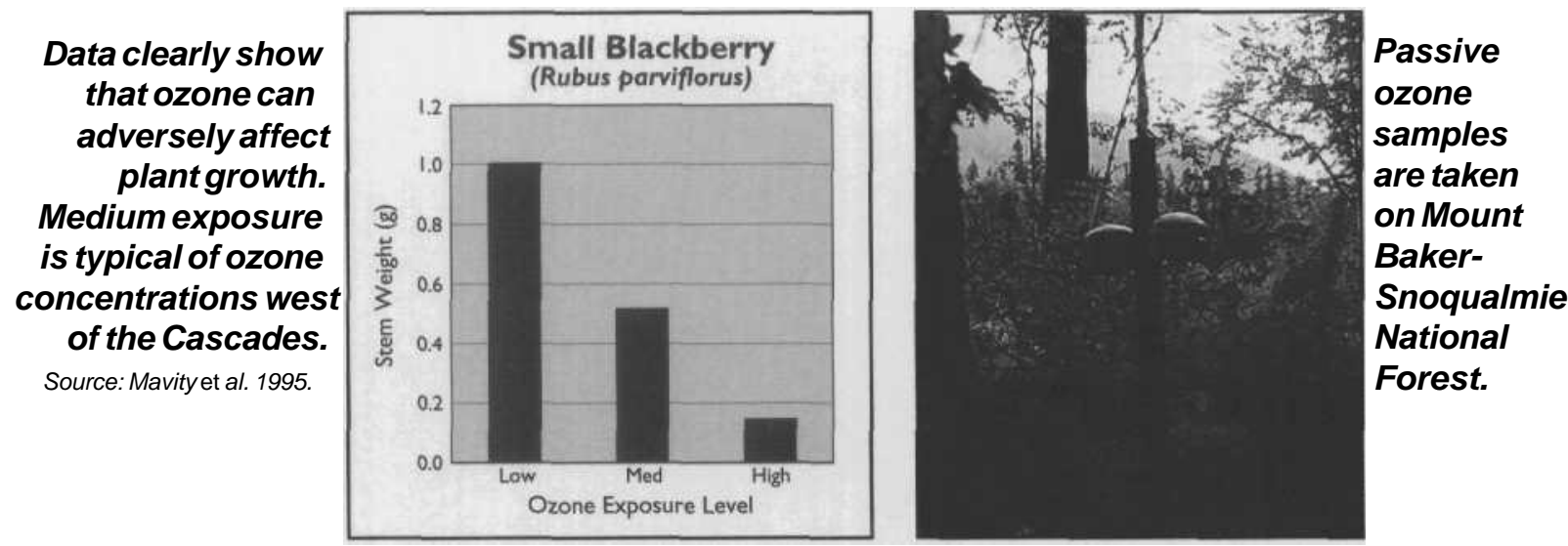

which protects life on Earth from the Sun's ultraviolet rays, ozone in the troposphere-created from nitrogen oxides and volatile organic compounds by sunlight - is known to be unhealthy for people as well as plant life.

Ozone is generally a problem to forest vegetation only in the summer when plumes of pollutants flow downwind from major urban centers. Possible effects to vegetation include visible leaf injury, reduced photosynthetic capacity, increased respiration, premature leaf death, reduced growth, and mortality.

Ozone damages the most sensitive plants at concentrations lower than those that are harmful to people. The federal human-health standard is 120 parts per billion (ppb). Lichens, a group of ozone-sensitive organisms, can be adversely affected at concentrations between 15 and $70 \mathrm{ppb}$. Effects on lichens are subtle but can ultimately be fatal. Entire lichen species can disappear from the landscape before anyone notices. Recent studies of native herbaceous seedlings and ozone profiles commonly found in the Pacific Northwest showed that typical ozone concentrations could cause damage and increase mortality of certain common species.

The Forest Service air program in Oregon and Washington and the Washington Department of Ecology currently measure ozone electronically at Darrington, for the Glacier Peak Wilderness; Packwood Lake, for the Goat Rocks Wilderness; and Wishram in the Columbia River Gorge. Ozone is also being measured in wilderness areas by passive sampling, which uses inexpensive coated filters that chemically react at a known rate when exposed to different ozone concentrations. The next step is to establish plots of ozone-sensitive species in the highest ozone-exposure areas downwind of the Puget Sound and Portland urban areas as another monitoring method.

Table I-I-Effects of declining air quality on lichen communities in the Pacific Northwest

\begin{tabular}{ll}
\hline Air quality & Effect on lichens \\
\hline $\begin{array}{l}\text { Good } \\
\text { Decline beginning }\end{array}$ & The most sensitive lichens are present and healthy. Diversity and biomass of lichens is high. \\
Decline clearly visible & The most sensitive lichens are overgrown by other lichens or algae. Young individuals are absent. \\
The most sensitive lichens are missing on conifers; other lichens are still abundant. The remaining \\
lichens show high diversity and biomass. \\
The most sensitive lichens are missing on hardwoods and conifers. Some of the remaining lichens \\
show pollution effects. Diversity and biomass are intermediate to high. \\
Very poor \\
$\begin{array}{l}\text { The most sensitive lichens are missing. All of the remaining lichens show pollution effects; } \\
\text { diversity and biomass are intermediate. }\end{array}$ \\
All lichens show strong pollution effects (high frequency of dwarfed, shrubby, compact growth \\
forms; discoloration; fungal parasitism; and overproduction of dispersal propagules). Diversity \\
and biomass are low to nonexistent.
\end{tabular}




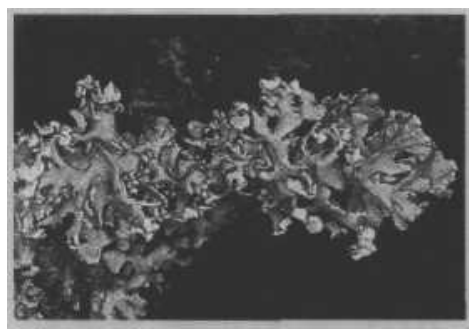

Lichens and mosses are "poikilohydric" organisms, meaning they cannot maintain constant internal moisture the way most plants do. Daily drying and wetting cycles concentrate pollutants dissolved in rain, fog, or dust in tissues, independent of their sensitivity to air pollution. Lichens are thus excellent accumulators of sulfur, nitrogen, and metals, as well as more elusive but long-lived pollutants such as radioactivity and pesticides. Deposition

Lichens are indicators of patterns and "hot spots" of specific air pollutants can be ozone and other pollutants. mapped by analyzing their concentrations in samples of Lichen species disappear as lichens and mosses. pollution increases.

\section{Lichens As Bioindicators}

Lichens (plants made up of a symbiotic association of alga and fungus) are sensitive to common pollutants in the Pacific Northwest: sulfur dioxide; oxidants such as ozone, acid rain, and fluorine; and some metals. Lichen species vary in their sensitivity to different pollutants. The presence or absence of different lichen species and the symptoms of pollution injury can help locate places with relatively high amounts of air pollution.

Lichens are being inventoried and monitored extensively west of the Cascades. Initial analysis of monitoring results showed a curious absence of leafy, nitrogen-fixing (air-pollution sensitive) lichens and an unexpected abundance of nitrogen-loving (pollution tolerant) lichens in the Willamette Valley and the Columbia River gorge.

\section{Acidity of Cloud Water}

Water in clouds and fog can become acidic through interaction with atmospheric pollutants. Plants can absorb this acidic moisture through aboveground parts or through their roots after the moisture condenses and drips to the ground. Acidic cloud water can inhibit growth of sensitive species. Cloud water was monitored during the summer of 1991 at Stampede Pass and Granite Peak in the Alpine Lakes Wilderness, and during the summer of 1994 at Green Mountain in the Glacier Peak Wilderness. The minimum acidity of cloud water $(\mathrm{pH}$ 3.6) collected in 1991 for both sites was far more acidic than is necessary to inhibit growth of some species. Unfortunately, the only information currently available about effects on local species is for conifer seedlings exposed to acidic fog under controlled conditions. More information is needed about the effects of acidic cloud water, as well as injury thresholds to local species, before cause for concern is verified.

\section{MONITORING METHODS}

Changes in forest health can be detected by monitoring the condition of the forest.

Several monitoring tools and methods are available for measuring the forest. Some have been used for years; others are new and have had only limited use. Many forest monitoring programs, such as forest inventories, focus primarily on vegetation condition and change. Other parts of the environment - like weather, air quality, riparian habitat, fisheries, and wildlife - are measured in separate surveys or, more recently, in multiresource surveys.

\section{Aerial Survey}

The Forest Service and the States of Oregon and Washington began a cooperative aerial survey for insect damage in 1947; only National Forests and some state lands were surveyed. From the 1960s and continuing to the present, all forested lands in the two states, regardless of ownership, are surveyed by air. The states also fly special aerial surveys to track specific 


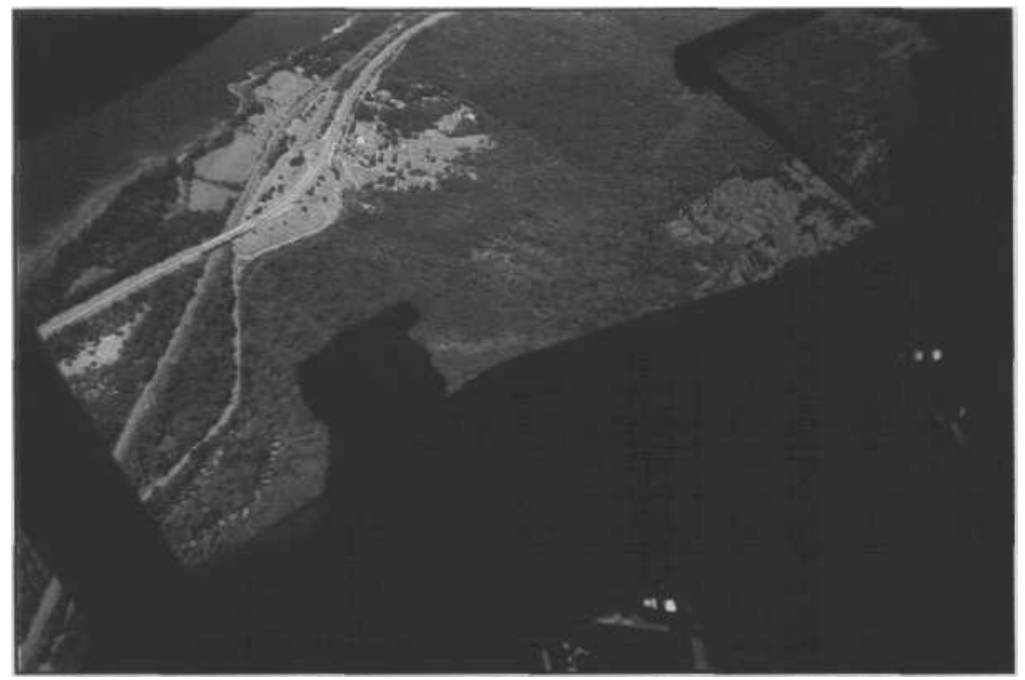

The aerial survey maps areas of mortality and defoliation in Oregon and Washington forests each summer. It is a cooperative effort by the Forest Service and the two state Forestry Departments.

problems, such as bear damage in coastal Oregon forests.

Survey results are used by Forest Service and state resource managers to track the approximate location and acreage of dying or damaged trees, to follow cycles of insect outbreaks, and to predict future damage. Land owners and managers use survey results to locate areas of insect or disease damage on their lands and to aid them in management decisions.

\section{Forest Inventory}

The Forest Service began to inventory the timber resource on federal, state, and private lands in the 1930s. In 1993, the $\mathrm{Na}-$ tional Forest inventory in Oregon and Washington was changed to a multiresource survey, in which understory vegetation, forest floor woody material, wildlife habitat, and damage agents are also recorded.

Forest inventories are groundbased (rather than aerial); they now consist of a series of systematically located plots that are remeasured periodically, at 8- to 10 -year intervals. Data from the plots are pooled to provide an estimate of forest condition across any grouping, geographic or biological.

\section{Forest Heath Monitoring Plot Network}

A network of forest health monitoring plots has been established on forested land of all ownerships across the United States. It consists of a series of ground plots on which variables, selected because scientists thought they would be good indicators of forest health, are measured. Although some variables are the same as inventory measurements, others are quite different, such as tallying the number and diversity of lichens as indicators of air quality.

Forest Health Monitoring is a national program, a partnership between several federal and state agencies. The program was started in the Northeast in response to concerns about acid rain and

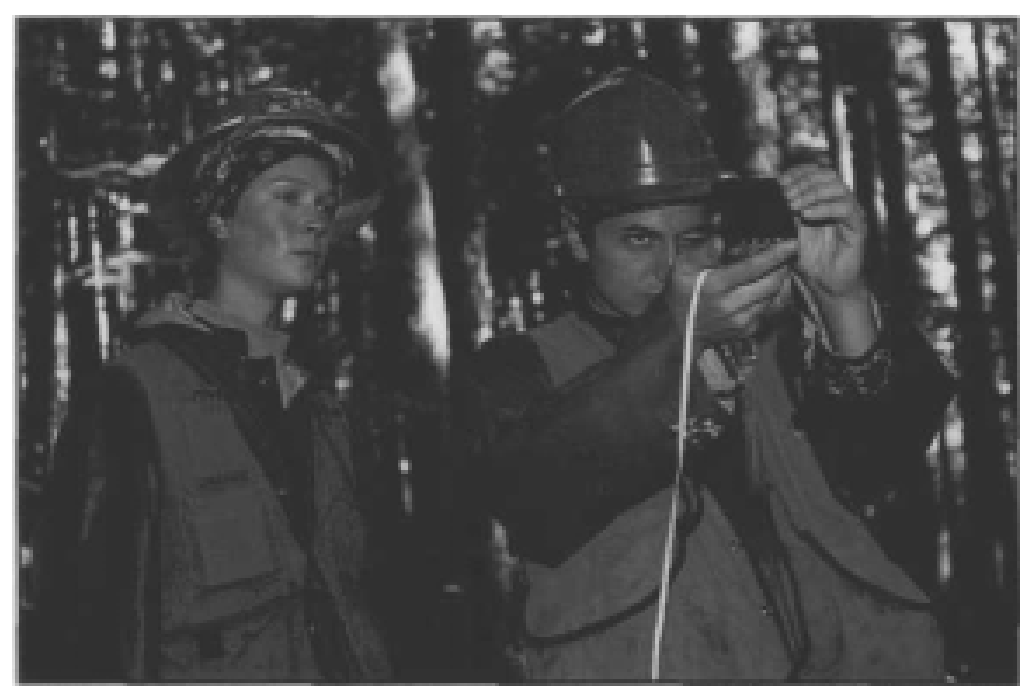

Inventory crews visit permanent plots periodically to measure and record a variety of attributes such as tree size, understory vegetation, woody material, and damage. 
now includes 19 states. Oregon and Washington established and measured 25 plots in 1994 as a pilot project (see chapter 5 for results of the pilot project). The two states are scheduled to fully implement the program in 1997. The purpose of the Forest Health Monitoring program is to determine the condition of forests over large areas, such as the West or the entire United States, and to detect changes in forest health at a broad scale.

\section{New Monitoring Technology}

The launching of satellites and the explosive growth in computer technology have created many possible applications of new technologies to forest monitoring. Commercially available satellite imagery of forested land can be sorted and classified to identify species composition, tree size, and canopy density for any given area of forest. Changes in vegetation can be detected by periodic comparisons of satellite images. In Oregon and Washington, satellite imagery of the National Forests is being purchased, classified, and used by the Forests.

Geographic information systems (GIS) are used extensively to store and retrieve aerial survey and other monitoring data. These systems geographically reference each piece of information and allow maps to be made that include many layers of data. Another new technology is the global positioning system (GPS). Using signals from several satellites, a portable GPS unit can calculate the precise location of a field plot. Currently, GPS units are taken to each forest inventory plot to record plot location. The location can then be entered on a GIS, and the inventory data for that plot can be related to other data for that particular location.

\section{Risk Rating}

Monitoring susceptibility, or risk to disturbance agents, is another way of monitoring forest health. Using stand examination data from site visits, inventory data, aerial photography, and knowledge of forest conditions conducive to insects, disease, and fire, forested areas can be assigned a rating of current risk to a particular disturbance agent. Over time, risk can change through "natural" maturing of the forest, removal of some trees by a disturbance, or management activities such as thinning, prescribed fire, or harvest. Subsequent risk ratings using updated information can show these changes in risk. Several computer programs for risk rating stands and watersheds are being used by National Forests to assist them in watershed analysis. 


\section{995 FOREST DISTURBANCE IN OREGON}

Root diseases \& dwarf mistletoes continue to cause subtle but significant mortality and growth losses. Swiss needle

cast on the coast is a concern.
Fire suppression contributes to overstocking, species changes, and increased risk of disturbance (fire, insects, diseases). Overstocked stands experiencing bark beetle outbreaks.
Western spruce budworm and tussock moth outbreaks collapse throughout state.

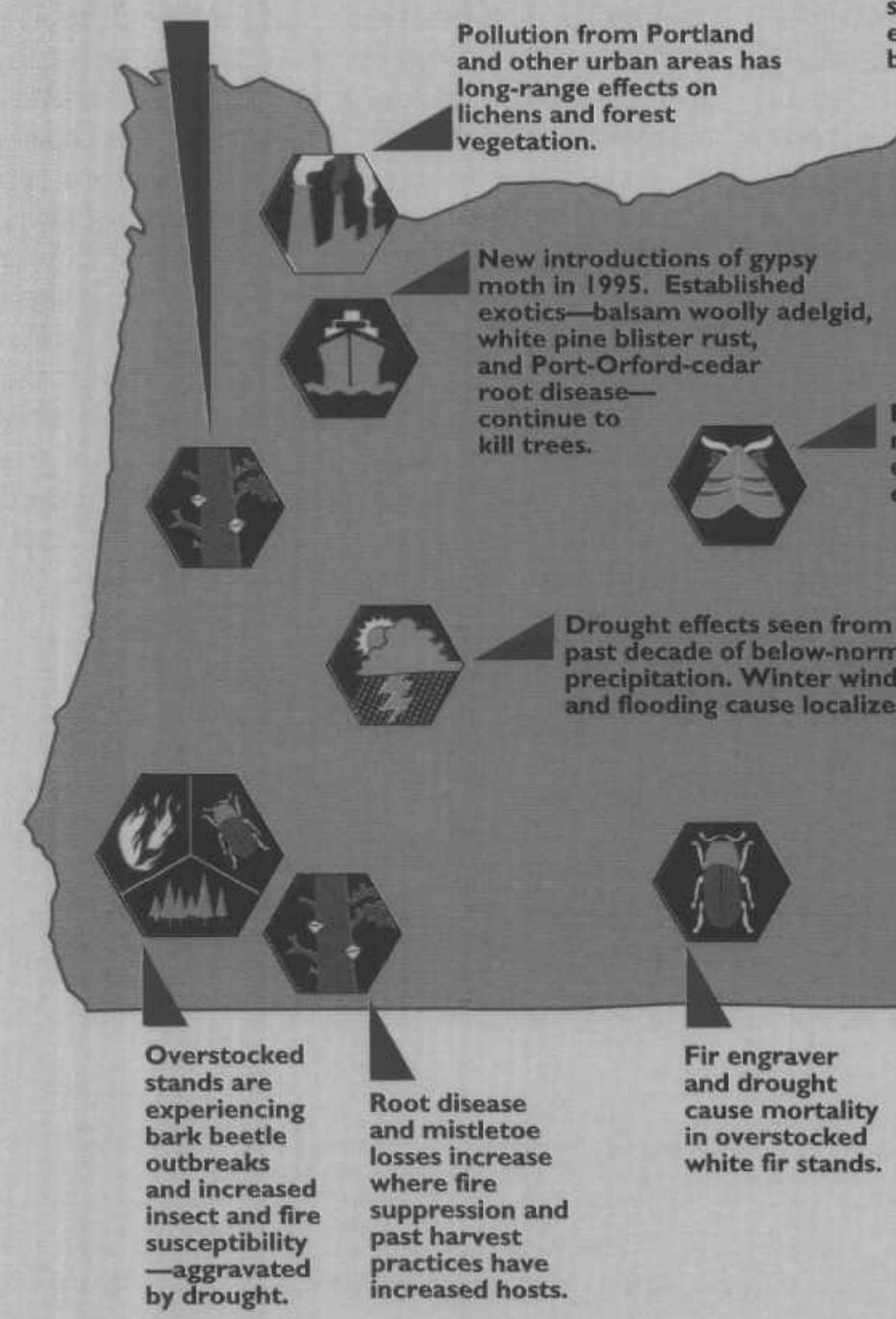

Oregon-24 


\section{CHAPTER 2. DISTURBANCE AND FOREST HEALTH IN OREGON}

\section{OREGON COAST RANGE (M242A) AND WESTERN CASCADES (M242B)}

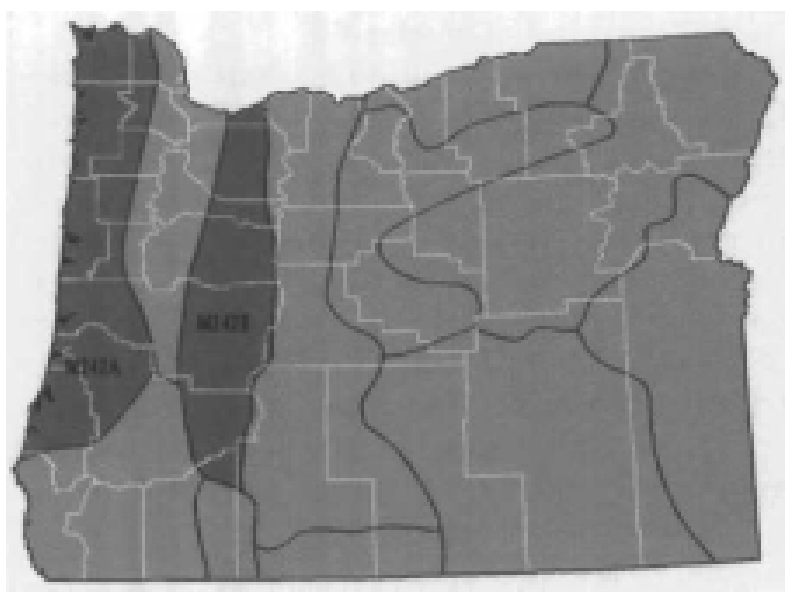

Ecology

Steep, highly dissected mountain slopes dominate the topography of the Oregon Coast and western Cascade Ranges. Because of the marine influence, the coastal region has the warmest winters, coolest summers, and greatest rainfall in Oregon. More than 100 inches of rain fall on the western slopes of these ranges; the drier eastern slopes of the Coast Range average only 30 inches per year. Although July through September is very dry, fog contributes significant moisture along the coast and lower western slopes.

Douglas-fir dominates forests of the Coast Range, extending from near sea level to about 4,000 feet. A pioneer species that reproduces after fire or other disturbances, its long life span allows it to persist during extended stable periods and reseed an area after a disturbance. Forests of the lower mountain slopes and the coastal fog belt are dominated by Sitka spruce, western hemlock, and western redcedar. Other conifers in the Coast Range include grand fir, noble fir, Pacific yew, and lodgepole pine. Red alder is the most abundant and important deciduous species in coastal forests.

Low and mid elevations of the western Cascades are dominated by Douglas-fir and western hemlock, with western redcedar, bigleaf maple, and red alder common in drainage bottoms. As elevation increases, Pacific silver fir, noble fir, Subalpine fir, mountain hemlock, lodgepole pine, sugar pine, and Engelmann spruce increase in importance. Western white pine is a minor component, and whitebark pine is common along the crest.

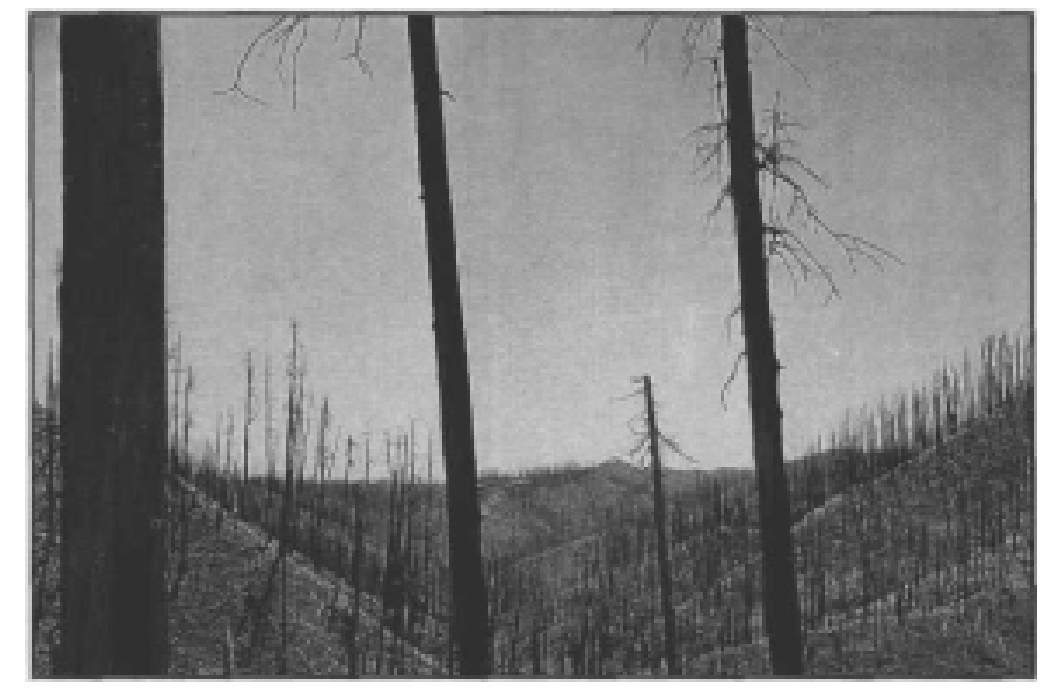

In the Oregon Coast Range, the most notable fire in recent history was theTillamook burn, which destroyed 255,000 acres of forest land in the I 930s. Photo courtesy of the Oregon Historical Society (neg. 55029). 
ing most trees, such as in the Tillamook burn in the 1930s. These large fires are usually associated with drought years and warm dry winds. Douglas-fir establishes well after intense fires, and many present-day Douglas-fir forests owe their beginnings to fire. The earliest Douglas-fir plantations were established after a fire in the Coast Range around 1915.

Wind and root disease cause windthrow-Periodic severe windstorms, typically between October and March, can cause extensive windthrow. Root disease and stem decay are the most common biological factors predisposing trees to windthrow. If blown down trees are Douglas-fir, the Douglas-fir beetle is likely to attack and kill standing trees for 2 years after a windstorm. During an outbreak, the beetle typically kills about one live tree for every three or four that were windthrown. Mortality can be prevented if windthrown trees are salvaged or beetle repellents used. This interaction of wind, root disease, and bark beetles creates canopy gaps, mixes soils during tree uprooting, and increases structural and biological diversity in stands.

The November 1995 windstorm in Oregon blew down trees on thousands of acres in the Coast and Cascade ranges. Mortality caused by Douglas-fir beetle is expected in areas where trees are not salvaged or protected.

\section{Douglas-Fir}

Douglas-fir is plagued by root diseasesLaminated root rot, a native disease that affects many conifer species, is the most widespread and destructive disease of Douglas-fir in the Coast Range and western Cascades. Various surveys estimate that, on average, patches of laminated root rot occupy 3 to $5 \%$ of the Douglas-fir forest, but the disease is distributed unevenly. Many stands in the northern Coast Range have more than $15 \%$ of their area occupied by root disease patches.

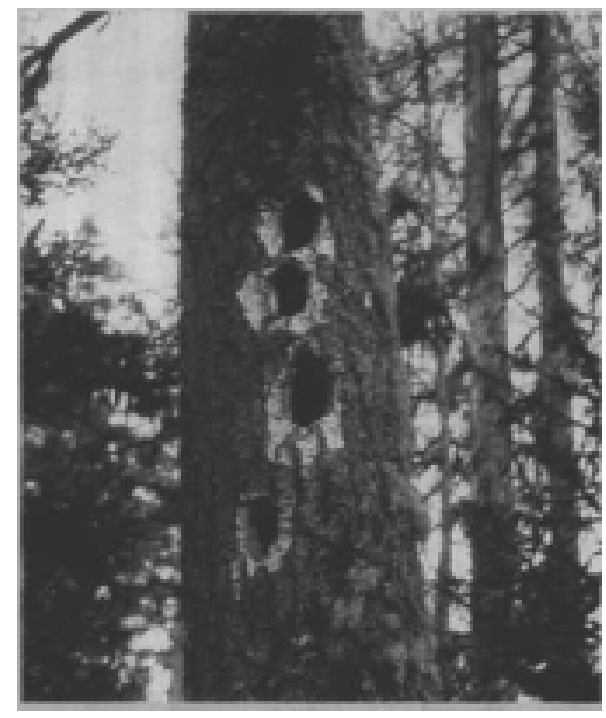

Decay provides habitat for wildlife.
Stem decay-too much or too little? As stands mature, decay organisms cause tree death or breakage, creating gaps in the canopy and providing rotten wood and hollow logs that are used by wildlife. Although there are benefits to wildlife, decay and stain can severely reduce timber value. In managed western Oregon stands, the harvest of old trees has decreased the average tree age and amount of decay, especially on private lands. A concern in areas with extensive young stands may now be the lack of decay and defect and its probable effect on wildlife and ecosystem processes.

The amount of decay in trees depends on tree species (some species are more susceptible than others), and generally increases with the frequency of wounding, and the size and age of the wound. The amount of decay in a stand can be reduced by keeping rotations short and avoiding tree injury during management activities such as thinning.

Decay can be increased by intentionally damaging trees, retaining defective trees, and inoculating trees with wood decay fungi. The tradeoff between wood production and rotten wood for wildlife needs must be balanced through thoughtful long-range planning. 


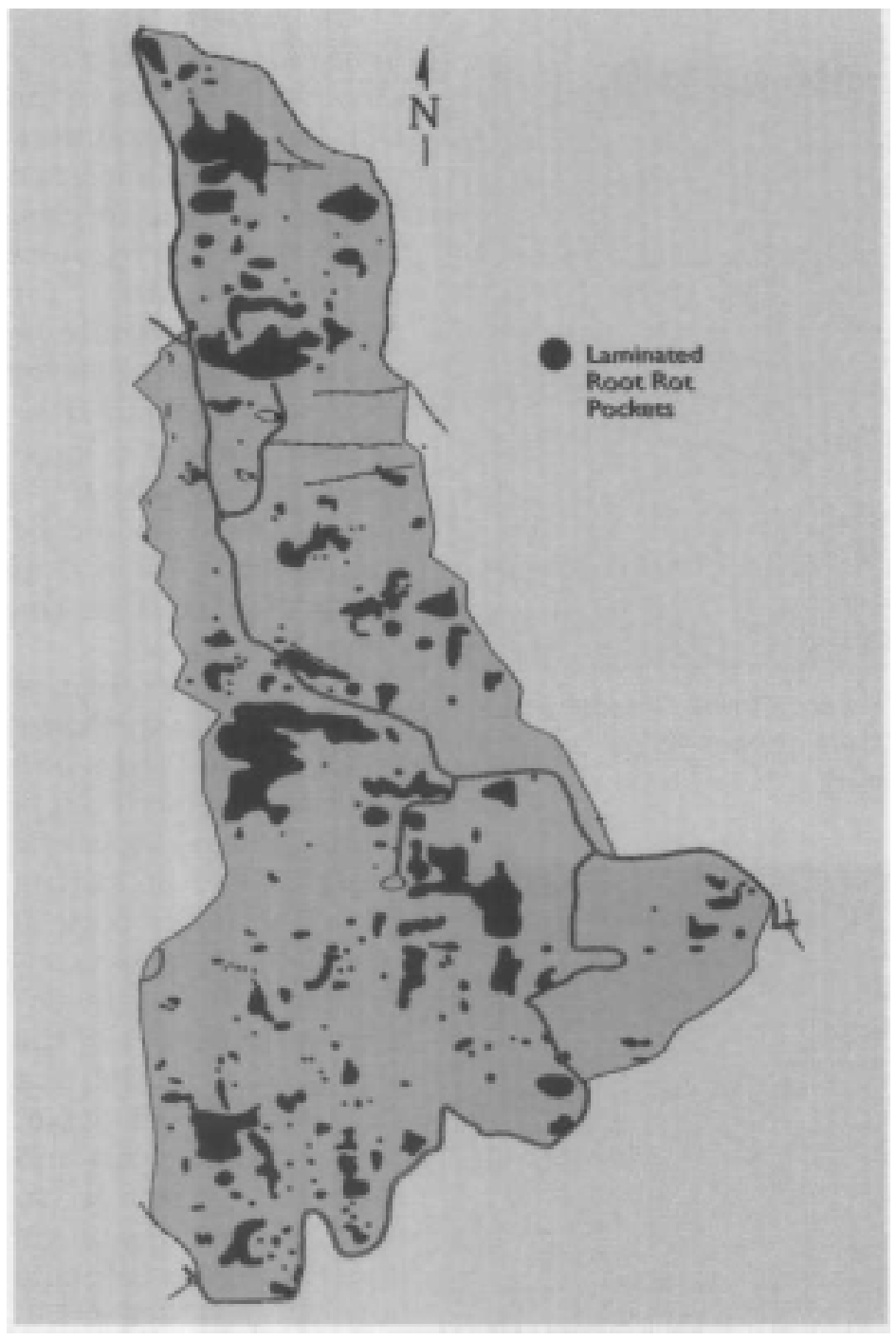

Laminated root rot creates different-sized openings, as shown in this map of a 50-year-old Douglas-fir stand in the Forest Grove District, Oregon Department of Forestry.

Source: Oregon Department of Forestry survey.

Laminated root rot causes tree mortality and growth loss; it also predisposes trees to windthrow. Because the disease spreads from root to root and affects groups of trees, it commonly creates canopy openings of various shapes and sizes. These openings allow light to penetrate to the understory, stimulating growth of herbs, shrubs, and tree species resistant to the disease. Trees killed by the dis- ease provide short-term snags and logs, which benefit many wildlife species. The increased diversity and benefits to wildlife partially offset the huge volumes of timber lost to this disease annually.

Laminated root rot intensifies on a site when Douglas-fir or another highly susceptible species are planted in an infested area and the fungus, which survives for decades in buried roots, grows from infected roots onto the roots of the newly established tree. Some of the most severe damage is in the Coast Range, where diseased stands were burned or clearcut and planted with Douglas-fir. Current management emphasizes planting or retaining resistant or immune species and carefully designing silvicultural systems to prevent blowdown after thinning.

Armillaria and black stain root diseases are far less abundant and damaging than laminated root rot but occasionally cause significant damage in young Douglas-fir plantations, particularly those stressed by poor planting or soil compaction. Both diseases are often found on the edges of laminated root rot patches.

Swiss needle cast damages coastal Douglas-fir-Swiss needle cast is a native foliage disease of Douglas-fir throughout the Coast Range and western Cascades. It impairs the tree's ability to regulate water loss and causes premature loss of needles. Severely damaged trees grow poorly and may die.

In most areas, the disease is of little consequence, causing premature shedding of 3- and 4-year-old needles. Since the early 1980s, however, thousands of acres of Douglas-fir plantations along the north coast have shown increasingly severe damage from this disease. In late winter and early spring, diseased plantations are noticeably yellow to brownish yel- 


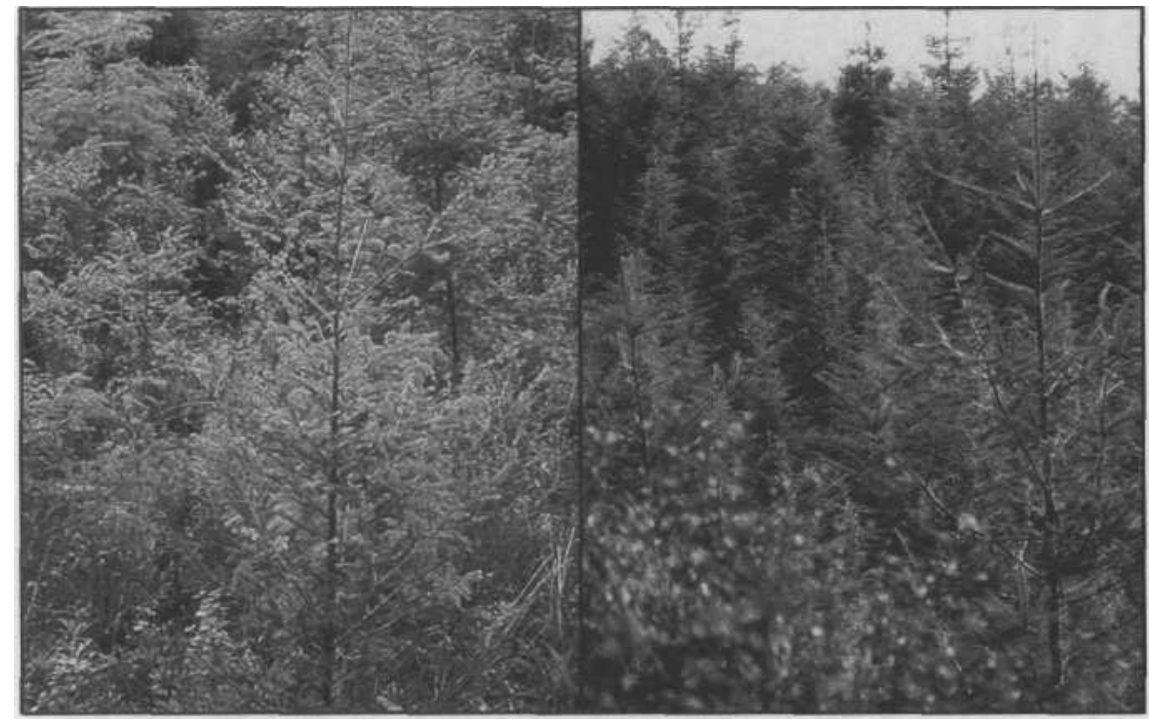

Swiss needle cast has become increasingly severe during the last decade along the north Oregon coast Diseased stands appear yellow and grow poorly (left) compared to healthy stands (right).
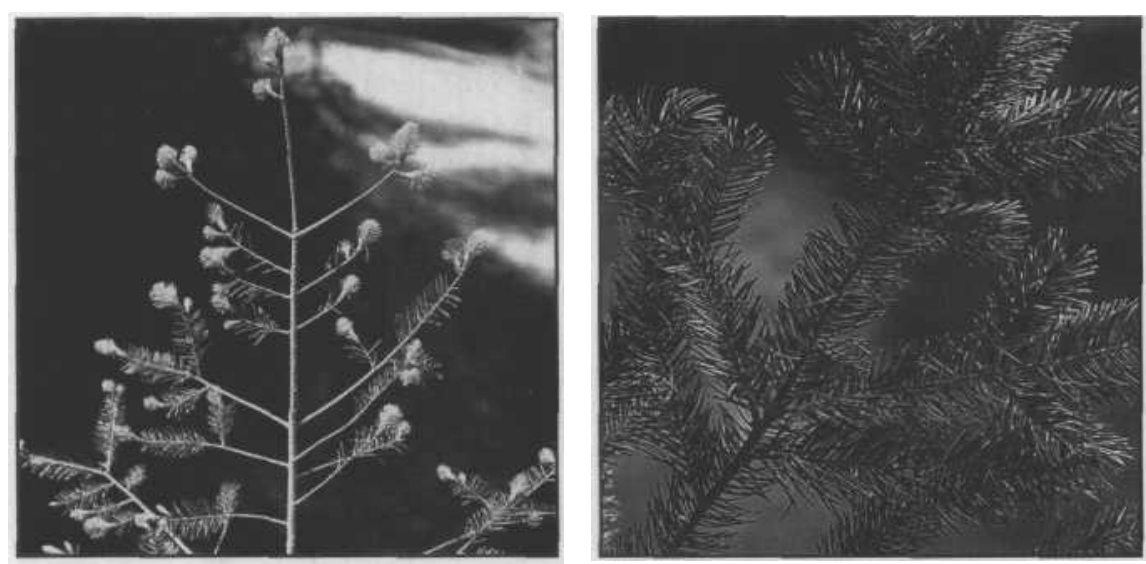

Trees with Swiss needle cast may lose all but the current year's needles (left), in contrast to healthy branch (right). With so little foliage remaining for photosynthesis, tree growth declines and some trees die.
The severity of symptoms differs considerably among individuals in the Douglas-fir population, indicating that tolerance exists within the species. The current management recommendation for areas with moderate or severe damage is to favor species other than Douglas-fir whenever possible. If Douglas-fir is planted, seed should be from parent trees that performed well in the coastal fog zone.

Black bears injure and kill young Douglas-Jir-Black bears peel and eat the inner bark of young conifers, especially Douglas-fir, in spring when the inner bark is succulent and sugar content high. When the entire circumference of the bole is peeled, the tree dies. Partial peeling can reduce tree growth and vigor, and provide an entry point for organisms that decay the valuable butt log. An Oregon Department of Forestry study of Coast Range bear damage found that for every tree with its entire circumference low, in contrast to adjacent natural stands that are green and vigorous. Most plantations with severe symptoms are 10 to 25 years old and within 15 miles of the coast in the fog zone. Much of this area was previously dominated by hemlock, spruce, or western redcedar. Why this native disease has become so severe in this area remains unclear. peeled, at least two other trees were partially peeled.

Bear damage is common in Douglas-fir stands in the 16- to 25-year age class, often soon after the stands have been thinned. In these stands, bears prefer the most vigorous and largest diameter trees. Although bears damage trees throughout the Coast Range and 


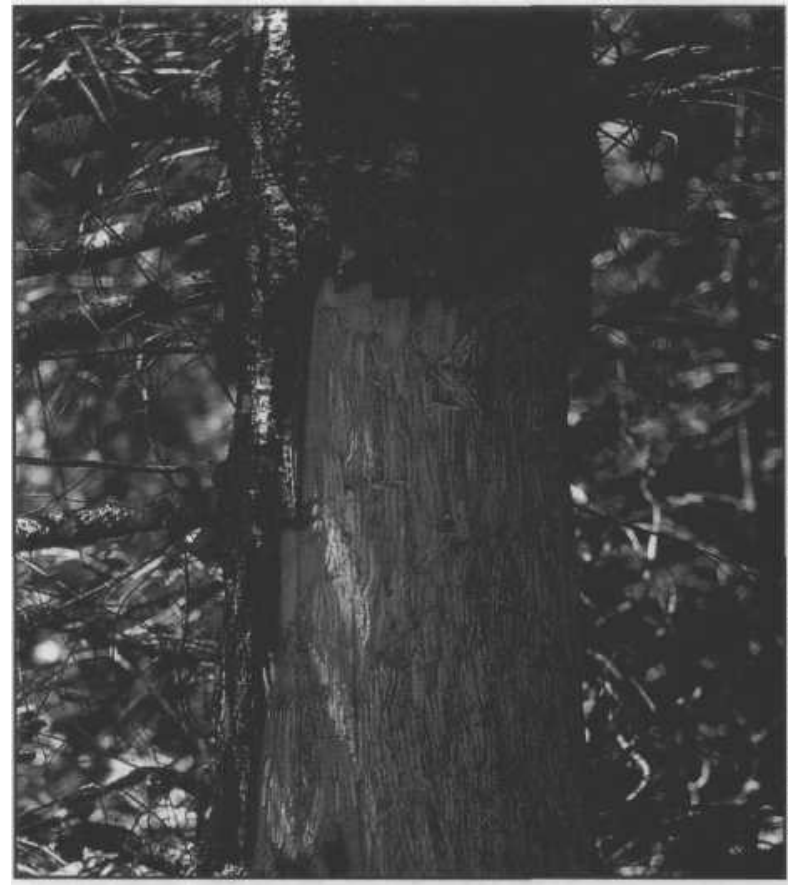

Black bears peel and eat the sweet, succulent inner bark of young Douglas-fir in the spring. Bear-killed trees occur on about 40,000 acres annually in western Oregon.

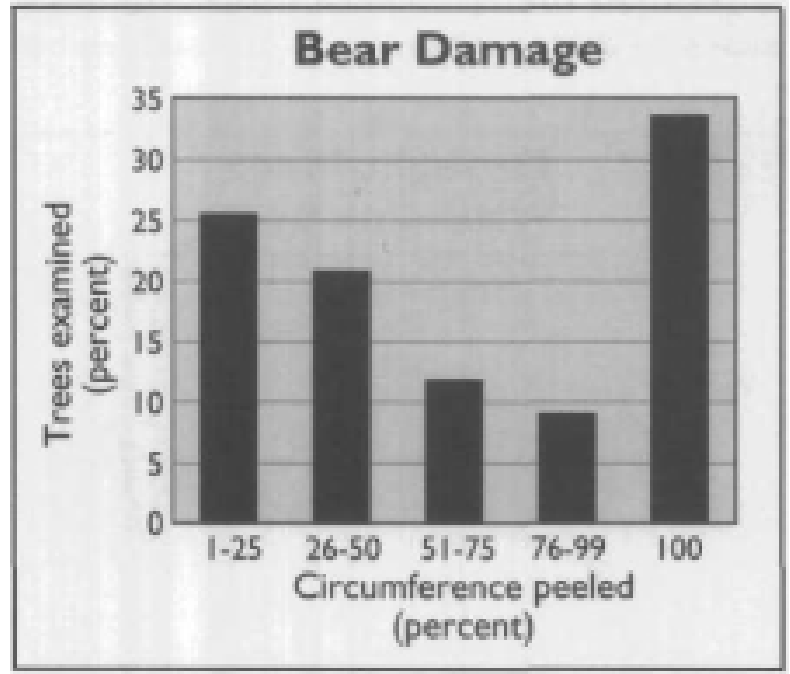

A survey of bear-damaged Douglas-fir in western Oregon found about one-third of the damaged trees were completely girdled and destined to die. Those girdled 76 to $99 \%$ are also likely to die.

Source: Oregon Department of Forestry survey. western Cascades, damage intensity differs considerably from one area to another. Surveys since 1988 do not show a clear trend of increasing or decreasing damage. Damage in some areas is severe enough to warrant bear management programs.

\section{Various Species}

Western hemlock, Sitka spruce, and western white pine are affected by several insects and diseases-In northwest Oregon, western hemlock is host to annosus root disease, hemlock dwarf mistletoe, and hemlock sawfly and looper. Sitka spruce weevil is an important pest of Sitka spruce regeneration in

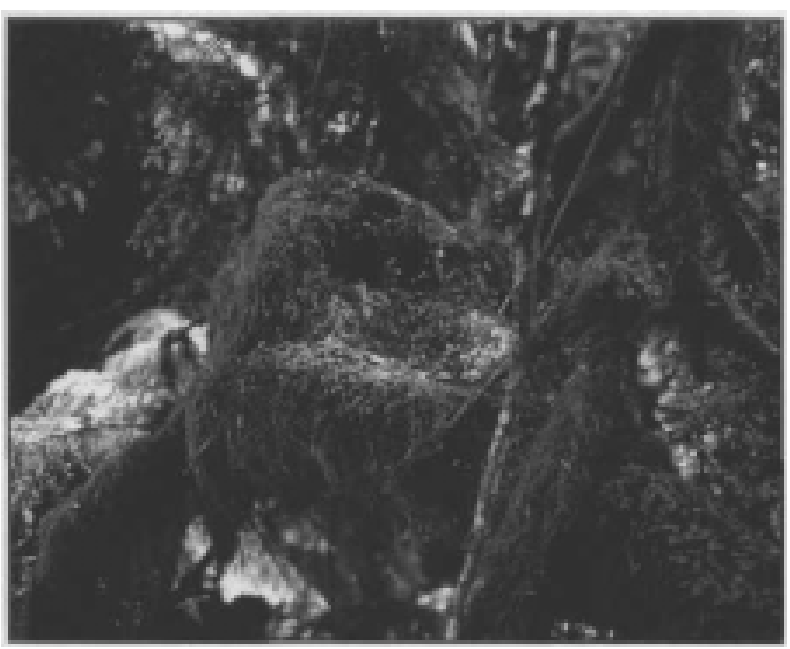

Hemlock dwarf mistletoe causes witches brooms, deforms branches, and decreases tree growth. Some wildlife species, such as the marbled murrelet, nest in branches deformed by dwarf mistletoe. Photo courtesy of Kim Nelson.

coastal Oregon and has deterred foresters from regenerating spruce over much of its natural range. The range and abundance of western white pine, found mostly in the western Cascades, has been reduced by the introduced disease white pine blister rust. But planting seedlings bred for resistance to the disease, pruning young trees, and rating sites for hazard is ensuring the continued presence of western white pine in Northwest forests. 


\section{WILLAMETTE VALLEY (242A)}

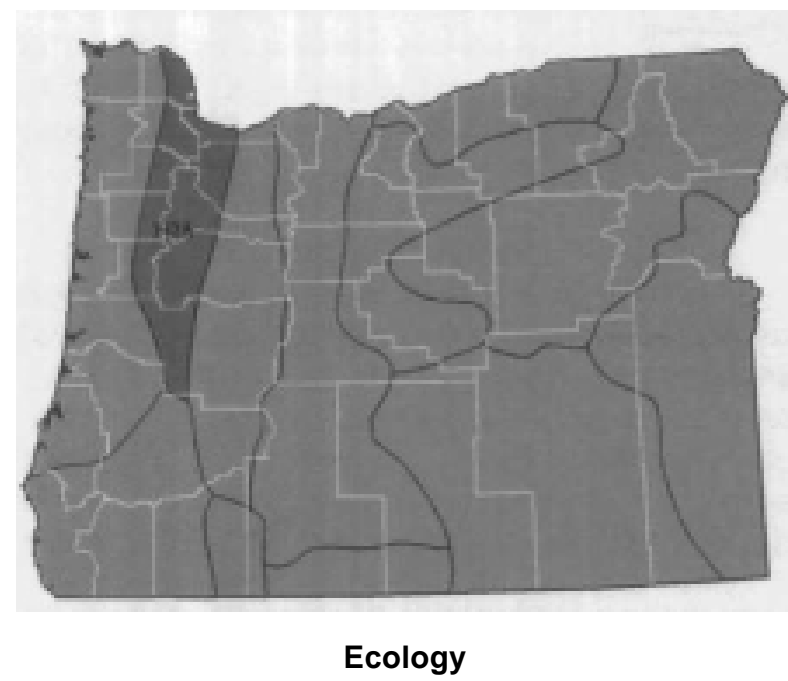

The forests of the Willamette Valley are stands, groves, or savannas of Douglas-fir and Oregon white oak, with scattered ponderosa pine. Western hemlock, grand fir, and western redcedar grow on the wetter sites, as do bigleaf maple, black cottonwood, red alder, and Oregon ash. Most of the land lies between 50 and 1,000 feet in elevation, with a few hilltops on the eastern edge reaching 1,500 feet. The summers are hot and dry; annual precipitation ranges from 25 to 60 inches, most of it between October and June.

Although the Willamette Valley is characterized by a summer drought, weather records show that the severity of drought fluctuates in 10 - to 20 -year cycles. The mid 1980 s to the early 1990s was generally drier than normal, and the next 10 to 20 years are predicted to be wetter than normal.

\section{All Species}

Lack of jire has caused species shifts in the Valley-Historically, fire was periodic in the Willamette Valley, either started naturally or set by people to maintain open areas. Frequent, light, ground fires maintained oak and pine stands because the large thick-barked trees tolerated fire better than did young oaks, grand fir, or Douglas-fir. In the last century, fire has been excluded, and many oak stands are now losing the competitive race with Douglas-fir and other species. Without the return of fire, and with increased urbanization and agriculture, oak and pine stands will likely diminish slowly in the Willamette Valley.

Air pollution increases with increasing people-The population of the Willamette Valley has greatly increased over the past few decades, mostly in the Portland area. Future projections are for continued growth. Population growth will be accompanied by increased pollution from automobiles and light and heavy industry. Air pollution not only affects visibility and human health, but also damages forests.

Ozone is a pollutant that affects forests. Monitoring of both vegetation and air has shown that ozone concentrations in some areas are high enough to cause plant damage. In the Willamette Valley, the number of lichen species, which are more sensitive to ozone than other plants, has decreased in some areas. The number and diversity of lichens, as well as the concentration of pollutants in lichen tissue, are being monitored to identify forested areas with ozone damage.

Drought interacts with insects and diseases to damage conifers-The sudden ap-

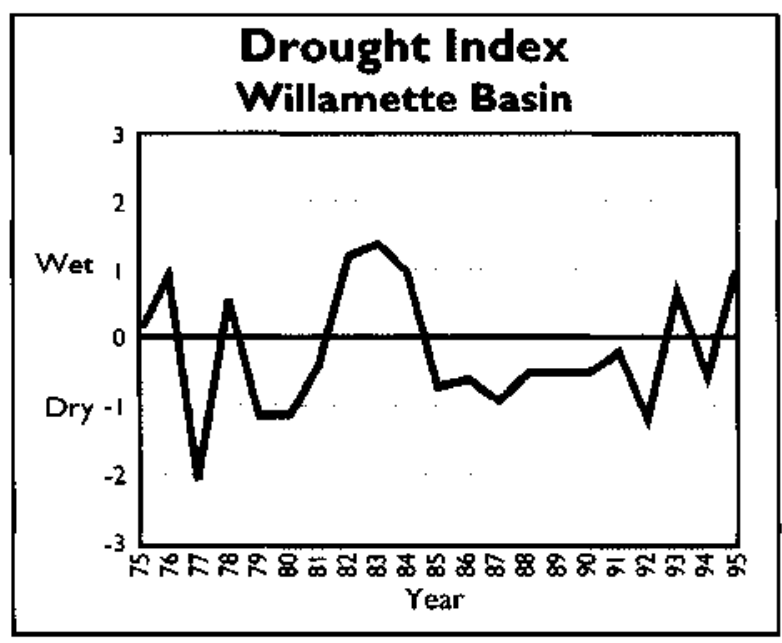

In the Willamette Valley, wet and dry periods have fluctuated in 10- to 20-year cycles during the last century; 1985 to 1994 was a period of drought Source: Surface Water Supply Index, Natural Resources Conservation Service. 
pearance in spring or early summer of dead lateral branches, dead tops, or entire dead trees (particularly Douglas-fir) can be alarming. The primary cause of damage is water stress in the tree resulting from drought in the previous year or accumulated over several years. The water stress reduces the tree's ability to defend itself against insects and pathogens. Damaged trees are most common in urban areas on the fringe of forested areas, in overstocked stands, on compacted or disturbed soils, and on droughty or shallow soil types. Such damage was particularly noticeable during the late 1980s and early 1990s, a period of drought in the Willamette Valley. Similar observations were documented in the 1950s and the 1970s.
Winter weather kills needles or tree tops - Winter drying of needles is common on Douglas-fir in the northern end of the Willamette Valley and in the Columbia Gorge, where dry, easterly winds and sunny weather cause water loss from needles to exceed water uptake by roots. Needles often dry out and fall from the tree in late winter and early spring. Although the damage is highly visible, the buds usually are not damaged and new growth resumes in spring.

Low temperatures alone can kill needles, buds, twigs, or inner bark. Large trees, particularly Douglas-fir and ponderosa pine, are often topkilled when low temperatures follow an unseasonably warm period. In the November 1955 "deep freeze," and again to a lesser extent in the winter of 1985 , widespread topkill was reported throughout the Willamette Valley. Mortality and other symptoms of low temperature injury often do not show up until one or two growing seasons after injury.

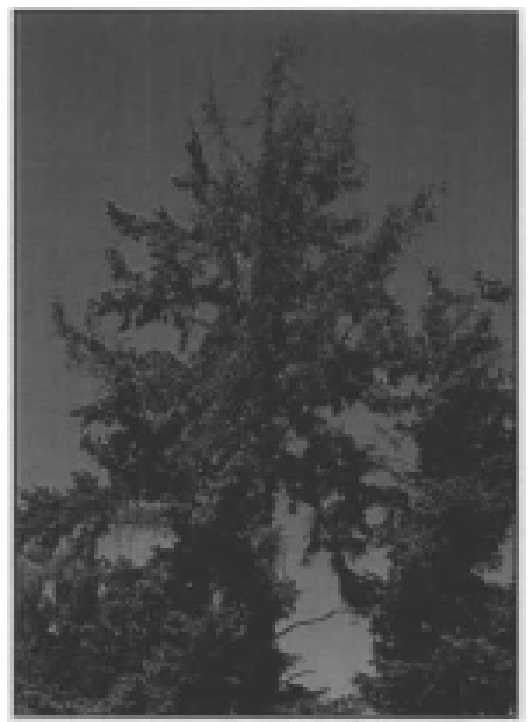

Sudden low temperatures after a warm period in winter can kill the tops of large, exposed trees, especially Douglas-fir. the lower main trunk are the last to die, and often remain living even though aboveground parts are dead.

\section{Douglas-fir on droughty soils show typical symptoms of canker diseases after a very dry year.}

Symptoms of Moisture Stress. Trees respond to moisture stress in several ways. Under moderate stress, stem and root growth are reduced. As stress increases, trees become increasingly susceptible to certain insects and diseases, particularly canker diseases and twig beetles. Under severe drought, water content in the tree may drop so low that the entire tree or portions of it may die. Roots 


\begin{abstract}
Oregon White Oak
Oregon white oak is threatened by development and fire exclusion-Oregon white oaks are one of the hallmarks of the Willamette Valley. They are ecologically important as food for many wildlife species, especially acorn woodpeckers and wild turkeys. In addition to threats from agriculture, urbanization, and exclusion of fire, white oak is host to a plethora of insects and diseases; fortunately, few threaten its survival.
\end{abstract}

The most visible and periodically damaging insect is the western oak looper, which defoliates trees over large areas. The present outbreak has persisted for at least the last 5 years. Populations of this insect near the Dallas area have been so high during the past 4 years that the loopers have defoliated the tops of other hardwoods and Douglas-fir growing in association with the oak.

Armillaria root disease attacks Oregon white oak and is often associated with tree uprooting in urban areas. White oak is adapted to droughty summers, and summer irrigation in urban areas and parks seems to contribute to the development of armillaria root disease.

\section{Ponderosa Pine}

Native pine is disappearing from the Willamette Valley-Ponderosa pine was once abundant in the southern part of the Willamette Valley, but urbanization, logging, and fire exclusion have diminished its population to small scattered patches of trees, especially in the northern part of the Valley. Natural regeneration has decreased, primarily because fire no longer creates seedbeds and removes competing understory vegetation.

Genetically different from eastern Oregon Ponderosa pine, Willamette Valley ponderosa pine has few major pests when grown in the Valley. The ponderosa pine cone beetle attacks young cones and compromises natural regeneration. In larger trees, pine bark beetles can attack and kill moisture-stressed pines, particularly in drought years and in overstocked stands. Foliage diseases periodically plague eastern Oregon ponderosa pine planted west of the Cascade Range, especially in areas with persistent fog.

\section{Exotic insect damages grand fir-The}

balsam woolly adelgid is a minute aphid-like insect that sucks sap from true fir trees and excretes a waxy "wool" that gives it its name. Introduced to the west coast early this century, this often overlooked pest has tremendous effect on the growth and seed production of grand fir and likely is responsible for decreases in grand fir populations at low elevations in the Willamette Valley.

\section{Hybrid Poplar}

Poplar is host to a recently introduced foliage disease-Since 1980, commercial hybrid poplar plantations have rapidly expanded in the northern Willamette Valley and along the Columbia River in Oregon and Washington. In 1991, two new species of melarnpsora leaf rust were reported from plantations near Scappoose, Oregon, and Woodland, Washington. These particular rusts are considered the most economically important poplar leaf rusts in the world. As of 1995, one of these rusts has become established in the Pacific Northwest, and the other (Eurasian poplar leaf rust) has not. Hybrid poplar clones resistant to these and other diseases are being developed continually. 


\section{EASTERN CASCADES (M242C), MODOC PLATEAU (M26IG),AND BLUE MOUNTAINS (M332G)}

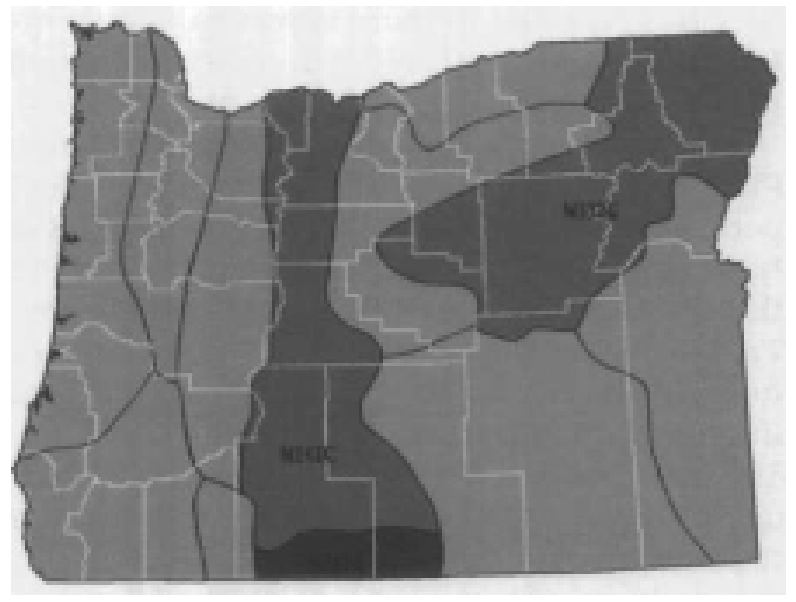

\section{Ecology}

The Eastern Cascades and Modoc Plateau-This region comprises the eastern slopes of the Cascade Range and the dry volcanic area at the southern end of the eastern Cascades. The eastern Cascades include several high volcanic peaks: Mount Hood, Mount Jefferson, and the Three Sisters, all with elevations over 10,000 feet.

The mixed conifer forests of this area are very complex and variable in terms of species composition and structure. Typically, mixed conifer stands on moist sites are characterized by a sparse overstory of large ponderosa pines and Douglas-firs, and a dense understory composed primarily of true firs with fewer lodgepole pine, occasional western larch, and western white pine. Historically, these stands were predominantly pine, maintained by frequent, low-intensity ground fires.

On dry sites, the structure and species composition are simpler, normally consisting of only two species (white fir and ponderosa pine) in a distinctly two-storied arrangement with large pines in the overstory. The most common pine species in this area are ponderosa and lodgepole. Each species covers a large area where it is the dominant climax species. Less common are the five-needled pines, including western white and sugar pines.
The Blue Mountains - Two major mountain ranges dominate the Blue Mountains region, the Blue Mountains in the center and southwest and the Wallowa Mountains in the northeast. Wide, low valleys separate the mountain ranges and channel two major rivers, the John Day and the Grande Ronde. The eastern boundary of this region follows the Snake River through Hells Canyon, separating Oregon and Idaho. Elevations range from 1,000 to 10,000 feet.

Conifer forests are the dominant vegetation at middle elevations in the Blue Mountains. The forests range from spruce and fir at higher elevations to mixed conifers (grand fir, Douglasfir, lodgepole pine, western larch, and ponderosa pine) at mid elevations to ponderosa pine at lower elevations. Important hardwood species, such as black cottonwood, quaking aspen, and willow, as well as many rare, endemic plant species, are concentrated in wetlands and riparian areas. Fire frequency once determined the composition of low and mid elevation forests in the Blue Mountains. Decades of fire suppression and selective logging of seral conifers (such as ponderosa pine and larch) have created forests that are more susceptible to disturbances from insects, diseases, and stand-replacing fires.

\section{All Species}

Drought, wind, and severe winters injure trees-Precipitation patterns are a key driving force for determining the character of the forested vegetation on the east side of the Cascade Range and the Blue Mountains. Moisture, falling as rain or snow in the spring and fall, is abundant at upper elevations but decreases rapidly with decreasing elevation. Summers are usually very dry throughout the area, especially at the lower elevations.

Various weather-related events common to this area are important to forest health. Periodic droughts reduce the capacity of trees to protect themselves against insects such as bark beetles and defoliators; large-scale outbreaks often occur during dry periods. Dry years from the mid to late 1980 s to the mid 1990 s contributed to widespread tree mortal- 


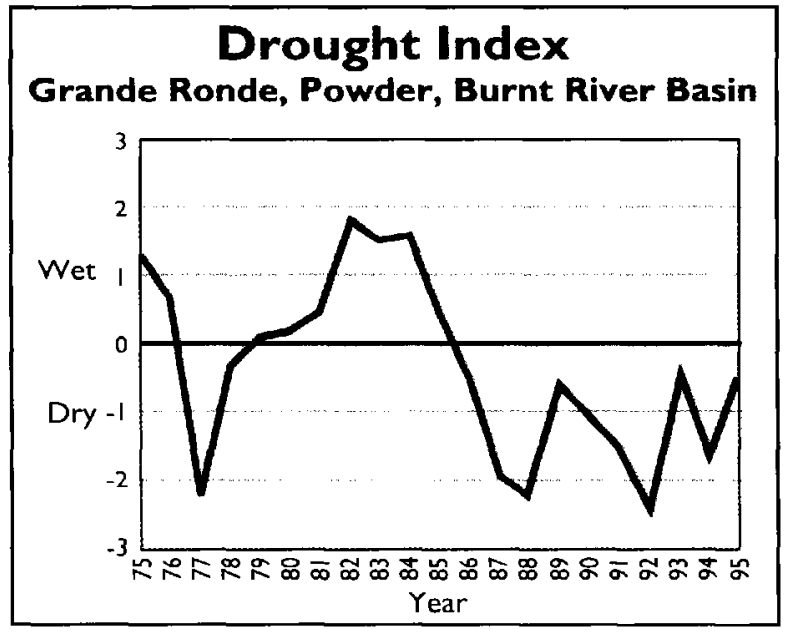

The last 10 to 12 years have been drier than average in eastern Oregon. In this drought index for the Blue Mountains, below zero represents drier than average years, and above zero is

wetter than average. Source:SurfaceWater Supply Index, Natural Resources Conservation Service.

ity on dry sites, particularly where stands were overstocked. Windstorms can cause stem breakage and windthrow, which increases stem decay in wounded trees and leads to bark beetle buildup in windthrown trees. In the Blue Mountains, severe winter storms often cause extensive snow breakage or windthrow in localized areas. Floods and ice jams frequently damage trees growing in riparian zones or on flood plains.

Fire suppression changes forests-Natural fire has played an important role in mixed conifer and ponderosa pine forests. In the lowelevation mixed pine and fir forests, frequent low-intensity fires maintained stands at low tree densities. At higher elevations, fires were less frequent but of higher intensity, often leading to removal of the entire stand. With the suppression of the low-intensity ground fires, stands have become extremely dense and now contain a large proportion of species such as true firs that are particularly susceptible to insects, diseases, and stand-replacing fires.

Dwarf mistletoe is more severe where fire is suppressed-Many conifer species east of the Cascades are infected by dwarf mistletoes, which are plant parasites. Before the 1900s, fires were frequent and reduced or eliminated dwarf mistletoe in many stands in the eastern Cascades and the Blue Mountains. For most tree species, fire suppression in the past century has resulted in more severe mistletoe infections, particularly when stands are unmanaged.

In the eastern Cascades and on the Modoc Plateau, Douglas-fir dwarf mistletoe is the most pervasive and damaging. Western larch also has high rates of mistletoe infection, despite the distances between host trees on stands. True firs, too, are affected by a dwarf mistletoe, but the effects on tree health are far less intense than in Douglas-fir and western larch. The combination of mistletoe infection and an opportunistic canker fungus often kills branch tips and produces a conspicuous flagging in infected true firs.

In the Blue Mountains, crown deterioration from dwarf mistletoe is the most important cause of western larch mortality in undis-

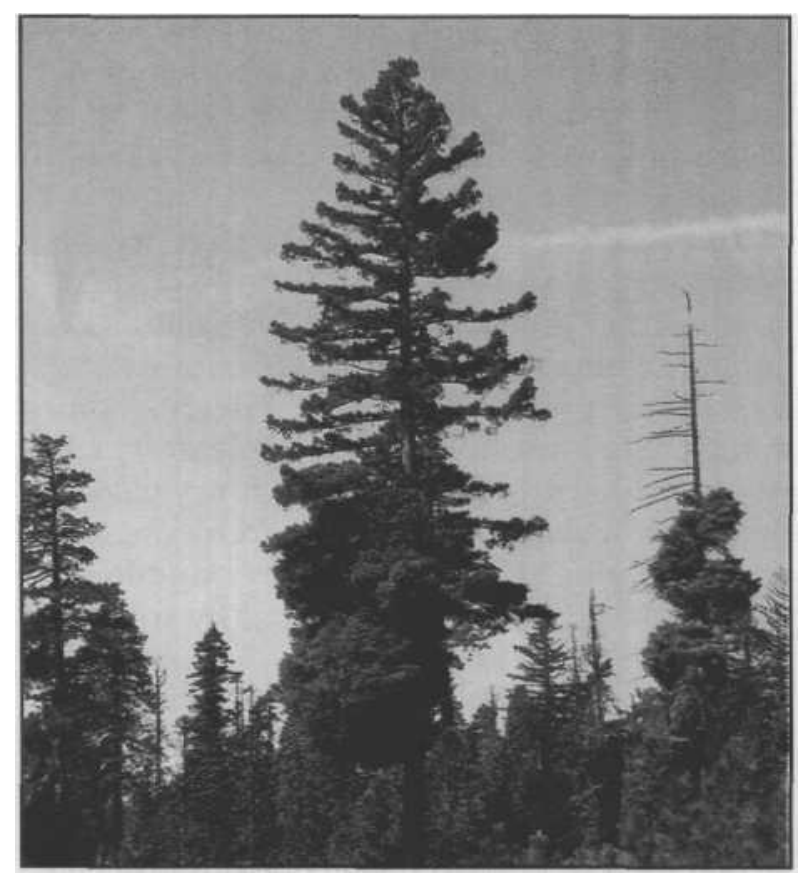

More than $40 \%$ of the Douglas-fir in eastern Oregon are infected with dwarf mistletoe, which causes growth loss, topkill, and mortality. Note the prominent brooms on the tree in the foreground and the killed tops on the trees in the background. 
turbed areas, where 38 to $51 \%$ of the larch in a stand might be infected. Where larch stands are managed, the removal of badly infected trees can reduce the amount of infection and increase vigor of the whole stand. Dwarf mistletoe is also common in Douglas-fir, ponderosa pine, and lodgepole pine. In pine, the most severe mistletoe infections tend to be in stands with a high proportion of pine and infrequent-fire histories.

\section{Mixed Conifers}

Western spruce budworm population collapses in mixed conifer stands-The most significant and persistent defoliating insect in eastern Oregon has been the western spruce budworm. Between 1980 and 1992, more than 400,000 acres of host type in central Oregon and more than four million acres in the Blue Mountains were affected by the budworm. This outbreak coincided with a drought that affected most of eastern Oregon. Douglas-firs, grand firs, and white firs were repeatedly defoliated at various intensities on the Ochoco, Deschutes, Wallowa-Whitman, Umatilla, and Malheur National Forests. Some of the defoliation effects included topkill, tree mortality, reduced growth, elimination of cone crops, and

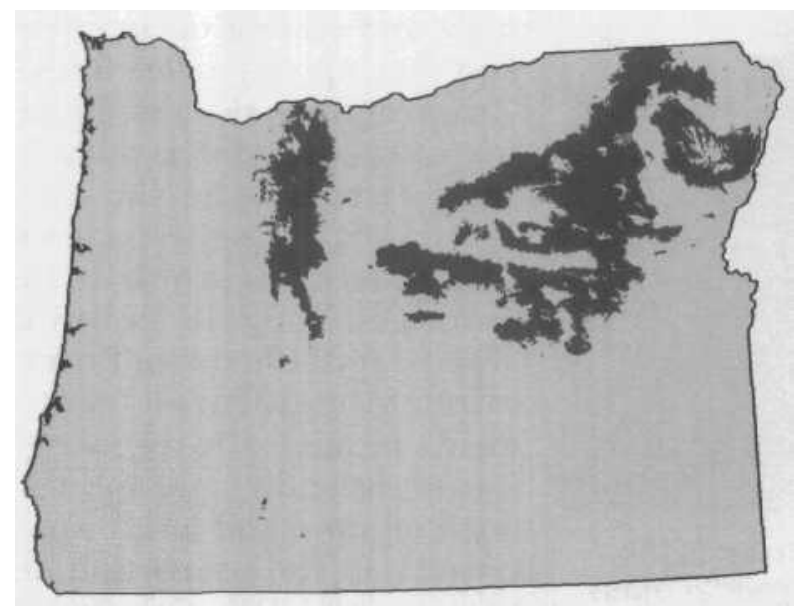

Western spruce budworm defoliation was apparent on almost all lands where the host species grew between 1980 and 1992.

Source: Cooperative Aerial Survey, Oregon Department of Forestry and USDA Forest Service. reduced resistance to other agents of mortality such as root diseases and bark beetles. In the most extreme cases (where the susceptible host type was most abundant), around $80 \%$ of the trees died. Spruce budworm populations collapsed region wide in 1992, and very little current defoliation is evident in this part of Oregon.

Bark beetles benefiting from crowding and drought-Several bark beetles have been important in eastern Oregon mixed conifer forests in the past decade: fir engraver, Douglasfir beetle, and western pine beetle. These insects are opportunistic and usually benefit from stress on the host tree resulting from crowding, disease, defoliation, or drought. Oldgrowth set-aside stands, where management activities are restricted, suffered high tree mortality. An unprecedented amount of fuels from insect-killed trees has accumulated during the last decade. The abundance of overstocked, low vigor, mixed conifer stands in eastern Oregon makes a repeat of the massive tree mortality in the 1980 s an eventual certainty.

One of the most conspicuous vegetation changes in southeastern Oregon was the massive white fir mortality in Lake and Kla-

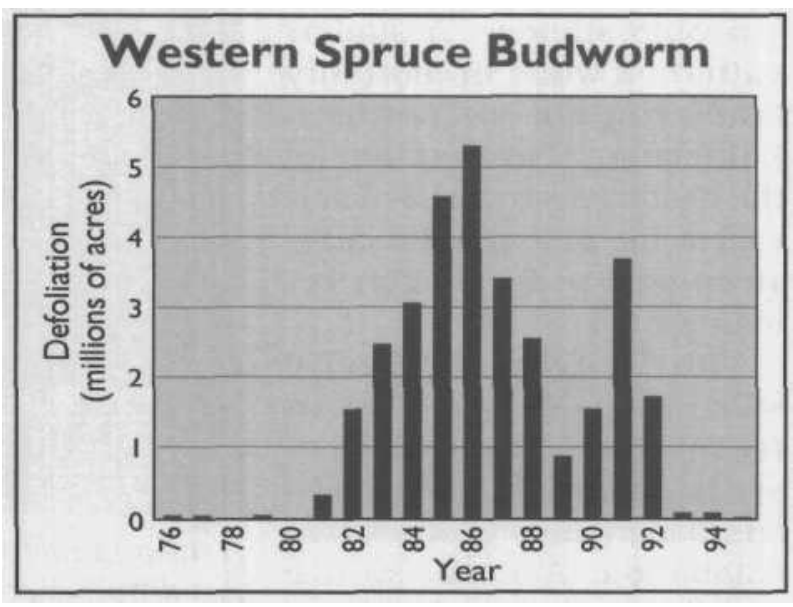

The number of acres affected by western spruce budworm in eastern Oregon peaked in 1986.

Source: Cooperative Aerial Survey, Oregon Department of Forestry and USDA Forest Service. 


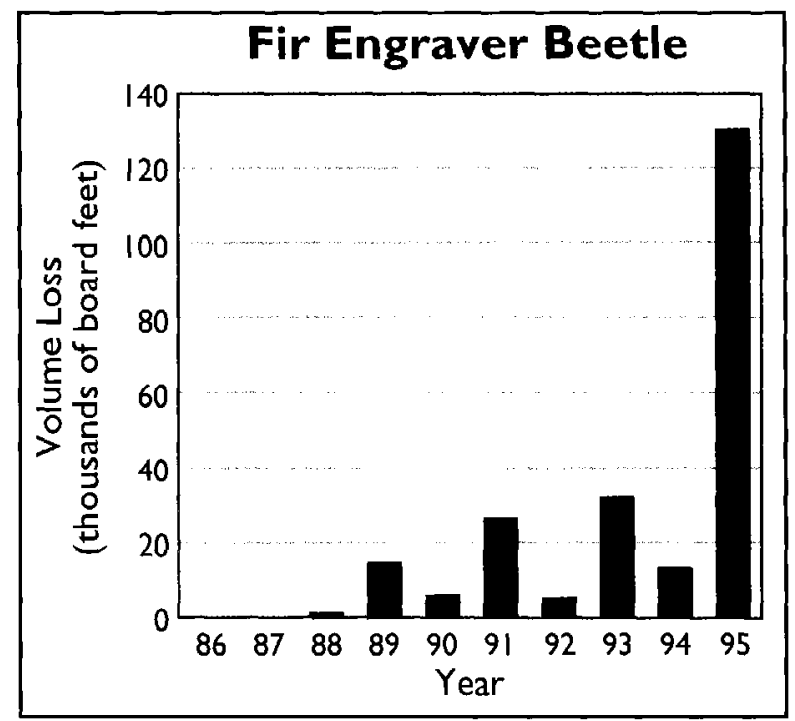

Mortality from the fir engraver soared in 1995; overstocking and drought are the underlying

causes. Source: Cooperative Aerial Survey, Oregon Department of Forestry and USDA Forest Service.

math counties. The cause is a fir engraver outbreak after several years of below-average precipitation. Much of the mortality was in overstocked stands at elevations below 6,000 feet. Before fire-suppression programs, most of these sites were dominated by ponderosa pine stands. A similar pattern of white fir mortality is affecting areas of northern California. Because few of the dead trees have been salvaged, the potential for catastrophic fire in Oregon remains high.

The Douglas-fir beetle killed thousands of trees in recent years, especially in areas where the host trees sustained heavy budworm defoliation. After the spruce budworm outbreak, these bark beetles have attacked and killed many of the trees weakened by several years of defoliation and drought. Characteristically, Douglas- fir beetles select the largest trees in the stand and thus have profound effects on stand structure. These effects have been most notable in recent years on the Sisters Ranger District (Deschutes National Forest), the Warm Springs Indian Reservation in the eastern Cascades, and the Malheur, Umatilla, and Wallowa-Whitman National Forests in the Blue Mountains.

Shifts in tree species cause increased root disease-Root diseases cause subtle, but persistent growth loss and mortality in mixed conifer stands. When disease pockets are small and scattered, they often increase the structural diversity and benefit wildlife and understory plants. Large rootdisease pockets in areas designated for timber management cause significant economic loss and increase fuel loading.

Root disease has increased in mixed conifer stands as host species have increased. Fire exclusion has resulted in less pine and larch, species more resistant to root diseases, and greater numbers of the more susceptible Douglas-fir and true fir. Partial cutting of mature trees in root disease areas, a common management practice, can intensify

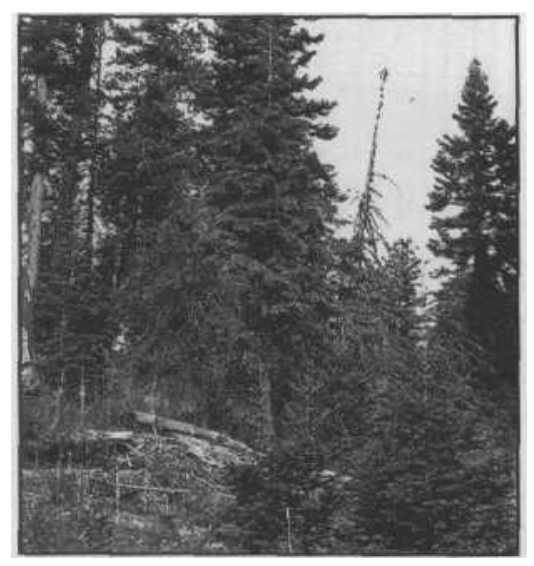

Armillaria root disease is the key disturbance agent in many mixed conifer stands. Trees weakened by soil compaction, drought, and overcrowding are very susceptible to armillaria. root disease problems. Root disease fungi colonize the roots and stumps of cut trees and then spread to live trees. Partial cutting also results in natural regeneration of susceptible species in the diseased area. Disease centers will remain a problem in managed mixed conifer stands until the use of fire or other silvicultural treatments promote the regeneration of resistant seral species such as pine and larch. Increases in the proportion of true fir and Douglas-fir in mixed conifer stands have led to increases in armillaria and annosus root diseases and laminated root rot. 

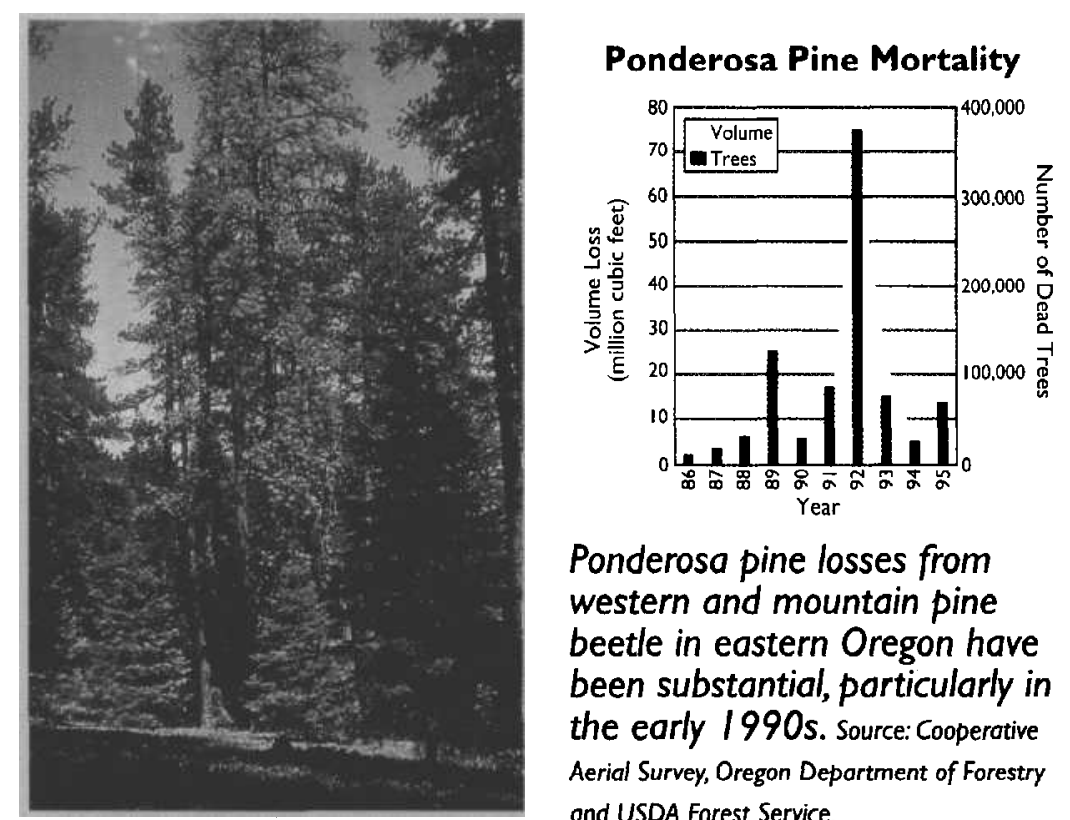

Ponderosa pine losses from western and mountain pine beetle in eastern Oregon have been substantial, particularly in the early 1990s. Source: Cooperative Aerial Survey, Oregon Department of Forestry and USDA Forest Service.

Old ponderosa pine is killed by pine beetles. Western and mountain pine beetles have been important mortality agents of ponderosa pine in pine and mixed conifer stands, in connection with drought and high stand densities resulting from the suppression of natural fires. On the Fremont National Forest, more than 14,000 large pines were killed in 1992, and another 18,000 in 1994. Throughout eastern Oregon, losses have been significant because old, yellow-barked pines are underrepresented across the forested landscape and the "oldgrowth" character of mixed conifer stands is drastically altered by the loss of larger overstory trees. ern spruce budworm. Seed production is thus inadequate for either natural regeneration or nursery-grown seedlings.

\section{Pines}

Distribution of pine is affected by fire - Ponderosa pine once covered large areas of the Blue Mountains and the eastern Cascades that are now mixed conifer forests. Disturbance from fire played a crucial role in maintaining the dominance of ponderosa pine and stand health by reducing tree densities. Fire suppression in pine stands results in higher densities, reduced tree vigor, and greater susceptibility to bark beetles, particularly in places where pine forests intergrade with desert, like the southern flank of the Blue Mountains. Lodgepole pine is an important seral species that colonizes disturbed sites in the grand fir zone in the Blue Mountains and frost prone areas in central

\section{Western Larch}

The greatest threat to western larch is the lack, of forest disturbance-Fire suppression and partial cutting maintain forest floor conditions that prevent larch from successfully regenerating. In the absence of disturbance, larch stands are gradually taken over by species more shade-tolerant than larch, such as grand fir and Douglas-fir. Only the re-introduction of fire or periodic mechanical disturbance can create the proper seedbed for larch. Furthermore, larch seed crops are usually poor because of dwarf mistletoe infections, frost damage to conelets, and feeding by west-
Oregon. Although it is an aggressive colonizer, it can be replaced by shade-tolerant species such as grand fir in the absence of fire. In areas dominated by lodgepole pine but with infrequent fire, dwarf mistletoe has a significant effect on stand vigor.

Mountain pine beetle is still evident in lodgepole pine - In eastern Oregon, the most conspicuous incidence of bark beetle activity in pines has been mountain pine beetle in lodgepole pine. Although outbreaks of this species are infrequent - every 60 years-they always kill the largest trees in the stand and produce enormous quantities of fuel. In cen- 

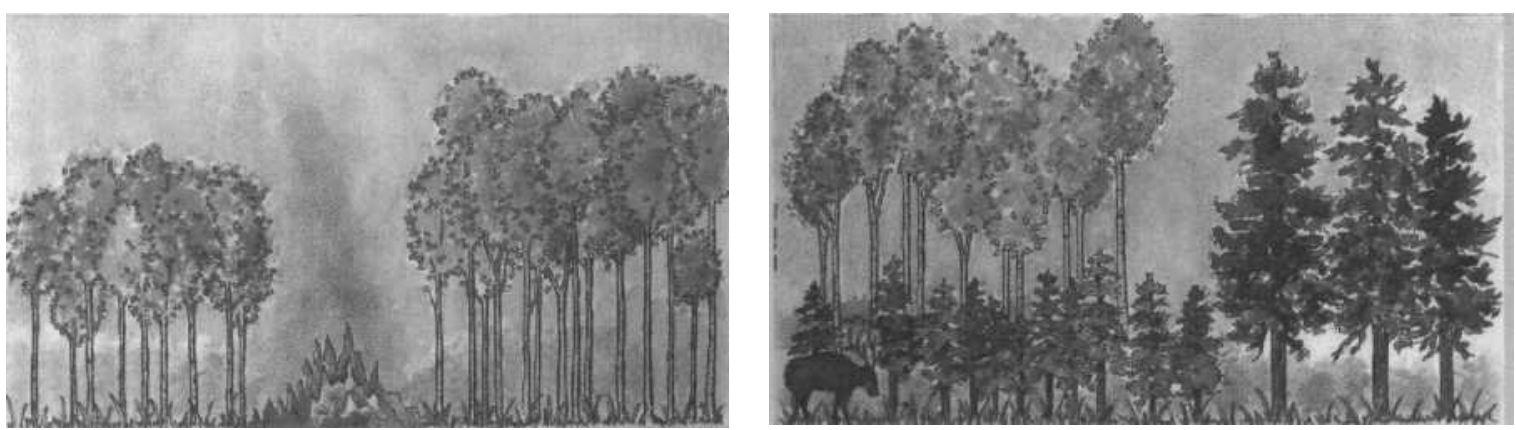

Aspen groves that have been burned (left) can successfully regenerate by sprouting from roots of burned, killed trees. Aspen declines and other species encroach where fire is suppressed (right).

Artwork by Beverly Swanson.

Cottonwood and aspen groves are disappearing. Two shade-intolerant hardwoods, quaking aspen and black cottonwood, have declined as a result of cattle and sheep grazing, an increase in big game, exclusion of natural fires, and encroachment of conifers. Regeneration of aspen requires fire to stimulate sprouting from roots and to eliminate competition from conifers. Cottonwood depends on flooding to control competing vegetation and prepare suitable seed beds for regeneration; it also sprouts from roots after fire.

These hardwoods are extremely important in riparian communities. They provide streamside stability, shading, water temperature regulation, and wildlife habitat. Although not abundant, quaking aspen is an important component of the eastern Oregon landscape. Over the past century, the extent of aspen stands has declined in central Oregon alone by about $50 \%$.

tral Oregon, an areawide infestation in the 1980 s, covering more than 500,000 acres, killed virtually all trees more than 8 inches in diameter in pure stands of lodgepole. This outbreak ended in 1989, although some areas, on about 50,000 acres along the Cascade Lakes Highway near Bend, are still experiencing significant mortality in lodgepole pine.

In the Blue Mountains, the last major outbreak of mountain pine beetle was in the 1970s, affecting almost one million acres. Although mountain pine beetle mortality has decreased since the 1970s outbreak, lodgepole stands will again stagnate and set the stage for another beetle outbreak unless active management is initiated to control tree densities.

\section{Various Species}

Some insects and diseases are of local or diminishing importance. Root diseases (annosus, black stain, and armillaria) are locally important on ponderosa pine in eastern Oregon. Engelmann spruce, important in riparian stands, is often infected by tomentosus root and butt rot, which makes it susceptible to windthrow and spruce beetle attacks after windstorms. The Douglas-fir tussock moth outbreak that peaked in 1993, affecting 46,000 acres in the Blue Mountains, subsided in 1995. Similarly, the pandora moth outbreak on lodgepole and ponderosa pine in central Oregon peaked in 1994 and has collapsed in 1996. 


\section{SOUTHERN CASCADES (M26ID) AND KLAMATH MOUNTAINS (M26IA)}

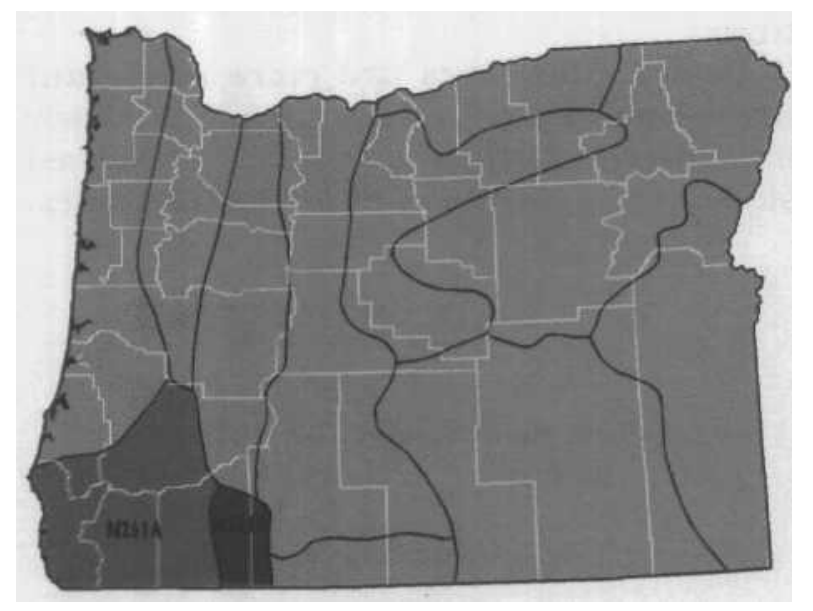

\section{Ecology}

Southwestern Oregon is one of the most diverse regions in the United States. Geology and soils are extremely varied. Elements of the California, north coast, and eastern Oregon floras combine with many species indigenous only to the Klamath Mountain region. During periods of climate change, plants from as far south as Mexico and as far north as the Arctic established in the area and mixed with endemic species. Plants and animals continue to migrate north and south along the Cascade/ Sierra and Coast ranges and east and west across links in the ranges. Species such as mountain mahogany, sagebrush, and quaking aspen reflect the area's importance as an eastwest axis, and Pacific silver fir and Alaska yellow-cedar reflect north-south movement. Sierran pine and shrub species are also common. The area has been the site of local development of ancient conifers including yew, cypress, and redwood.

Forest vegetation in interior valleys of the Rogue and Umpqua rivers and lower elevations of the Cascade Range and the Siskiyou Mountains includes drought-tolerant conifers and hardwoods such as ponderosa and sugar pines, California black and Oregon white oaks, and Pacific madrone. Mid elevations include Douglas-fir, white fir, tanoak, and chinkapin.
Higher elevations are dominated by true firs and mountain hemlock. The Siskiyou Mountains also contain large areas of soils that support Jeffrey pine, Port-Orford-cedar, and unique associated flora.

Southwestern Oregon has a mediterranean climate, with generally mild, wet winters and warm, dry summers. Most precipitation is from November to March. Summer thunderstorms are common. Annual precipitation ranges from slightly less than 20 inches in interior valleys to 120 inches at higher elevations. The late 1980s and early 1990s was a period of below-average rainfall. The area has the greatest temperature extremes in western Oregon. In summer, it is often the warmest part of the state.

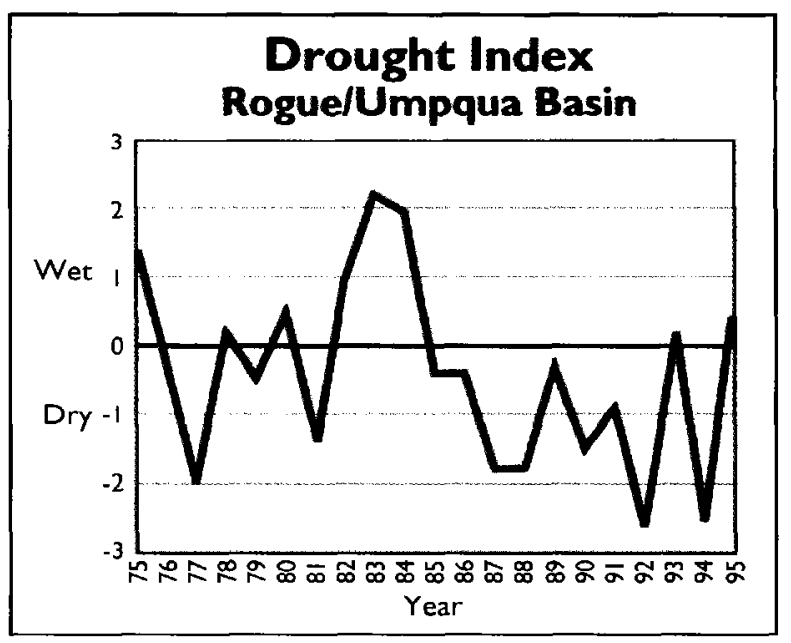

Southwestern Oregon has experienced a drought over the past decade. This drought index graph shows years that are drier than average (below zero) and years that are wetter than average (above zero). Source:SurfaceWater Supply Index, Natural Resources Conservation Service.

\section{All Species}

Past and present fires influence vegetation-Historically, fire has played a critical role in shaping vegetation. At low to mid elevations, frequent, low-intensity ground fires were once common. Fire frequencies ranged from 15 to 50 years in the Klamath Mountains. In interior valleys, the fire-return interval was prob- 
ably 8 to 10 years, resulting in a pine-dominated forest with few snags and little woody material on the forest floor. In recent decades, the fire regime has shifted toward infrequent high-intensity, stand-replacing fires. Fire exclusion has resulted in substantial increases in stand densities and higher proportions of less fire-tolerant species. At high elevations, infrequent, low- to moderate-intensity ground fires were common historically. Now, high-intensity, stand-replacing fires are more common.

Root diseases hove subtle but significant effects on growth and survival-Several native fungi cause root diseases in southwestern Oregon. Of particular importance are laminated root rot, armillaria, and black stain root diseases. Most root diseases are diseases of the site. Inoculum of laminated and armillaria root diseases may remain viable in the wood of infected roots for 20 to 50 years. They cause growth loss and mortality in individual trees. Across the landscape, root diseases produce changes in forest species composition and structural diversity. They create canopy openings, alter vegetative succession, provide snags for cavity nesters and their associates, and contribute woody material to the forest floor

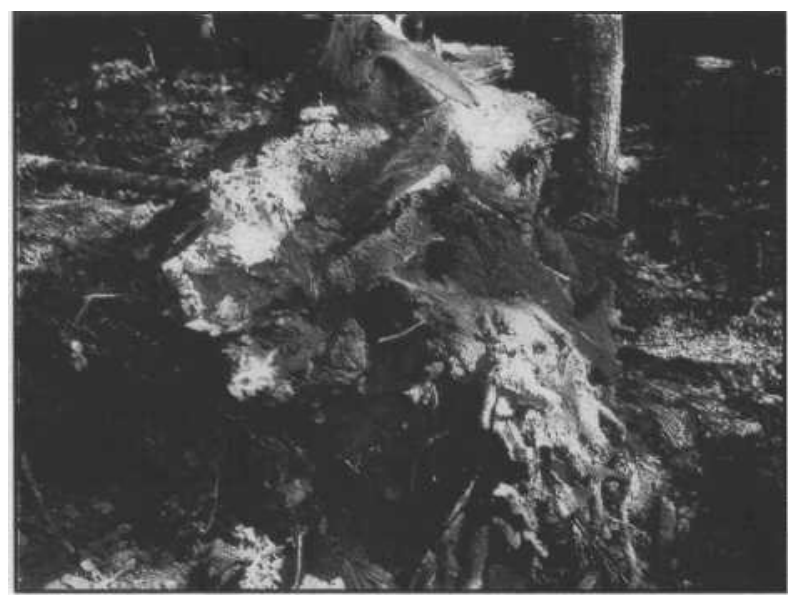

Root diseases (such as laminated root rot pictured above) are often overlooked because of the subtle nature of their effects; however, their long-term effect on growth and survival is much larger than that of virtually any other forest mortality agent and streams. Root diseases are managed by favoring resistant and immune species adapted to sites and by encouraging harvest practices that avoid reducing the vigor of individual trees.

Dwarf mistletoes are more abundant now-Dwarf mistletoes are distributed widely in southwest Oregon, especially on the east side of the Siskiyous and in the Cascades.

Lodgepole pine dwarf mistletoe.

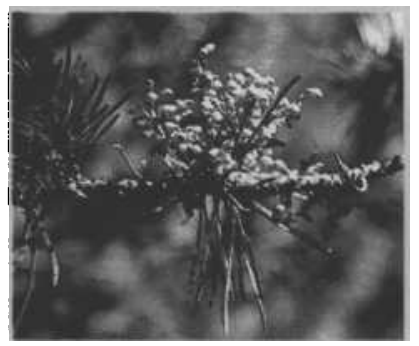

Dwarf Mistletoes. Dwarf mistletoes are parasitic plants that infect conifer species. Small, sticky seeds are forcibly discharged from female dwarf mistletoe plants and land on conifer needles. They are washed down to the branches where they germinate, invade the tree tissue, and draw water and nutrients from the host plant. Infection is favored by multilayered canopies of single species. Most dwarf mistletoes are highly host specific, infecting only one or a few tree species. Their effects on their hosts include growth loss, topkill, distortion, mortality, and predisposition to infection and attack by other agents such as bark beetles or decay fungi Dwarf mistletoe brooms are often occupied by nesting birds and small mammals. Managing dwarf mistletoe to provide wildlife habitat without sacrificing the vigor of the stand poses challenges for landowners and managers. Mistletoes will continue to be aggressively managed where heavily infected trees pose threats to human safety or where timber values are of primary importance. 
They are common on Douglas-fir, white fir, lodgepole pine, Jeffrey pine, western hemlock, and mountain hemlock and less frequent on ponderosa pine and other species.

Trees infected with dwarf mistletoes have been removed during timber harvest and stand cleaning in some portions of the region. Many areas, however, probably have more dwarf mistletoe-infected trees now than they had before fire exclusion. Where ground fires were once frequent, higher proportions of infected trees were killed because ground fuels and large brooms carried fire into the crowns. In many areas with selective harvests, healthy trees were removed, leaving behind infected trees, or heavily infected trees were removed and infection intensified in lightly infected trees when those trees were exposed to increased light.

\section{Port-Orford-Cedar}

Exotic pest kills Port-Orford-cedar on wet sites-Port-Orford-cedar grows from just north of Coos Bay, Oregon, into northern California in a narrow coastal strip. It grows on a wide variety of sites including streambanks, bogs, coastal sand dunes, deep productive soils, and dry sites. Port-Orford-cedar needs a consistent water supply and is an important species in riparian ecosystems. Its snags and logs are long-lived components of terrestrial and aquatic wildlife habitat. It has important cultural value to the indigenous people of northmarket is limited, for decades the export market for Port-Orford-cedar has been substantial, making it one of the most valuable species in North America.

In 1952, an introduced disease caused by a waterborne fungus, was reported within the native range of Port-Orford-cedar at Coos Bay, Oregon. Cedar mortality soon became conspicuous in coastal towns and along major roads. The fungus is now present throughout much of the range of PortOrford-cedar. Infested and healthy Port Orford-cedar are intermingled. Where the disease has been present for several decades, 


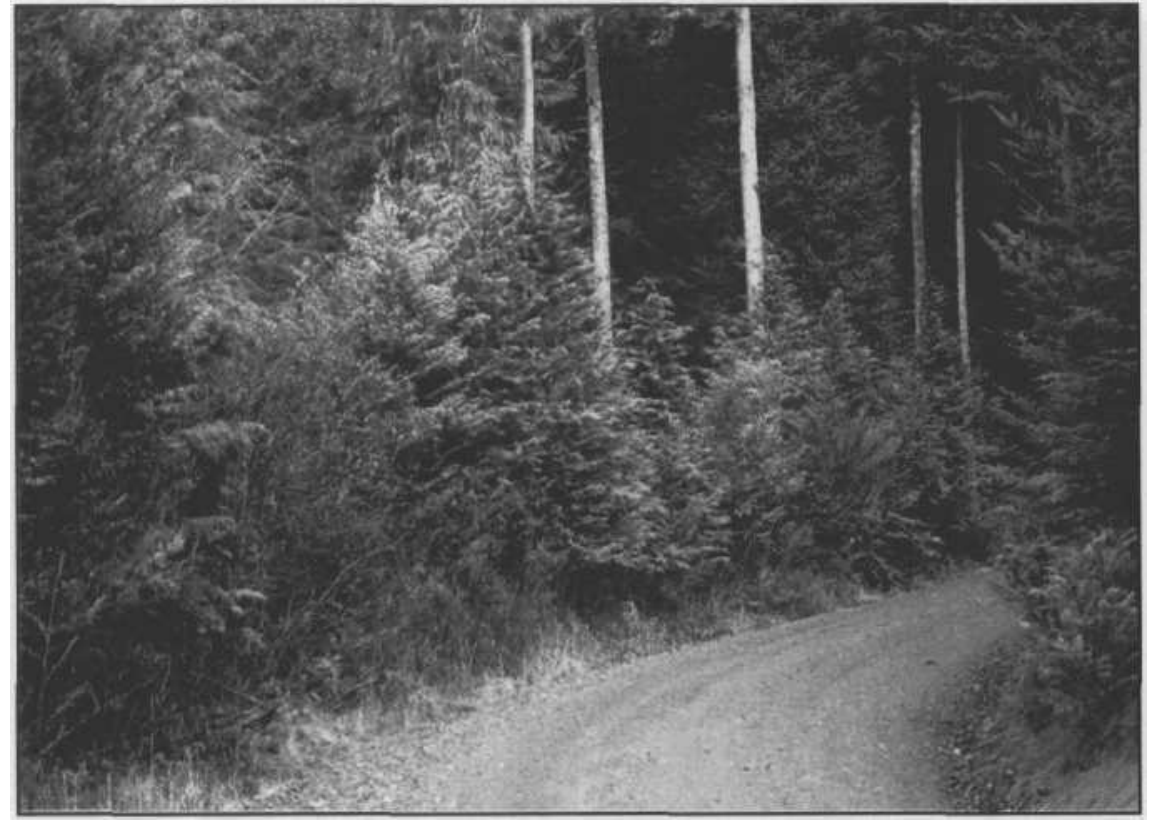

Port-Orford-cedar killed by Port-Orford<edar root disease is common along roads where the disease-causing fungus is spread in soil by vehicles and road construction.

mortality has been extensive, especially along streams and downslope drainage ditches. Mortality is less and often absent on drier microsites. An interagency and interregional coordinating group provides technical assistance on Port-Orfordcedar management for federal agencies.

Some of the strategies for controlling Port-Orford-cedar root disease include the following:

- Close roads and restrict operations to reduce movement of infested soil.

- Clean vehicles and equipment before entering or leaving specified areas to remove soil that may contain spores.

- Berm roadsides to reduce splash and runoff.

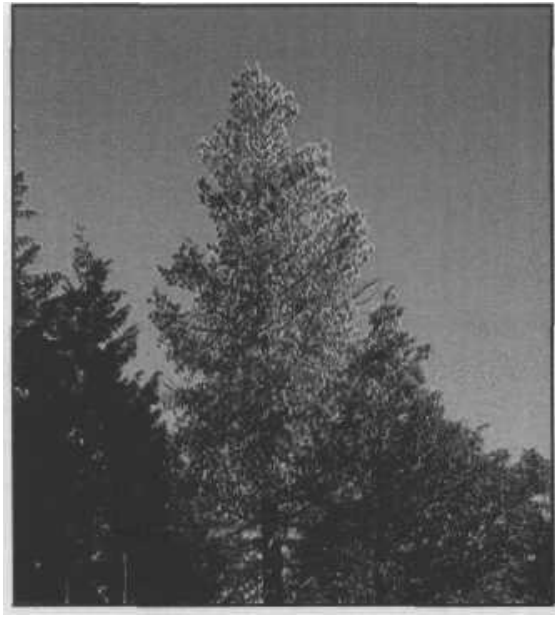

Big, old sugar pines, invaluable for their beauty and ecological function, are being killed by a combination of drought, overcrowding, bark beetles, and blister rust.
- Remove Port-Orford-cedar from roadsides to prevent infestation of disease-free stands.

- Identify resistant trees and breed them for resistance to the fungus.

- Retain Port-Orford-cedar in portions of stands where conditions are unfavorable for the disease.

Five-Needle Pines

Bark beetles and blister rust are killing five-needle pinesFive-needle pines, including sugar pine, western white pine, and whitebark pine, are declining throughout southwestern Oregon. Mountain pine beetles are killing large fiveneedle pines, especially those stressed by injury, disease, or intense competition. Recent high rates of beetle-caused pine mortality are due mainly to overly dense stocking caused by fire suppression, compounded by the recent decade of drought.

White pine blister rust affects all five-needle pines, causing topkill, branch mortality, and tree death. The disease has been in southwestern Oregon since the mid 1920s and many sites are conducive to infection because moisture, as clouds or fog, in the late summer and early fall allows rust spores to germinate and infect pines. Rates of infection and subsequent mortality are high in pine regeneration, and large infected trees are more vulnerable to bark beetle attack. 
Five-needle pines are important trees in southwestern Oregon. Western white pine and sugar pine are valuable because of their fast growth, ability to reach great ages and sizes, frost hardiness, and resistance to root disease. All three species have high scenic, wildlife, and watershed values. They contribute significantly to ecological diversity. In the absence of blister rust and mountain pine beetle, these pines thrive.

\section{Mixed Conifers \\ Bark beetle mortal-} ity is highest on dry, overstocked sites-Ponderosa pine, Douglasfir, and white fir mortality from bark beetles was particularly high in 1995, especially on dry, overstocked sites. Currently, drought and insects are replacing fire as primary regulators of site stocking. Such uncontrolled disturbances have serious drawbacks. For example, large ponderosa pines tend to be the first trees killed by bark beetles; such large trees are often important to meet management objectives. Extensive insect-caused tree mortality, particularly in multilayered stands, can create massive fuel buildups, which ultimately can contribute to large-scale, severe wildfires.

Landscape-scale assessment is becoming increasingly common for addressing drought-related mortality issues. Density-management projects are planned or underway in many overstocked stands. Treatments include thinning, prescribed burning, or a combination of the two. Treatment priorities are assigned by risk-rating systems that take into consideration stocking, elevation, proximity of insect activity, the urbanforest interface, and fire regimes.

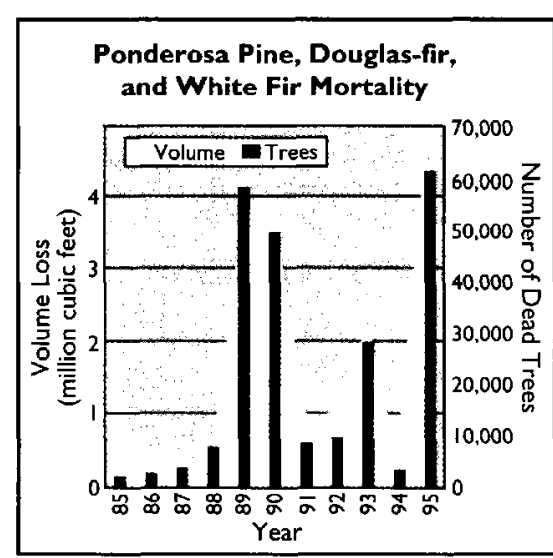

bark beetle mortality in southwestern Oregon has been high since the late 1980s. The prevalence of dense stands over extensive areas and a succession of extremely dry years have predisposed trees to insect attack.

Source: Cooperative Aerial Survey, Oregon

Department of Forestry and USDA Forest Service.

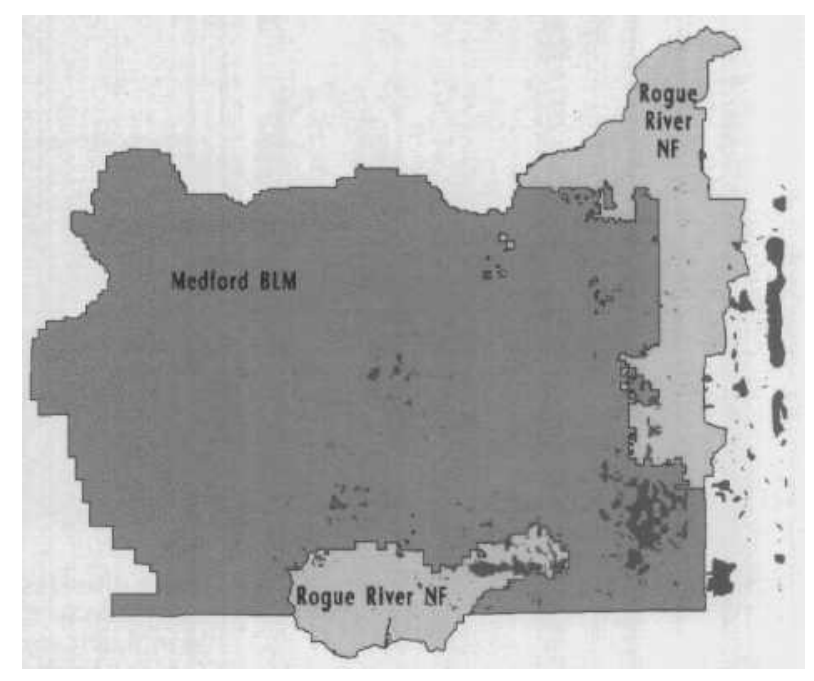

Locations of bark beetle mortality in all tree species on the Rogue River National Forest and Bureau of Land Management's Medford District

in 1995. Source: Cooperative Aerial Survey, Oregon Department of Forestry and USDA Forest Service. 


\section{995 FOREST DISTURBANCE IN WASHINGTON}

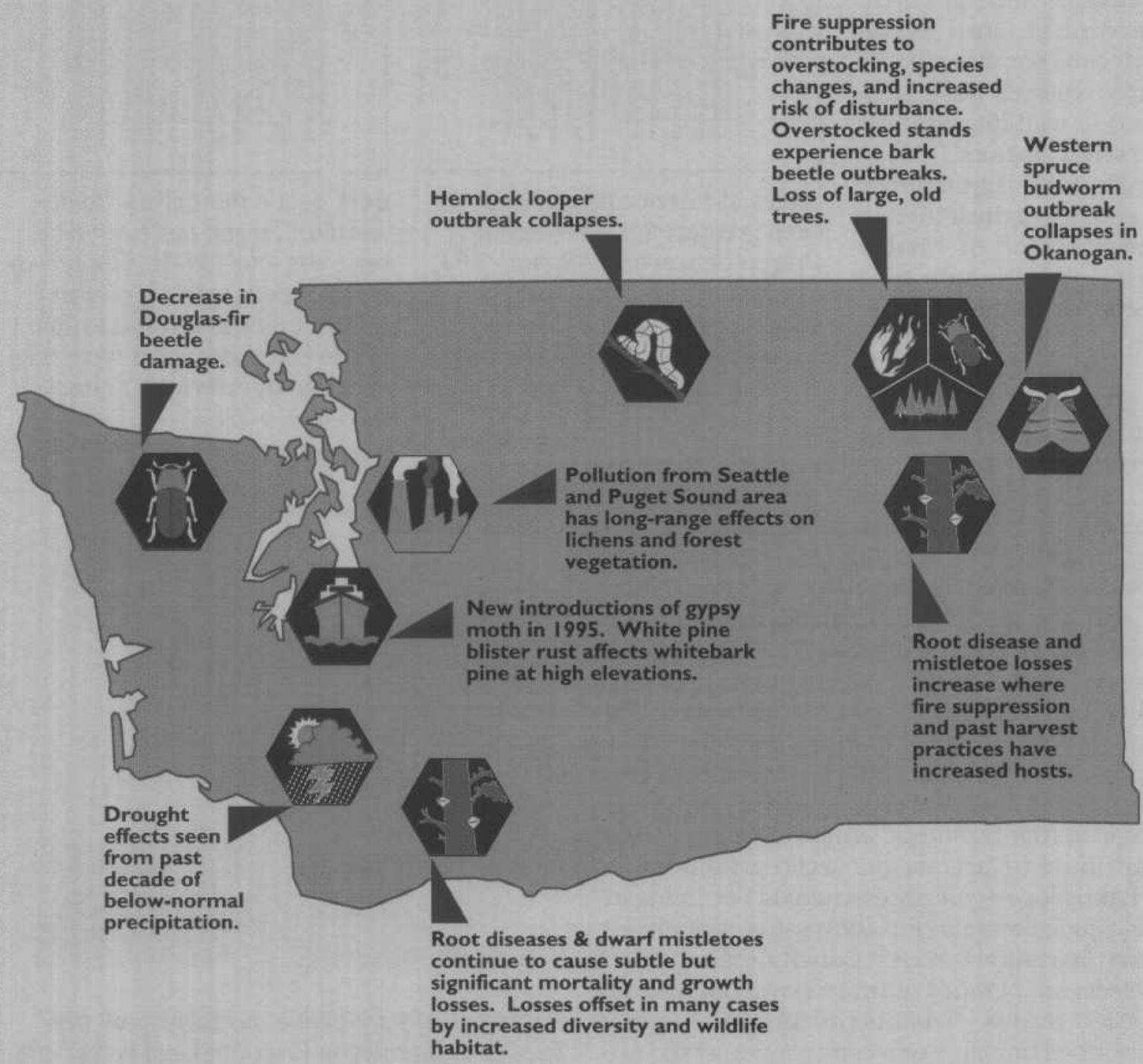

Washington -44 


\section{CHAPTER 3. DISTURBANCE AND FOREST HEALTH IN WASHINGTON}

\section{WASHINGTON COAST RANGE (M242A),WESTERN CASCADES (M242B),AND PUGETTROUGH (242A)}

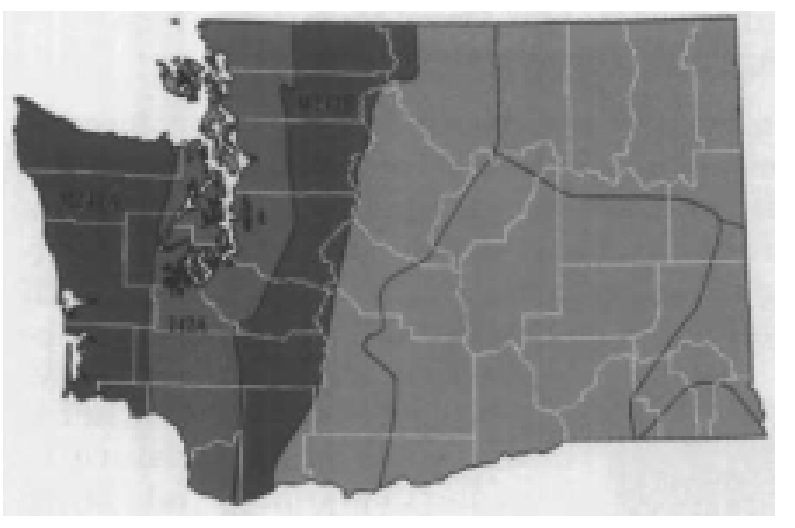

Washington Coast Range-The Washington Coast Range extends from the Olympic Mountains in the north southwards into Oregon. The Olympics, in the center of the Olympic Peninsula, are unusually high, with elevations up to 8,000 feet; many of the major peaks have active glaciers. Most other peaks are below 4,000 feet. Flat, coastal lowlands are extensive in some areas. Dunes and bogs are frequent along the coast, interspersed with headlands of more resistant rock.

Douglas-fir, western hemlock, Pacific silver fir, and western redcedar predominate on the higher mountain slopes. Forests of the lower slopes and the coastal fog belt are dominated by Sitka spruce and western hemlock. Precipitation is heaviest from November to April and averages 60 to 240 inches annually, some of the highest rainfall in the state. Severe winter storms cause landslides and windthrow. Stand-replacing fires burn at irregular intervals of 90 to 250 years.
The Puget Trough-The Puget Trough is the northern extension of Oregon's Willamette Valley. In the north, glacial activity has shaped the land and influenced soil composition. Elevation ranges from sea level to 2,000 feet. The dominant vegetation in this region is western redcedar, western hemlock, and Douglas-fir. Riparian species include cottonwood, willow, red alder, and bigleaf maple. Precipitation averages less than in the Coast Range, from 25 to 60 inches, although intense winter storms caused flooding at frequent intervals before dams were built.

Fires were commonly set by American Indians, trappers, hunters, and settlers. Early fires created and maintained prairies that stretchedintermingled with forests - from Tacoma to the Columbia River. Today, many of the original prairies have converted to forests.

The Western Cascades-The western Cascades region consists of steep mountain slopes, highly dissected by large rivers. Elevation ranges from near sea level at the Columbia River to higher than 14,000 feet at the peaks of the Cascade Range, although most of the region is between 2,000 and 7,000 feet. Low and mid elevations of the western Cascades are dominated by Douglas-fir and western hemlock, with western redcedar, bigleaf maple, and red alder common in drainage bottoms. As elevation increases, mountain hemlock, Subalpine fir, Pacific silver fir, noble fir, and Engelmann spruce increase in abundance. Western white pine is a minor stand component, and whitebark pine is common along the crest.

Precipitation ranges from 50 to 150 inches, falling as rain and snow during October to June. Summers are relatively dry. Fire periodicity is extremely variable, ranging from decades to centuries for major stand-replacing fires. Volcanos erupt periodically. 

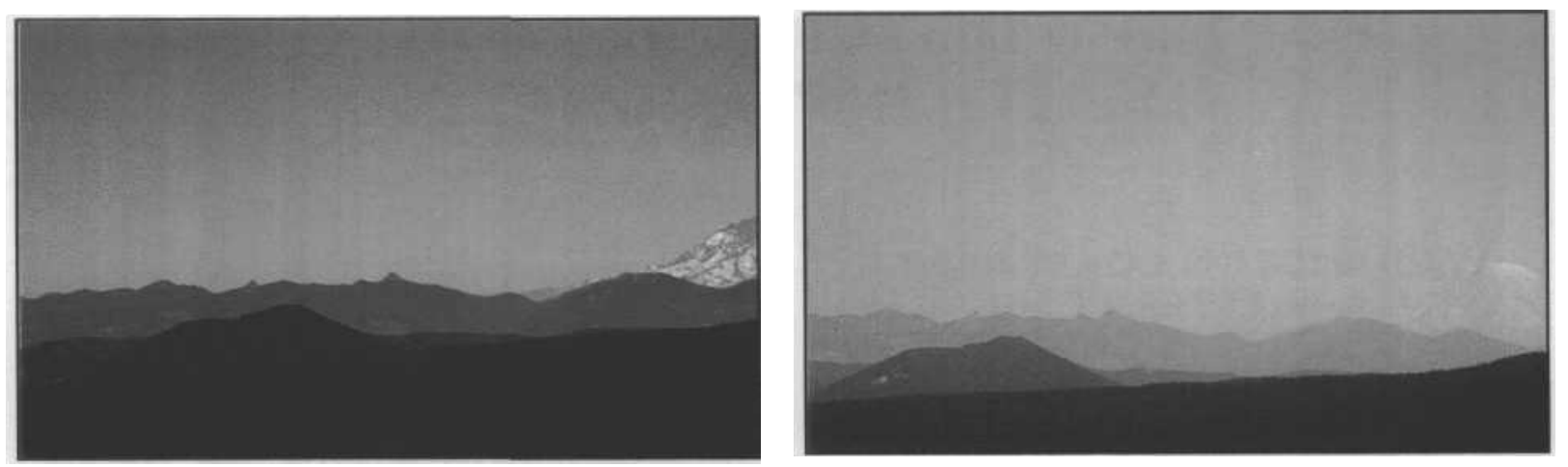

Pollution from the Puget Sound region can be seen at Red Mountain, near Mount Adams, more than 10 miles away. Days with little or no pollution (left) contrast with high pollution days (right).

All Species
Air pollution in Puget Sound has longrange effects-The population of western Washington is expected to increase in the future and, with it, the air pollution caused by automobiles and industries. Air pollution has

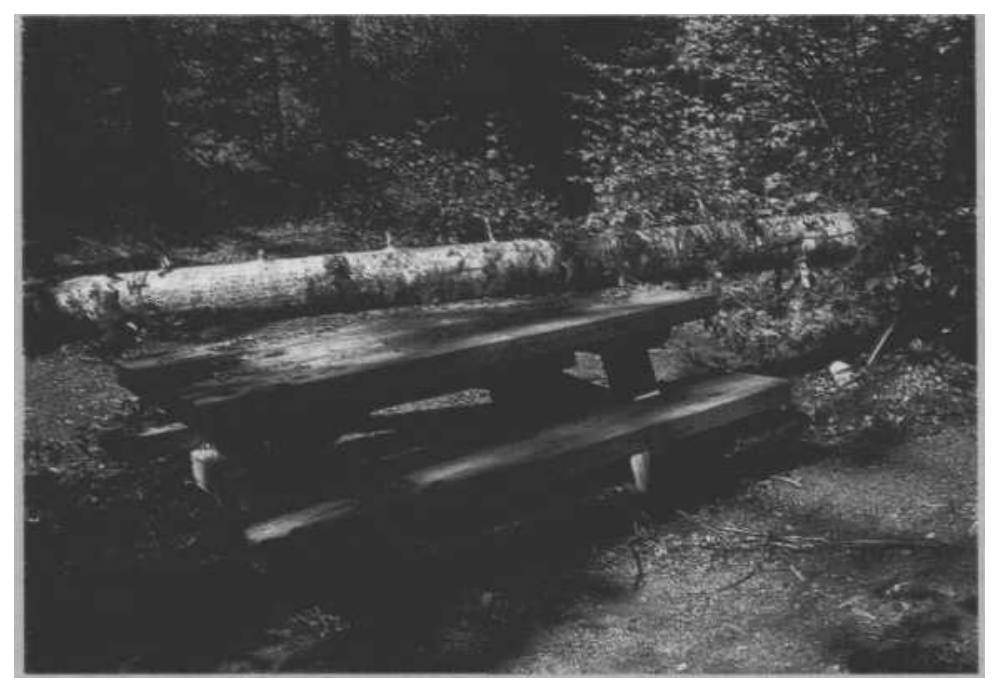

What is a "hazard" tree? A hazard tree contains some form of structural defect, a peculiar location, or a combination of both, giving it a high possibility of failing and causing injury to people or property. To be considered a hazard tree requires a valuable target-buildings, cars, or people-close to the tree. A rotten tree deep in the forest away from people is not a hazard because no target has been identified, but a rotten tree near a campsite, road, or home is a hazard. many adverse effects on Northwest forests. Ozone, a pollutant created from nitrogen oxides and volatile organic compounds (both byproducts of automobile emissions) and sunlight, damages a variety of plant species, with symptoms ranging from leaf spotting to decreased growth to mortality. Some plants, such as lichens, are much more sensitive to ozone than others and can be used as ozone indicators. In western Washington, the number of lichen species, as well as the concentration of pollutants in lichen tissue, are being monitored to identify forested areas with ozone damage.

Decayed trees are hazards in recreation sitesTrees with root disease and stem decays are potential hazards in recreation sites, particularly in stands where the trees are old. Homes being built among the trees in the urban-forest interface are at particular risk from decayed trees, which can fail without warning, damage homes, and injure or kill people. Efforts are being made to teach homeowners, landscape planners, highway department employees, park staff members, 
and other land managers to recognize and correct tree hazards. Corrective measures may include tree removal, tree replacement, or pruning. Planning so human activity areas are away from hazard trees can reduce risk without altering the trees.

\section{Douglas-Fir}

Effects of laminated root rot differ with site and use-Laminated root rot is widespread in southern British Columbia, Washington, Oregon, western Montana, and northern Idaho. It is believed to have co-evolved with its hosts, making it a natural part of many forest ecosystems. It neither destroys huge expanses of forest nor threatens the existence of host species, but it does cause subtle, persistent growth loss and mortality. The effect on its primary host, Douglas-fir, varies with the use or setting of the trees. When disease pockets are small and scattered, they increase the structural diversity and benefit wildlife and understory plants. Large root-disease pockets in areas designated for timber management cause significant economic loss. In settings such as parks, around homes, or along well-traveled roads, the disease can threaten life and property.

Douglas-fir beetle increases after disturbances-Douglas -fir beetle is the most impor-

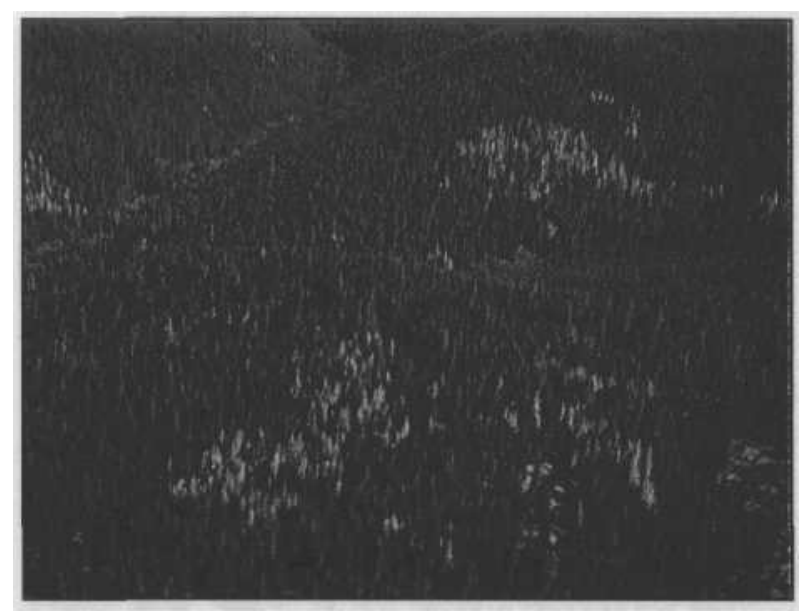

Douglas-fir beetle attacks large groups of Douglas-fir only when large amounts of food (downed trees) becomes available after windstorms, fires, or logging.

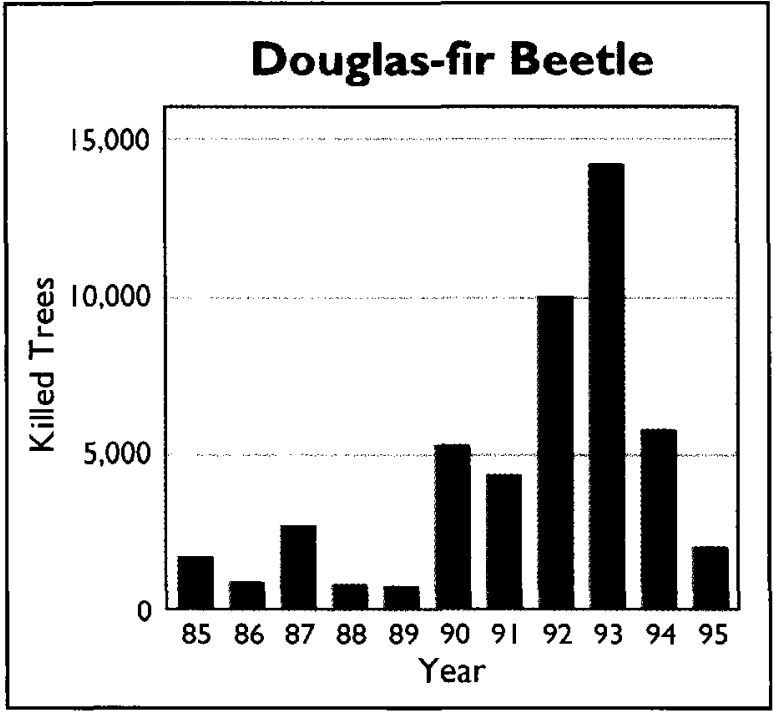

Douglas-fir beetle activity decreased in 1995 in

Western Washington. Source: Cooperative Aerial Survey,

Washington Department of Natural Resources and USDA Forest Service.

tant bark beetle of Douglas-fir. In western Washington, it attacks Douglas-fir 60 years old or older; low populations are always present. When populations are low, the beetle is relatively nonaggressive, attacking recently killed (windthrown, snow-broken) or dying (root-rot infected, defoliated, drought-stricken, firedamaged, wounded) trees. When many fresh logs become available in a short period, from such events as wind throw, fires, or logging, the beetles can reproduce in them and quickly reach outbreak populations. They can then attack and kill healthy trees. Relatively pure stands of Douglas-fir, 120 years old or older, of low vigor from competition, drought, or diseases, are most at risk from beetle attack.

The 1995 cooperative aerial insect detection survey reported more than 2,000 trees killed by Douglas-fir beetle on about 3,000 acres in western Washington, a three-fold decrease from 1994. Because aerial surveyors detect tree condition based on changes in foliage color, trees that quickly lose their needles may not be recorded.

Fog and off-site trees create an ideal environment for needle disease-Swiss needle cast is a native disease of Douglas-fir 


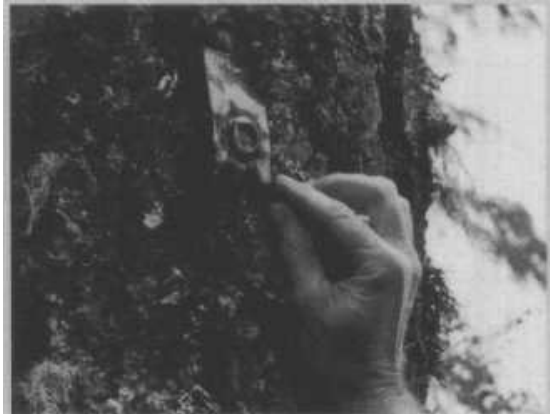

\section{"Bubble cops" containing MCH protect high-value trees from Douglas-fir beetle attack.}

How to minimize Douglas-fir beetle damage. Losses from Douglas-fir beetle may be reduced by promptly removing fresh logs from the forest Extensive winter windthrow must be removed before beetles emerge. Any standing, live trees that were killed during the initial attack on logs should be removed as well. Trees that have been dead a year or more are generally no longer suitable habitat and need not be removed. Salvage operations need to be carefully planned and executed in a timely manner. Tree tops and large limbs need to be piled or scattered away from standing green trees to prevent emerging beetles from attacking healthy trees. The experimental pheromone MCH, a Douglas-fir beetle anti-aggregant, could be used in the future in selected areas such as campgrounds to protect trees from attack. throughout the Coast Range and western Cascades. In most areas, the disease is of little consequence, causing premature shedding of 3 - and 4-year-old needles. Since the early 1980s, however, thousands of acres of Douglas-fir plantations in western Washington have shown increasingly severe damage from this disease. In late winter and early spring, diseased plantations appear noticeably yellow to brownish yellow, in contrast to the adjacent, green and vigorous natural stands. Individual tree symptoms include severe chlorosis (yellowing), poor retention of needles, and reduced height and diameter growth. With little foliage remaining for photosynthesis, tree growth declines, and some trees eventually die. The severity of symptoms differs considerably among individuals in the Douglas-fir population, indicating that tolerance to infection exists in the species.

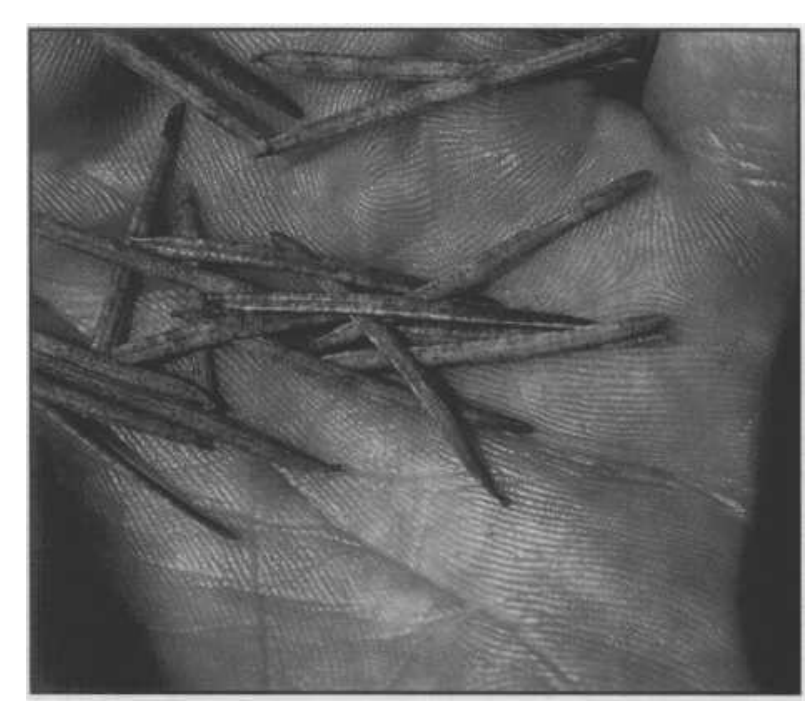

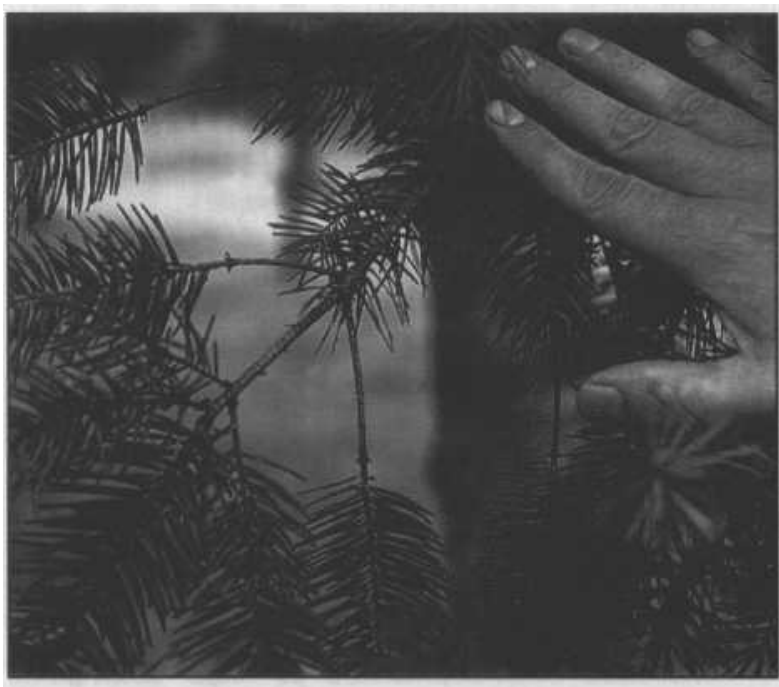

Trees with Swiss needle cast often retain only one or two year's worth of needles compared to the four year's retained by healthy Douglas-fir (left). Diseased needles turn yellow and are easily shed (right).

\section{Washington-48}


Most plantations with severe symptoms are 10 to 25 years old and within 15 miles of the coast in an area prone to fog; before they were logged, these areas were dominated by hemlock, spruce, and cedar. Swiss needle cast also infects plantations farther inland on the west side, typically where large plantings of Douglas-fir occupy valleys surrounded by hills or mountains, where poor air drainage contributes to the buildup of the fungus. These inland plantations usually recover from heavy infection after 2 to 5 years, so changing them to species other than Douglas-fir is unnecessary. The disease can be controlled with fungicides, but treatment in forest plantations is uncommon and not usually advised.

\section{Hemlock}

Two dwarf mistletoes infect hemlock trees-Western hemlock dwarf mistletoe is the most widespread dwarf mistletoe in western Washington. Taxonomically, this parasitic plant is separated into two subspecies that look almost identical but are specific to the two species of hemlock found in western Washington: western hemlock and mountain hemlock. Each subspecies also infects a variety of true firs, spruces, and pines to a much lesser extent than hemlock. Western hemlock dwarf mistletoe is a serious parasite along the Pacific coast from California north to Glacier Bay, Alaska. As with all dwarf mistletoes, infected trees show increased mortality, reduced growth, lower fiber quality, and an increased susceptibility to other disturbance agents. Heavily infected trees show growth reduction in both volume $(40 \%)$ and height $(84 \%)$ compared to uninfected or lightly infected trees.

Mountain hemlock dwarf mistletoe is common on mountain hemlock and true firs in northern California and the Oregon Cascades but, until recently, was thought to be restricted to small populations in two areas in Washington-north of Mount Baker and in the southern Olympic Mountains. Surveys conducted in 1995 in the Washington Cascades discovered at least three new, widely separated populations of this parasite.

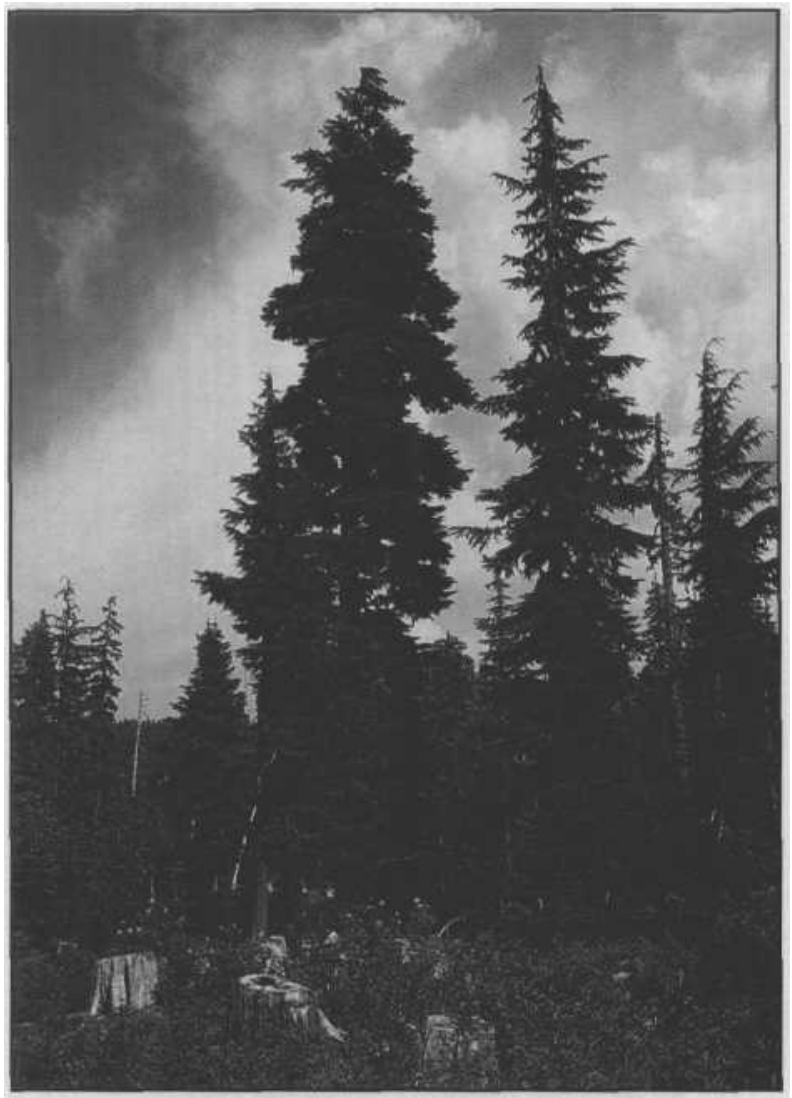

Hemlock infected by dwarf mistletoe is deformed, grows less, and is often killed. The large tree on the left is heavily infected with many mistletoe "brooms" (excessive branch growth caused by the infection).

Western hemlock looper is a pest of old growth - The primary host for hemlock looper is western hemlock, although it will feed on other conifer species and understory shrubs found in association with western hemlock. Heavy, repeated defoliation during an outbreak can result in tree mortality.

Western hemlock looper is generally very successful in extensive, old-growth, western hemlock forests. Early records of western hemlock looper outbreaks show vast amounts of timber killed in northwest Oregon and southwest Washington. Outbreaks generally last about 3 years and are usually brought under control by the natural action of parasites, predators, and disease. Out- 


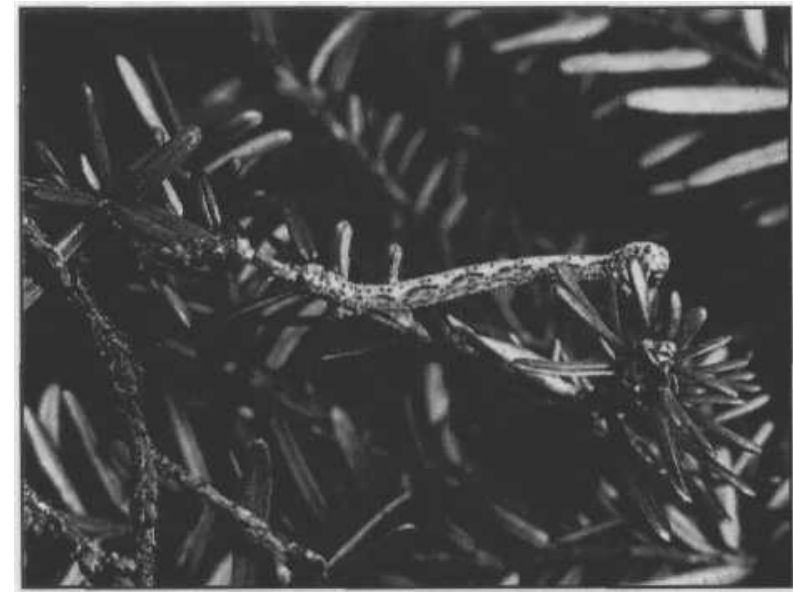

Outbreaks of hemlock looper, an old-growth insect, may increase on federal lands as harvesting decreases and more stands reach and exceed 100 years of age.

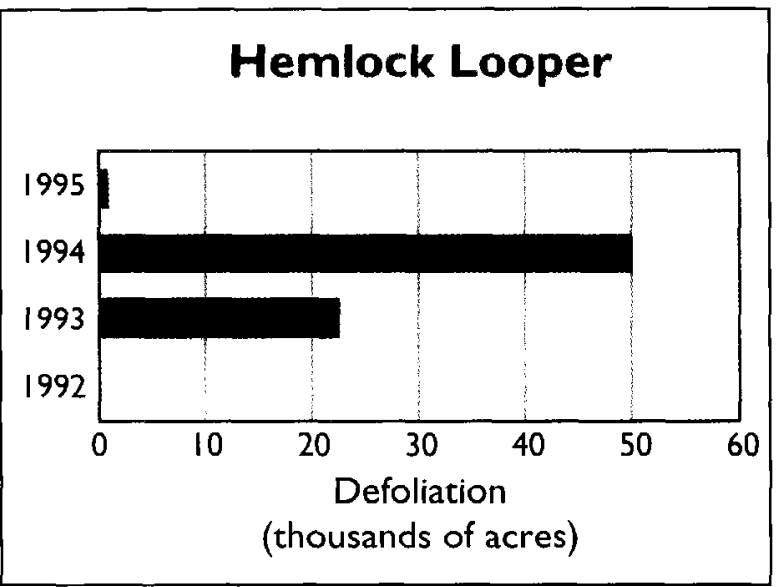

An outbreak of hemlock looper was detected in 1993 and 1994 in western Washington. The population Collapsed in 1995. Source: Cooperative Aerial Survey, Washington Department of Natural Resources and USDA Forest Service.

breaks can also occur in vigorous 80 - to $100-$ year-old stands.

Today, the majority of stands that will support large hemlock looper populations are in parks and reserves, mostly on federal lands in northwest Washington. Those lands with 80to 100-year-old, vigorous western hemlock stands or multistory older, predominantly ma- ture timber are susceptible to hemlock looper outbreaks.

The most recent defoliation from western hemlock looper was found on the Mount Baker-Snoqualmie National Forest. It was first noticed during the 1992 aerial survey. The outbreak peaked in 1993 with more than 49,000 acres defoliated. Populations collapsed sometime between 1994 and 1995. In 1995, extensive ground evaluations by forest health specialists did not detect any live insects.

\section{True Fir}

True fir stands continue to be changed by an introduced insect-The balsam woolly adelgid, an insect native to Europe, was first noticed in the Pacific Northwest in the 1930s on true firs in the Willamette Valley in Oregon. It gradually spread to true firs in the mountains. It slowly kills trees by infesting the twigs and branches, or kills them quickly by infesting the bole. It causes gouting (swelling) of branches and sometimes of the trunk. Damage and mortality are mostly confined to true fir stands on federal lands, but it could spread to all susceptible true fir stands. The Gifford Pinchot, Mount Baker-Snoqualmie, and Olympic National Forests report the highest mortality associated with balsam woolly adelgid.

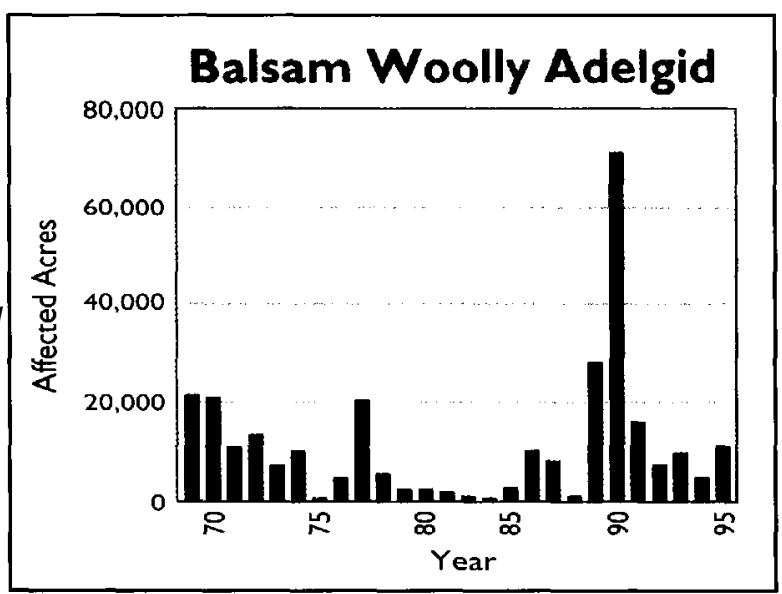

The number of acres with balsam woolly adelgid damage in western Washington since 1969. Source:

Cooperative Aerial Survey, Washington Department of Natural Resources and USDA Forest Service. 


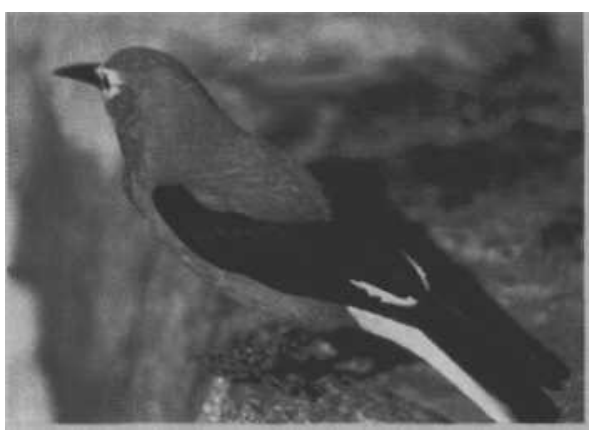

Clark's nutcracker.

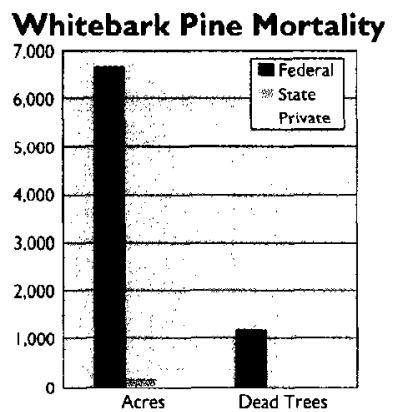

Whitebark pine mortality in Washington. Source: Cooperative Aerial Survey, Washington Department of Natural Resources and USDA Forest Service.
Wildlife habitat is affected by the decline of whitebark pine. White pine blister rust, fire exclusion, and mountain pine beetle continue to cause decline in whitebark pine. This tree is a prominent upper-subalpine species that is important as a source of food and habitat for many animals, including the grizzly bear, and is a keystone species in high-altitude ecosystems. Studies in 1991 and 1992 in northwestern Montana showed the number of mature whitebark pines rapidly decreasing. Some whitebark pine stands in Glacier National Park have mortality rates of up to $90 \%$. Recently, interest in the effects of blister rust on the survival of whitebark pine in the northwestern portion of its range, which includes Washington, has increased. A preliminary survey in Mount Rainier National Park completed in 1994 showed blister rust present in all whitebark stands inventoried. Twenty-seven percent of the plots within these stands had no infected trees, supporting existing evidence that whitebark pine exhibits a slight natural resistance to the rust. Because the seeds of the tree are spread by a bird, Clark's nutcracker, that caches them in the ground, the most effective management action to preserve this species would be to use fire to make clearings in the thick, true fir stands so the birds have a cleared place to hide the few seeds produced by naturally resistant trees.

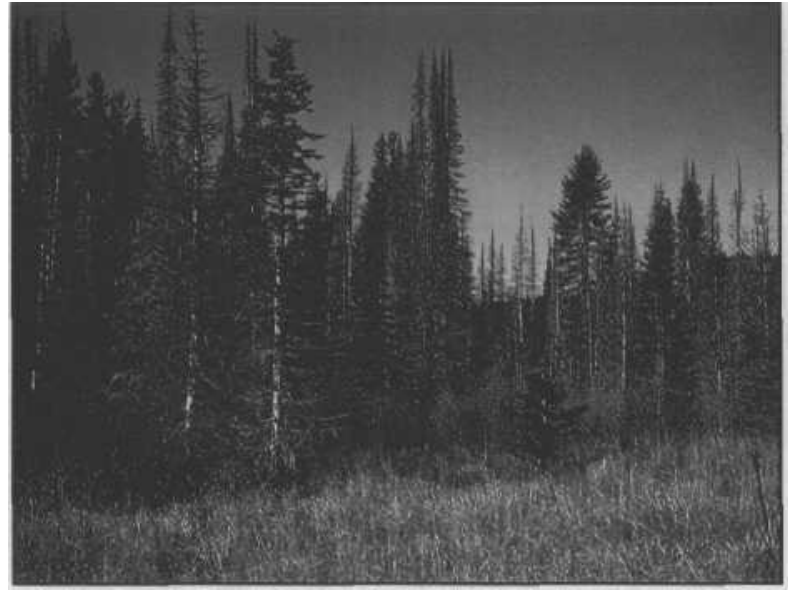

Balsam woolly adelgid has caused dieback and death of hundreds of true fir since its introduction from Europe in the 1930s.

Photo courtesy of Russe/Mitchell.

\section{Hardwoods}

A decade of summer drought damages hardwoods - Nearly 10 years of continual summer drought between 1987 and 1995 has been hard on hardwoods in western Washington. The most commonly affected species are red alder and bigleaf maple, although conifers are affected as well. Damage has been widespread, found in the Puget Sound area, the Cascade foothills, and the San Juan and Puget Sound Islands. Moisture stress and resulting damage or death occurs between June and September. Symptoms range from scattered, fading or red branches to whole tree mortality. Often whole stands are affected, some losing up to $50 \%$ of the trees. This type of damage is common on soils that dry rapidly in the 


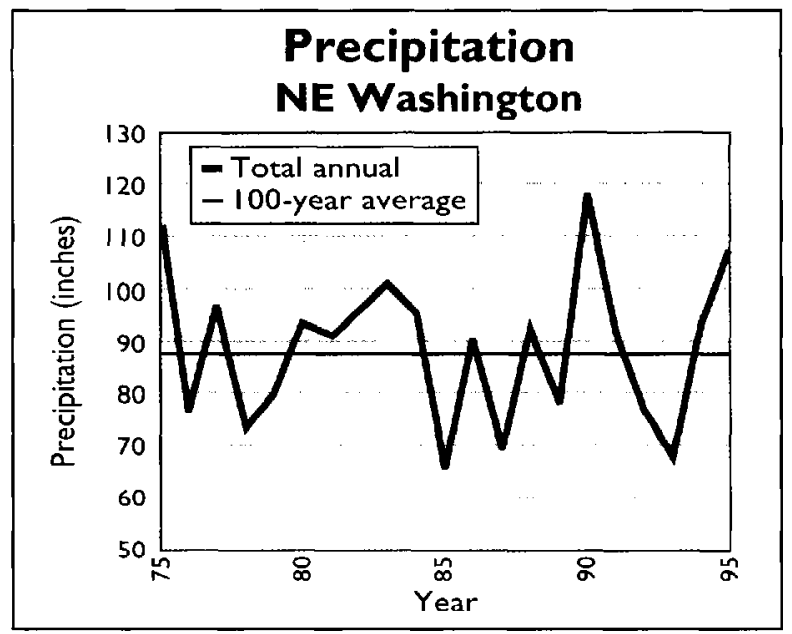

Annual precipitation in the western Cascades was lower than average most of the years between 1985 and 1993. Source: Washington Department of Natural Resources.

summer, such as shallow, hardpan or deep, gravelly soils.

Diseases or outbreaks of insects, such as forest tent caterpillar on red alder in 1987, often are associated with drought-stressed trees and accelerate tree death. By themselves, many of these insects or diseases rarely cause mortality.

Pacific dogwood is affected by fungus-Since the early 1970s, the native dogwood in western Washington has been infected by anthracnose, an introduced fungus disease of foliage and stems, that is often fatal after a few years of infection. Many west-side dogwoods have succumbed to the disease over the last 20 years. Some stands that had five dogwoods per acre 20 years ago may have none today. In other areas, the disease is not as common. Dogwood under story in the eastern parts of the Columbia Gorge is generally healthy.
Pacific madrone is injured by winter freezes-Winter freezes periodically damage tens of thousands of Pacific madrones throughout the Puget Sound region. Injury ranges from leaf browning to branch dieback and tree mortality. Trees with only leaf browning usually recover. Madrone trees with winter freeze damage have been noted in 1972, 1985, and 1990. In the spring of 1996 , madrones suffered nearly complete browning of the leaves. Sometimes the leaves at the tops of the trees were relatively undamaged. Often, affected trees were found adjacent to completely uninjured trees. A weak parasitic fungus is suspected of colonizing the leaves after they were stressed by cold weather in January 1996. Two leaf-mining insects were also found in the injured leaves and probably contributed to about one-third of the foliage damage. Emergence of normal-appearing 1996 leaves nearly hid the dead leaves. Whether the fungus can persist and spread to the new leaves is unknown.

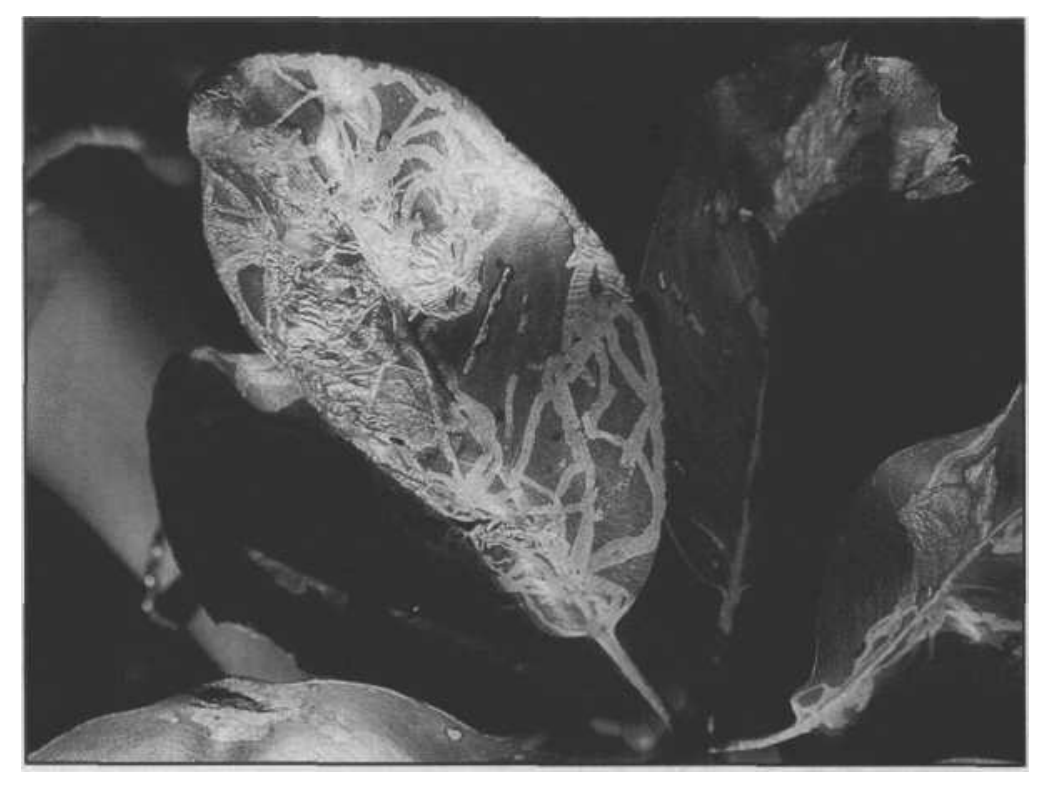

Leaf miners are one of several insects that attack Pacific madrone. 


\section{EASTERN CASCADES (M242C) AND OKANOGAN HIGHLANDS (M333A)}

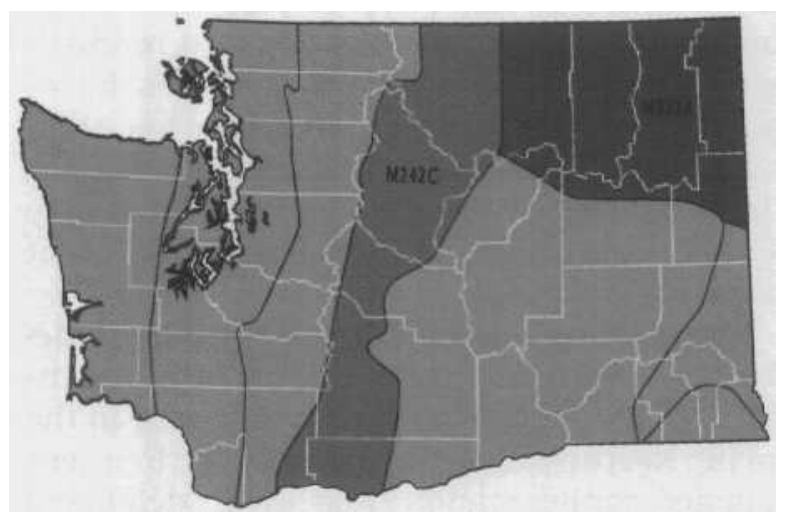

\section{Ecology}

Eastern Cascades - The eastern Cascades region in Washington consists of the eastern slopes of the Cascade Range, which extends north into Canada and south into Oregon. Elevation ranges from near sea level at the Columbia River to more than 10,000 feet in the high mountain peaks. Precipitation patterns are the key force for determining vegetation in

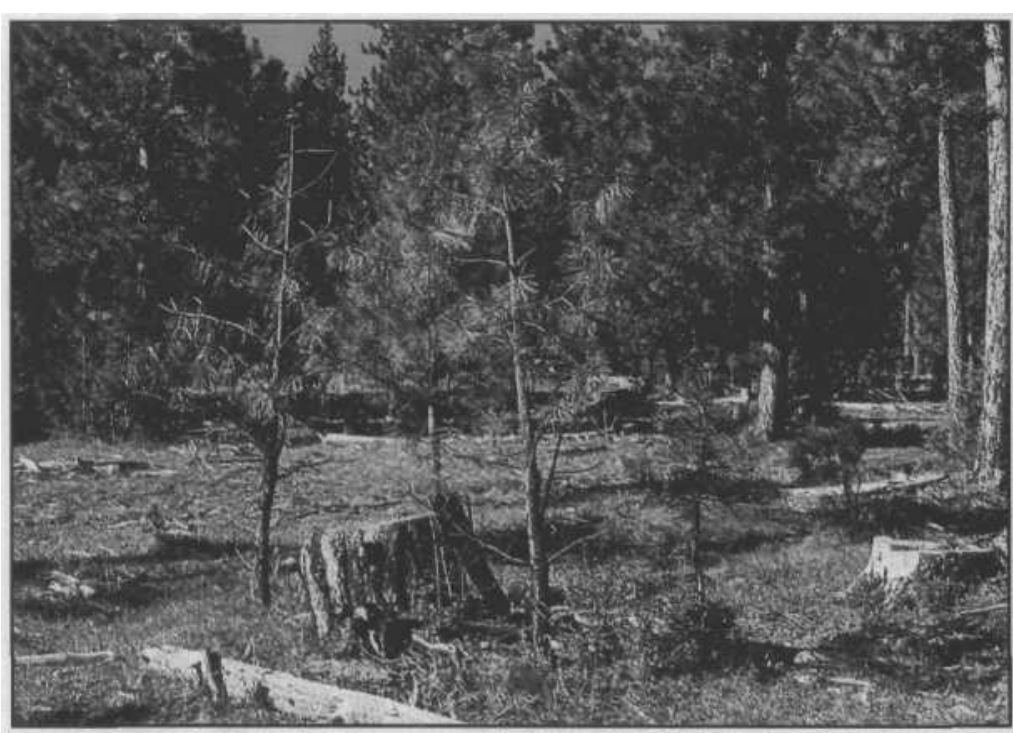

Annosus root disease fungus produces spores that infect stumps; the disease spreads from infected stumps to live trees by rootto-root contact. the eastern Cascades. At high elevations that receive more rain and snow, true fir, mountain hemlock, and Douglas-fir forests predominate. At lower elevations, where moisture is sparse, ponderosa and lodgepole pines grow. Lodgepole pine is common on dry sites with poor soils. Local areas of whitebark pine, white pine, Engelmann spruce, and aspen are also found in the eastern Cascades. Fire periodicity is extremely variable. In the pine forests at lower elevations, fire occurred at 10- to 15-year intervals before fire suppression. Fire was less frequent at higher elevations.

Okanogan Highlands-The Okanogan highlands are characterized by moderate slopes and broad, rounded summits. Several north-south rivers flow in this region, including the Columbia, Okanogan, Colville, and Pend Oreille Rivers. Vegetation patterns in the Okanogan highlands are strongly influenced by the east-west precipitation gradient. Precipitation averages 30 to 60 inches per year, mostly as snow. Although ponderosa pine can be found growing in pure stands, it is more often found growing with other species in mixed stands, including Douglas-fir, grand fir, western larch, and lodgepole pine as major associates. At higher elevations, Douglas-fir and true fir forests predominate. Historical fire regimes ranged from frequent, lowintensity fires to infrequent, high-intensity fires.

\section{Mixed Conifers}

Root diseases continue to increase in eastern Washington-Laminated root rot is widespread throughout eastern Washington forests. The disease is increasingly common in the mixed conifer stands of northeastern Washington, where Douglas-fir and grand fir are much more abundant in stands once dominated by ponderosa pine and western larch. Pine and larch tend to be more tolerant of the disease. 
Annosus root disease has also increased in distribution and severity as a result of management practices. Selective logging creates abundant stumps of ponderosa pine, grand fir, and Subalpine fir that can be infected by airborne spores. This increase in infection sites is compounded by high tree densities that increase the probability of tree-to-tree spread through root contact. Annosus root disease is particularly common in mixed stands of true fir and Douglas-fir of the southern Cascades near Yakima and Goldendale.

Eastern Washington has areas with large amounts of schweinitzii root and butt rot in late seral and climax stands. The primary host is Douglas-fir, but western larch, spruce, and true fir are also infected. Infected trees rarely

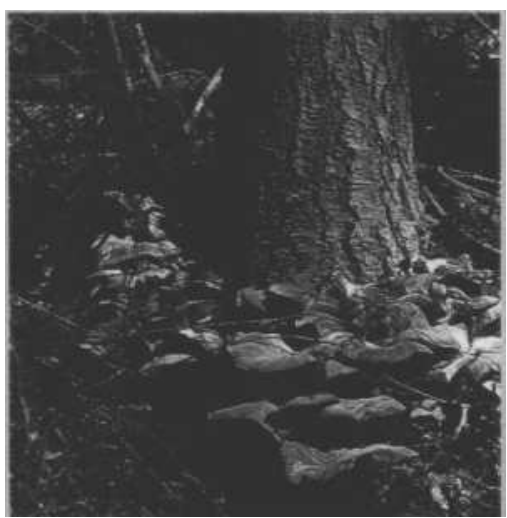

The fungus that causes armillaria root disease often produces edible mushrooms at the base of infected trees.

Armillaria root disease. Incidence of armillaria root disease is also on the rise in the expanding Douglas-fir/grand fir timber type; mortality has increased because of stress from overstocking. The disease is severe on Douglas-fir and grand fir in northeastern Washington. Armillaria is sometimes extremelyaggressive and attacks trees that do not appear to be under stress, such as Ponderosa pine in pure pine stands southeast of Mount Adams. show outward signs of infection. The best way to detect the root rot is to find the large, rusty brown and often velvety, mushroom-like fruiting bodies on the ground near infected trees. Infected wood is stained red in Douglas-fir, and the advanced decay breaks down in reddishbrown cubes. As in other root diseases, infection usually starts in root tips rather than through old fire scars or wounds, as was once thought. Trees with extensive butt decay may attract bark beetles and even armillaria root disease.

Western spruce budworm damage is declining-Western spruce budworm is a common defoliator of Douglas-fir and true fir in the Pacific Northwest, and outbreaks are frequent in mixed-conifer stands. Repeatedly defoliated trees show substantial radial-growth reduction, and are often predisposed to attack by bark beetles. Effective fire prevention and suppression during this century have eliminated many major fires and nearly all surface fires. As a result, forests that have had no other disturbances, such as timber harvesting, have moved steadily toward climax and, consequently, an abundant and expanding source of the insect's favorite food-shade-tolerant, late-successional tree species.

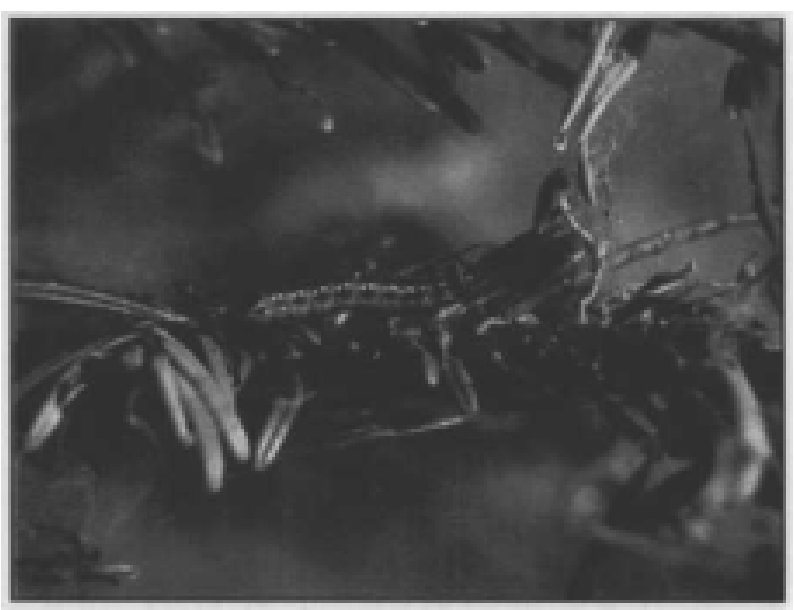

Western spruce budworm larvae prefer new foliage, but also feed on older foliage when new foliage is in short supply. 


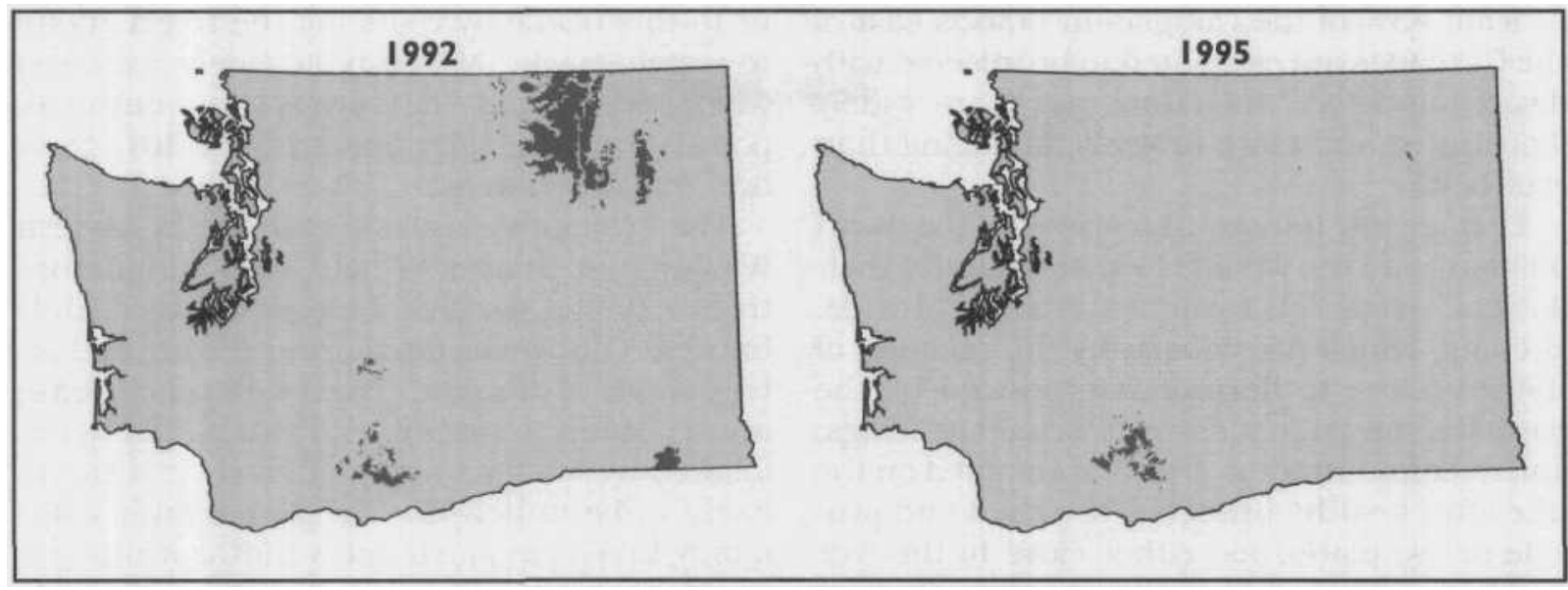

The number of acres defoliated by western spruce budworm has declined sharply since 1992 (left) compared to 1995 (right), especially in the Okanogan area (northeast corner of the state). Source:

Cooperative Aerial Survey, Washington Department of Natural Resources and USDA Forest Service.

Budworm populations have declined significantly since 1992 , when over 1.3 million acres showed some defoliation in eastern Washington. The decline is attributed to a natural collapse of the insect population and increased precipitation. Areas of budworm defoliation increased slightly in 1995 compared with 1994.

Dwarf mistletoe abundance is tied to host distribution, fire, and harvest-Dwarf mistletoes are found on all of the conifers in the mixed conifer forests of eastern Washington. The distribution and frequency of dwarf mistletoe species closely follows the distribution and frequency of their hosts. Before 1900, western larch dwarf mistletoe was the most widespread mistletoe in late seral stands. Western larch is less prevalent today but, because of selective harvest which creates conditions favorable to spreading mistletoe, the remaining larch have a high incidence of dwarf mistletoe.

In stands east of the Cascades, ponderosa and lodgepole pine dwarf mistletoes were historically more localized and less damaging than now because of the frequency and sanitizing effects of natural ground fires. Frequent underburning minimized the accumulation of fuels and the likelihood of stand-replacing fires. Many stands had some dwarf mistletoe infection, but the severity was continually reduced by the frequent fires. In lodgepole pine, standreplacing fires at intervals of 90 to 200 years eliminated mistletoe, along with the trees. In Ponderosa pine stands, fire suppression has led to more widespread dwarf mistletoe.

In ponderosa pine stands that have converted to true fir and Douglas-fir because of fire suppression, pine dwarf mistletoes have decreased and fir mistletoes have increased.

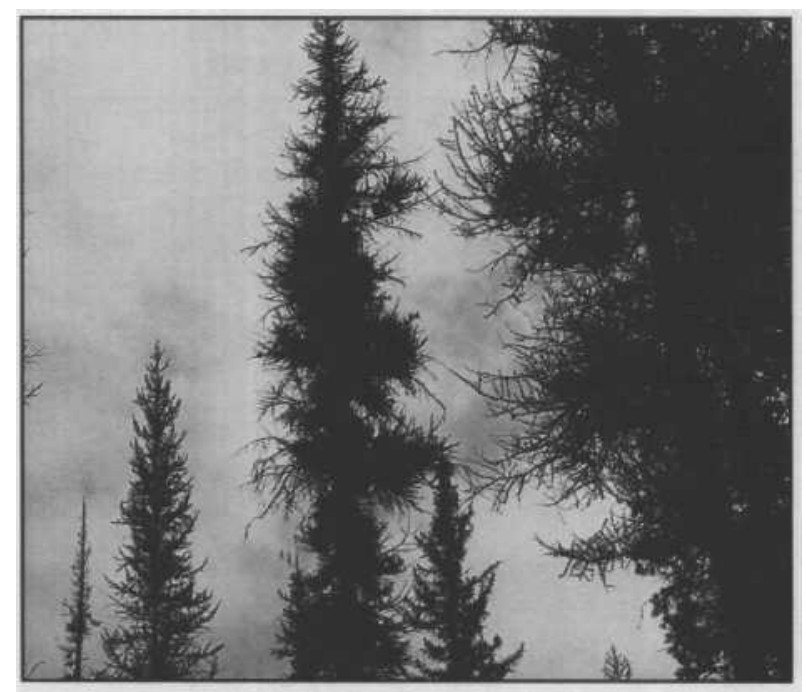

Western larch dwarf mistletoe can be extremely damaging; mistletoe brooms on larch are brittle and break off, leaving infected trees with few branches. 
At least $43 \%$ of the Douglas-fir stands east of the Cascades are estimated to be infected with dwarf mistletoe. Infections are more widely distributed and more severely damaging than ever before.

Ecologically important features of the dwarf mistletoe are the wildlife food and habitat their flowers, seeds, and witches brooms provide. Brooms, which are caused by the reaction of the host tree to hormones produced by the parasite, are large masses of branches, twigs, and needles. Brooms are often retained on the tree after healthy branches are shed and provide dense platforms, either close to the tree trunk or scattered about the crown. Brooms are used for nesting, roosting, and hiding cover by small mammals and birds, especially owls, hawks, and grouse.

Drought, defoliation, and disease contribute to susceptibility to bark beetlesIn eastern Washington, the Douglas-fir beetle normally breeds in felled, injured, or diseased trees. Drought, root diseases, and repeated years of defoliation by western spruce budworm increase the susceptibility of Douglas- fir to this beetle by reducing the tree's ability to resist attack. Mortality is widely scattered when beetle populations are low, but outbreak populations can kill apparently healthy trees over extensive areas.

The fir engraver infests true firs in eastern Washington. It attacks pole-sized and mature trees, causing significant mortality during outbreaks. Outbreaks often occur during and after periods of drought. Trees with root disease are especially susceptible to attack. Trees defoliated by western spruce budworm also are likely to be attacked. The fir engraver commonly breeds in slash and windthrown trees.

\section{Pines}

Mountain pine beetle causes mortality of many pines-Mountain pine beetle occurs throughout the range of pine in the Pacific Northwest. Infestations have resulted in extensive mortality over large areas. In 1995, mountain pine beetle in eastern Washington was reported to have killed 406,000 trees of four different species of pine on 201,000 acres.
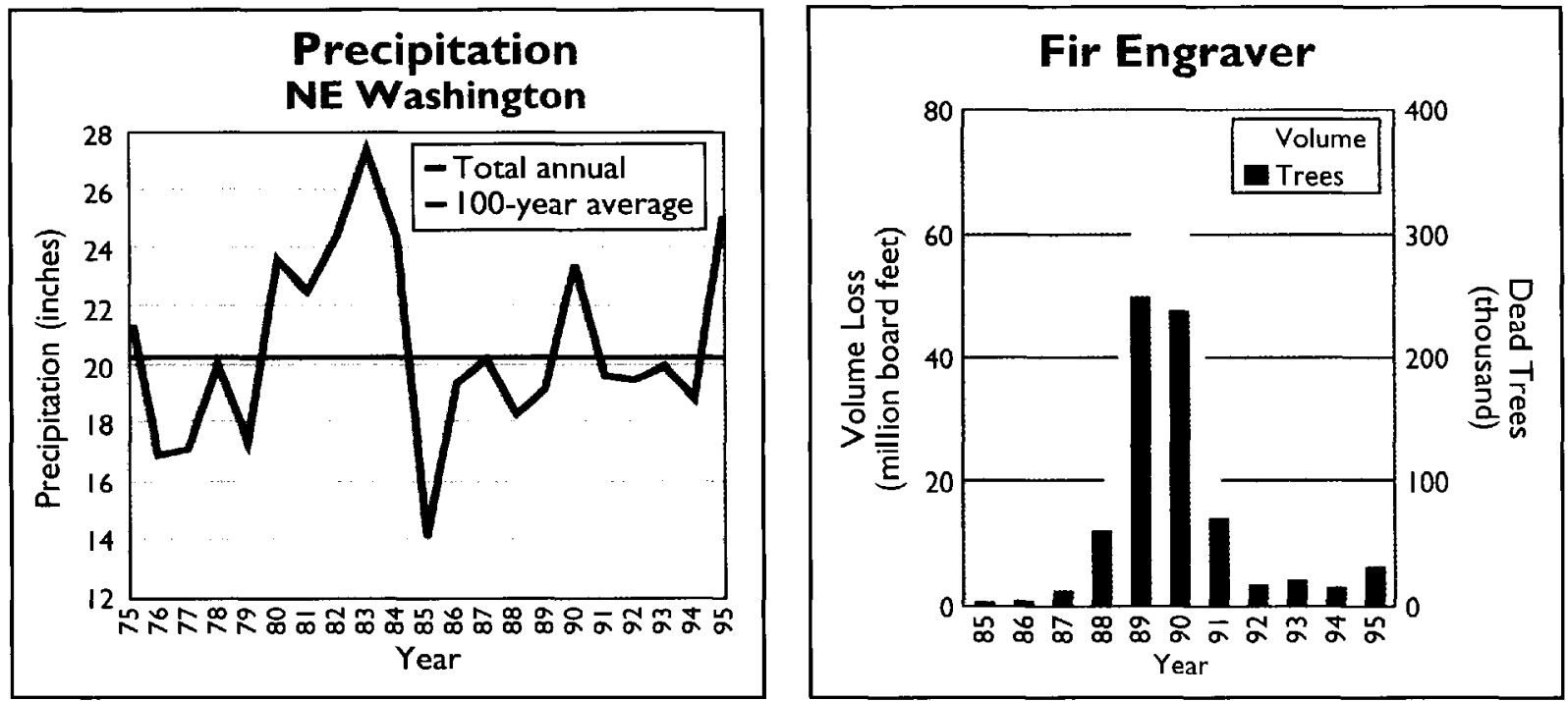

Precipitation in northeastern Washington was lower than normal most years between 1985 and 1994 (left). Fir engraver activity was also highest during this period (right). Source: Washington Department of Natural Resources (precipitation data); Cooperative Aerial Survey, Washington Department of Natural Resources and USDA Forest Service (insect data). 
Table 3-1-Effects of mountain pine beetle on eastern Washington pines

\begin{tabular}{|c|c|c|c|c|}
\hline Effects & $\begin{array}{l}\text { Lodgepole } \\
\text { pine }\end{array}$ & $\begin{array}{l}\text { Ponderosa } \\
\text { pine }\end{array}$ & $\begin{array}{l}\text { Western white } \\
\text { pine }\end{array}$ & $\begin{array}{l}\text { Whitebark } \\
\text { pine }\end{array}$ \\
\hline $\begin{array}{l}\text { Greatest } \\
\text { impact }\end{array}$ & $\begin{array}{l}\text { High-density } \\
\text { mature trees }\end{array}$ & $\begin{array}{l}\text { Immature } \\
\text { pole-sized }\end{array}$ & $\begin{array}{l}\text { Big, old }(>250 \\
\text { yr) trees }\end{array}$ & $\begin{array}{l}\text { Big, old } \\
\text { trees }\end{array}$ \\
\hline How it kills & $\begin{array}{l}\text { Many trees over } \\
\text { extensive area }\end{array}$ & $\begin{array}{l}\text { Groups of } \\
\text { several } 100\end{array}$ & Individuals & Individuals \\
\hline $\begin{array}{l}\text { Trees } \\
\text { killed in } \\
1995 \text { (no.) }\end{array}$ & 342,000 & 52,000 & 11,000 & 1,000 \\
\hline $\begin{array}{l}\text { Acres } \\
\text { affected in } \\
1995 \text { (no.) }\end{array}$ & 122,000 & 58,000 & 14,000 & 7,000 \\
\hline
\end{tabular}

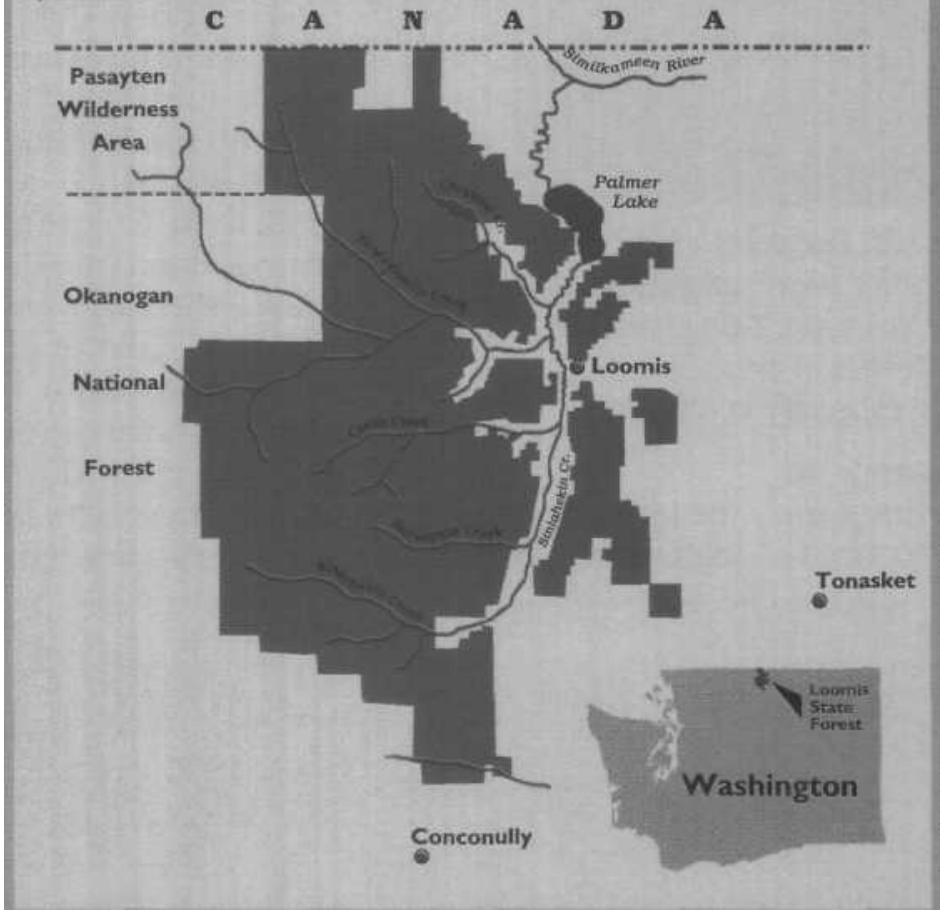

The Loomis State Forest is the largest contiguous block (144,000 acres) of land managed by the Washington State Department of Natural Resources.
Long-term management for the Loomis State Forest The Loomis State Forest, west of Tonasket is the largest block of state-owned forest land in Washington. In addition to its designation as a common school trust land, managed to produce income for construction of public schools, the Loomis State Forest provides valuable habitat for the threatened North American lynx, roadless recreation sites adjacent to the Pasayteri Wilderness Area, water resources for downstream communities, and grazing land. Controversy has surrounded potential management of the forest, especially when such uses conflict.

In the late 1980s, a mountain pine beetle outbreak began to visibly affect portions of the Loomis State Forest containing old, large-diameter lodgepole pine. By 1993, more than 20,000 acres had been affected,

with an average of $40 \%$ of the timber volume killed on those sites. About 28,000 acres containing large-diameter lodgepole pine continue to be at risk of attack.

To address numerous and conflicting concerns about managing this block, an 80-year plan has been prepared and approved. The Department of Natural Resources plans to accelerate harvest in the beetle-susceptible lodgepole pine stands and create a better mosaic of age structure. This strategy will improve lynx habitat and increase stand resistance to future attack by the beetles, while not precluding other forest uses. 
Western pine beetle kills big, old, ponderosa pineWestern pine beetle sometimes attacks ponderosa pine in the Pacific Northwest. Normally, this beetle breeds in large, old trees; in windfalls; in trees infected by root disease; or in trees weakened by drought, overstocking, or fires. Losses are significant because large, old pines are under-represented across the forested landscape in many areas in eastern Washington. Western pine beetle also attacks and kills trees of all ages that have bark sufficiently thick to protect the insect during development.

\section{Aspen \\ Satin moth and moisture stress are killing many aspen stands - Defoliation by}

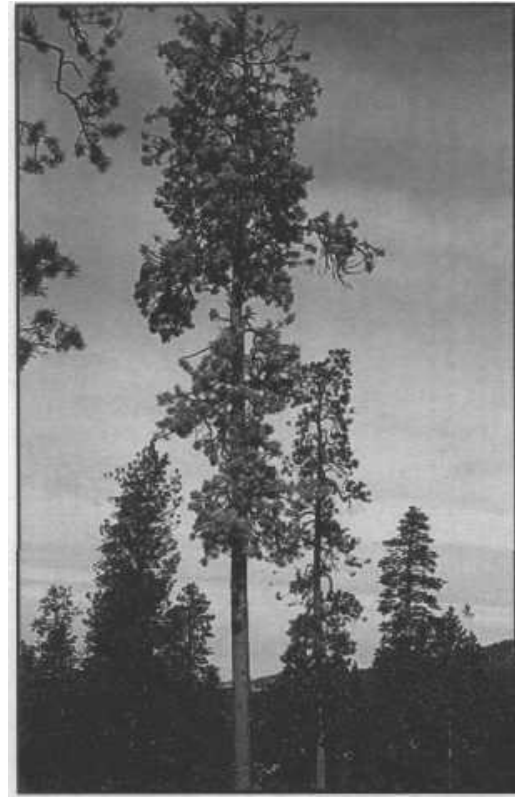

Large, old, ponderosa pine, important for their ecological and scenic value, are being killed by bark beetles in overstocked stands, especially in dry years. satin moth has killed many aspen stands in north-central and northeastern Washington. Affected stands tend to be older than unaf- fected ones and apparently unable to withstand insect defoliation. Moisture stress was likely a factor in the mortality. The defoliated stands were isolated from other hardwood stands and do not have many predators or parasites to keep the satin moth populations in check.

Satin moth, introduced from Europe, was first found in North America in 1920, both in New England and in southwestern British Columbia. In the West, it has spread southward to northern California, and into the interior of Oregon, Washington, and southern British Columbia. After its introduction into British Columbia, the satin moth was considered a pest of economic importance. With the introduction of European parasites of the moth during the late 1920s and early 1930s, successful biological control has generally been achieved.

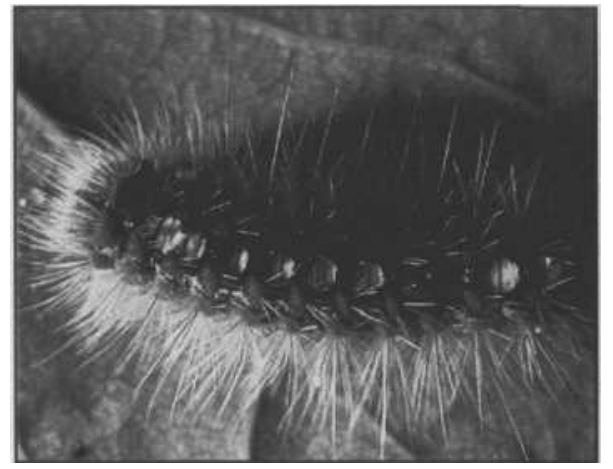

Satin moth larvae feed on aspen leaves (above). Entire groves of aspen can be defoliated by the satin moth (right). Older, moisture-stressed trees are the most vulnerable.

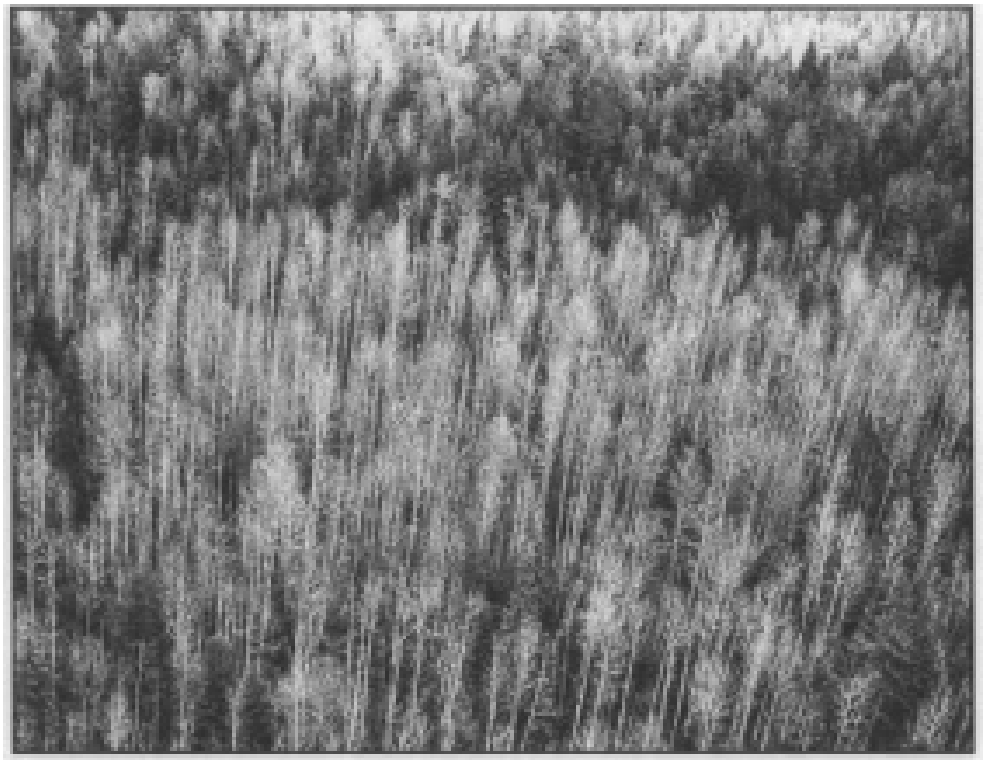




\section{CHAPTER 4. DISTURBANCE AND URBAN FOREST HEALTH}

\section{Introduction}

An urban or community forest is the sum of planted landscape trees and remnants of the native forest intentionally or inadvertently left behind during the building of the city. Urban forestry is the discipline concerned with managing these forests.

Urban forest health is less than idealThe health of Oregon's and Washington's community forests is poor in many towns and cities. Erratic maintenance, old age, lack of species diversity, insects and diseases, development pressures, and weather combine to create a myriad of problems for urban trees. Although Oregon and Washington have been at the forefront in traditional forest management, their urban forestry practices have lagged significantly behind other regions of the United States.

Most community forests have aging or overmature trees. Many of these trees were planted and left without adequate care, and others simply were the wrong trees in the wrong places. In Oregon and Washington cities, tree replacement consistently lags behind tree removal, but recent surveys of Northwest communities show that tree planting is increasing.

East of the Cascades, environmental changes, tree age, and pests are taking a great toll on community trees. Historically, the region was planted with a few hardwood species, such as black locust, Siberian elm, poplars, and various conifers. Although tenacious, these species have characteristics some people consider undesirable, such as weak wood, messy fruit, and prolific sprouting, which can result in high maintenance costs. Replacing them with a diverse selection of more appropriate species or cultivars will reduce maintenance costs and improve the health of the urban forest.

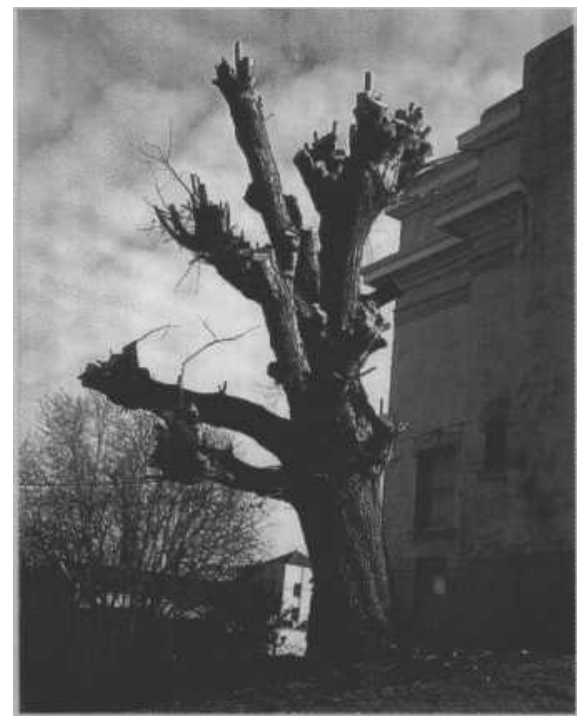

Tree topping stresses urban trees. Many landscape trees have suffered from "topping," the practice of indiscriminantly removing the large branches in the crown of a tree. Because trees need leaves to produce energy, removing the canopy causes trees to slowly starve. With this stress, trees become more susceptible to insect and disease damage. Wounds created by topping provide places of entry for decay organisms. The resulting decay often goes unseen and undetected until the tree fails. Dead wood and poor branch structure also contribute total and costly tree failures. 
Community forests have not escaped the insect and disease outbreaks plaguing the rural forests. Many conifers like Douglas-fir and Ponderosa pine are found in both rural and urban areas, and so too are the insects and diseases that afflict them. Management of the recent pandora moth outbreak in central Oregon, for example, not only concerns the Deschutes National Forest, but also the city of Bend - though on a different scale. Descriptions of the more important insects and diseases of urban forests follow.

\section{Disturbance Agents In Urban Settings \\ Fire and windthrow are a potential threat to homes in forested areas-Homes, increasingly being built at the urban-forest}
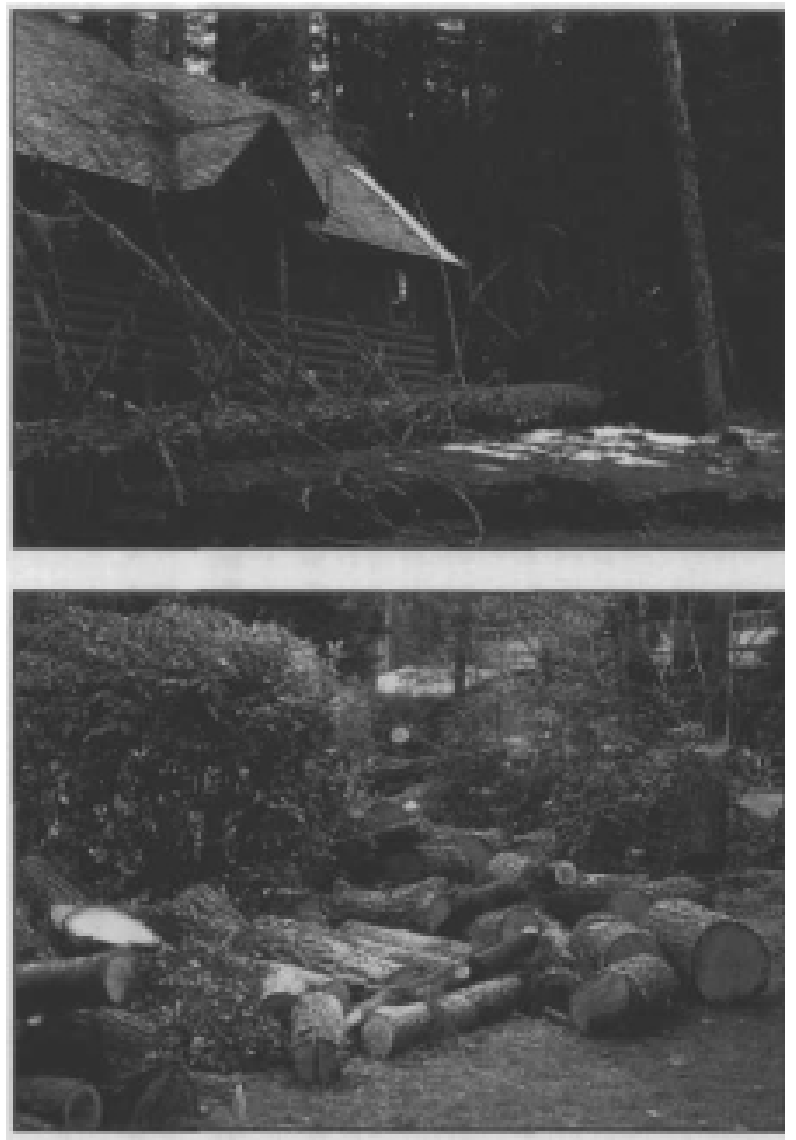

Root rot disease often creates hazards when houses are built in forests (top). Removal of hazardous trees can be costly and unsightly (bottom). interface, are at risk of being destroyed or damaged by wildfires or falling trees. Trees with internal decay or root disease (such as laminated root rot) are particularly susceptible to windthrow or breakage during wind or ice storms. Thinning or removal of groups of trees to accommodate house construction may also lead to windthrow during storms; the remaining trees are often unstable because of heightto-diameter ratio and altered wind patterns. Home owners need to know that managing the vegetation around their homes is essential to protect their lives and prevent property damage. Where vegetation is not properly managed, the costs of fire protection and storm clean-up increases for neighbors, the community, and public agencies.

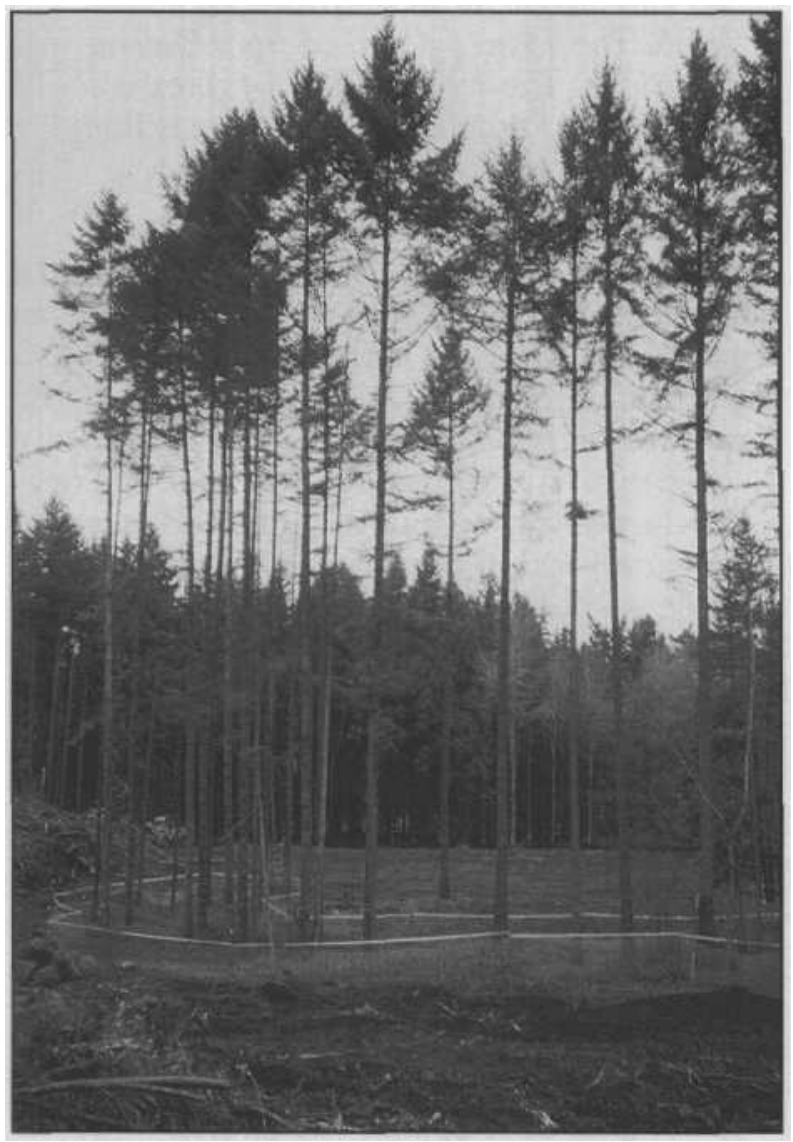

Removing or thinning trees during home construction can cause remaining trees to be unstable and prone to windthrow. 


\section{Dutch Elm Disease}

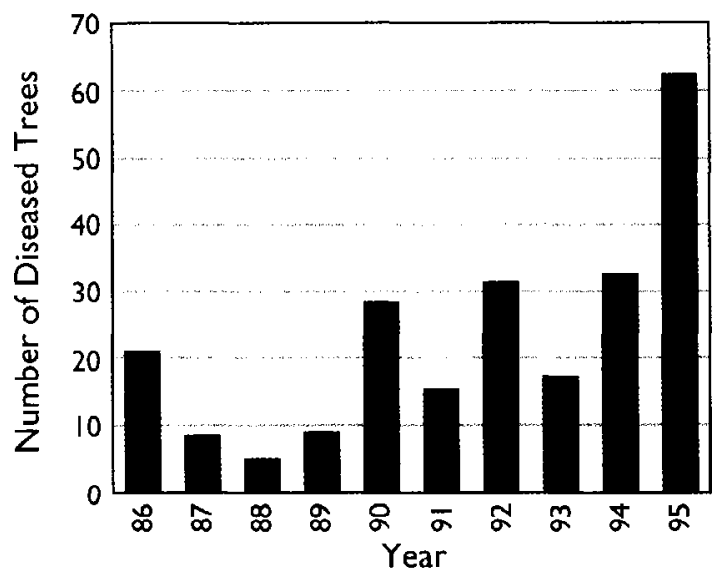

Dutch elm disease in western Oregon, 1986 to 1995. The 1986 figures are from Eugene and Portland. The 1987 to 1995 figures are removals from Portland, plus a few trees from private home owners outside of Portland.

Source: Oregon Department of Agriculture.

Dutch elm disease is increasing in Oregon and Washington-American elm is an important component of the mature urban forest environment, both east and west of the Cascades in the Pacific Northwest. Dutch elm disease is an introduced disease that has devastated trees throughout the United States and is of worldwide importance. This aggressive disease is spread from tree to tree by elm bark beetles, which carry disease spores, and also when the fungus grows from roots of an infected tree to roots of adjacent healthy trees.

Dutch elm disease was first detected in Oregon in the Nyssa-Ontario area and in Washington in Walla Walla in the 1970s. Despite control efforts, the disease has since spread to other locations throughout the two states.

The key to reducing spread and losses from this disease is prompt removal and disposal of infected trees, but many cities and towns have no such programs. In Oregon, many towns remove infected trees and dispose of the chipped wood at a solid waste site. The city of Portland injects elm trees with fungicides as a protectant against the disease.
Gypsy moth-the vigil continues-The first European gypsy moths were discovered in 1974 in Washington in the city of Renton (near Seattle) and in 1979 in Oregon in Lake Oswego (near Portland). Since then, gypsy moth has been monitored annually by the Oregon and Washington Departments of Agriculture. In 1995, more than 50,000 traps were deployed in Oregon and Washington, mostly west of the Cascades, where most population centers and gypsy moth host material are located.

The 1995 gypsy moth monitoring in Oregon and Washington had the following results:

\begin{tabular}{crc}
\hline & Oregon & Washington \\
\hline Traps placed (no.) & 14,585 & 36,166 \\
Total catch areas & 10 & 40 \\
Total moths (no.) & 24 & 149 \\
European & 24 & 146 \\
Asian & 0 & 3 \\
Hybrid & 0 & 0 \\
\hline
\end{tabular}

The newest arrival is the Asian gypsy moth; it is potentially more serious than the European gypsy moth because females can fly, and they have an appetite for conifers. In the last

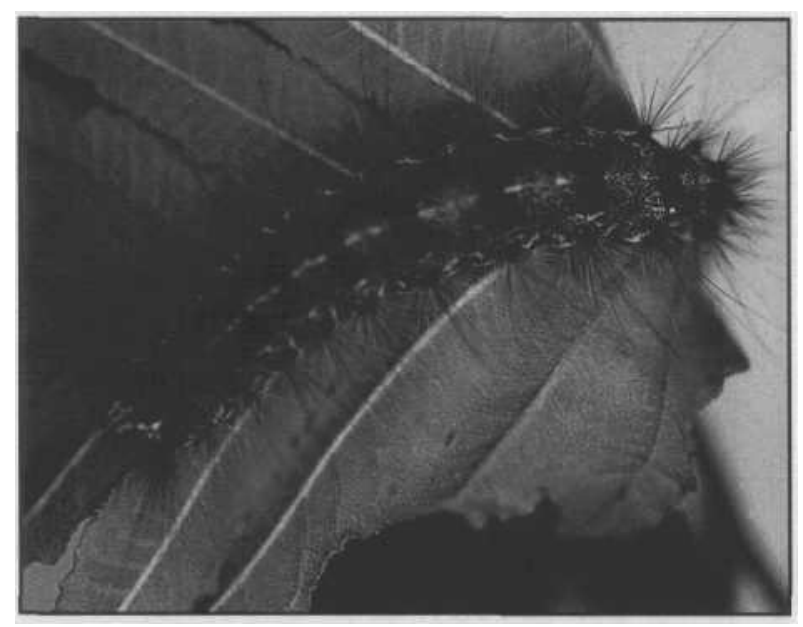

The European gypsy moth larva, pictured here, feeds mainly on hardwood foliage. Its cousin, the Asian gypsy moth, feeds on conifers and so presents a greater threat to the Pacific Northwest. 


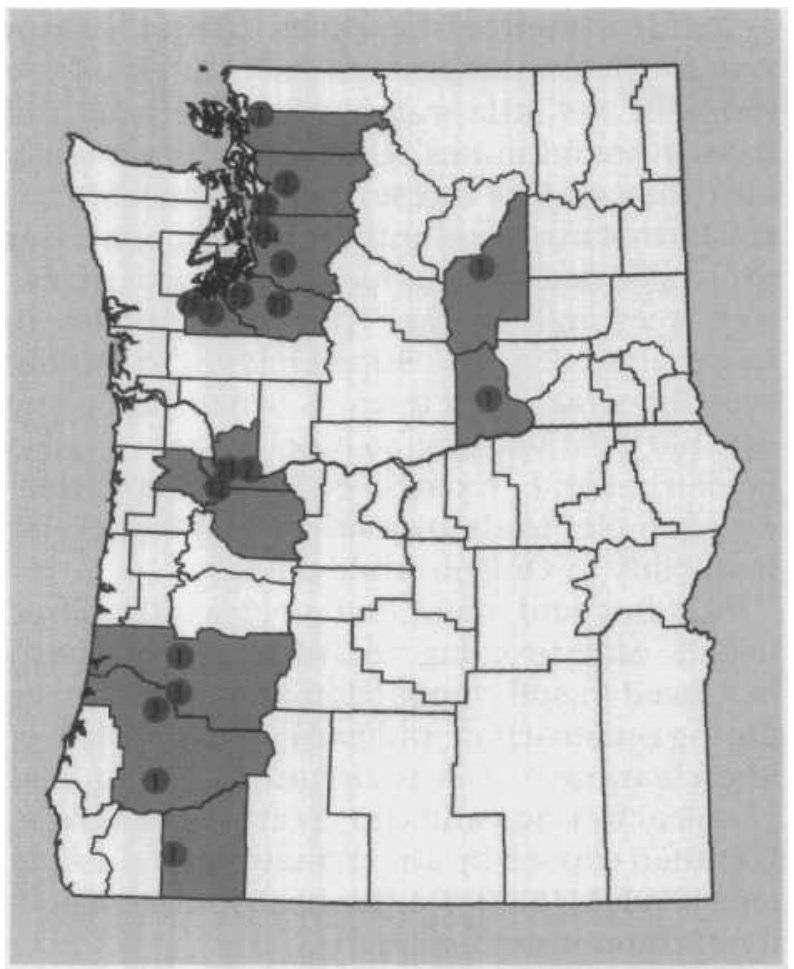

Gypsy moth was trapped in 13 counties in Oregon and Washington in 1995.

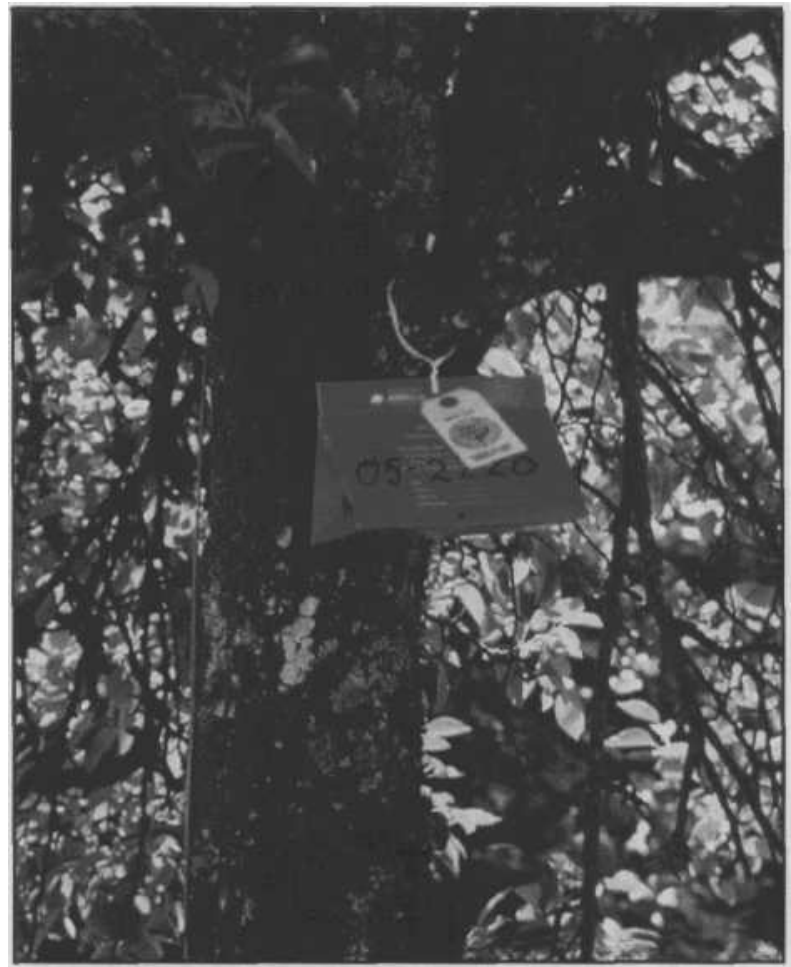

The Oregon Department of Agriculture keeps a steady watch on the gypsy moth through an extensive trapping program.

Table 4-1-Gypsy moth eradication sites in 1996

\begin{tabular}{lllll}
\hline State & County & City & Acres & Treatment \\
\hline Oregon & Multnomah & Gresham & 10 & Ground application of Bta \\
Washington & Clark & Vancouver-Union & 110 & Ground application of Bt \\
& King & Seattle-Beacon Hill & 660 & Ground application of Bt \\
& & Seattle-Beacon Hill & 360 & Aerial application of Bt \\
& Pierce & Seattle-Madrone Park & 590 & Aerial application of Bt \\
& & Tacoma-Hillsdale & 13 & Ground application of Bt \\
& Tacoma-Proctor & 19 & Ground application of Bt \\
& Thurston & Bonney Lake-Highlands & 14 & Ground application of Bt \\
& & Black Lake & 400 & Aerial application of Bt \\
& & Hunter Point & 19 & Ground application of Bt
\end{tabular}

$\mathrm{Bt}$ is a microbial insecticide, composed of the bacterium, Bacillus thuringiensis.

few years, several Asian gypsy moths have been trapped in Washington and British Columbia and one in Oregon, near ports where they have arrived on ships.

The largest outbreak in the United States was in 1984, followed by the largest control effort in 1985: 227,000 acres near Eugene, Or- egon, were treated with aerial applications of Bacillus thuringiensis (Bt), a microbial insecticide. In 1996, 10 sites in Oregon and Washington were treated with $\mathrm{Bt}$ to eradicate the moth. Treatment areas are selected on the basis of gypsy moth species (Asian or European], size of the population, and number of 
egg masses. Past eradication treatments have been successful and, fortunately, neither the European nor the Asian gypsy moth has become established in the Pacific Northwest. The gypsy moth, however, is constantly being reintroduced, so annual monitoring is necessary.

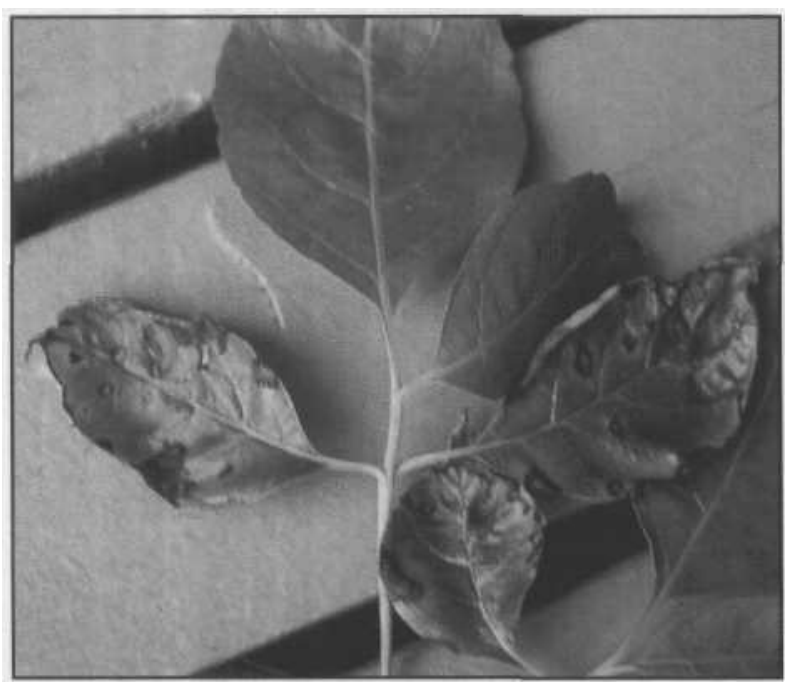

Dogwood anthracnose disease causes leaf blight, branch dieback, and tree death of ornamental and native dogwoods.

Dogwood anthracnose has become established in the Pacific Northwest-Dogwood anthracnose, a very destructive disease of flowering dogwood, first appeared in the eastern United States in the early 1970s. It was first reported on native Pacific dogwood in Washington in 1976 and in Oregon in 1983. As of 1994, the disease was present on Pacific dogwood in most western Oregon and Washington counties. Evidence suggests that this disease was introduced from abroad, but its origin remains unknown.

The disease causes leaf blight, branch dieback, and tree death on Pacific dogwood and several ornamental cultivars, and it is of particular concern in ornamental landscapes. The greatest hope for long-term disease management is to develop disease-resistant dogwoods.
Environmental stresses affect urban trees-Environmental stresses, such as too much or too little water, affect the health of trees in communities. Urban forests generally lack the complex forest floor that helps trees retain moisture and nutrients. Drought over prolonged periods can reduce the vigor of mature trees and increase their susceptibility to insects and disease. Supplemental irrigation, even for established trees, is beneficial during dry, hot weather, but too much water can also be detrimental. Excessive summer irrigation, for example, leads to root rot and structural instability in Oregon white oaks.

Building and maintaining cities affects tree health. Many existing tree health problems can be traced to soil compaction and root damage during construction, utility trenching, or power line clearance. Decay organisms enter mechanical wounds and can create hazard trees. Pollution caused by automobile and industrial emissions also affects the health and longevity of community forests.

Proper care and species selection will improve the health of urban trees-The careful observation and inventory of urban trees will detect many disease and insect problems. Given adequate funding, many can be treated. A diversity of tree species lessens the risk of catastrophic losses from weather extremes or introduced pests. Choosing the right tree for the right place, and regular pruning to remove dead wood and excessive twig growth will help keep trees healthy. As urban forests mature, the loss of older trees is inevitable. If communities maintain mature trees and plant new trees, their forests will be healthier and future generations will enjoy a thriving urban forest. 


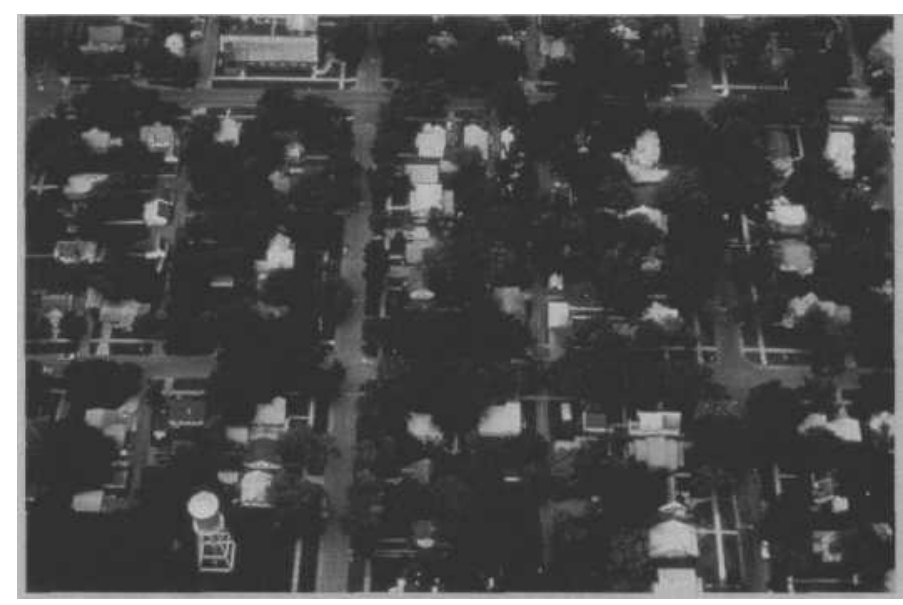

Commitment is needed for long-term urban forest health. Commitment of citizens and local governments to long-term health of their community trees will result in thriving urban forests. Interest in maintaining and improving the trees in their neighborhoods and towns is incredibly strong among residents and community organizations. Urban trees make towns and cities more livable, clean the air, screen noise, please the eye, and provide habitat for birds and other small animals; through these amenities, they make a city more attractive to potential businesses, tourists, and other sources of income. Policy makers should recognize that community trees are a worthwhile investment of time and money.

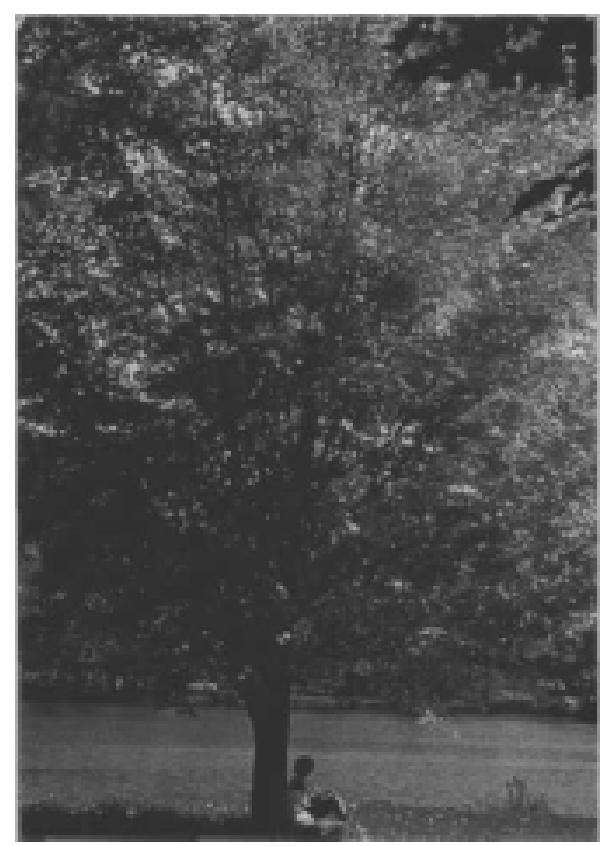




\section{CHAPTER 5. FOREST HEALTH MONITORING PILOT PROJECT IN OREGON AND WASHINGTON}

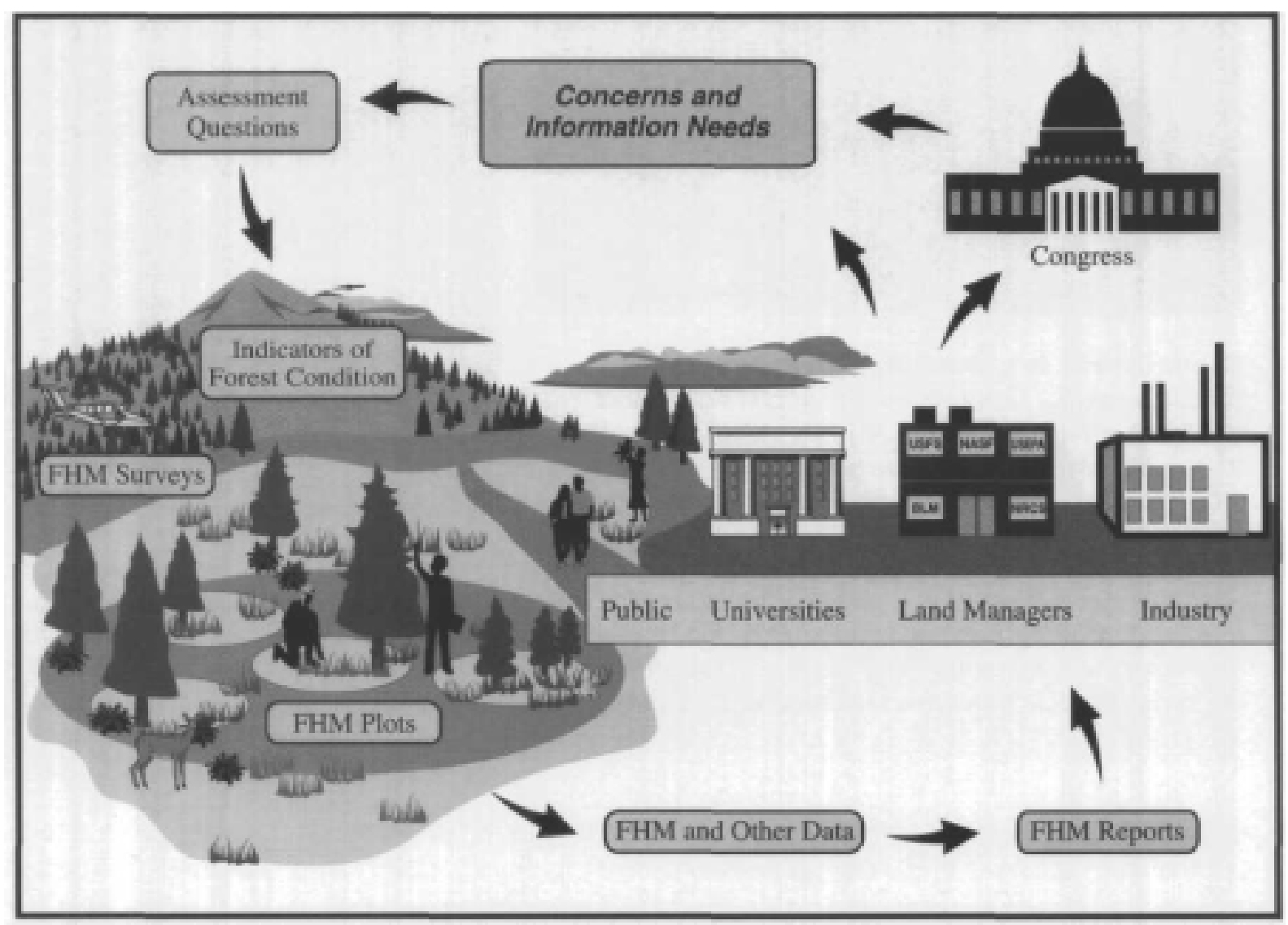

Implementing the national Forest Health Monitoring Program. Step I: measure indicators of forest condition from permanent field plots, aerial surveys, and other ground surveys; Step 2: analyze and interpret the results for various user groups; Step 3: determine how existing and future information can be used to answer specific (assessment) questions about forest ecosystems at national and regional scales.

The Forest Health Monitoring Program is a multiagency national effort to monitor, assess, and report on the long-term status, changes, and trends in forest ecosystem health in the United States. (See appendix 4 for definitions of the kinds of forest health monitoring activities.) Data from permanent field plots and other sources are used to prepare annual summaries and periodic regional and national reports on forest health for the general public, universities, resource managers, and Congress. Some important national and regional assessment questions that can be answered from uniformly collected field data are:

- What proportion of the Nation's forests has reduced growth from past records?

- Where are the risks of reduced growth increasing or decreasing?

- Is the scenic quality of forests decreasing because of more observed damage? 


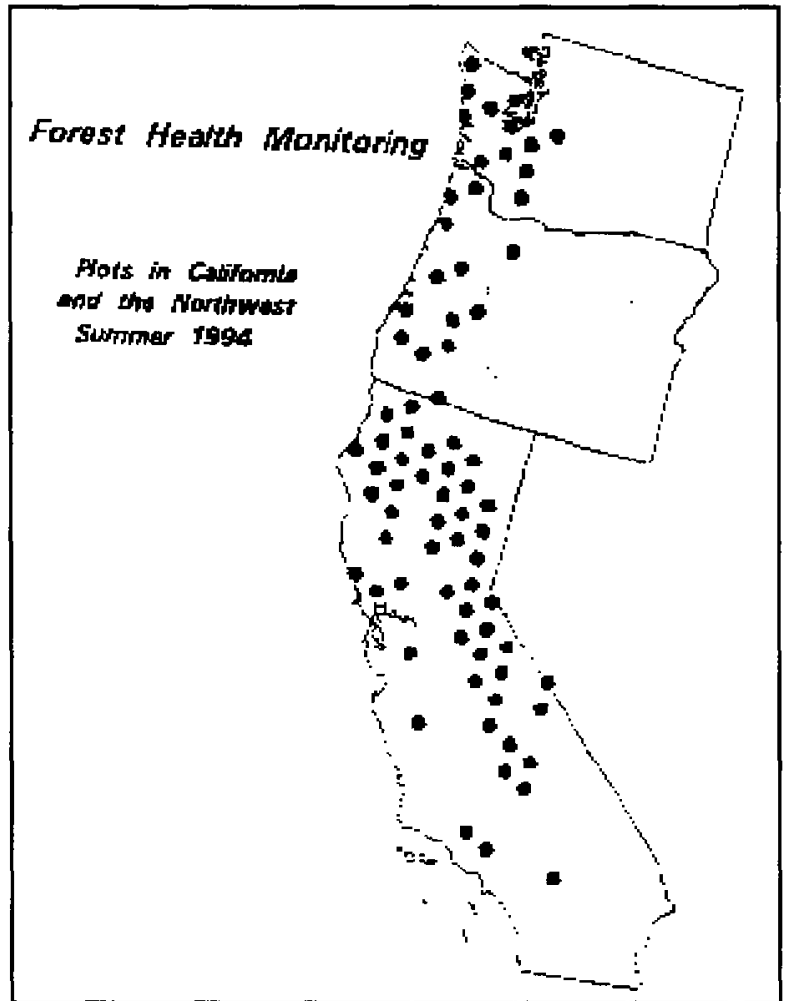

Forest Health Monitoring 1994 field plots in California, Oregon, and Washington.

In summer 1994, Forest Health Monitoring protocols were used to sample forest conditions of Douglas-fir habitats in Oregon and Washington, from the Cascade Range crest westward to the Pacific Ocean. This work tested the ease of measuring various indicators of forest health in environmental conditions wetter than those in California. It also familiarized state forestry cooperators with field protocols they would be using in their forest health monitoring work and established baseline conditions for Douglas-fir forests related to the different indicators measured. Establishing and interpreting baseline conditions (see appendix 4) is critical to reviewing management options for oldgrowth stands and adaptive management areas. Results from this work, hereafter called the Pilot Study, are explained in the rest of this chapter. Many forest health monitoring indicators (table 5-1) have been tested for 6 years in regional pilot studies across the United States. The following sections define those
Table 5-1-Forest Health Monitoring indicators to assess forest ecosystem condition

Indicators

Growth

Crown condition

Leaf area

Plant species composition

Lichen community structure

Bioindicator plants

Songbird habitat

Nitrogen index

\author{
Indicators cont \\ Regeneration \\ Mortality \\ Tree damage \\ Soils:
}

Acidification index

Organic carbon status

Disturbance recovery index indicators measured in the Pilot Study, describe results from field sampling, and interpret their significance for Northwest forests. When possible, Pilot Study results are compared to 4-year Forest Health Monitoring data from about 200 plots measured in California, 1992 to 1995.

\section{GENERAL SITE AND SPECIES CHARACTERISTICS}

Twenty-five plots, each about 2.47 acres, were sampled in the Pilot Study-12 in Washington and 13 in Oregon. Elevations ranged from $<30$ feet to about 7,600 feet. Stand ages ranged from $<10$ to 300 years. Oregon sites were older, at higher elevations, and on steeper slopes than Washington sites; aspects varied across both states. Conifers were the dominant vegetation. As expected, the predominant forest type on the 25 plots was Douglas-fir

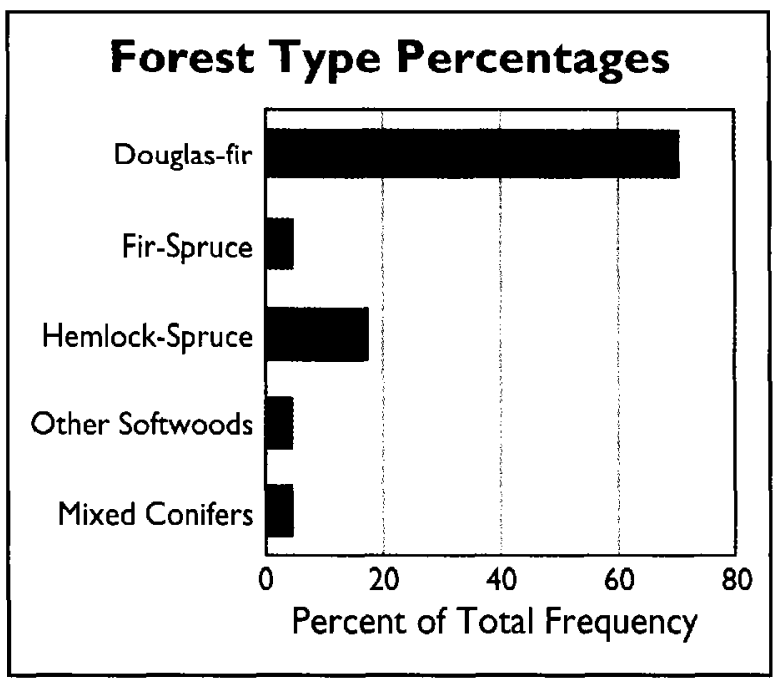


(70\%), followed by hemlock-spruce (17\%); some plots had small amounts (about $4 \%$ each) of fir-spruce, mixed conifer, or other softwoods.

\section{Stand Characteristics}

Each forest stand has unique understory and overstory traits distinguishing it from other stands with similar or different species. Together, these traits are called stand character-

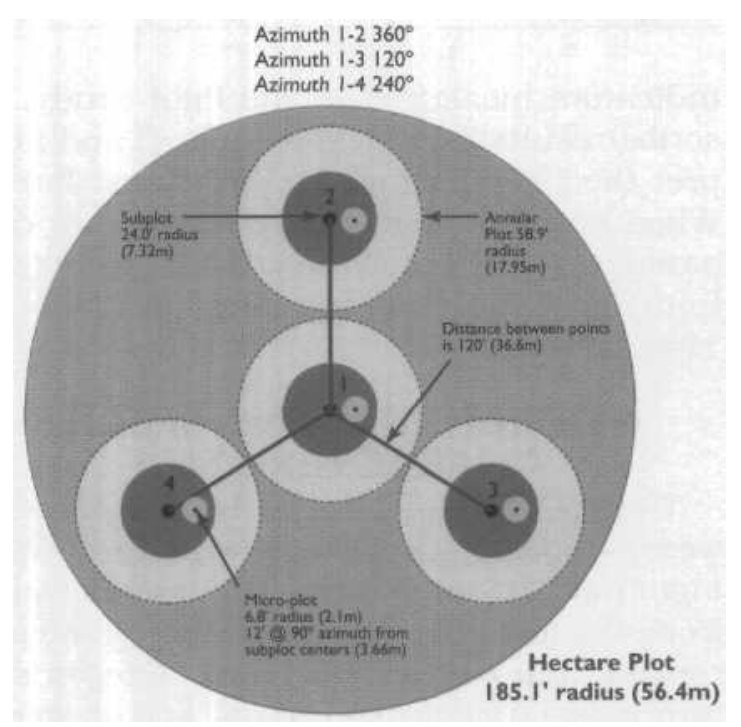

National FHM plot layout is designed around four points (subplot centers)

Forest Health Monitoring field plot layout.

istics. Tree and seedling characteristics at Pilot Study sites were measured in four circular microplots and subplots of known size, permitting results to be calculated per unit area. Economic, scenic, and biodiversity values can then be attributed to larger landscapesized areas, allowing resource managers to decide between different management options.

\section{Understory Vegetation}

Presence and abundance of understory cover indicate status of seedling regeneration, percentages of various vegetation ground cover, and which ground cover may be competing with new or established seedlings for soil moisture and nutrients. Understory measurements were taken in small microplots, at right angles

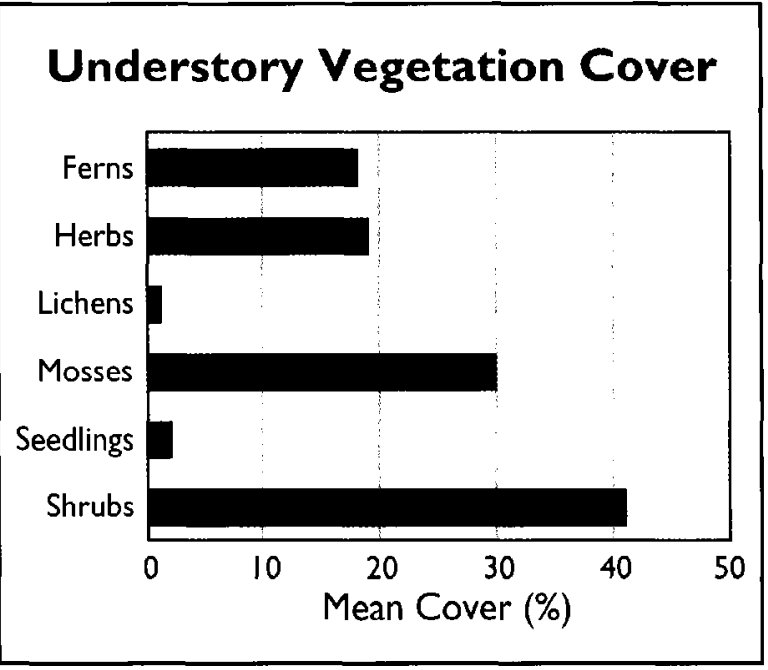

to each subplot. Ground-cover percentages for Pilot Study sites are shown in the figure above.

Pilot Study plots had about the same percentage cover for herbs, lichens, and seedlings as did the 1992-95 California plots. Shrub cover was twice, fern cover was nine times, and moss cover was ten times higher in Pilot Study plots. Pilot Study seedlings seem to face greater competition from shrubs and ferns than do plot seedlings in California, probably because of wetter growing conditions.

\section{Overstory Vegetation}

Forest managers commonly summarize characteristics of small and large trees-saplings, poles, and sawtimber-growing above the forest floor and having similar height and diameter limits (table 5-2). Seedlings and saplings were recorded within microplots and pole and sawtimber-sized trees within subplots. Field tallies showed 79 sapling, 448 pole, and 275 sawtimber trees.

$\begin{aligned} & \text { Table 5-2-Size classes } \text { of forest ecosystem } \\ & \text { components }\end{aligned}$
$\begin{array}{ll}\text { Class } & \text { Range limit } \\ \text { Understory seedling } & <1 \mathrm{ft} \text { tall } \\ \text { Seedlings } & >1 \mathrm{ft} \text { tall } \&<1.0 \text { inch diameter } \\ \text { Saplings } & >1.0 \text { to } 4.99 \text { inch diameter } \\ \text { Poles } & 5.0 \text { to } 10.99 \text { inch diameter } \\ \begin{array}{l}\text { Sawtimber } \\ \quad \text { (hardwood and softwood) }\end{array} & \text { at least } 11.0 \text { inch diameter }\end{array}$

\section{Monitoring-68}


The average number of subplot saplings found in 1992-95 California plots, four individuals, was almost the same as the average for the Pilot Study plots, three individuals. Pilot Study sites, however, had one-third more pole (18 vs. 12 individuals) and about twice as many sawtimber trees (11 vs. 6 individuals). More plot and unit-area pole and sawtimber trees in Oregon and Washington (table 5-3) probably reflect older stands that have more overstory trees. Washington plots had characteristics of younger stands compared to Oregon plots: twice the number of saplings and about 1.5 times as many poles.

\begin{tabular}{|c|c|c|}
\hline \multirow[t]{2}{*}{ Data } & Oregon & Washington \\
\hline & \multicolumn{2}{|c|}{ Number of trees per acre } \\
\hline Saplings & 78 & 159 \\
\hline Poles & 45 & 63 \\
\hline Sawtimber & 33 & 34 \\
\hline Totals & 156 & 256 \\
\hline
\end{tabular}

\section{Basal Area}

Basal area is a measure of the total crosssectional area of tree boles at breast height in square feet. The higher the value, the more cross-sectional area is occupied by bole wood. How the bole wood is partitioned, however, determines economic value as well as influences habitat diversity. If large total basal area is spread over many very small stems, they are probably not merchantable for posts, poles, or pulp. Many small old stems produce densely shaded stands that do not usually allow growth of thick understory vegetation.

The average live basal area combined for poles and sawtimber was 204 square feet/acre in Oregon, and 154 square feet/acre in Washington. These values are well within ranges typically found in managed and unmanaged stands (table 54). Higher values in Oregon reflect those for older stands. In the California 1992-95 data, live basal area averaged about 96 square feet/ acre, including pole and sawtimber trees for all species.

\section{Table 5-4-Basal areas typically found for different species and age classes in Northwest forests}

\section{Species}

(age range in $\mathrm{yr}$ )

Douglas-fir (0-750)

Western hemlock (100-500+)

Western redcedar (100-500+)

Red alder (0-100)

Bigleaf maple (100-400)

\section{Basal area ranges} (ft2/acre)

20-180+

40-180

$0-80+$

$0-20$

$0-20$

\section{CROWN RATINGS}

Many factors affect seedling and tree growth: internal factors are vigor and age of the plant and external ones are light, water, and nutrients. Light reaching a tree or seedling is influenced by the individual's position in the canopy; relative position to neighbors; and the shape, size, and condition of the crown. Thus, crown evaluations indicate whole tree condi-

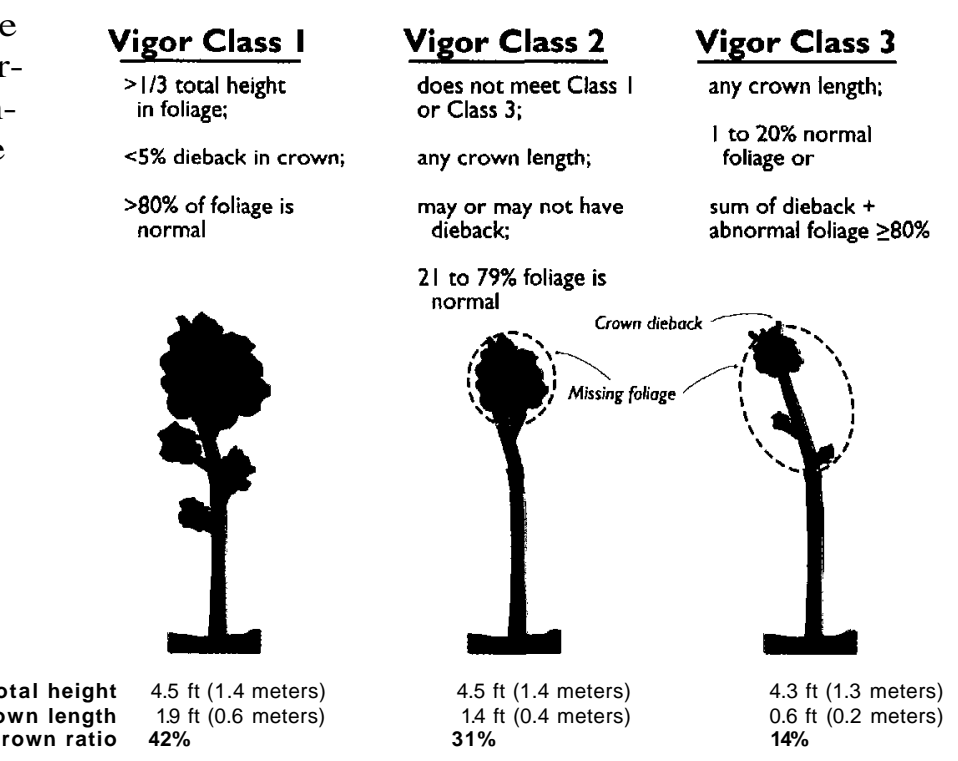

Sapling crown vigor classes. 

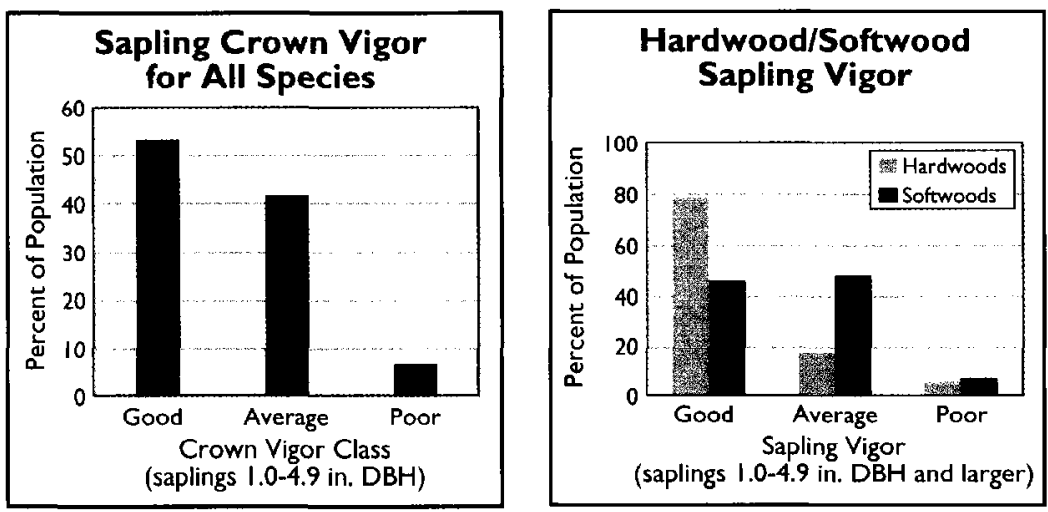

tion by indirectly assessing its ability to capture light and produce carbohydrates by photosynthesis. Crown condition indicators used in this report are sapling crown vigor, crown density, crown dieback, and foliage transparency.

\section{Sapling Crown Vigor}

Sapling crown vigor was evaluated for 79 saplings. High ratings in the good and average categories (vigor class

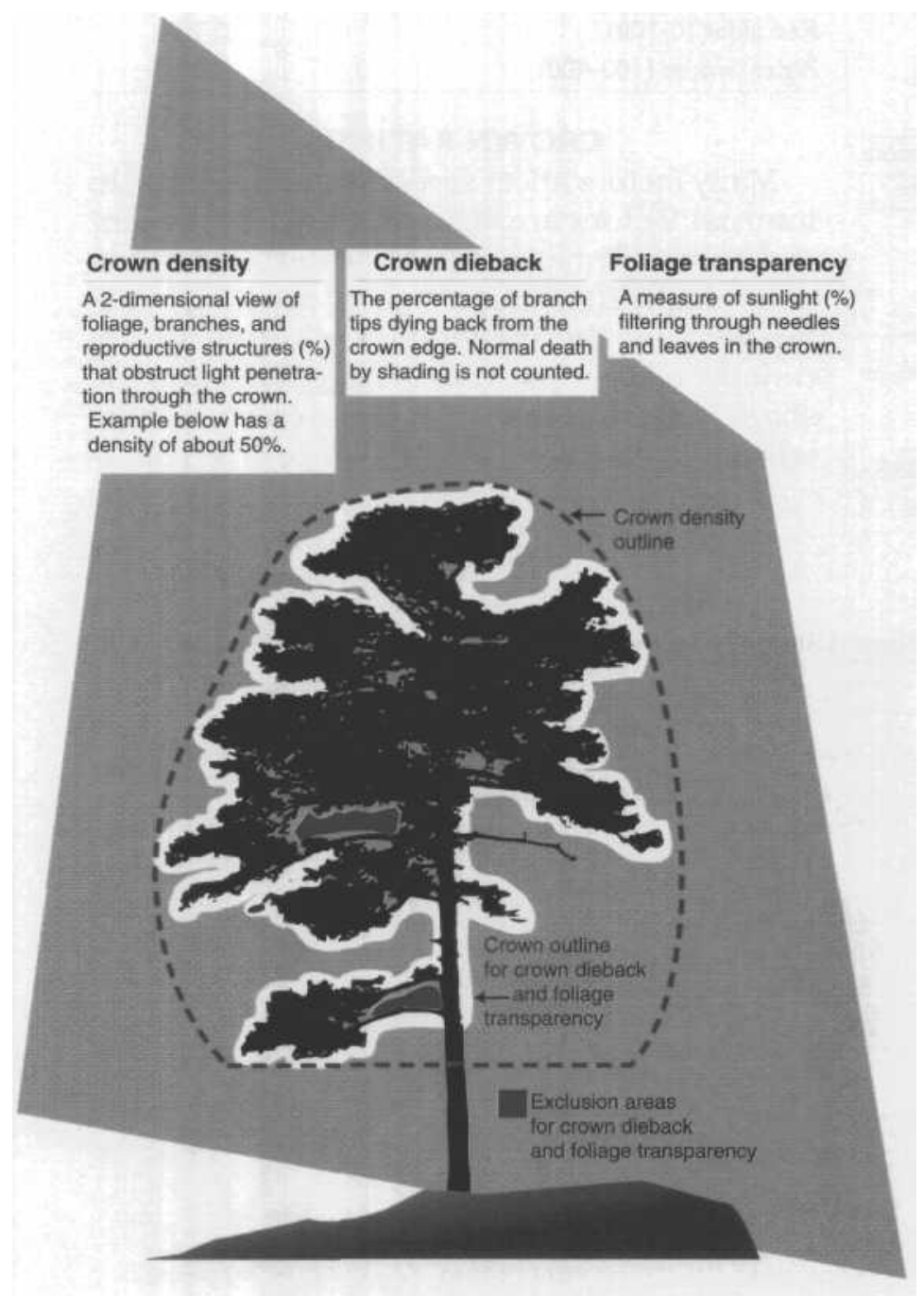

1 and vigor class 2) indicate more foliage area available for photosynthesis. Across all species, the sum of good and average sapling vigor was $94 \%$; only five saplings $(6 \%)$ had poor vigor (vigor class 3). Almost twice as many hardwood saplings had good vigor compared to softwood saplings, but the sum of good and average vigor for both was $>90 \%$. Over $90 \%$ of all saplings in the Pilot Study and California 1992-95 plots had high (good + average) crown vigor ratings.

\section{Crown Density}

Crown density represents the relative amount of foliage, branches, and reproductive structures that obstruct skylight visibility through the crown. Young and old trees with vigorous growth generally have full crowns and high density values-a condition indicating more foliage area available for photosynthesis. Including all species and trees, $96 \%$ of $\mathrm{Pi}-$ lot Study trees had high (good + average) crown density ratings. Hardwoods had a lower percentage of good ratings but a larger percentage of average ratings. These findings were similar for all trees and species by state. The lower percentage of good ratings in Oregon probably reflects lower vigor of older stands sampled there.

Crown density, crown dieback, and foliage transparency rating example.

\section{Monitoring-70}



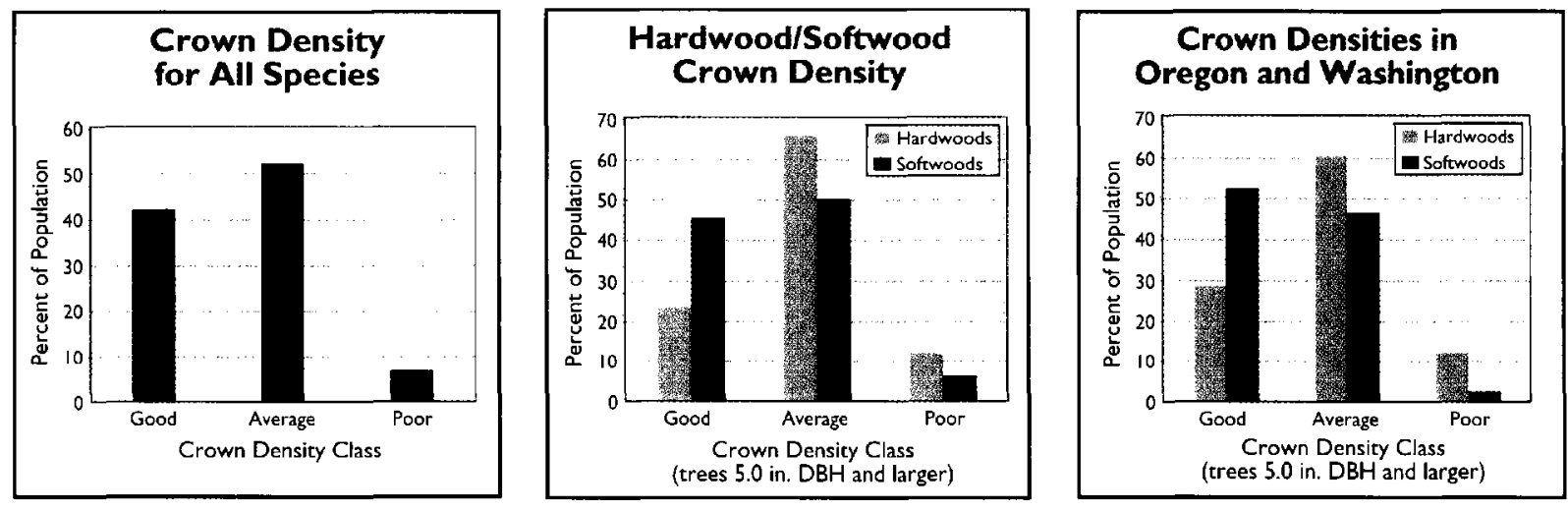

\section{Crown Dieback}

Crown dieback is the total percentage of branch tips dying back from the crown perimeter, except dieback caused by shading and competition from neighboring trees. Dieback is caused by severe shock to root systems from drought

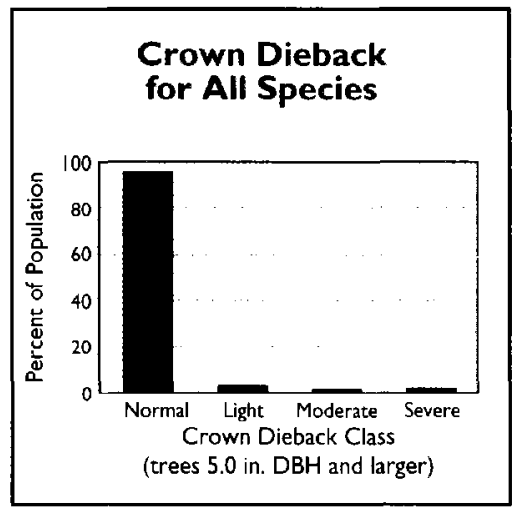

or disease. Some species also will show light dieback as part of their normal growth, but too much dieback reduces foliage area available for photosynthesis. No crown

dieback was detected on $95 \%$ of Northwest Pilot Study trees. The no-damage class was split about equally between hardwoods and softwoods. By state, percentages of trees with none, light, moderate, and severe ratings were almost identical to those ratings when all Pilot Study trees were combined.

In the Pilot Study, western hemlock comprised $1 \%$ of the total population's severe dieback and the "Other Hardwoods" class had $6 \%$ severe dieback. In the 1992-95 California data, oaks comprised

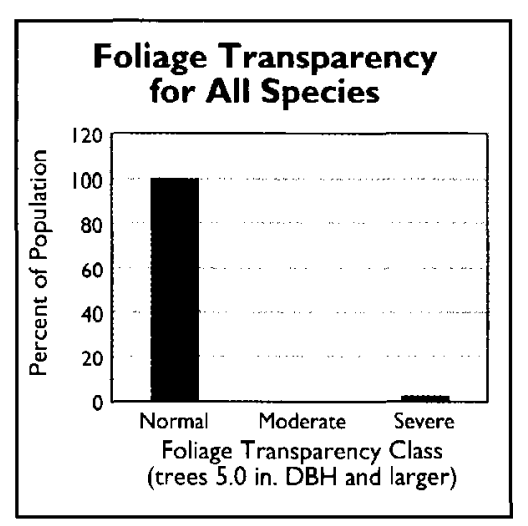

about $1 \%$ and fir-spruce about $1.5 \%$ of plot trees with severe dieback. Severe dieback was noted for all major species groups in the 4 years of California data, but some species were affected more in certain years. For example, Douglas-fir, oak, redwood-sequoia, and true fir all had severe dieback in 1992 - the end of a 7-year drought. Only oaks in 1993 and 1994 and only oaks and pine in 1995 had severe dieback.

\section{Foliage Transparency}

Foliage transparency measures light filtering through needles and leaves in the crown. Transparency values differ by species and depend on natural branching habit and foliage orientation. High transparency values indicate unhealthy crown conditions because less foliage area is available for photosynthesis. Reduced foliage area can be caused by insects, disease, and other stressors. In Pilot Study plots, $98 \%$ of all trees had normal $(0-30 \%)$ transparency ratings. A slightly higher per-

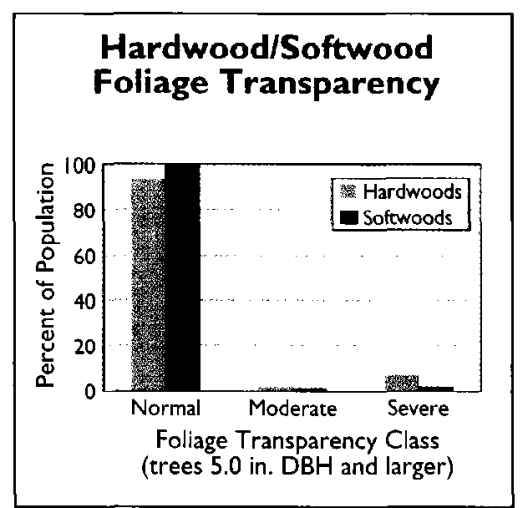


centage of softwoods than hardwoods had normal transparency ratings; this trend was reversed for moderate (31-50\%) and severe $(>50 \%)$ transparency classes. By state, about $98 \%$ of all trees had normal transparency ratings. Trees in both Pilot Study and the 199295 California plots had almost identical high percentages $(>95 \%)$ of trees with good and moderate transparency ratings.

\section{DAMAGE}

Pathogens, insects, air pollution, and other natural or human disturbances can affect tree growth and development. Damage caused by any agent, alone or in combination, can influence forest condition. Recording observable damage signs and symptoms provides valuable information to assess forest condition and to interpret any deviations from baseline conditions. Field crews recorded damage symptoms seen in field plots when the observed damage could kill the tree or affect its long-term survival.

Damage codes have two parts: the general location of injury and the damage type (table 5-5). Data are recorded for all live microplot saplings and all subplot live trees. Trees are observed from all sides, starting at the roots. Priorities are set for damage signs and symptoms and recorded by general location in the following order: roots, roots and lower bole, lower bole, lower and upper bole, upper bole, crown stem, branches, buds and shoots, and foliage. The numeric order (table 5-5) denotes decreasing significance as the code number goes up-for example, damage code 02

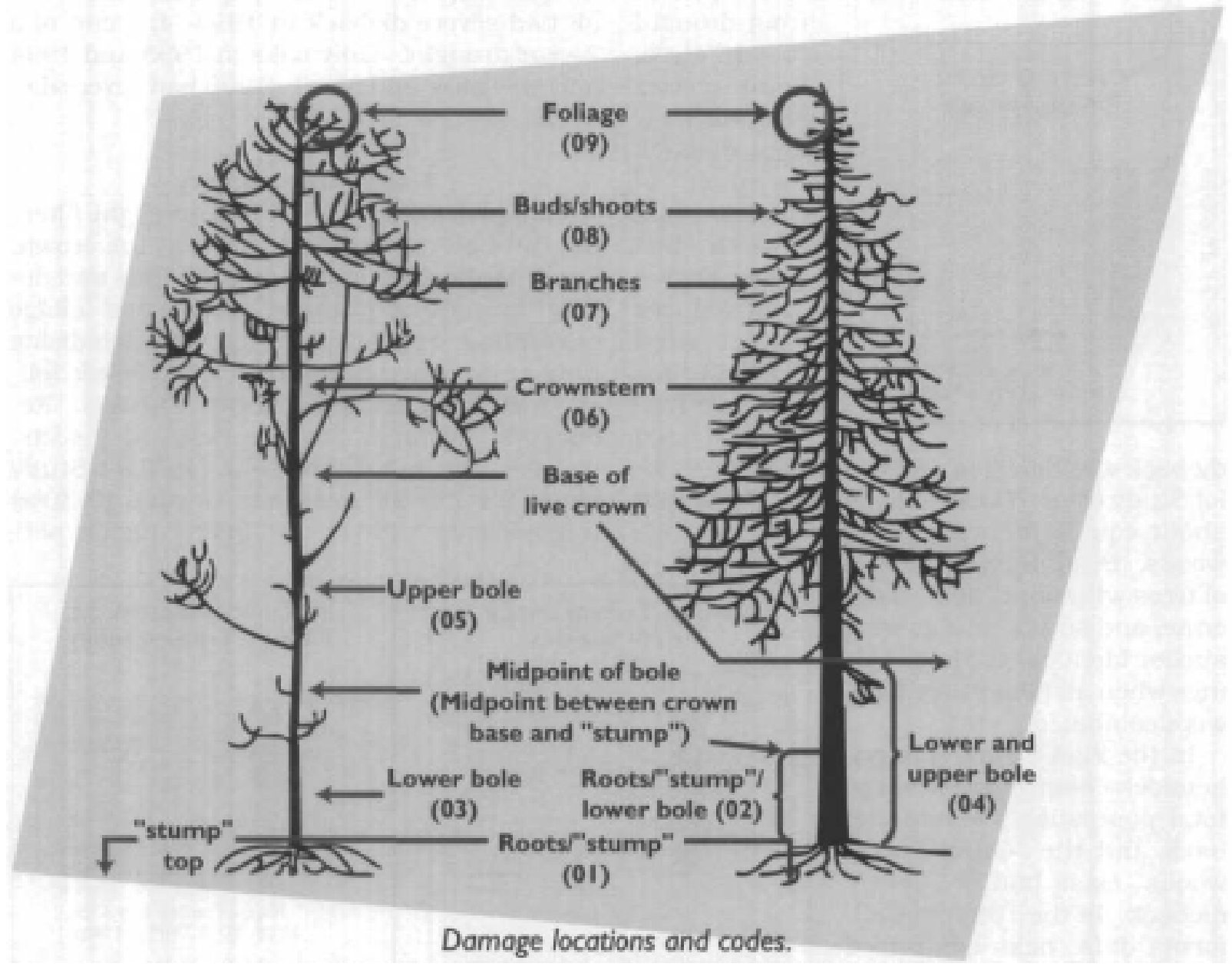

Monitoring -72 
Table 5-5-Damage types recorded in the 1996 Pilot Study

$\begin{array}{llc}\begin{array}{l}\text { Damage } \\ \text { code }\end{array} & \text { Description } & \begin{array}{c}\text { Severity threshold percentage } \\ \text { (in 10\% classes to 99\%) }\end{array} \\ 01 & \text { Canker } & 20 \\ 02 & \text { Conks, fruiting bodies, and other indicators } & \text { None } \\ 03 & \text { Open wounds } & 20 \\ 04 & \text { Resinosis or gummosis } & 20 \\ 11 & \text { Broken bole or roots <3 ft from bole } & \text { None } \\ 12 & \text { Brooms on roots or bole } & \text { None } \\ 13 & \text { Broken or dead roots, >3 ft from bole } & 20 \\ 21 & \text { Loss of apical dominance; dead terminal } & 1 \\ 22 & \text { Broken or dead branches } & 20 \\ 23 & \text { Excessive branching or brooms } & 20 \\ 24 & \text { Damaged foliage or shoots } & 30 \\ 25 & \text { Discoloration of foliage } & 30 \\ 31 & \text { Other } & \text { None }\end{array}$

About $80 \%$ of the Pilot Study trees and $75 \%$ of California trees had no damage symptoms. The no-damage percentage for California reserve (national parks, wilderness) and drier woodland areas, however, was about $60 \%$. The most common damage symptoms were conks, dead terminal branches, and open wounds, which together represented about $10 \%$ of all trees. Conk damage, indicating interior fungal decay in the tree bole and stem, was the greatest single damaging agent both in the Pilot Study and the 1992-95 California plots. The no-damage percentage of about $80 \%$ for all trees across all three states was not anticipated because tree species, climate, environments, disease, and insect factors differ so widely from north to south along the Pacific Coast. The lower 60\% no-damage value for reserve and woodland land classes in California means that older stands or more stressed environments have a lower no-damage baseline. A major deviation from these nodamage baseline values of 60 and $80 \%$ will indicate presence of one or more significant stressors.

\section{FULL-HECTARE TALLY}

The full-hectare (2.47 acre) tally is done only in the Pacific Northwest and in California, at the request of federal and state cooperators who provide additional funding for its implementation. Need for the extra tally arose in summer 1991 when a California pilot plot in a sequoia forest had no recently dead or live large trees in any of the four subplots. Because the overstory of many Northwest forest types has similarly large trees, the concern of California, Oregon, and Washington state cooperators was that subplots would not capture a representative number of large live and dead trees. Thus, protocols were changed so that field crews searched the entire 2.47-acre plot area for both large recent dead trees ( $>11.0$ inches) 


\section{Subplot vs I.0-hectare Tallies}

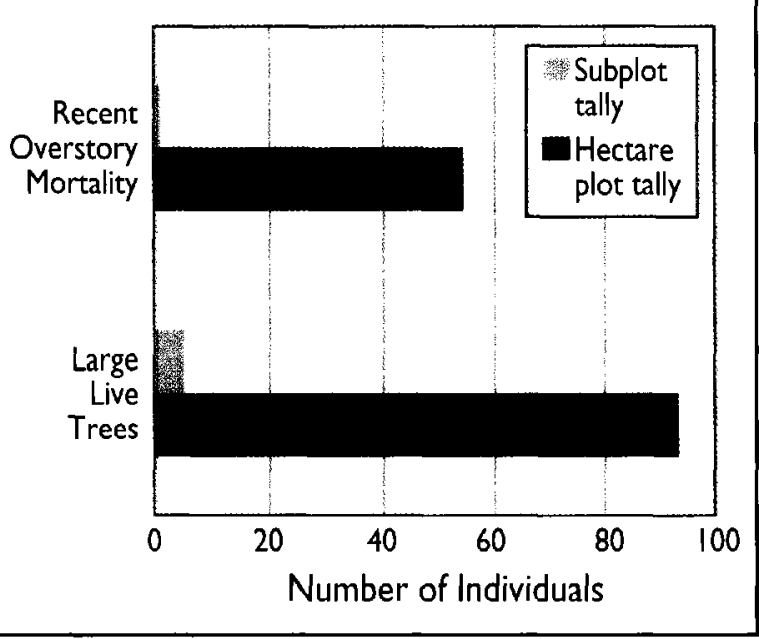

that had died in the last 5 years and large live trees (>40 inches).

Pilot Study subplots had almost no recent mortality (1 vs. 55$)$ and few large live trees (5 vs. 93) compared to numbers tallied on fullhectare plots. More large live trees were found on 25 plots in Oregon and Washington in 1994 than were recorded for almost 200 California plots measured in 1992-95. Pilot Study field work was restricted to Douglas-fir habitats in western Oregon and Washington. These forests have a high percentage of large-diameter trees not tallied in subplot-only data. The significance of this work is that larger plots will be needed to characterize true overstory conditions in Oregon and Washington forests when operational field work starts in the future. Published results for 1992-95 California forest health monitoring data show that per area estimates of recently dead trees based on subplot-only data were significantly different than estimates made from the full-hectare tallies.

\section{VEGETATION STRUCTURE}

Vegetation structure indicators provide information on species composition, relative cover amount, and spatial distribution of vascular plants in the forest. Vegetation measurements help describe plant biodiversity and quantify habitat structure, which in turn in- fluences wildlife biodiversity and distribution in forest ecosystems. Vegetation structure indicators provide a natural link to other indicators including songbird habitat, crown condition, regeneration, and species diversity.

Vegetation observations and collections are taken in 10.8-square-foot permanent quadrats; each subplot has three quadrats. Three kinds of information are taken for each quadrat: species identification, height class in which each species occurs, and plant canopy cover. Data were collected for four strata: stratum 1 is from the ground to 2 feet; stratum 2 is from 2 to 6 feet; stratum 3 is from 6 to 16 feet; and stratum 4 is from 16 feet to the forest canopy. Botanists worked from the lowest stratum upward and used a calibrated range pole and the quadrat frame to define the sample area. Specimens of unknown plants were collected outside the subplots, dried, pressed, labeled, and submitted to the Oregon State University Herbarium, Corvallis, for identification.

Some 193 species were identified in 25 Pilot Study plots. Eleven species were found at 9 or more of the 25 sample sites (table 5-6). As expected, ground and understory layers (strata 1 and 2) had the most species and highest number of observations per species. Stratum 4 had the greatest total cover and the fewest species.

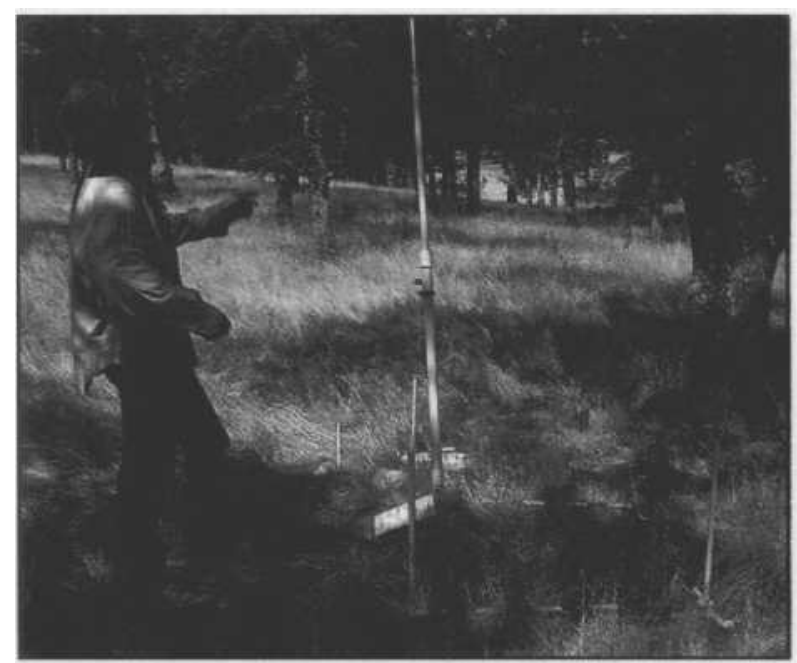

Botanists collect vegetation structure information in subplot quadrats. 


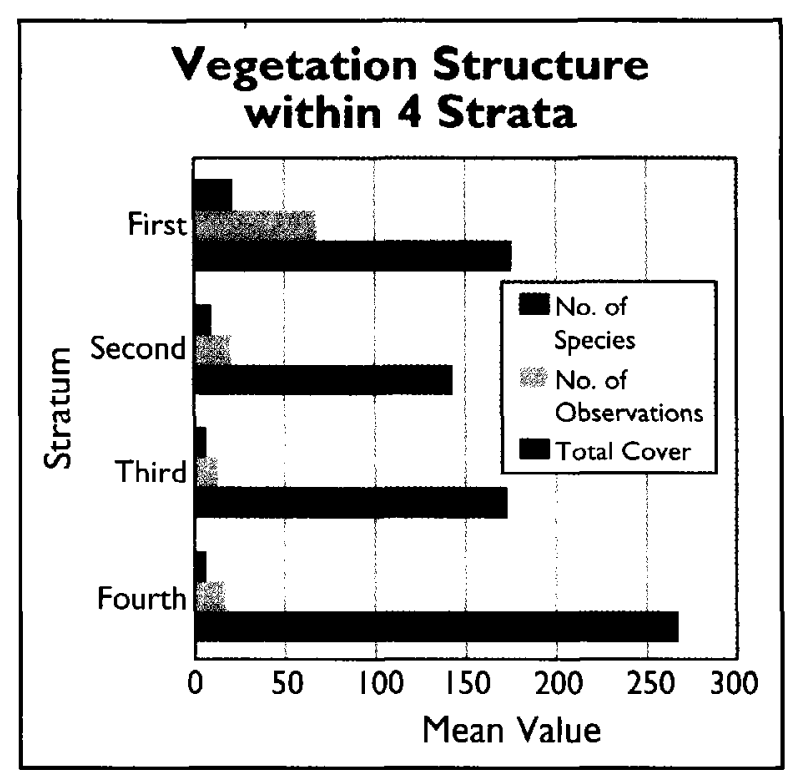

\section{LICHEN COMMUNITIES}

Lichen communities provide information about several key monitoring questions such as contamination of natural resources, biodiversity, and sustainability of resource production. Hundreds of papers published worldwide in the last century document the close relation of lichen communities to air pol-

$\begin{array}{lc}\text { Table 5-6-Most common plant species } & \\ \text { Common name } & \text { Sites (no.) } \\ \text { Acrobolbus } & 9 \\ \text { Red alder } & 9 \\ \text { Twin flower } & 10 \\ \text { Oregongrape } & 10 \\ \text { Red blueberry } & 10 \\ \text { Western salal } & 13 \\ \text { Starflower } & 13 \\ \text { Pacific blackberry } & 16 \\ \text { Western hemlock } & 16 \\ \text { Sword fern } & 17 \\ \text { Douglas-fir } & 20\end{array}$

lution, especially nitrogen and sulfur-based pollutants. Sensitivity of epiphytic lichens apparently results from their lack of a cuticle

'Adapted from: Cooperative Agreement Report: Lichen communities-Pacific Northwest Pilot Study, 1994. Peter Neitlich, Bruce McCune, and Jeri Peck, Botany Department, Oregon State University, Corvallis, OR. 1996. 9 p.

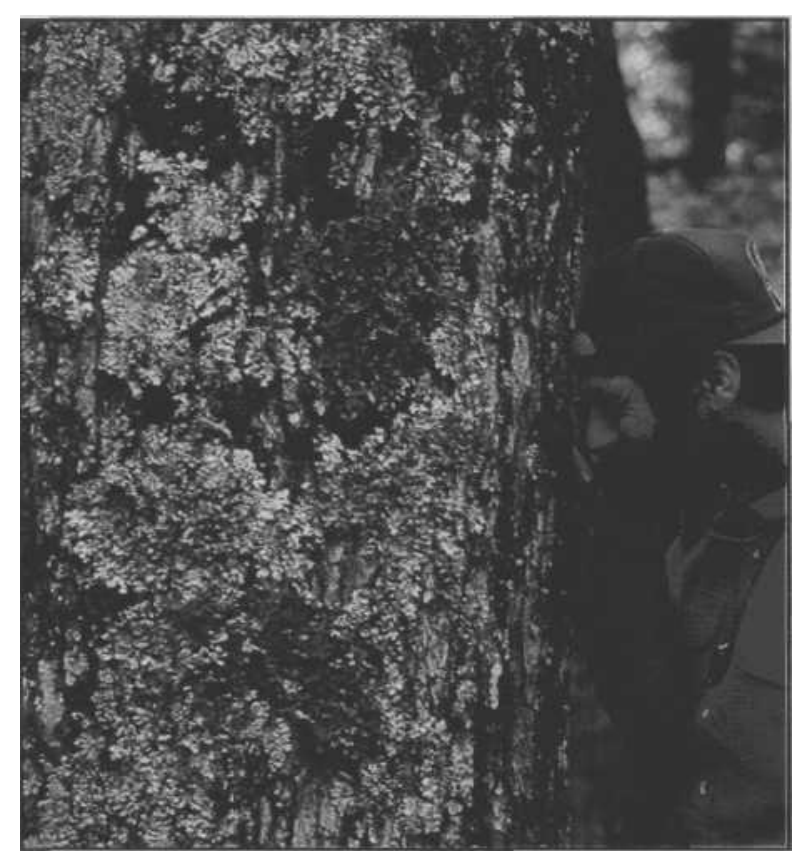

\section{Macrolichens on woody substrate.}

and their total reliance on atmospheric sources of nutrition. Lichens thus provide a direct indication of air pollution effects and can be indirectly related to forest productivity.

Because lichens are linked to several human-induced environmental stressors, they may be a key indicator of general forest condition. To test this idea, lichens have been sampled in forest health monitoring plots in several regions of the United States since 1990. Sampled flora is restricted to macrolichens on living or standing dead woody substrates. Small microlichens are excluded because they are difficult to sample. These collection restrictions standardize measurements to a class of substrates that can be found at all sites. For example, lichens are usually abundant and diverse on rocks but many field sites have no surface rocks.

Field workers collected macrolichens on woody plants, excluding the 1.6-foot basal portions of trees and shrubs. They estimated abundance of each species using a four-step scale. Accurately assigning species names to collected lichens was not necessary because all specimens were sent to a specialist for identification. 
The total number of species found in Oregon and Washington combined was 82. Species richness (the number of species per plot) ranged from 7 to 30 and averaged 15. At least 8 species were found on $>50 \%$ of 25 field plots ${ }^{2}$. General conclusions from the lichen collection work were:

- The lichen community sampling method was used effectively in the Pacific Northwest without altering methods used in other regions of the United States.

- Species richness values found in the Pilot Study were somewhat lower than those found in the Southeast, higher than in Colorado, and similar to California.

- Methods appear to be fairly repeatable across sites, but some differences between observers emphasized that good training and quality-assurance checks are needed to achieve a good representation of all species present.

- Results can be used to evaluate biological effects of deteriorating air quality after a regional air-quality model is implemented, as has been done in other regions.

\section{SONGBIRD HABITAT INDICATOR ${ }^{3}$}

Populations of many songbird species are strongly influenced by local forest structure, which affects microclimate, availability of foraging and nesting sites, and risk of predation. In addition, because some forest birds are sensitive to the size and shape of forest stands, their presence or absence can reflect habitat quality at broader scales. Songbird communities can thus act as indicators of the effects of forest disturbance.

During the summer of 1994, songbird surveys were conducted in conjunction with vegetation measurements on 60 study sites in the Cascade Range of western Oregon and Wash-

\footnotetext{
${ }^{2}$ The eight most common species and their percentage occurrence across 25 plots were Hypogymnia enteromorpha, $60 \% ; H$. inactiva, $52 \% ; H$. physodes, $72 \%$; Parmelia sulcata, $72 \%$ : Platismatia glauca, $80 \%$; P herrei, 52\%; Ramalina farinacea, 52\%; and Usnea spp.,

${ }^{3}$ Adapted from: Cooperative Agreement Report: Wildlife habitat indicator-Pacific Northwest Pilot Study Report. Grant E. Canterbury and Thomas E. Martin, Montana Cooperative Wildlife Research, University of Montana, Missoula, MT. 1995. $11 \mathrm{p}$.
}

ington. Forests on these study sites were dominated by Douglas-fir and western hemlock. The goals of this study were to collect data on bird communities along a forest disturbance gradient, develop habitat models to predict bird community composition from vegetation parameters measured by Forest Health Monitoring crews, and test bird survey methods that had previously been used successfully in southeastern pine forests.

Four 50-meter-radius bird survey plots were established at each site. Plot centers were 492 feet apart, covering an area of about 15 acres, so the probability of detecting the same individual birds on more than one plot was low. Measurements included number and species of birds seen within each plot, estimated canopy cover, shrub density, understory vegetation, and sapling and tree data. Sites ranged from recent clearcuts to old-growth forests. A recorder conducted 20-minute bird surveys at each plot between 6:00 and 10:00 AM, except during rainy or windy weather which could interfere with detection of birds.

Because songbirds are easily surveyed and show a variety of responses to forest habitat structure, the species on a site can be used to indicate the effects of forest disturbance on bird communities. In the Pacific Northwest, two groups of 16 disturbance-sensitive species and 16 disturbance-tolerant species were identified from the ornithological literature (table 5-7). Each group responds primarily to major forest disturbances such as clearcutting or agricultural clearing rather than relatively minor disturbances such as ground fires and selective cutting. Bird species intermediate in habitat preference between disturbed and mature forests were not assigned to either group.

A Bird Community Index indicating the degree to which forest bird communities are altered by disturbance was developed from a modified ratio of species abundance in the two disturbance groups. The Bird Community Index was strongly influenced by vegetation characteristics on the study plots. About two-thirds of the variability in Bird Community Index val- 
Table 5-7-Songbird and habitat relations in Douglas-fir ecosystems

Disturbance tolerant

Dark-eyed junco

MacGillivray's warbler

Rufous hummingbird

American robin

Spotted towhee

Orange-crowned warbler

House wren

Black-headed grosbeak

Northern flicker

Song sparrow

White-crowned sparrow

Willow flycatcher

Olive-sided flycatcher

Fox sparrow

Lazuli bunting

Warbling vireo
Disturbance sensitive

Hermit warbler

Townsend's warbler

Winter wren

Chestnut-backed chickadee

Pacific-slope flycatcher

Golden-crowned kinglet

Red-breasted nuthatch

Steller's jay

Hammond's flycatcher

Varied thrush

Hairy woodpecker

Gray jay

Pileated woodpecker

Red-breasted sapsucker

Red crossbill

Brown creeper

ues was explained by a model including two vegetation variables: deciduous and coniferous canopy cover.

This study indicates that the field methods used to survey songbirds and their habitat in the southeastern United States also work in the Pacific Northwest. A preliminary model now exists to use Forest Health Monitoring vegetation data to predict Bird Community Index values for a stand. Thus, local habitat structure can indicate whether bird communities should be dominated by species typical of mature forests or those typical of disturbed, early-successional habitat. These predictions can be checked in the field against actual bird communities to validate the model and determine whether other factors such as climate or regional fragmentation of forests are also affecting bird populations.

\section{CONCLUSIONS}

Limited baseline data from forest health detection monitoring now exist for Douglas-fir habitats in 13 Oregon and 12 Washington Pilot Study plots sampled west of the Cascade Range in the summer of 1994. Cooperators in both states learned regular and quality-control protocols needed to remeasure these plots

and start statewide future operational measurements. All indicator measurements were successfully completed with field methods tested in 18 states, including California, since 1990. The total Pilot Study data set is small, and interpretations must be used with caution.

Seedling and lichen ground-cover percentages ( 1 to $4 \%$ ) were similar in Pilot Study and about 200 California plots sampled in 199295. Wetter environments and older stands in the Northwest probably produced higher ground percentages of ferns $(18 \%)$, mosses $(35 \%)$, and shrubs $(41 \%)$ plus more pole- and sawtimber-sized trees. Most Pilot Study saplings had either good or average vigor, indicating good general health; some differences were found between hardwood and softwoods. More than $95 \%$ of all Pilot Study trees had good crown ratings as shown by normal foliage transparency, good to average crown density, and little severe dieback. Differences in Pilot Study and California crown ratings were minimal. Similarly, about $80 \%$ of sampled individuals across all three states had no damage symptoms. Conks, broken tops and branches, and decay indicators were the most common damage classes.

Forest canopies throughout the Northwest have many large dead and live trees. Such trees were successfully tallied in large full-hectare (2.47-acre) plots but not in small subplots. Remeasurement and future work in Pacific Coast states will require using larger plots. Vegetation structure data were collected for four strata in all plots. The greatest number of individuals and species were tallied in those strata (1 and 2) nearest the ground. Lichens were found in all plots; the average number of macrolichens per plot was 15. A songbird habitat study produced a model that can use vegetation structure data from Forest Health Monitoring plots to predict whether expected birds will be typical of mature or disturbed forest types. 


\section{CHAPTER 6. THE FUTURE OF OREGON AND WASHINGTON FOREST HEALTH}

People, as part of the natural environment, have always used forests for their needs. These needs have changed over the years, from generation to generation, and will change in the future. And, at any one time, different uses will be championed by different people. What is perceived to be healthy, or not, may differ between users. But no matter what the forests are used for, they can be considered healthy when disturbance agents, such as fire, insects, and pathogens, remain within limits set by the variability of natural ecosystems. Put another way, forest health is the condition where disturbances not only do not threaten management objectives but work to maintain desired, sustainable ecosystems.

Management, monitoring, research, and public education are the keys to restoring, maintaining, and improving forest health.

- Management, or manipulation of the forest by various practices, is a valuable tool to help reach a desired outcome within a specified period. A variety of management options to improve forest health in Oregon and Washington are described below.

- Monitoring is necessary to establish initial forest conditions (the "baseline") and to detect changes in those conditions. During implemention of new or untested strategies, monitoring helps determine whether those strategies produce the desired effect.

- Research is an ongoing need in forest management. Shifts in the focus from stand management to watershed and river basin management require new understanding of the relations between forest organisms and how management practices might affect these organisms individually and collectively over entire landscapes.

- Public education and educational programs are needed to promote understanding of the complexities of forest health and their relations to forest resources, uses, and management activities.

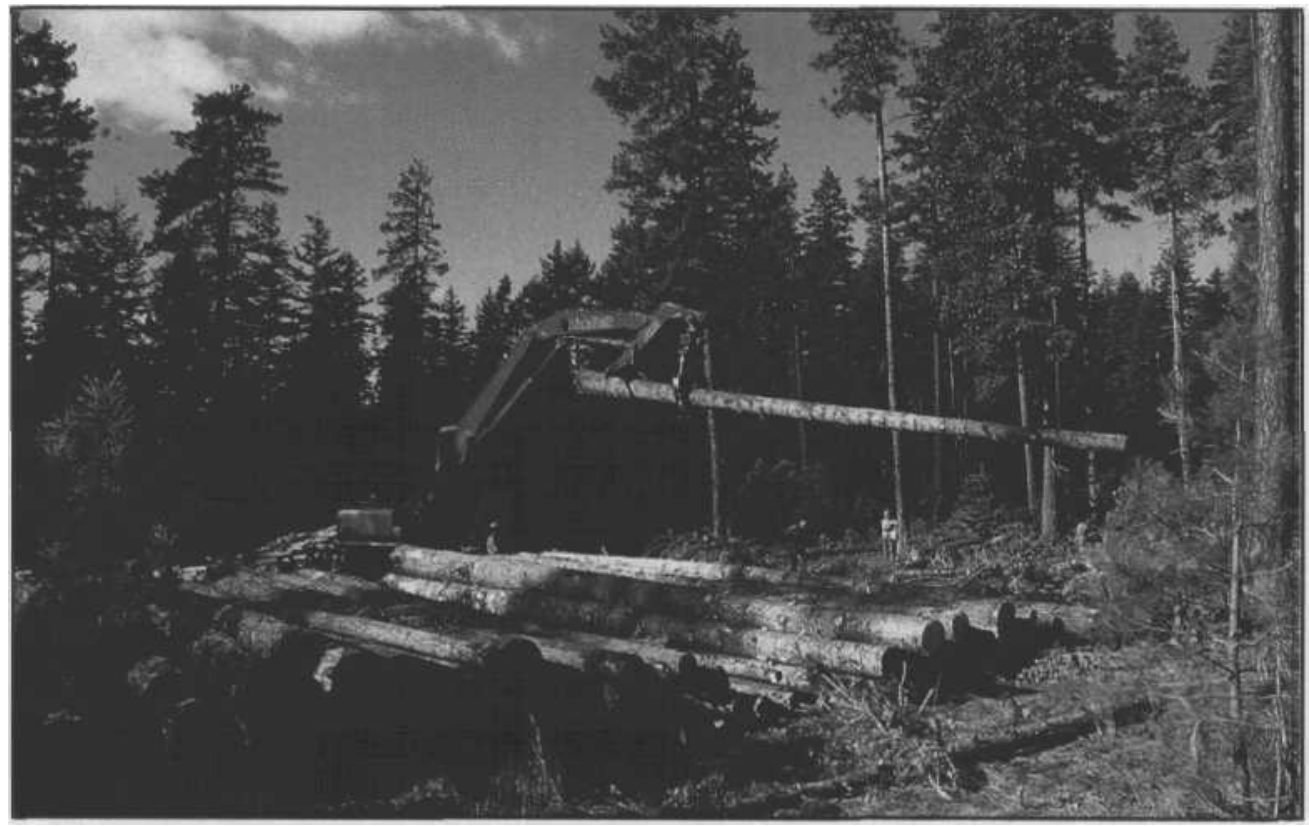

Thinning reduces competition, stress, and bark beetle susceptibility. 


\section{EAST OF THE CASCADES}

Healthy or not?-Forest conditions in eastern Oregon and Washington have been steadily changing for more than 100 years. Many disturbances in forest stands have altered frequencies or intensities compared to historical ones, often outside the natural range of variation. Much of the change in disturbance regimes is due to fire suppression and selective harvesting in the last century. Both practices have resulted in significant changes in the distribution and structure of forest vegetation: more true fir and Douglas-fir on low-elevation sites where pines and larch formerly predominated, many overstocked mixed conifer and pine stands, and more multistoried stands. Key differences between historical and present disturbance patterns are described below:
- Outbreaks of defoliating insects, such as western spruce budworm and Douglas-fir tussock moth, are now larger, more intense, and more frequent.

- Bark beetle mortality, associated with tree stress and overstocked stands, is more prevalent.

- Drought periods in the late 1980 s and early 1990s, coupled with overstocking, contributed to increased susceptibility to insects, diseases, and fire.

- Many root diseases and dwarf mistletoes are more widespread and destructive because of changes in forest structure and past harvest practices.

- Fire is less frequent now but much more devastating on lower elevation, dry sites. The fire hazard on these sites is higher because of fuel buildup.

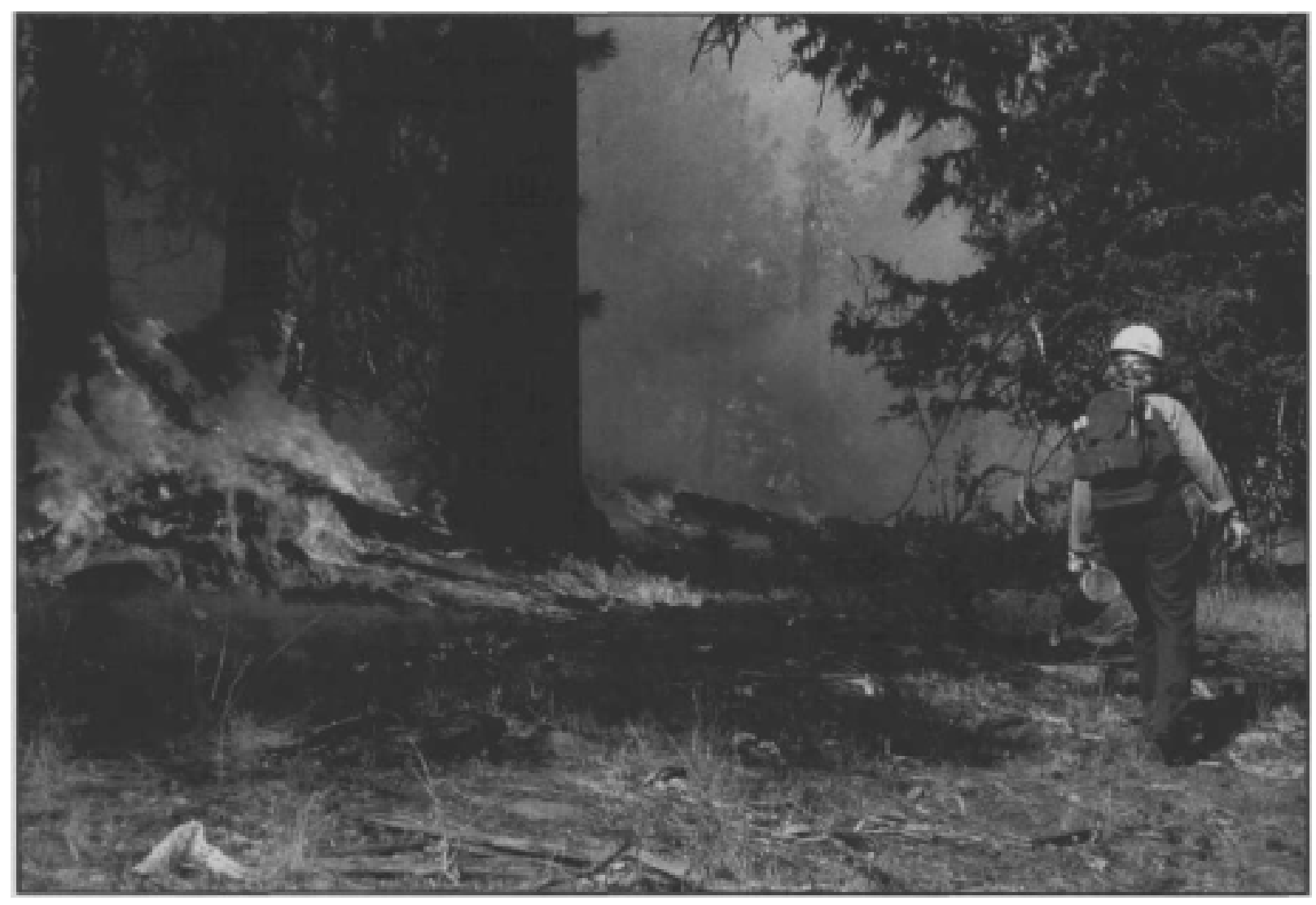

Prescribed fire reduces fuels and thins the stand by killing some of the smaller and more firesusceptible tree species. 
Solutions - Although the current forest conditions are accepted as "normal" by many, we believe these east-side forests are unhealthy and in need of renewal and restoration. Resource managers and land owners have several options for managing their forests to achieve long-term forest health. Prescriptions for harvest, stand improvement, riparian restoration, or wildlife enhancement can be tailored to improve forest health and, at the same time, to achieve resource management objectives. There are a number of ways to return sites to historical, or other desirable, conditions to reduce their susceptibility to fire, insects, pathogens, and drought:

- Thin stands to reduce competition, stress, and bark beetle susceptibility.

- Harvest certain species such as lodgepole pine to create a mosaic of age classes across the landscape to prevent widespread outbreaks of bark beetles.
Design site-specific regeneration (natural or planted) to promote desired species composition.

Keep in mind the effects that various activities (such as thinning, harvest, or replanting certain species) will have on root diseases and dwarf mistletoes.

1 Reduce fuel loading to decrease destructive, stand-replacing fires. Once fuels are reduced to manageable amounts, prescribed fire can be used more safely and effectively.

1 Introduce prescribed fire that mimics natural light ground fires to maintain a low fuel load; remove fire-susceptible species such as Douglas-fir and true fir; and use fire to regenerate species such as larch or quaking aspen that depend on fire or other disturbance to create appropriate seedbeds or stimulate root sprouting.

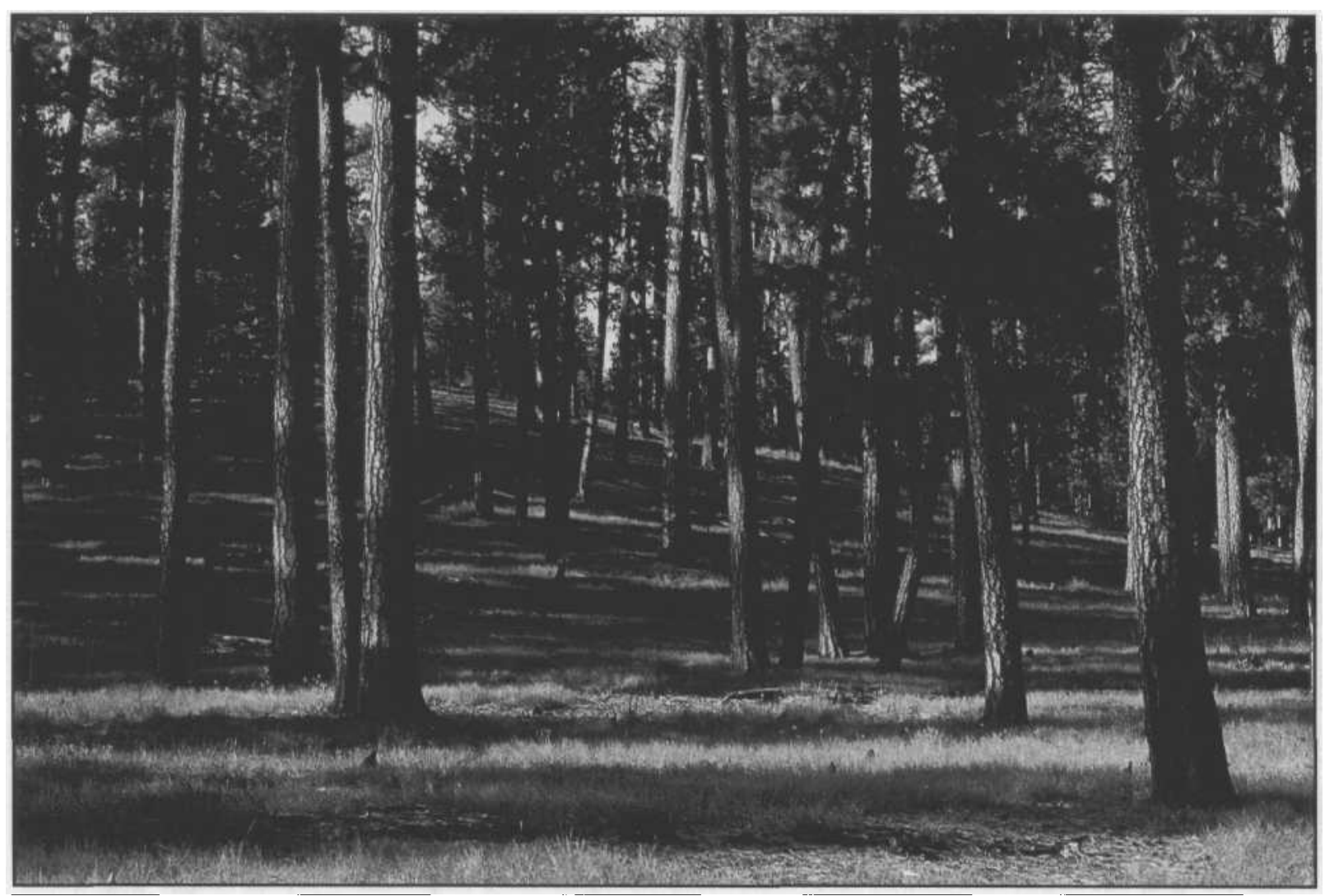

Several years after thinning and prescribed fire.

The Future- $\mathbf{8 0}$ 
Reducing Bark Beetle Damage in eastern Oregon and Washington. When sufficient susceptible host material is available, bark beetle populations can become primary pests, capable of killing otherwise healthy host trees. Outbreaks subside when suitable host material is depleted. We recommend the following actions to minimize bark beetle damage:

- Keep trees well-spaced and, therefore, vigorous; thinning changes stand structure, disrupts beetle movement, and increases vigor in residual trees.

- Thin or clearcut lodgepole pine stands approaching 60 to 80 years of age or 8 to 10 inches in diameter. A long-term strategy for reducing damage from mountain pine beetle in lodgepole pine is to maintain a mosaic of age classes, preventing the whole landscape from being covered with uniform, highly susceptible stands at the same time.

- Remove or destroy trees that currently contain bark beetles before the spring after the initial attack. Trees that have been killed by bark beetles generally do not perpetuate risk of additional insect or disease damage to the stand after the first year.

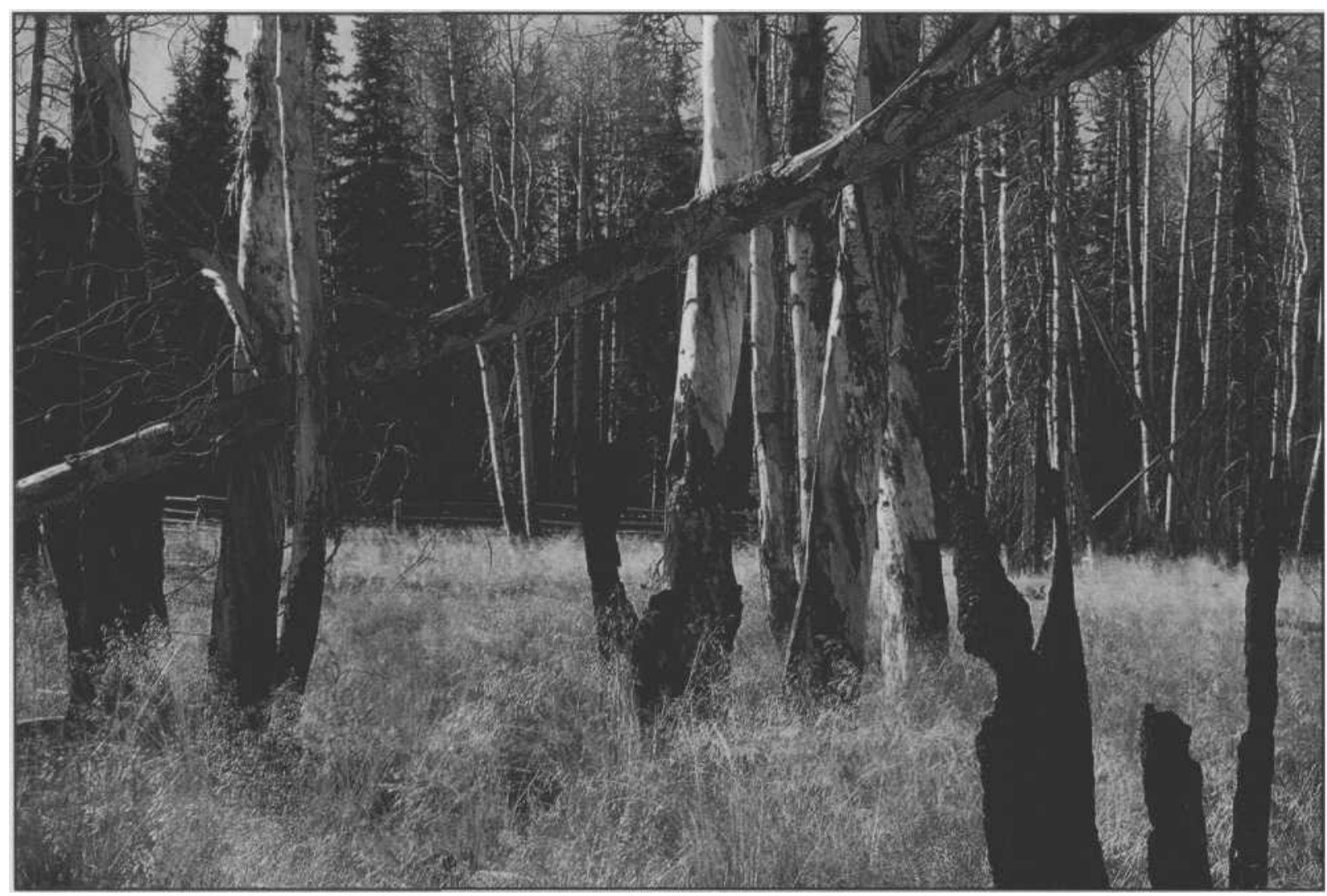

Quaking aspen needs fire to successfully regenerate from the roots of burned, killed trees. 
Minimizing effects from defoliators. Factors that favor survival of western spruce budworm, Douglas-fir tussock moth, and hemlock looper include stands with a predominance of host species, mature stands with large crowns and many nutritious reproductive buds, and a multilayered canopy with host species in both the overstory and understory. We recommend the following actions to improve stand and host tree resistance to defoliators:

- Maintain a diversity of seral forest stages with mixed host and nonhost species.

- Where feasible, convert mixed stands of Douglas-fir, true fir, and associated species threatened by defoliators to stands composed primarily of Ponderosa pine, western white pine, and smaller proportions of western larch and Douglas-fir.

- Maintain or manage for reasonable stocking density.

- Maintain or manage for low vertical diversity.

\section{WEST OF THE CASCADES}

Healthy or not?-Natural forests in western Oregon and Washington have been reduced and fragmented by urbanization and logging in the last half-century. Widespread harvest and replanting have reduced diversity of species and structure in many areas. But, unlike in east-side forests, changes in natural disturbance regimes are neither as widespread nor as dramatic. The continued good health of west-side forests is, however, still threatened by the following changes:

- Incidence and damage by native forest pathogens, particularly root diseases, have increased because of past forest management practices.

- Introductions of exotic pests have risen dramatically over the past century with increased commerce, travel, and new people moving to the Northwest.

- Air pollution has worsened in the Willamette Valley and Puget Sound areas with increased population and industry. Ozone and other pollutants can damage forests near and far from pollutant sources.

- Periods of drought have contributed to susceptibility of trees to attacks by insects and pathogens.

- Stresses on urban trees from air pollution, mechanical injury, and poor maintenance, have increased in many cities and towns.
- Fire, wind, and disease are hazards to trees, people, and homes in the urban-forest interface.

Solutions - Improving forest health in western Oregon and Washington can be approached from two directions: maximizing forest management options and minimizing urban impacts.

In forested areas on the west side, resource managers and land owners have several options for managing their forests to achieve long-term forest health. Although restoration efforts over large areas are not usually called for, changes at a smaller scale can be beneficial. Some strategies for forest health improvement in western Oregon and Washington include the following:

- Shift stands from single species to multiple species to reduce insect outbreaks and proliferation of diseases. Tradeoffs between maximizing timber production (traditionally with even-aged, single-species plantations) and minimizing insect and disease damage must be examined.

- Replant harvested or restored areas with seedlings grown from local seed sources or use natural regeneration. Severity of diseases such as Swiss needle cast is much less when trees are adapted to the site.

- Maintain a mosaic or mix of species and age classes, preventing the whole landscape from being dominated by uniform, highly susceptible stands. 
Is root disease more common now than in the past? In general, root diseases were probably less frequent and in smaller centers in the past than currently. Why?

- Harvesting root-diseased trees left infected roots in the ground and increased chances for contact with roots of healthy trees.

- Regeneration of root-disease-susceptible species has been encouraged.

- Compaction on sensitive soils has reduced vigor of residual trees, leaving them more vulnerable to armillaria root disease.

- Fire suppression has favored root-disease-susceptible species.

- Injury of roots and lower stems during harvest operations can attract insects that spread black stain root disease in susceptible hosts.

- Creation of more stumps has resulted in more habitat for some root disease fungi.

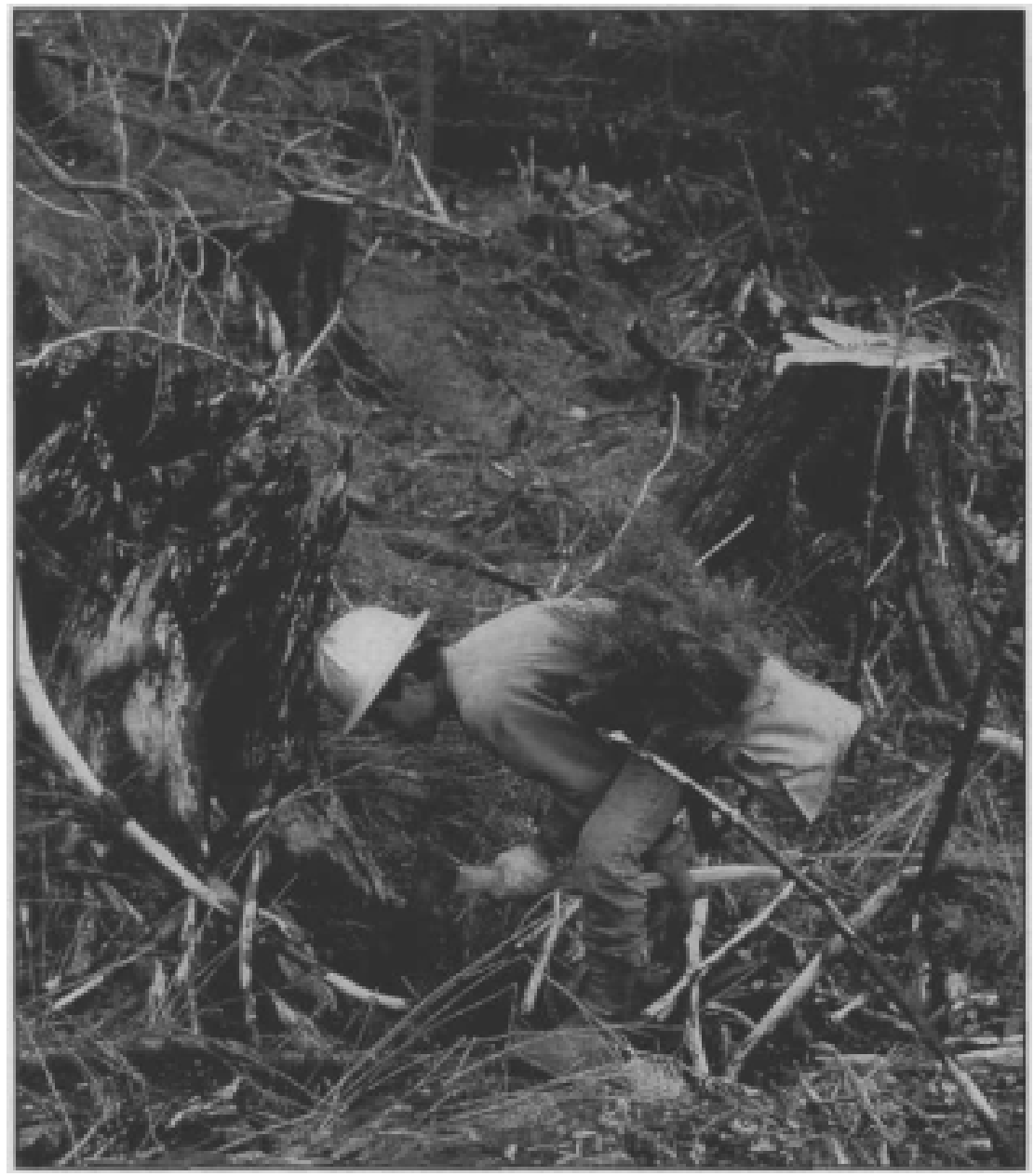

Insect and disease damage can often be reduced by planting seedlings of resistant or tolerant species and using local seed sources. 
The effects of people on west-side forests can be lessened several ways. As the population in the Northwest grows, the following remedial or preventive actions become ever more crucial to forest health:

- Reduce air pollution through a variety of strategies and new technology so that production of ozone and other pollutants that damage forests can be reduced or, at the very least, not increased.

- Maintain programs to monitor and eradicate exotic pests, and to prevent new introductions. Where exotics already are established, prevention activities, such as the resistance breeding program for white pine blister rust, are crucial to the survival of native tree species.

- Plant and care for trees and other vegetation in urban areas. Use species adapted to the local climate and able to withstand stresses associated with an urban environment.

- Manage for hazards such as fire, decay, and root disease in urban-forest interfaces.

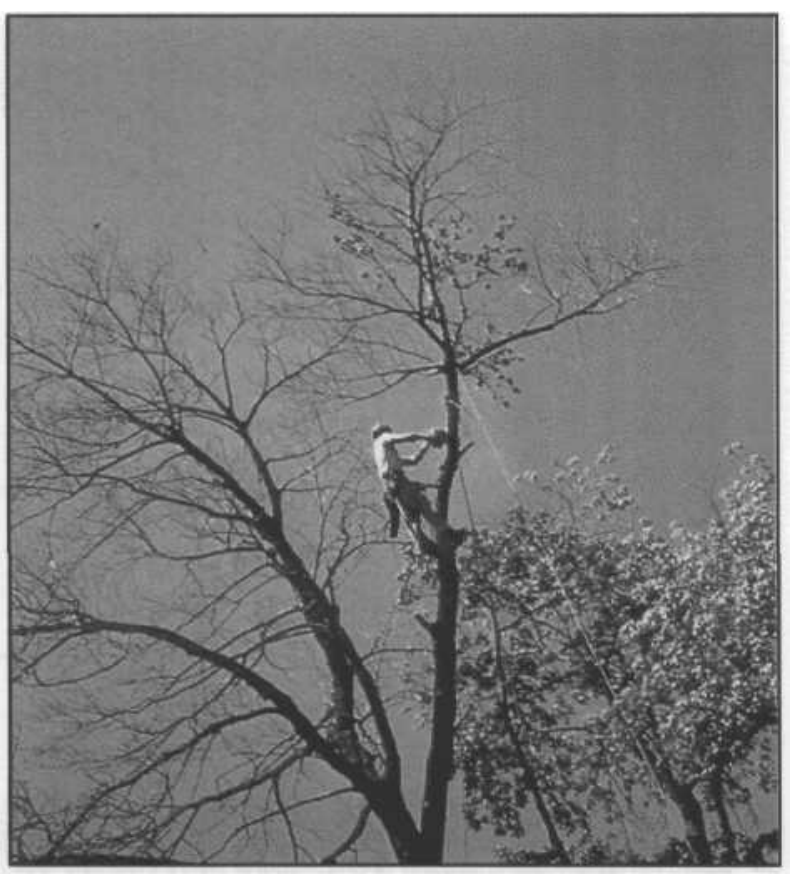

Urban tree selection and care are important to ensure longevity and safety of community trees.

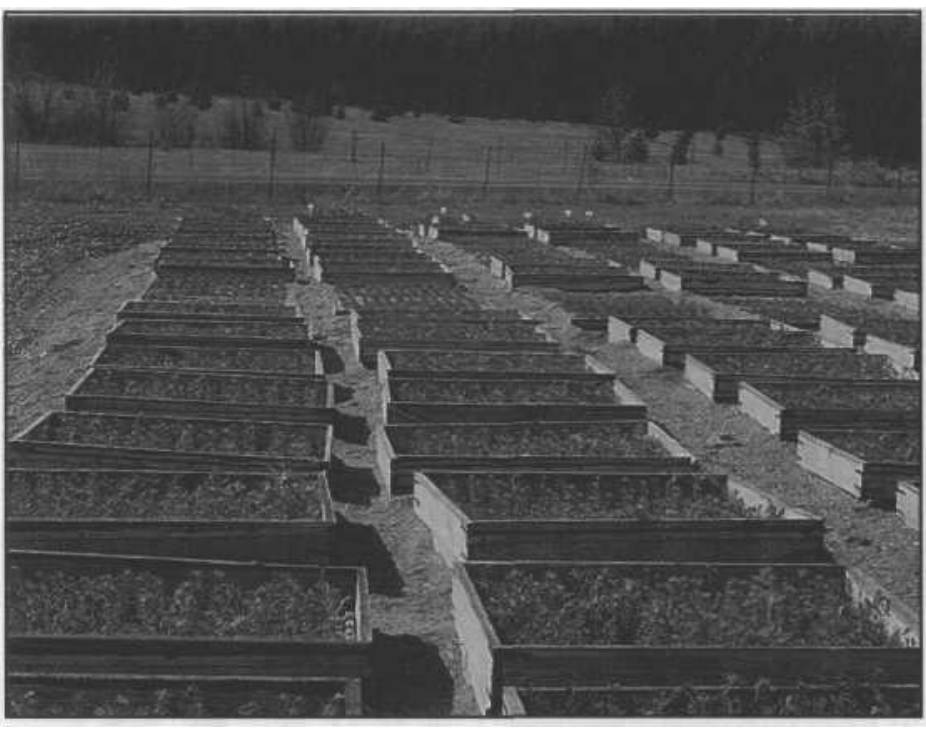

The white pine blister rust resistance breeding program in Cottage Grove, Oregon, inoculates thousands of white pine and sugar pine seedlings with blister rust to find a few resistant individuals that can be propagated.

\section{SOUTHWEST OREGON}

Conditions and changes in disturbance patterns over the past century in southwest Oregon share similarities with both eastern and western Oregon and Washington. The effects of fire suppression and past harvesting influenced and changed current vegetation conditions, much as they did east of the Cascades. Many sites are overstocked, prone to insect outbreaks, and have high fire hazard. A period of drought in the late 1980s and early 1990s, coupled with overstocking, contributed to susceptibility to insects, disease, and fire. Exotic diseases, such as white pine blister rust and Port-Orford-cedar root disease, have had significant effects on five-needled pines and PortOrford-cedar, respectively, and their management. Strategies for improving forest health are similar to those for eastern and western Oregon and Washington. 
Restoration of five-needle pines. Where western white pine, sugar pine, and whitebark pine are being killed by blister rust and bark beetles, several options are available to improve their vigor and resistance:

- Density management treatments, such as thinning or underburning, increase vigor and make trees less prone to bark beetle attack, particularly in stands with large sugar pines.

- Underburning to maintain clear ground for seed hiding by birds is essential for whitebark pine regeneration.

- Rust-resistant western white pine and sugar pine is available to be planted on sites where risk of blister rust infection is high.

\section{THE FUTURE}

Citizens, forest owners, and resource managers must all become active to solve forest health problems in Oregon and Washington. Without cooperation and interaction among groups with diverse and opposing viewpoints, future needs and desires for products and services from regional forests will not be met.

East of the Cascades, the risks of uncontrollable, stand-replacing wildfires and widespread insect outbreaks are very great unless fuels and tree densities are reduced.

West of the Cascades, the continued introduction of exotic insects, diseases, and plants threaten the existence of native for- ests and, without continual vigilance, chances of establishment and spread are much greater. Air pollution, unless controlled and reduced, will affect increasing numbers of forest species, influencing their ability to grow and reproduce.

On both sides of the Cascades, incidence and severity of many native insects and diseases is closely linked to forest management; awareness of the effects of various activities on insects and diseases is essential to achieving desired forest conditions.

Forest management, forest health monitoring, research, and public education are the tools needed to create and maintain the forests that are so important to the people of Oregon and Washington. 


\section{SELECTED REFERENCES}

Agee, James K. 1993. Fire ecology of Pacific Northwest forests. Washington, DC: Island Press. 493 p.

Bailey, Robert G.; Avers, Peter E.; King, Thomas; McNab, W. Henry, eds. 1994. Ecoregions of the United States (map). Washington, DC: U.S. Geological Survey. Scale 1:7,500,000; colored. Accompanied by a supplementary table of map unit descriptions compiled and edited by McNab, W. Henry, and Bailey, Robert G. Prepared for the U.S. Department of Agriculture, Forest Service.

Benedict, Warren V. 1981. History of white pine blister rust control-a personal account. Rep. 355. Washington, DC: U.S. Department of Agriculture, Forest Service. 47 p.

Busing, Richard T.; Liegel, Leon H.; LaBau, V.J. [In press]. Overstory mortality as an indicator of forest health in California. Environmental Monitoring and Assessment. 85 p.

Dale, John. 1996. California forest health report (in preparation). FPM Rep. San Francisco, CA: U.S. Department of Agriculture, Forest Service.

Franklin, J.F.; Dryness, C.T. 1988. Natural vegetation of Oregon and Washington. Corvallis, OR: Oregon State University Press. 452 p.

Hessburg, Paul F.; Mitchell, R.G.; Filip, G.M. 1994. Historical and current roles of insects and pathogens in eastern Oregon and Washington forested landscapes. Gen. Tech. Rep. PNW-GTR-327. Portland, OR: U.S. Department of Agriculture, Forest Service, Pacific Northwest Research Station. 72 p.

Liebhold, Andrew M.; MacDonald, William L.; Bergdahl, Dale; Mastro, Victor C. 1995. Invasion by exotic forest pests: a threat to forest ecosystems. Forest Science Monograph $30.49 \mathrm{p}$.

Liegel, Leon H.; Busing, Richard T.; LaBau, V.J. 1996. Evaluating overstory conditions to assess forest health in California. In: Proceedings of the Society of American Foresters national convention; 1995 Oct. 28-Nov. 1; Portland, ME. Bethesda, MD: Journal of American Foresters: 424-425.

Liegel, Leon H.; Busing, Richard T.; Solano, Samuel. 1996. Forest health monitoring (FHM) activities in the WEST, 1992-1995. In: Proceedings of the California Forest Pest Council, 44th Annual Meeting; 1995 Nov. 15-16; Rancho Cordova, CA. Sacramento, CA: Department of Forestry and Fire Protection: xi-xix.

Mavity, Erika; Stratton, Daniel; Berrang, Paul. 1995. Effects of ozone on several species of plants which are native to the Western United States. Report. Dry Branch, Georgia: U.S. Department of Agriculture, Forest Service, Center for Forest Environmental Studies. 61 p.

McNab, W. Henry; Avers, Peter E., comps. 1994. Ecological subregions of the United States: section descriptions. Admin. Publ. WO-WSA-5. Washington, DC: U.S. Department of Agriculture, Forest Service. 267 p.

Sprengel, Keith, comp. 1995. Forest insect and disease conditions, Pacific Northwest Region, 1994. R6-FIDTP-06-95. Portland, OR: U.S. Department of Agriculture, Forest Service, Pacific Northwest Region. 64 p.

Twardus, Dan; Miller-Weeks, Margaret; Gillespie, Andy. 1995. Forest health assessment for the Northeastern Area, 1993. Tech. Rep. NA-TP-01-95. Radnor, PA: U.S. Department of Agriculture, Forest Service, Northeastern Area. 61 p.

U.S. Congress, Office of Technology Assessment. 1993. Harmful non-indigenous species in the United States. Admin. Publ. OTA-F-565. Washington, DC. 391 p.

U.S. Department of Agriculture, Forest Service. 1996. Air resource management: what we have been doing. R6-NR-TP-14-96. Portland, OR. U.S. Department of Agriculture Forest Service, Pacific Northwest Region.

Wickman, Boyd E. 1992. Forest health in the Blue Mountains: the influence of insects and diseases. Gen. Tech. Rep. PNW-GTR-295. Portland, OR: U.S. Department of Agriculture, Forest Service, Pacific Northwest Research Station. $15 \mathrm{p}$. 


\title{
APPENDIX A-COMMON AND SCIENTIFIC NAMES
}

The common and scientific names of the trees, diseases, and insects mentioned in this report are listed in alphabetical order by common name. An asterisk (*) indicates an exotic (nonnative) species.

\section{Trees:}

Alaska yellow-cedar

American elm

Bigleaf maple

Black cottonwood

California black oak

Chinkapin

Douglas-fir

Engelmann spruce

Grand fir

Hybrid poplar

Jeffrey pine

Lodgepole pine

Mountain hemlock

Noble fir

Oregon ash

Oregon white oak

Pacific dogwood

Pacific madrone

Pacific silver fir

Pacific yew

Ponderosa pine

Port-Orford-cedar

Quaking aspen

Red alder

Sitka spruce

Subalpine fir

Sugar pine

Tanoak

Western hemlock

Western larch

Western redcedar

Western white pine

Whitebark pine

White fir

Willow

\author{
Chamaecyparis nootkatensis \\ Ulmus americana \\ Acer macrophyllum \\ Populus trichocarpa \\ Quercus kelloggii \\ Castanopsis chrysophylla \\ Pseudotsuga menziesii \\ Picea engelmanii \\ Abies grandis \\ Populus spp. \\ Pinus jeffreyi \\ Pinus contorta \\ Tsuga mertensiana \\ Abies procera \\ Fraxinus latifolia \\ Quercus garryana \\ Cornus nuttallii \\ Arbutus menziesii \\ Abies amabalis \\ Taxus brevifolia \\ Pinus ponderosa \\ Chamaecyparis lawsoniana \\ Populus tremuloides \\ Alnus rubra \\ Picea sitchensis \\ Abies lasiocarpa \\ Pinus lambertiana \\ Lithocarpus densiflorus \\ Tsuga heterophylla \\ Larix occidentalis \\ Thuja plicata \\ Pinus monticola \\ Pinus albicaulis \\ Abies concolor \\ Salix spp.
}




\section{Diseases:}

Annosus root disease

Armillaria root disease

Black stain root disease

* Dogwood anthracnose

Douglas-fir dwarf mistletoe

* Dutch elm disease

Laminated root rot

Larch dwarf mistletoe

Lodgepole pine dwarf mistletoe

* Melampsora leaf rust (hybrid poplar)

Mountain hemlock dwarf mistletoe

* Port-Orford-cedar root disease

Schweinitzii root and butt rot

Swiss needle cast

Tomentosus root rot

Western dwarf mistletoe (ponderosa pine]

Western hemlock dwarf mistletoe

White fir dwarf mistletoe

* White pine blister rust

\section{Insects:}

* Balsam woolly adelgid

Douglas-fir beetle

Douglas-fir engraver

Douglas-fir tussock moth

Fir engraver

Forest tent caterpillar

* Gypsy moth (European or Asian)

Hemlock looper

Hemlock sawfly

Madrone leafminer

Mountain pine beetle

Oak looper

Pandora moth

Ponderosa pine cone beetle

* Satin moth

Sitka spruce weevil

Spruce beetle

Western pine beetle

Western spruce budworm
Heterobasidion annosiim

Armillaria ostoyae

Leptographium wagneri

Discula destructiva

Arceuthobium douglasii

Ophiostoma ulmi

Phellinus weirii

Arceuthobium laricis

Arceuthobium americanum

Melampsora larici-populina,

M. medusae f.sp. deltoidae

Arceuthobium tsugense f.sp.

mertensianae

Phytophthora lateralis

Phaeolus schweinitzii

Phaeocryptopus gaumannii

Ionotus tomentosus

Arceuthobium campylopodum

Arceuthobium tsugense f.sp. tsugense

Arceuthobium abietinum f.sp. concoloris

Cronartium ribicola

Adelges piceae

Dendroctonus pseudotsugae

Scolytus unispinosus

Orgyia pseudotsugata

Scolytus ventralis

Malacosoma disstria

Lymantria dispar

Lambdina fiscellaria lugubrasa

Neodiprion tsugae

Marmara arbutiella

Dendroctonus ponderosae

Lambdina fiscellaria

Coloradia pandora

Conophthorus ponderosae

Leucoma salicis

Pissodes sitchensis

Dendroctonus rufipennis

Dendroctonus brevicomis

Choristoneura occidentalis 


\section{APPENDIX B-COUNTIES IN OREGON AND WASHINGTON}

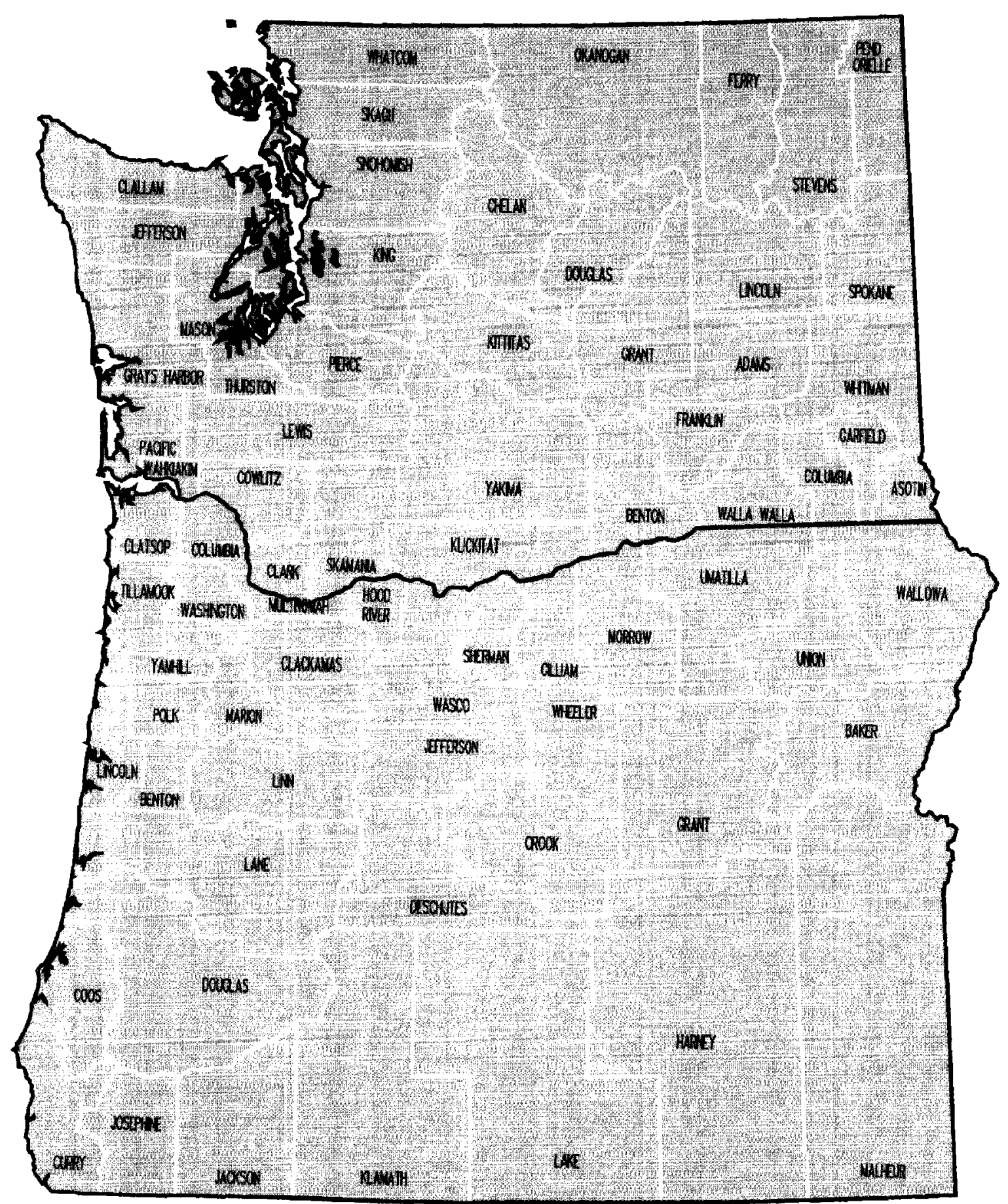




\section{APPENDIX C-1995 COOPERATIVE AERIAL SURVEY RESULTS}

Figure 1 Reporting areas for the 1995 Cooperative Aerial Survey in Oregon and Washington.

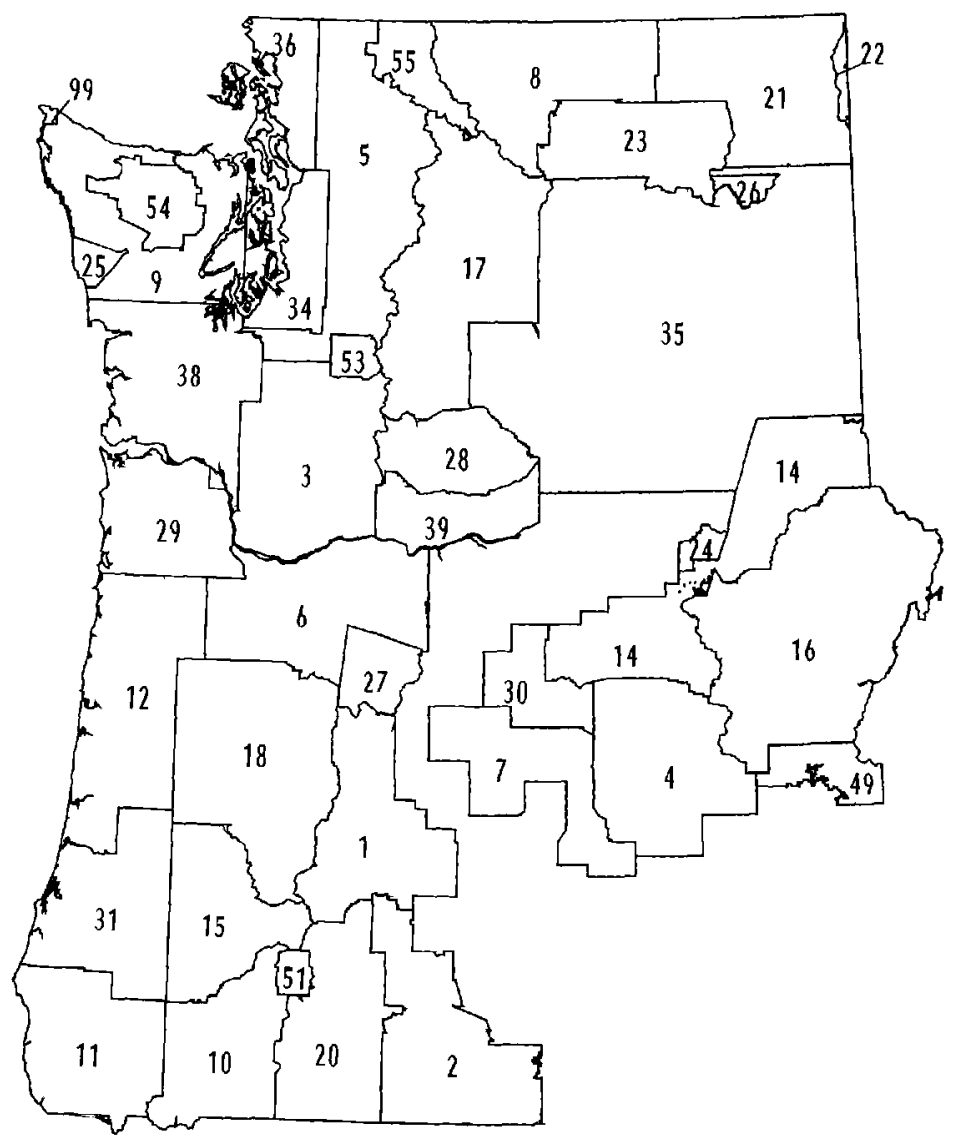

1 Deschutes NF

2 Fremont NF

3 Gifford Pinchot NF

4 Malheur NF

5 Mt. Baker-Snoqualmie NF

6 Mt. Hood NF

7 Ochoco NF

Okanogan NF

Olympic NF

Rogue River NF

Siskiyou NF

Siuslaw NF

4 Umatilla NF

99 Makah IR

\section{Key:}

15 Umpqua NF

16 Wallowa-Whitman NF

17 Wenatchee NF

18 Willamette NF

20 Winema NF

21 Colville NF

22 Kaniksu NF

23 Colville IR

24 Umatilla IR

25 Quinalt IR

26 Spokane IR

27 Warm Springs IR

28 Yakama IR
29 Northwest Oregon

30 Central Oregon

31 Coos-Douglas

34 Puget Sound

35 Northeast Washington

36 Northwest Washington

38 Southwest Washington

39 Glenwood

49 Lookout Mtn.

51 Crater Lake NP

53 Mt. Rainier NP

54 Olympic NP

55 N. Cascades NP

NF:= National Forest

$\mathrm{IR}=$ Indian Reservation

$\mathrm{NP}=$ National Park 
Table L 1995 cooperative aerial survey results, arranged by damage agent and state

\begin{tabular}{|c|c|c|c|}
\hline Insect species-host & State & Acres & \# Trees \\
\hline Area not flown & Oregon & 115682 & 0 \\
\hline Area not flown & Washington & 814274 & 0 \\
\hline Balsam woolly adelgid & Washington & 14380 & 12231 \\
\hline Bear & Oregon & 740 & 755 \\
\hline Bear & Washington & 27225 & 25454 \\
\hline Black pineleaf scale & Oregon & 264 & 0 \\
\hline Blister rust & Washington & 5731 & 0 \\
\hline Budmoth on Douglas-fir & Oregon & 1226 & 0 \\
\hline Cytospora canker & Oregon & 366 & 1466 \\
\hline Douglas-fir beetle & Idaho & 425 & 235 \\
\hline Douglas-fir beetle & Oregon & 37648 & 22004 \\
\hline Douglas-fir beetle & Washington & 6128 & 3917 \\
\hline Douglas-fir beetle engraver & Oregon & 139 & 62 \\
\hline Douglas-fir beetle engraver & Washington & 618 & 355 \\
\hline Douglas-fir tussock moth & Oregon & 2931 & 0 \\
\hline Dying hemlock & Washington & 51 & 0 \\
\hline Fir engraver & Idaho & 14 & 5 \\
\hline Fir engraver & Oregon & 534170 & 429145 \\
\hline Fir engraver & Washington & 39476 & 30323 \\
\hline Fire & Oregon & 1879 & 0 \\
\hline Fire & Washington & 174 & 0 \\
\hline Flatheaded woodborer & Oregon & 3396 & 4533 \\
\hline Larch casebearer & Oregon & 387 & 0 \\
\hline Larch casebearer & Washington & 1434 & 0 \\
\hline Larch needle cast & Washington & 487 & 0 \\
\hline Lodgepole needle cast & Oregon & 387 & 0 \\
\hline Lodgepole needle cast & Washington & 1434 & 0 \\
\hline Maple discoloration & Washington & 484 & 0 \\
\hline Mountain pine beetle, lodgepole pine & Oregon & 104891 & 396346 \\
\hline Mountain pine beetle, lodgepole pine & Washington & 123290 & 346037 \\
\hline Mountain pine beetle, ponderosa pine & Idaho & 14 & 6 \\
\hline Mountain pine beetle, ponderosa pine & Oregon & 128567 & 101666 \\
\hline Mountain pine beetle, ponderosa pine & Washington & 58534 & 52005 \\
\hline Mountain pine beetle, sugar pine & California & 19 & 8 \\
\hline Mountain pine beetle, sugar pine & Oregon & 489 & 275 \\
\hline Mountain pine beetle, w. white pine & Oregon & 424 & 342 \\
\hline Mountain pine beetle, $\mathrm{w}$. white pine & Washington & 16508 & 12047 \\
\hline Mountain pine beetle, whitebark pine & Oregon & 21 & 5 \\
\hline Mountain pine beetle, whitebark pine & Washington & 7541 & 1418 \\
\hline Needleminers on Douglas-fir & Oregon & 7391 & 0 \\
\hline Needleminers on lodgepole pine & Oregon & 6485 & 0 \\
\hline Oregon pine ips & Oregon & 4417 & 3901 \\
\hline Oregon pine ips & Washington & 1275 & 1074 \\
\hline Pacific Madrone decline & Washington & 68 & 0 \\
\hline Port Orford cedar root disease & Oregon & 1885 & 4237 \\
\hline Root disease & Oregon & 1054 & 0 \\
\hline
\end{tabular}

\section{Appendix C -92}




\begin{tabular}{llrr}
\hline Insect species-host & State & Acres & \# Trees \\
\hline Root disease & Washington & 227 & 0 \\
\hline Satin moth & Washington & 4548 & 0 \\
\hline Silver fir beetle & Washington & 762 & 470 \\
\hline Spruce aphid & Oregon & 8 & 0 \\
\hline Spruce aphid & Washington & 841 & 0 \\
\hline Spruce beetle & Oregon & 4874 & 1486 \\
\hline Spruce beetle & Washington & 4679 & 5461 \\
\hline Water & Oregon & 10 & 0 \\
\hline Water & Washington & 1260 & 0 \\
\hline Western balsam bark beetle & Idaho & 23 & 20 \\
\hline Western balsam bark beetle & Oregon & 6858 & 5484 \\
\hline Western balsam bark beetle & Washington & 6423 & 3662 \\
\hline Western pine beetle & Idaho & 221 & 25 \\
\hline Western pine beetle & Oregon & 34100 & 18572 \\
\hline Western pine beetle & Washington & 18021 & 8993 \\
\hline Western pine beetle, small trees & Oregon & 1550 & 3395 \\
\hline Western pine beetle, small trees & Washington & 26881 & 15521 \\
\hline Western spruce budworm & Oregon & 14873 & 0 \\
\hline Western spruce budworm & Washington & 175104 & 0 \\
\hline Wind & Washington & 1038 & 0 \\
\hline
\end{tabular}


Table 2-1995 cooperative aerial survey results, for insects only, arranged by state, reporting area, and insect

\begin{tabular}{|c|c|c|c|c|}
\hline State & Reporting Area & Insect species-host & Acres & \# Trees \\
\hline California & Rogue River National Forest & Mountain pine beetle, sugar pine & 19 & 8 \\
\hline Idaho & Wallowa-Whitman National Forest & Douglas-fir beetle & 425 & 235 \\
\hline Idaho & Wallowa-Whitman National Forest & Fir engraver & 14 & 5 \\
\hline Idaho & Wallowa-Whitman National Forest & Mountain pine beetle, ponderosa pine & 14 & 6 \\
\hline Idaho & Wallowa-Whitman National Forest & Western balsam bark beetle & 23 & 20 \\
\hline Idaho & Wallowa-Whitman National Forest & Western pine beetle & 221 & 25 \\
\hline Oregon & Central Oregon & Douglas-fir beetle & 295 & 132 \\
\hline Oregon & Central Oregon & Fir engraver & 31 & 15 \\
\hline Oregon & Central Oregon & Mountain pine beetle, ponderosa pine & 1674 & 1199 \\
\hline Oregon & Central Oregon & Oregon pine ips & 1254 & 453 \\
\hline Oregon & Central Oregon & Western pine beetle & 12 & 5 \\
\hline Oregon & Coos-Douglas & Douglas-fir beetle & 81 & 70 \\
\hline Oregon & Coos-Douglas & Fir engraver & 61 & 125 \\
\hline Oregon & Coos-Douglas & Flatheaded woodborer & 8 & 10 \\
\hline Oregon & Coos-Douglas & Mountain pine beetle, ponderosa pine & 7 & 10 \\
\hline Oregon & Coos-Douglas & Mountain pine beetle, sugar pine & 15 & 16 \\
\hline Oregon & Crater Lake National Park & Douglas-fir beetle & 135 & 50 \\
\hline Oregon & Crater Lake National Park & Fir engraver & 1243 & 368 \\
\hline Oregon & Crater Lake National Park & Mountain pine beetle, lodgepole pine & 440 & 286 \\
\hline Oregon & Deschutes National Forest & Douglas-fir beetle & 40 & 37 \\
\hline Oregon & Deschutes National Forest & Fir engraver & 17639 & 29054 \\
\hline Oregon & Deschutes National Forest & Mountain pine beetle, lodgepole pine & 77747 & 322592 \\
\hline Oregon & Deschutes National Forest & Mountain pine beetle, ponderosa pine & 7237 & 6489 \\
\hline Oregon & Deschutes National Forest & Mountain pine beetle, w. white pine & 42 & 100 \\
\hline Oregon & Deschutes National Forest & Western pine beetle & 1097 & 530 \\
\hline Oregon & Fremont National Forest & Douglas-fir beetle & 6 & 5 \\
\hline Oregon & Fremont National Forest & Fir engraver & 311424 & 267409 \\
\hline Oregon & Fremont National Forest & Mountain pine beetle, lodgepole pine & 7906 & 40192 \\
\hline Oregon & Fremont National Forest & Mountain pine beetle, ponderosa pine & 21592 & 12539 \\
\hline Oregon & Fremont National Forest & Needleminers on lodgepole pine & 5863 & 0 \\
\hline Oregon & Fremont National Forest & Western pine beetle & 7527 & 5511 \\
\hline Oregon & Malheur National Forest & Douglas-fir beetle & 826 & 889 \\
\hline Oregon & Malheur National Forest & Douglas-fir tussock moth & 2931 & 0 \\
\hline Oregon & Malheur National Forest & Fir engraver & 2916 & 2053 \\
\hline Oregon & Malheur National Forest & Mountain pine beetle, lodgepole pine & 2258 & 1238 \\
\hline Oregon & Malheur National Forest & Mountain pine beetle, ponderosa pine & 7314 & 8930 \\
\hline Oregon & Malheur National Forest & Oregon pine ips & 163 & 155 \\
\hline Oregon & Malheur National Forest & Spruce beetle & 87 & 50 \\
\hline Oregon & Malheur National Forest & Western pine beetle & 2149 & 2405 \\
\hline Oregon & Mt. Hood National Forest & Douglas-fir beetle & 424 & 351 \\
\hline Oregon & Mt. Hood National Forest & Douglas-fir beetle engraver & 8 & 5 \\
\hline Oregon & Mt. Hood National Forest & Fir engraver & 10299 & 8647 \\
\hline Oregon & Mt. Hood National Forest & Mountain pine beetle, lodgepole pine & 221 & 235 \\
\hline Oregon & Mt. Hood National Forest & Mountain pine beetle, ponderosa pine & 10435 & 8359 \\
\hline Oregon & Mt. Hood National Forest & Mountain pine beetle, w. white pine & 228 & 120 \\
\hline Oregon & Mt. Hood National Forest & Oregon pine ips & 114 & 150 \\
\hline
\end{tabular}




\begin{tabular}{|c|c|c|c|c|}
\hline State & Reporting Area & Insect species-host & Acres & \# Trees \\
\hline Oregon & Mt. Hood National Forest & Western pine beetle & 462 & 315 \\
\hline Oregon & Mt. Hood National Forest & Western pine beetle, small trees & 46 & 30 \\
\hline Oregon & Mt. Hood National Forest & Western spruce budworm & 14873 & 0 \\
\hline Oregon & Northwest Oregon & Douglas-fir beetle & 263 & 319 \\
\hline Oregon & Northwest Oregon & Fir engraver & 82 & 55 \\
\hline Oregon & Northwest Oregon & Spruce aphid & 8 & 0 \\
\hline Oregon & Ochoco National Forest & Douglas-fir beetle & 1812 & 3179 \\
\hline Oregon & Ochoco National Forest & Fir engraver & 7041 & 3047 \\
\hline Oregon & Ochoco National Forest & Mountain pine beetle, ponderosa pine & 26806 & 18466 \\
\hline Oregon & Ochoco National Forest & Oregon pine ips & 433 & 225 \\
\hline Oregon & Ochoco National Forest & Western pine beetle & 12254 & 4644 \\
\hline Oregon & Ochoco National Forest & Western pine beetle, small trees & 353 & 376 \\
\hline Oregon & Rogue River National Forest & Douglas-fir beetle & 54 & 55 \\
\hline Oregon & Rogue River National Forest & Fir engraver & 60398 & 44079 \\
\hline Oregon & Rogue River National Forest & Flatheaded woodborer & 3309 & 4463 \\
\hline Oregon & Rogue River National Forest & Mountain pine beetle, lodgepole pine & 290 & 673 \\
\hline Oregon & Rogue River National Forest & Mountain pine beetle, ponderosa pine & 3134 & 3078 \\
\hline Oregon & Rogue River National Forest & Mountain pine beetle, sugar pine & 248 & 119 \\
\hline Oregon & Rogue River National Forest & Mountain pine beetle, w. white pine & 14 & 10 \\
\hline Oregon & Rogue River National Forest & Mountain pine beetle, whitebark pine & 21 & 5 \\
\hline Oregon & Rogue River National Forest & Oregon pine ips & 713 & 1755 \\
\hline Oregon & Rogue River National Forest & Western pine beetle & 3734 & 2946 \\
\hline Oregon & Rogue River National Forest & Western pine beetle, small trees & 1077 & 2914 \\
\hline Oregon & Siskiyou National Forest & Douglas-fir beetle & 37 & 69 \\
\hline Oregon & Siskiyou National Forest & Fir engraver & 2555 & 1590 \\
\hline Oregon & Siskiyou National Forest & Flatheaded woodborer & 79 & 60 \\
\hline Oregon & Siskiyou National Forest & Mountain pine beetle, ponderosa pine & 143 & 160 \\
\hline Oregon & Siskiyou National Forest & Mountain pine beetle, sugar pine & 186 & 120 \\
\hline Oregon & Siskiyou National Forest & Oregon pine ips & 12 & 35 \\
\hline Oregon & Siskiyou National Forest & Western pine beetle & 1063 & 775 \\
\hline Oregon & Siskiyou National Forest & Western pine beetle, small trees & 74 & 75 \\
\hline Oregon & Siuslaw National Forest & Budmoth on Douglas-fir & 1226 & 0 \\
\hline Oregon & Siuslaw National Forest & Douglas-fir beetle & 138 & 205 \\
\hline Oregon & Umatilla National Forest & Douglas-fir beetle & 19045 & 8455 \\
\hline Oregon & Umatilla National Forest & Fir engraver & 3632 & 1959 \\
\hline Oregon & Umatilla National Forest & Mountain pine beetle, ponderosa pine & 7712 & 7557 \\
\hline Oregon & Umatilla National Forest & Needleminers on Douglas-fir & 2580 & 0 \\
\hline Oregon & Umatilla National Forest & Oregon pine ips & 1507 & 988 \\
\hline Oregon & Umatilla National Forest & Spruce beetle & 59 & 25 \\
\hline Oregon & Umatilla National Forest & Western balsam bark beetle & 5003 & 3352 \\
\hline Oregon & Umatilla National Forest & Western pine beetle & 2222 & 429 \\
\hline Oregon & Umatilla Indian Reservation & Douglas-fir beetle & 558 & 223 \\
\hline Oregon & Umatilla Indian Reservation & Fir engraver & 40 & 25 \\
\hline Oregon & Umatilla Indian Reservation & Mountain pine beetle, ponderosa pine & 345 & 540 \\
\hline Oregon & Umatilla Indian Reservation & Western pine beetle & 147 & 25 \\
\hline Oregon & Umpqua National Forest & Douglas-fir beetle & 115 & 110 \\
\hline Oregon & Umpqua National Forest & Fir engraver & 146 & 119 \\
\hline Oregon & Umpqua National Forest & Mountain pine beetle, lodgepole pine & 135 & 115 \\
\hline
\end{tabular}




\begin{tabular}{|c|c|c|c|c|}
\hline State & Reporting Area & Insect species-host & Acres & \# Trees \\
\hline Oregon & Umpqua National Forest & Mountain pine beetle, sugar pine & 35 & 19 \\
\hline Oregon & Umpqua National Forest & Mountain pine beetle, w. white pine & 13 & 10 \\
\hline Oregon & Umpqua National Forest & Western pine beetle & 11 & 10 \\
\hline Oregon & Wallowa-Whitman National Forest & Douglas-fir beetle & 12876 & 7207 \\
\hline Oregon & Wallowa-Whitman National Forest & Douglas-fir beetle engraver & 9 & 7 \\
\hline Oregon & Wallowa-Whitman National Forest & Fir engraver & 3279 & 1594 \\
\hline Oregon & Wallowa-Whitman National Forest & Larch casebearer & 387 & 0 \\
\hline Oregon & Wallowa-Whitman National Forest & Lodgepole needle cast & 387 & 0 \\
\hline Oregon & Wallowa-Whitman National Forest & Mountain pine beetle, lodgepole pine & 278 & 151 \\
\hline Oregon & Wallowa-Whitman National Forest & Mountain pine beetle, ponderosa pine & 14645 & 20169 \\
\hline Oregon & Wallowa-Whitman National Forest & Mountain pine beetle, w. white pine & 12 & 5 \\
\hline Oregon & Wallowa-Whitman National Forest & Needleminers on Douglas-fir & 4811 & 0 \\
\hline Oregon & Wallowa-Whitman National Forest & Oregon pine ips & 185 & 30 \\
\hline Oregon & Wallowa-Whitman National Forest & Spruce beetle & 4728 & 1411 \\
\hline Oregon & Wallowa-Whitman National Forest & Western balsam bark beetle & 1855 & 2132 \\
\hline Oregon & Wallowa-Whitman National Forest & Western pine beetle & 2432 & 566 \\
\hline Oregon & Warm Springs Indian Reservation & Douglas-fir beetle & 263 & 123 \\
\hline Oregon & Warm Springs Indian Reservation & Fir engraver & 4480 & 3946 \\
\hline Oregon & Warm Springs Indian Reservation & Mountain pine beetle, lodgepole pine & 12190 & 28219 \\
\hline Oregon & Warm Springs Indian Reservation & Mountain pine beetle, ponderosa pine & 740 & 471 \\
\hline Oregon & Warm Springs Indian Reservation & Mountain pine beetle, w. white pine & 5 & 5 \\
\hline Oregon & Warm Springs Indian Reservation & Oregon pine ips & 32 & 90 \\
\hline Oregon & Warm Springs Indian Reservation & Western pine beetle & 134 & 40 \\
\hline Oregon & Willamette National Forest & Douglas-fir beetle & 469 & 495 \\
\hline Oregon & Willamette National Forest & Douglas-fir beetle engraver & 122 & 50 \\
\hline Oregon & Willamette National Forest & Fir engraver & 1016 & 770 \\
\hline Oregon & Willamette National Forest & Mountain pine beetle, lodgepole pine & 2225 & 1271 \\
\hline Oregon & Willamette National Forest & Mountain pine beetle, w. white pine & 93 & 87 \\
\hline Oregon & Willamette National Forest & Oregon pine ips & 4 & 20 \\
\hline Oregon & Willamette National Forest & Western pine beetle & 8 & 5 \\
\hline Oregon & Winema National Forest & Black pineleaf scale & 264 & 0 \\
\hline Oregon & Winema National Forest & Douglas-fir beetle & 211 & 30 \\
\hline Oregon & Winema National Forest & Fir engraver & 107888 & 64290 \\
\hline Oregon & Winema National Forest & Mountain pine beetle, lodgepole pine & 1201 & 1374 \\
\hline Oregon & Winema National Forest & Mountain pine beetle, ponderosa pine & 26783 & 13699 \\
\hline Oregon & Winema National Forest & Mountain pine beetle, sugar pine & 5 & 1 \\
\hline Oregon & Winema National Forest & Mountain pine beetle, w. white pine & 17 & 5 \\
\hline Oregon & Winema National Forest & Needleminers on lodgepole pine & 622 & 0 \\
\hline Oregon & Winema National Forest & Western pine beetle & 848 & 366 \\
\hline Washington & Colville National Forest & Douglas-fir beetle & 207 & 120 \\
\hline Washington & Colville National Forest & Douglas-fir beetle engraver & 242 & 165 \\
\hline Washington & Colville National Forest & Fir engraver & 7194 & 5213 \\
\hline Washington & Colville National Forest & Larch casebearer & 616 & 0 \\
\hline Washington & Colville National Forest & Lodgepole needle cast & 616 & 0 \\
\hline Washington & Colville National Forest & Mountain pine beetle, lodgepole pine & 18527 & 18734 \\
\hline Washington & Colville National Forest & Mountain pine beetle, ponderosa pine & 11984 & 8837 \\
\hline Washington & Colville National Forest & Mountain pine beetle, w. white pine & 1616 & 711 \\
\hline Washington & Colville National Forest & Mountain pine beetle, whitebark pine & 57 & 50 \\
\hline
\end{tabular}




\begin{tabular}{|c|c|c|c|c|}
\hline State & Reporting Area & Insect species-host & Acres & \# Trees \\
\hline Washington & Colville National Forest & Oregon pine ips & 485 & 289 \\
\hline Washington & Colville National Forest & Satin moth & 643 & 0 \\
\hline Washington & Colville National Forest & Silver fir beetle & 517 & 276 \\
\hline Washington & Colville National Forest & Spruce beetle & 94 & 30 \\
\hline Washington & Colville National Forest & Western balsam bark beetle & 2901 & 1648 \\
\hline Washington & Colville National Forest & Western pine beetle & 3082 & 1286 \\
\hline Washington & Colville National Forest & Western pine beetle, small trees & 779 & 655 \\
\hline Washington & Colville National Forest & Western spruce budworm & 4034 & \\
\hline Washington & Colville Indian Reservation & Douglas-fir beetle & 113 & 55 \\
\hline Washington & Colville Indian Reservation & Douglas-fir beetle engraver & 12 & 10 \\
\hline Washington & Colville Indian Reservation & Fir engraver & 1849 & 1506 \\
\hline Washington & Colville Indian Reservation & Mountain pine beetle, lodgepole pine & 5035 & 6148 \\
\hline Washington & Colville Indian Reservation & Mountain pine beetle, ponderosa pine & 10495 & 9644 \\
\hline Washington & Colville Indian Reservation & Oregon pine ips & 210 & 385 \\
\hline Washington & Colville Indian Reservation & Satin moth & 949 & 0 \\
\hline Washington & Colville Indian Reservation & Silver fir beetle & 182 & 99 \\
\hline Washington & Colville Indian Reservation & Western balsam bark beetle & 146 & 75 \\
\hline Washington & Colville Indian Reservation & Western pine beetle & 3273 & 1538 \\
\hline Washington & Colville Indian Reservation & Western pine beetle, small trees & 632 & 647 \\
\hline Washington & Colville Indian Reservation & budworm & 936 & 0 \\
\hline Washington & Gifford-Pinchot National Forest & Bals & 1995 & 886 \\
\hline Washington & Gifford-Pinchot National Forest & Douglas-fir beetle & 846 & 534 \\
\hline Washington & Gifford-Pinchot National Forest & Fir engraver & 1168 & 536 \\
\hline Washington & Gifford-Pinchot National Forest & Mountain pine beetle, lodgepole pine & 7 & 5 \\
\hline Washington & Gifford-Pinchot National Forest & Mountain pine beetle, ponderosa pine & 48 & 35 \\
\hline Washington & Gifford-Pinchot National Forest & Mountain pine beetle, w. white pine & 145 & 70 \\
\hline Washington & Gifford-Pinchot National Forest & Mountain pine beetle, whitebark pine & 302 & 4 \\
\hline Washington & Gifford-Pinchot National Forest & Oregon pine ips & 61 & 10 \\
\hline Washington & Gifford-Pinchot National Forest & Silver fir beetle & 37 & 75 \\
\hline Washington & Gifford-Pinchot National Forest & Western balsam bark beetle & 196 & 40 \\
\hline Washington & Gifford-Pinchot National Forest & Western pine beetle & 28 & 30 \\
\hline Washington & Gifford-Pinchot National Forest & Western spruce budworm & 15407 & 0 \\
\hline Washington & Glenwood & Douglas-fir beetle & 434 & 115 \\
\hline Washington & Glenwood & Fir engraver & 312 & 315 \\
\hline Washington & Glenwood & Mountain pine beetle, ponderosa pine & 5454 & 5184 \\
\hline Washington & Glenwood & Oregon pine ips & 237 & 130 \\
\hline Washington & Glenwood & Spruce beetle & 39 & 2 \\
\hline Washington & Glenwood & Western pine beetle & 2067 & 911 \\
\hline Washington & Glenwood & Western pine beetle, small trees & 19187 & 9051 \\
\hline Washington & Glenwood & Western spruce budworm & 29028 & 0 \\
\hline Washington & Kaniksu National Forest & Douglas-fir beetle & 30 & 15 \\
\hline Washington & Kaniksu National Forest & Fir engraver & 1963 & 1431 \\
\hline Washington & Kaniksu National Forest & Larch casebearer & 120 & 0 \\
\hline Washington & Kaniksu National Forest & Lodgepole needle cast & 120 & 0 \\
\hline Washington & Kaniksu National Forest & Mountain pine beetle, lodgepole pine & 2299 & 2174 \\
\hline Washington & Kaniksu National Forest & Mountain pine beetle, ponderosa pine & 718 & 551 \\
\hline Washington & Kaniksu National Forest & Mountain pine beetle, w. white pine & 3258 & 3907 \\
\hline Washington & Kaniksu National Forest & Spruce beetle & 77 & \\
\hline
\end{tabular}




\begin{tabular}{|c|c|c|c|c|}
\hline State & Reporting Area & Insect species-host & Acres & \# Trees \\
\hline Washington & Kaniksu National Forest & Western balsam bark beetle & 124 & 150 \\
\hline Washington & Kaniksu National Forest & Western pine beetle & 31 & 20 \\
\hline Washington & Makah Indian Reservation & Douglas-fir beetle & 8 & 5 \\
\hline Washington & Mt. Baker-Snoqualmie National Forest & Balsam woolly adelgid & 3975 & 3314 \\
\hline Washington & Mt. Baker-Snoqualmie National Forest & Douglas-fir beetle & 1050 & 581 \\
\hline Washington & Mt. Baker-Snoqualmie National Forest & Douglas-fir beetle engraver & 137 & 35 \\
\hline Washington & Mt. Baker-Snoqualmie National Forest & Fir engraver & 347 & 174 \\
\hline Washington & Mt. Baker-Snoqualmie National Forest & Mountain pine beetle, lodgepole pine & 332 & 1534 \\
\hline Washington & Mt. Baker-Snoqualmie National Forest & Mountain pine beetle, Ponderosa pine & 209 & 125 \\
\hline Washington & Mt. Baker-Snoqualmie National Forest & Mountain pine beetle, $\mathrm{w}$. white pine & 454 & 260 \\
\hline Washington & Mt. Baker-Snoqualmie National Forest & Mountain pine beetle, whitebark pine & 59 & 85 \\
\hline Washington & Mt. Baker-Snoqualmie National Forest & Silver fir beetle & 26 & 20 \\
\hline Washington & Mt. Baker-Snoqualmie National Forest & Spruce beetle & 2336 & 4506 \\
\hline Washington & Mt. Baker-Snoqualmie National Forest & Western balsam bark beetle & 150 & 115 \\
\hline Washington & Mt. Baker-Snoqualmie National Forest & Western pine beetle & 332 & 270 \\
\hline Washington & Mt. Rainier National Park & Balsam woolly adelgid & 2880 & 3600 \\
\hline Washington & North Cascades National Park & Balsam woolly adelgid & 57 & 80 \\
\hline Washington & North Cascades National Park & Douglas-fir beetle & 54 & 60 \\
\hline Washington & North Cascades National Park & Fir engraver & 447 & 235 \\
\hline Washington & North Cascades National Park & Larch needle cast & 59 & 0 \\
\hline Washington & North Cascades National Park & Mountain pine beetle, lodgepole pine & 69 & 150 \\
\hline Washington & North Cascades National Park & Mountain pine beetle, ponderosa pine & 258 & 220 \\
\hline Washington & North Cascades National Park & Mountain pine beetle, w. white pine & 274 & 155 \\
\hline Washington & North Cascades National Park & Mountain pine beetle, whitebark pine & 48 & 34 \\
\hline Washington & North Cascades National Park & Spruce beetle & 99 & 55 \\
\hline Washington & North Cascades National Park & Western balsam bark beetle & 80 & 80 \\
\hline Washington & North Cascades National Park & Western pine beetle & 160 & 75 \\
\hline Washington & Northeast Washington & Douglas-fir beetle & 91 & 90 \\
\hline Washington & Northeast Washington & Douglas-fir beetle engraver & 61 & 65 \\
\hline Washington & Northeast Washington & Fir engraver & 5887 & 7251 \\
\hline Washington & Northeast Washington & Larch casebearer & 698 & 0 \\
\hline Washington & Northeast Washington & Lodgepole needle cast & 698 & 0 \\
\hline Washington & Northeast Washington & Mountain pine beetle, lodgepole pine & 611 & 430 \\
\hline Washington & Northeast Washington & Mountain pine beetle, ponderosa pine & 9842 & 10687 \\
\hline Washington & Northeast Washington & Mountain pine beetle, w. white pine & 118 & 75 \\
\hline Washington & Northeast Washington & Oregon pine ips & 129 & 125 \\
\hline Washington & Northeast Washington & Satin moth & 20 & 0 \\
\hline Washington & Northeast Washington & Western pine beetle & 1270 & 821 \\
\hline Washington & Northeast Washington & Western pine beetle, small trees & 580 & 725 \\
\hline Washington & Nortwest Washington & Douglas-fir beetle & 367 & 292 \\
\hline Washington & Nortwest Washington & Douglas-fir beetle engraver & 36 & 10 \\
\hline Washington & Nortwest Washington & Mountain pine beetle, lodgepole pine & 90 & 159 \\
\hline Washington & Okanogan National Forest & Douglas-fir beetle & 213 & 110 \\
\hline Washington & Okanogan National Forest & Douglas-fir beetle engraver & 127 & 65 \\
\hline Washington & Okanogan National Forest & Fir engraver & 2656 & 1373 \\
\hline Washington & Okanogan National Forest & Mountain pine beetle, lodgepole pine & 90138 & 310023 \\
\hline Washington & Okanogan National Forest & Mountain pine beetle, ponderosa pine & 5618 & 4701 \\
\hline Washington & Okanogan National Forest & Mountain pine beetle, w. white pine & 1295 & 820 \\
\hline
\end{tabular}




\begin{tabular}{|c|c|c|c|c|}
\hline State & Reporting Area & Insect species-host & Acres & \# Trees \\
\hline Washington & Okanogan National Forest & Mountain pine beetle, whitebark pine & 901 & 390 \\
\hline Washington & Okanogan National Forest & Oregon pine ips & 55 & 30 \\
\hline Washington & Okanogan National Forest & Satin moth & 2273 & 0 \\
\hline Washington & Okanogan National Forest & Spruce aphid & 33 & 0 \\
\hline Washington & Okanogan National Forest & Spruce beetle & 876 & 435 \\
\hline Washington & Okanogan National Forest & Western balsam bark beetle & 1228 & 600 \\
\hline Washington & Okanogan National Forest & Western pine beetle & 1560 & 597 \\
\hline Washington & Okanogan National Forest & Western pine beetle, small trees & 30 & 30 \\
\hline Washington & Olympic National Forest & Balsam woolly adelgid & 482 & 335 \\
\hline Washington & Olympic National Forest & Douglas-fir beetle & 488 & 308 \\
\hline Washington & Olympic National Forest & Fir engraver & 34 & 21 \\
\hline Washington & Olympic National Forest & Mountain pine beetle, lodgepole pine & 64 & 35 \\
\hline Washington & Olympic National Forest & Mountain pine beetle, w. white pine & 339 & 225 \\
\hline Washington & Olympic National Forest & Spruce aphid & 83 & 0 \\
\hline Washington & Olympic National Park & Balsam woolly adelgid & 3400 & 3110 \\
\hline Washington & Olympic National Park & Douglas-fir beetle & 34 & 25 \\
\hline Washington & Olympic National Park & Fir engraver & 26 & 14 \\
\hline Washington & Olympic National Park & Mountain pine beetle, $\mathrm{w}$. white pine & 1192 & 755 \\
\hline Washington & Olympic National Park & Mountain pine beetle, whitebark pine & 38 & 20 \\
\hline Washington & Puget Sound & Douglas-fir beetle & 253 & 195 \\
\hline Washington & Puget Sound & Douglas-fir beetle engraver & 3 & 5 \\
\hline Washington & Puget Sound & Mountain pine beetle, w. white pine & 28 & 10 \\
\hline Washington & Quinalt Indian Reservation & Fir engraver & 36 & 25 \\
\hline Washington & Southwest Washington & Douglas-fir beetle & 210 & 171 \\
\hline Washington & Southwest Washington & Mountain pine beetle, lodgepole pine & 12 & 20 \\
\hline Washington & Southwest Washington & Spruce aphid & 725 & 0 \\
\hline Washington & Spokane Indian Reservation & Douglas-fir beetle & 105 & 90 \\
\hline Washington & Spokane Indian Reservation & Fir engraver & 337 & 410 \\
\hline Washington & Spokane Indian Reservation & Mountain pine beetle, lodgepole pine & 13 & 10 \\
\hline Washington & Spokane Indian Reservation & Mountain pine beetle, ponderosa pine & 1103 & 1416 \\
\hline Washington & Spokane Indian Reservation & Oregon pine ips & 6 & 5 \\
\hline Washington & Spokane Indian Reservation & Spruce beetle & 21 & 5 \\
\hline Washington & Spokane Indian Reservation & Western pine beetle & 208 & 80 \\
\hline Washington & Spokane Indian Reservation & Western pine beetle, small trees & 174 & 230 \\
\hline Washington & Umatilla National Forest & Douglas-fir beetle & 791 & 490 \\
\hline Washington & Umatilla National Forest & Fir engraver & 1812 & 1606 \\
\hline Washington & Umatilla National Forest & Mountain pine beetle, lodgepole pine & 55 & 120 \\
\hline Washington & Umatilla National Forest & Mountain pine beetle, ponderosa pine & 1472 & 2152 \\
\hline Washington & Umatilla National Forest & Oregon pine ips & 45 & 25 \\
\hline Washington & Umatilla National Forest & Spruce beetle & 22 & 5 \\
\hline Washington & Umatilla National Forest & Western balsam bark beetle & 438 & 370 \\
\hline Washington & Umatilla National Forest & Western pine beetle & 455 & 145 \\
\hline Washington & Wenatchee National Forest & Balsam woolly adelgid & 1582 & 901 \\
\hline Washington & Wenatchee National Forest & Douglas-fir beetle & 812 & 646 \\
\hline Washington & Wenatchee National Forest & Fir engraver & 14706 & 8583 \\
\hline Washington & Wenatchee National Forest & Larch needle cast & 428 & 0 \\
\hline Washington & Wenatchee National Forest & Mountain pine beetle, lodgepole pine & 1574 & 1789 \\
\hline Washington & Wenatchee National Forest & Mountain pine beetle, ponderosa pine & 7418 & 6390 \\
\hline
\end{tabular}




\begin{tabular}{lllrr}
\hline State & Reporting Area & Insect species-host & Acres & \# Trees \\
\hline Washington & Wenatchee National Forest & Mountain pine beetle, w. white pine & 7746 & 4964 \\
\hline Washington & Wenatchee National Forest & Mountain pine beetle, whitebark pine & 5327 & 760 \\
\hline Washington & Wenatchee National Forest & Oregon pine ips & 47 & 75 \\
\hline Washington & Wenatchee National Forest & Satin moth & 646 & 325 \\
\hline Washington & Wenatchee National Forest & Spruce beetle & 1160 & 584 \\
\hline Washington & Wenatchee National Forest & Western balsam bark beetle & 4805 & 2810 \\
\hline Washington & Wenatchee National Forest & Western pine beetle & 3525 & 2678 \\
\hline Washington & Wenatchee National Forest & Western pine beetle, small trees & 132 & 0 \\
\hline Washington & Wenatchee National Forest & Western spruce budworm & 9 & 5 \\
\hline Washington & Yakima Indian Reservation & Balsam woolly adelgid & 702 & 1630 \\
\hline Washington & Yakima Indian Reservation & Douglas-fir beetle & 42 \\
\hline Washington & Yakima Indian Reservation & Fir engraver & 4764 \\
\hline Washington & Yakima Indian Reservation & Mountain pine beetle, lodgepole pine & 4706 \\
\hline Washington & Yakima Indian Reservation & Mountain pine beetle, Ponderosa pine & 3915 & 2063 \\
\hline Washington & Yakima Indian Reservation & Mountain pine beetle, w. white pine & 43 & 95 \\
\hline Washington & Yakima Indian Reservation & Mountain pine beetle, whitebark pine & 809 & 75 \\
\hline Washington & Yakima Indian Reservation & Spruce beetle & 469 & 78 \\
\hline Washington & Yakima Indian Reservation & Western pine beetle & 750 & 410 \\
\hline Washington & Yakima Indian Reservation & Western pine beetle, small trees & 1974 & 1505 \\
\hline Washington & Yakima Indian Reservation & Western spruce budworm & 125567 & 0 \\
\hline
\end{tabular}

\section{Appendix C-100}




\section{APPENDIX D-THE NATIONAL FOREST HEALTH MONITORING PROGRAM}

The national Forest Health Monitoring Program (often abbreviated as FHM) began in 1990 in 10 northeastern states. It was a cooperative effort between the USDA Forest Service, the U.S. Environmental Protection Agency (EPA), state forestry agencies, and the National Association of State Foresters. Today, cooperators also include the U.S. Department of the Interior's Bureau of Land Management, Fish and Wildlife Service, and National Park Service; the USDA National Resource Conservation Service; and state forestry organizations in eight additional states. The main objectives of this program are to determine the status, trends, and condition of forests nationwide.

The national Forest Health Monitoring West Coast Administrative Region includes California, Hawaii, and Alaska plus Oregon and Washington. Operational field work began in California in 1992 when 55 forested plots were measured across the state. A different set of about 50 forested plots were measured yearly from 1993 to 1995 . This complete 4-year set of data comprises the baseline condition for California forests. Each baseline year is a separate estimate of forest conditions in the state. Remeasurement of California plots began in 1996. Another field effort in the West Coast region was a pilot study for western Oregon and Washington (described in chapter 5), in which 25 plots in Douglas-fir habitat were measured. Baseline plots in Oregon and Washington will be established in 1997.

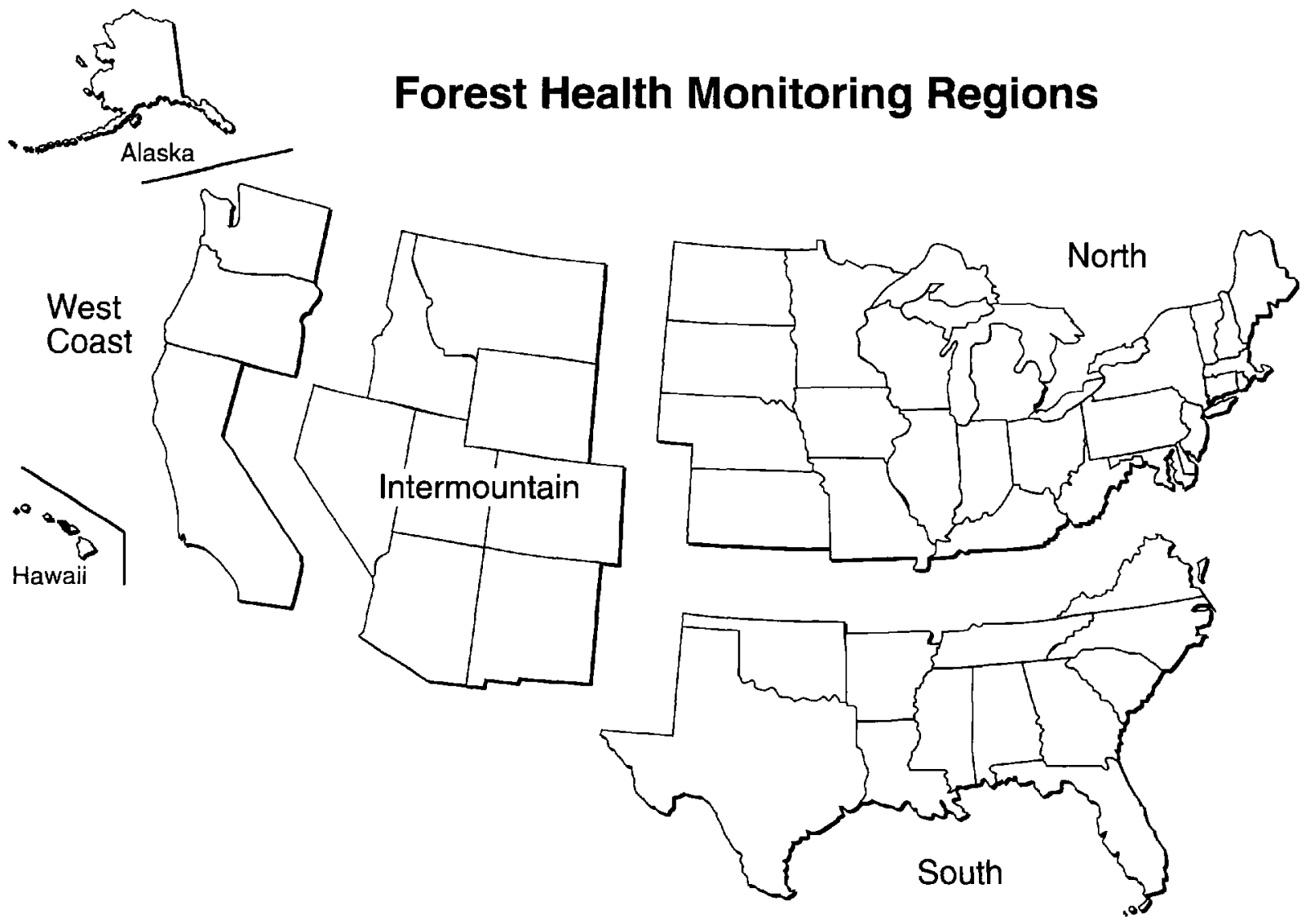


Three separate but parallel activities comprise the Forest Health Monitoring Program. In detection monitoring, field crews measure selected biotic and abiotic features called indicators of forest condition during a baseline period. These same features are then remeasured at yearly or other intervals. Changes between the baseline and remeasurement conditions indicate a response to natural forest change or ecosystem disturbance. The ecosystem indicators are analogous to general blood pressure, pulse, and blood chemistry data recorded for people in routine medical exams. Infant, juvenile, adult, and mature age groups have certain indicator values for normal health. Values outside the normal ranges indicate something is amiss and should be checked by a medical specialist.

Evaluation monitoring begins when the cause of a significant and detected change is unknown. Activities include intensive field sampling and combined interpretations by ecologists, entomologists, hydrologists, pathologists, silviculturists, and others. These resource specialists are like the heart, kidney, lung, and other medical experts who are asked to diagnose blood chemistry results that fall outside of normal values or that result from traumatic injury.

Intensive site ecosystem monitoring combines knowledge from evaluation monitoring and results from long-term watershed-scale research at a few sites with diverse forest types and biomes typical of those found in the United States. The best example in the West is the H.J. Andrews Experimental Forest near Blue River, Oregon, where forest research work has been conducted since the 1940s.

Combining information from all three monitoring activities allows predicting where and how future ecosystem changes might take place under given environmental and management conditions. 
Index

\section{A}

air pollution 11, 19-21, 30, $46,72,75-76,82,84,85$ air quality. See air pollution Alaska yellow-cedar 39, 88 American elm 62, 88 annosus root disease 29, $36,38,53-54,89$ armillaria root disease 27 , $32,36,40,54,83,89$

B

balsam woolly adelgid 16 , 32 , 50-51, 89, 92, 97100

bark beetles 10,12-14,26, $32-33,35-38,40,42-43$, $47-48,51,54,56-58,62$, $79-81,85$

basal area 69

bear damage $22,28-29$

bigleaf maple $25,30,45,51$, 88

bird community index. See songbird habitat

bioindicators. See indicators black cottonwood 30,33 , 38,88

black stain root disease 27 , $40,83,89$

Blue Mountains 4, 13, 15, 33-38

C

California black oak 39,88

canker diseases 31,34

chinkapin 39, 88

crown dieback 70-71

defoliators $10,32-33,35$, 49-50, 54-55, 58, 62-64, 82 detection monitoring 102

Douglas-fir 7, 9-10, 25-29, 33-36, 38-39, 43, 45, 47-49, 53-56, 67, 69, 82,88

Douglas-fir beetle 26, 35-36, $43,47-48,56,89,92$, 94-100

Douglas-fir dwarf mistletoe 34-35, 40-41, 55-56, 89

Douglas-fir engraver 89

Douglas-fir tussock moth $38,79,82,89,92,94$

drought $11,15,26,30-37$, $39,42-43,47,51-52,56$, $58,64,79-80,82,84$

dwarf mistletoes $10,29,34$ $35,40-41,49,55-56$

E

Eastern Cascades 4, 79-82

Eastern Cascades, Oregon 4, 33-38

Eastern Cascades, Washington $4,53-58$

Engelmann spruce 25, 38, $45,53,88$

exotic pests $16-19,29,32$, 41-43, 50, 52, 58, 62-64, $82,84-85$

$\mathbf{F}$

fir engraver 35-36, 89,92, 94-100

fire 6-12, 25-26, 30, 32-41, $45,51,53-55,58,61$, $76,79-82,84,85,92$

fire suppression $8-10,32-$ $34,36-38,53-55,79,84$

fire exclusion. See fire suppression

floods 34

foliage disease $27-28,32$, 47-49, 52

foliage transparency $70-72$, 77

forest health monitoring 21 $23,66-78,85,101-102$

Forest Health Monitoring Program 22, 66-77,
101-102

forest tent caterpillar 52, 89

G

grand fir 9, 16, 25, 30, 32-

$35,37,50,53-56,88$

grazing $6,9,11,38,57$

gypsy moth $16,19,62-64$, 89

\section{H}

hazard tree $46-47,61,64$ hemlock looper 9, 49-50, 82,89

hemlock sawfly 29,89

hybrid poplar 32,88

\section{I}

indicators $2,19,21,22,66-$ $67,70,73-74,76-77$, 102

Intensive site ecosystem monitoring 102

introduced pests. See exotic pests

$J$

Jeffrey pine $39,41,88$

$\mathrm{K}$

Klamath Mountains 4, 39-43

$\mathbf{L}$

laminated root rot 26-27, $36,40,47,53,61,89$

larch dwarf mistletoe 34, 55,89

lichens 19-22, 30, 46, 68, 75-77

lodgepole pine $6,10-11,25$, $33,35,37-38,40-41,53$, $55,57,80-81,88,92$, 94-100

lodgepole pine dwarf mistletoe $35,40,55,89$

low temperature injury 1415,31 
M

madrone leafminer 52,89

melampsora leaf rust 32,89

mixed conifer 10, 33-37, 43, 53-56, 68, 79

Modoc Plateau 4, 33-38

monitoring. See forest health monitoring

mortality 11-13, 67

mountain hemlock 25, 39, $41,45,49,53,88$

mountain hemlock dwarf mistletoe 41, 49, 89

mountain pine beetle 11 , 37-38, 42-43, 51, 56, 57, $81,89,92,94-100$

$\mathbf{N}$

noble fir $6,25,45,88$

O

Okanogan Highlands 4, 5358

Oregon 24-43

Oregon ash 30, 88

Oregon Coast Range 4, 2529

Oregon white oak 30,32 , $39,64,88$

ozone $19-21,30,46,84$

\section{$\mathbf{P}$}

Pacific dogwood 52, 64, 88

Pacific madrone $39,52,88$

Pacific silver fir $25,39,45$, 88

Pacific yew 25, 88

pandora moth $38,61,89$

poles 68,69

Ponderosa pine $6-7,10,12$, $30-38,41,43,53-58,82$, 88

Ponderosa pine cone beetle 32,89

Port-Orford-cedar 18, 19, $39,41-42,84,88$

Port-Orford-cedar root disease 18, 19, 41-42, 84,89
Puget Trough 4, 45-52

Q

quaking aspen $33,38,39$, $58,80,88$

$\mathbf{R}$

red alder 25, 30, 45, 51, 52, 88

risk rating 23

root disease $10,12,18-19$, 26-27, 29, 32, 35-36, 40-43, 46, 53-54, 56, 58, $61,79-80,82-84,93$

root rot. See root disease

S

sapling crown vigor 69,70 saplings $68-70,72,77$ satin moth $58,89,93,97-$ 100

sawtimber 68, 69, 77

Schweinitzii root and butt rot 54,89

seedlings $68,83-84$

site characteristics 67-69

Sitka spruce $25,29,45,88$

Sitka spruce weevil 29, 89

songbird habitat $67,74,76-$ 77

Southern Cascades 4, 39-43 spruce beetle $38,84-85,89$, 93-100

stand characteristics 68

stem decay 26, 34, 46

Subalpine fir $6,25,45,54$, 88

subplots $68,73-74,77$

sugar pine $17,25,33,39$, 42-43, 84-85, 88, 92, 94-96

Swiss needle cast $27-28,47-$ $49,82,89$

\section{T}

true fir. See grand fir and white fir understory vegetation 22 , 68-69, 76

urban forest health $60-65$

V

vegetation change $6-10$

vegetation structure 74,77

\section{W}

Washington 44-58

Washington Coast Range 4, 45-52

weather 13-16, 18, 21, 3334, 52, 60 see also drought, floods, low temperature injury, windthrow, winter wind damage

Western Cascades 4, 82-84

Western Cascades, Oregon 4 , 25-29

Western Cascades, Washington $4,45-52$

western hemlock dwarf mistletoe 49, 89

western larch 10, 12, 33-34, $37,53-55,82$

western pine beetle 35,58 , 89, 93-100

western redcedar $25,28,30$, $45,69,88$

western spruce budworm 11-13, 35, 37, 54-56, 79, $82,89,93,95,97,100$

white fir $33,35-36,39,41$, $43,50,88$,

white fir dwarf mistletoe 34 , 89

white pine blister rust 16 $17,19,29,42,51,84$, 89

whitebark pine $17,25,42$, $45,51,53,85,88$

Willamette Valley 4, 25-29

willow $33,45,88$

windthrow 26-27, 34, 38, $45,47-48,56,61$

winter wind injury 15 


\section{Campbell, Sally; Liegel, Leon, tech. coords. 1996. Disturbance and forest health in Oregon and Washington. Gen. Tech. Rep. PNW- GTR-381. Portland, OR: U.S. Department of Agriculture, Forest Service, Pacific Northwest Research Station and Pacific Northwest Region; Oregon Department of Forestry; and Washington Depart- ment of Natural Resources. 105 p.}

The scope and intensity of disturbance by such agents as fire, insects, diseases, air pollution, and weather in Pacific Northwest forests suggests that forest health has declined in recent years in many areas. The most significant disturbances and causes of tree mortality or decline in Oregon and Washington are presented and illustrated. We discuss the interrelations of disturbance with forest management activities and the effect on native trees and suggest some solutions for reducing the severity of disturbance. One chapter reports on a forest health monitoring pilot project.

The Forest Service of the U.S. Department of Agriculture is dedicated to the principle of multiple use management of the Nation's forest resources for sustained yields of wood, water, forage, wildlife, and recreation. Through forestry research, cooperation with the States and private forest owners, and management of the National Forests and National Grasslands, it strives-as directed by Congress-to provide increasingly greater service to a growing Nation.

The United States Department of Agriculture (USDA) prohibits discrimination in its programs on the basis of race, color, national origin, sex, religion, age, disability, political beliefs, and marital or familial status. (Not all prohibited bases apply to all programs.) Persons with disabilities who require alternative means of communication of program information (Braille, large print, audiotape, etc.) should contact the USDA Office of Communications at (202) 720-2791.

To file a complaint, write the Secretary of Agriculture, U.S. Department of Agriculture, Washington, DC 20250, or call (202) 720-7327 (voice) or (202) 7201127 (TDD). USDA is an equal employment opportunity employer.

Pacific Northwest Research Station

333 S.W. First Avenue

P.O. Box 3890

Portland, Oregon 97208-3890 
s

$$
\begin{aligned}
& x^{2}+1
\end{aligned}
$$

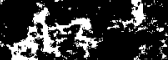

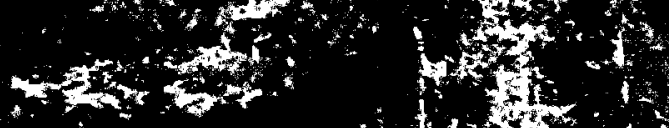

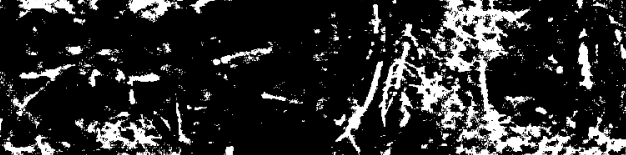

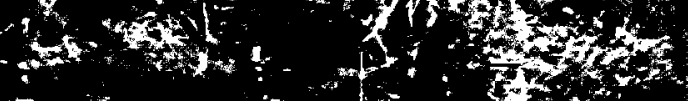

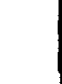

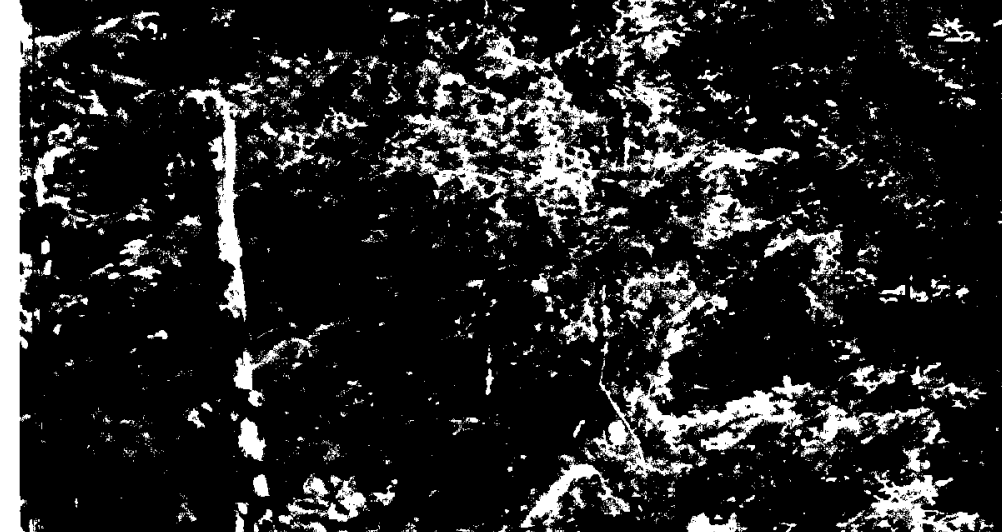

sas.

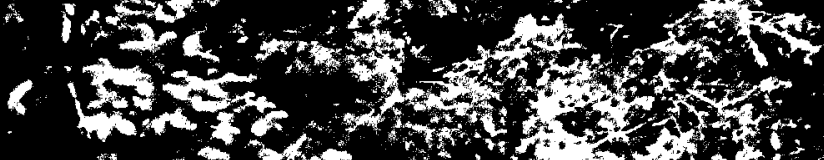

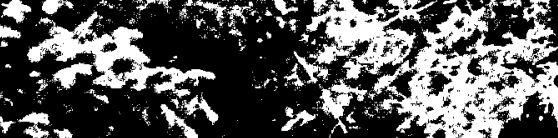

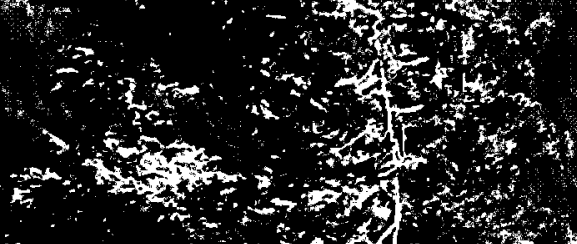

